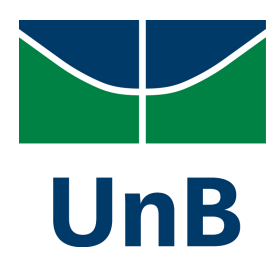

UNIVERSIDADE DE BRASÍLIA

FACULDADE DE DIREITO

PROGRAMA DE PÓS-GRADUAÇÃO EM DIREITO

RODRIGO LEONARDO DE MELO SANTOS

A DISCRIMINAÇÃO DE HOMENS GAYS NA DINÂMICA DAS RELAÇÕES DE EMPREGO:

REFLEXÕES SOB A PERSPECTIVA DO DIREITO

FUNDAMENTAL AO TRABALHO DIGNO 
RODRIGO LEONARDO DE MELO SANTOS

\title{
A DISCRIMINAÇÃO DE HOMENS GAYS NA DINÂMICA DAS RELAÇÕES DE EMPREGO: \\ REFLEXÕES SOB A PERSPECTIVA DO DIREITO FUNDAMENTAL AO TRABALHO DIGNO
}

\begin{abstract}
Dissertação de mestrado apresentada ao Programa de Pós-Graduação em Direito da Universidade de Brasília como requisito parcial para a obtenção do título de Mestre em Direito.
\end{abstract}

Área de Concentração: Direito, Estado e Constituição

Linha de Pesquisa: Internacionalização, Trabalho e Sustentabilidade

Orientadora: Profa . Dra. Gabriela Neves Delgado

Brasília 


\title{
A DISCRIMINAÇÃO DE HOMENS GAYS NA DINÂMICA DAS RELAÇÕES DE EMPREGO: REFLEXÕES SOB A PERSPECTIVA DO DIREITO FUNDAMENTAL AO TRABALHO DIGNO
}

\begin{abstract}
Dissertação de mestrado apresentada ao Programa de Pós-Graduação em Direito da Universidade de Brasília como requisito parcial para a obtenção do título de Mestre em Direito.
\end{abstract}

Aprovada em: Brasília, de de

Banca Examinadora:

Profa. Dra . Gabriela Neves Delgado

Faculdade de Direito/UnB (orientadora e presidente da banca)

Prof. Dr. Pedro Augusto Gravatá Nicoli, Faculdade de Direito/UFMG (membro externo)

Prof. Dr. Menelick de Carvalho Netto

Faculdade de Direito/UnB (membro interno)

Profa. Dra. Suzana Borges Viegas de Lima

Faculdade de Direito/UnB (membro interno) 
Em memória de Lamartine Brito Santos, pelo ensinamento de que, com dedicação e persistência, posso tornar realidade todos os meus sonhos. 


\section{AGRADECIMENTOS}

Ao apresentar meu trabalho de conclusão de curso, ainda em 2013, em que me dediquei ao tema do casamento civil entre pessoas do mesmo sexo, tinha quase certeza de que aquela seria provavelmente a última vez que, num curto espaço de tempo, estaria escrevendo sobre os direitos fundamentais de pessoas homossexuais — talvez por excesso de otimismo causado pela leva de decisões judiciais favoráveis às teses que encampei no trabalho, como o reconhecimento das uniões homoafetivas pelo Supremo Tribunal Federal, em 2011, e, menos de dois anos depois, da possibilidade jurídica do casamento, por parte do Superior Tribunal de Justiça e do Conselho Nacional de Justiça.

Eu estava enganado. A realidade tem me mostrado, nos últimos anos, que ainda há, sim, um longo caminho a trilhar, no Brasil e no mundo, em matéria de reconhecimento social e jurídico não só de gays e lésbicas, mas de toda a população LGBT, principalmente no que toca à eliminação das discriminações. A inércia das instituições estatais, notadamente do Legislativo, em se engajar numa atuação mais incisiva nesse sentido só deixa mais evidente o quão longe esse objetivo ainda está.

O mergulho no mundo do trabalho, pós-faculdade, me fez perceber, aliás, o quanto se tem para escrever, reforçar e reiterar a respeito de algumas formas particulares da discriminação homofóbica, como é o caso da praticada no âmbito das relações de emprego.

Essa foi a motivação que me fez retornar ao tema. E o presente trabalho é a contribuição, anda que mínima, que espero estar prestando a partir das reflexões que desenvolvi, com o auxílio e o incentivo de muitas pessoas, no curso dos últimos dois anos. Nesse passo, não posso deixar de agradecer aos que fizeram parte dessa trajetória e tiveram um papel importante, das mais diversas formas, na composição dessa pesquisa:

A Helena Santos, minha mãe, pela preocupação e pela compreensão pelas noites mal dormidas, que me acompanharam nos momentos finais da elaboração da dissertação, mas igualmente pelo incentivo maternal carinhoso para que eu não titubeasse diante das dificuldades que a pesquisa nos coloca.

Ao Lucas Santos, meu irmão, companheiro de quase toda uma vida, por respeitar os meus momentos de afastamento em que tive de me dedicar ao trabalho 
e também por comparecer, sempre que precisei, de forma solícita, me auxiliando na redação ou na revisão dos escritos.

Ao Gustavo Arcanjo, que segue nesses quase dez anos me ensinando que amor de verdade é, sim, uma coisa única, que não observa sexos nem barreira nenhuma para se realizar. Obrigado por entender minha ausência nesses meses, por estar presente me amparando nos momentos de dificuldade e pela inestimável contribuição que você me prestou na elaboração das tabelas e gráficos que utilizei na dissertação. Te amo, muito.

Aos amigos Marina de Oliveira, Maira Bravo, Marco Antonio Souza, Vinicius Colucci e Jacqueline Marra, por aliviarem minha tensão nos fins de semana com sua presença. Se sumi por uns tempos, foi por um bom motivo. Obrigado, por não desistirem de mim!

Às sempre queridas Aimée Guimarães, Lara Borges e Virna Cruz. A FD não me deu presente melhor que a amizade de vocês. Agradeço imensamente pelo apoio nessa difícil fase que é a Pós-Graduação.

Ao José Dutra Jr., chefe compreensivo que muito me incentivou a concluir esta pesquisa. Obrigado por aliviar a carga de trabalho todas as vezes que precisei, ao longo desse percurso, para que eu pudesse me dedicar à dissertação.

Ao Grupo de Pesquisa "Trabalho, Constituição e Cidadania" (UnB/CNPq), por renovar o meu fôlego para a pesquisa, no curso desse processo, com discussões sempre instigantes. Obrigado especialmente por me ouvirem falar sobre essa pesquisa e me questionarem bastante. Cada crítica ou dúvida levantada foi crucial para a definição dos rumos dessa dissertação.

E, finalmente, à minha eterna Prof ${ }^{a}$. Dra . Gabriela Neves Delgado. Fui agraciado com a melhor orientadora que poderia desejar. Sua doçura e compreensão, aliadas a seu pulso firme e à cobrança de resultados, no processo de orientação, foram a mistura necessária para que essa pesquisa se tornasse o que ela é hoje. Obrigado pelos conselhos, pela paciência, pelo companheirismo e, acima de tudo, pela confiança que depositou em mim. Espero fortemente que essa parceria siga por anos rendendo bons frutos, como tem sido para mim o projeto piloto de Prática Trabalhista e Previdenciária nos Tribunais Superiores. 


\section{RESUMO}

Tendo por referência o direito fundamental ao trabalho digno assentado pela Constituição Federal de 1988, a presente dissertação tem por objetivo investigar as respostas que o Direito do Trabalho brasileiro oferece ao problema da discriminação por orientação sexual na dinâmica das relações de emprego, especialmente a sofrida por trabalhadores gays. Em sua maior parte, a construção dos argumentos foi amparada em pesquisa bibliográfica. A pesquisa partiu de uma contextualização histórica dos preconceitos culturalmente herdados a respeito do homoerotismo, cobrindo o período que vai da Antiguidade Clássica até os dias atuais. Ao examinar a experiência dos homossexuais no contexto das organizações empresariais contemporâneas, esse subsídio histórico serviu para esclarecer que a discriminação sofrida pelos obreiros gays não apenas é resultado da reprodução de preconceitos homofóbicos ainda existentes na sociedade, como também é fomentada pela organização flexível do trabalho que se disseminou desde a década de 1970. Diante dessas constatações, a pesquisa passou a analisar o Estado Democrático de Direito, enquanto paradigma contemporâneo do constitucionalismo assentado pela Constituição Federal de 1988, com enfoque em seus principais elementos: a dignidade da pessoa humana, o pluralismo e os direitos fundamentais. Concluiu-se que o combate à discriminação surge como exigência de concretização desses princípios constitucionais, e que essa necessidade se estende à discriminação por orientação sexual, ainda que este atributo não esteja expressamente elencado pela legislação como critério proibido de diferenciação. A sexualidade de cada indivíduo, afinal, enquanto forma pessoal de realização, integra a sua esfera de autodeterminação protegida pelo Direito. A pesquisa também constatou que o trabalho, enquanto direito fundamental assegurado pela Constituição da República, tem seu sentido axiológico vinculado à realização da dignidade humana. A proteção constitucional é voltada, portanto, para o trabalho que dignifica o homem e não para o trabalho degradante, que instrumentaliza o obreiro ou não Ihe fornece condições para se realizar e participar de forma paritária da vida social. O direito fundamental ao trabalho digno é, assim, incompatível com toda forma de discriminação em matéria de emprego, inclusive a praticada contra homossexuais por conta de sua orientação sexual. A última etapa da pesquisa consistiu na análise da jurisprudência do Tribunal Superior do Trabalho sobre discriminação empregatícia sofrida por trabalhadores gays. Concluiu-se que, em linhas gerais, a Corte Trabalhista tem adotado o discurso constitucional inclusivo, fazendo do Direito do Trabalho um instrumento de proteção à dignidade dos homossexuais diante da discriminação homofóbica.

Palavras-chaves: Discriminação. Orientação sexual. Homossexualidade. Homofobia. Trabalho. Relação de emprego. 


\begin{abstract}
In the light of the fundamental right to decent work, as set by the Constitution of 1988, the aim of this dissertation is to investigate the remedies that Labor Law offers against employment discrimination on the basis of sexual orientation, especially the discrimination faced by gay men. For the most part, the arguments were based on bibliographic research. The study was initiated with a historical contextualization of culturally inherited prejudices against homoeroticism, from the Classic Antiquity to the present day. By examining the experiences of gay men in contemporary organizational context, this historic subside has served to clarify the fact that discrimination faced by these workers is not only a result of the reproduction of still lasting homophobic prejudices, but it is also nurtured by the work organization model which became widespread since the 1970s. Given these findings, the research turned to the analysis of the Democratic Rule of Law State, as the contemporary paradigm of constitutionalism settled by the Federal Constitution of 1988, focusing on its main elements: human dignity, pluralism and fundamental rights. The conclusion was that the elimination of discrimination is a requirement for the realization of these constitutional principles, and that this condition also concerns discrimination based on sexual orientation, even if this attribute is not explicitly listed by the law as a suspect classification. After all, the sexuality of each individual is part of their self-determination sphere protected by the law, as an intimate form of personal fulfillment. The research also found that the axiological meaning of work, as a fundamental right guaranteed by the Constitution, is bound to the realization of human dignity. Therefore, the constitutional protection is aimed to the types of work that dignify man, not to the degrading work, which exploits the worker or denies him the conditions to achieve selfrealization and to participate as an equal in social life. The fundamental right to decent work is thus incompatible with all forms of discrimination in respect of employment, including the discrimination faced by homosexuals because of their sexual orientation. The last phase of the research was the analysis of the precedents set by the Superior Labor Court regarding employment discrimination against gay workers. It was found that, in general, the Court has been adopting an inclusive constitutional discourse, thus making Labor Law an instrument for protecting the dignity of homosexuals in cases of homophobic discrimination.
\end{abstract}

Keywords: Discrimination. Sexual orientation. Homosexuality. Homophobia. Work. Employment relationship. 
1. O AMOR QUE (NÃO) OUSA DIZER SEU NOME: O HOMOEROTISMO NO CURSO DA HISTÓRIA

1.1 Notas introdutórias sobre o(s) preconceito(s) .......................................... 17

1.2 A reinvenção do homoerotismo e das homofobias na história ocidental ............ 22

1.2.1 O homoerotismo na Antiguidade .............................................. 22

1.2.2 A tradição judaico-cristã e o mito da sodomia .................................. 27

1.2.3 A construção moderna da persona homossexual .............................. 35

1.2.4 "We're here, we're queer, get used to it!": os homossexuais saem do armário.

\section{HETEROSSEXISMO E HOMOFOBIAS EM TEMPOS DE TRABALHO}

FLEXÍVEL

2.1 O discurso neoliberal e o modelo toyotista de produção ................................ 54

2.1.1 O trabalho flexível na modernidade líquida .................................. 59

2.1.2 O sofrimento nas organizações maleáveis ...................................... 63

2.2 A homossexualidade na organização contemporânea do trabalho: da marginalização ao reconhecimento

2.2.1 Outsiders nas organizações empresariais: masculinidade,

heterossexismo e trabalho 68

2.2.2 Quando o não dito se converte em atos: a discriminação de homens gays no mundo do trabalho

2.2.3 Homossexualidade e estigma: o trabalhador gay na luta pela autopreservação 85

2.2.4 Homofobia organizacional: a necessidade de desconstrução de um fenômeno assentado em contradições 96

\section{O PRINCÍPIO FUNDAMENTAL DA DIGNIDADE DA PESSOA HUMANA E A} PROIBIÇÃO À DISCRIMINAÇÃO POR ORIENTAÇÃO SEXUAL......................... 107

3.1 Reconhecimento, Direito e Dignidade. 107 
3.2 A dignidade da pessoa humana como matriz principiológica do Estado

Democrático de Direito

3.3 Igualdade e diferença: o enfrentamento à toda forma de discriminação como objetivo do Estado Democrático de Direito

3.4 A orientação sexual como critério de diferenciação proibido pelo ordenamento jurídico brasileiro

\section{O DIREITO FUNDAMENTAL AO TRABALHO DIGNO E A DISCRIMINAÇÃO} POR ORIENTAÇÃO SEXUAL NAS RELAÇÕES DE EMPREGO

4.1 O valor trabalho no Estado Democrático de Direito brasileiro: o direito fundamental ao trabalho digno

4.2 A proibição da discriminação por orientação sexual como exigência do direito fundamental ao trabalho digno

4.3 O papel da Justiça do Trabalho na construção do discurso constitucional trabalhista: o Tribunal Superior do Trabalho e a discriminação empregatícia por orientação sexual

5. CONCLUSÃO

REFERÊNCIAS

APÊNDICE. 


\section{LISTA DE ILUSTRAÇÕES}

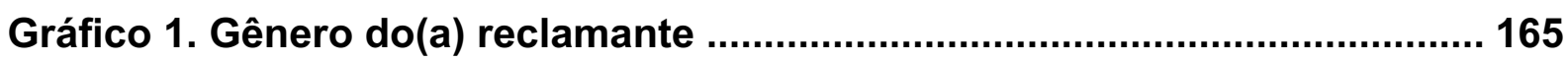

Gráfico 2. Tipos de discriminação alegada ................................................ 167

Gráfico 3. Curva de indenizações por danos morais.................................... 171

Quadro 1. Discriminação por orientação sexual no TST ................................. 190

Quadro 2. Estrutura das relações sociais de reconhecimento ...................... 193 


\section{INTRODUÇÃO}

Não se sabe precisamente quando o desejo sexual entre pessoas do mesmo sexo se manifestou pela primeira vez. Os indícios sobre esse fenômeno são tão antigos quanto os próprios registros da espécie humana ${ }^{1}$. No entanto, o valor que as diferentes culturas nele depositaram e o tratamento que dispensaram às pessoas que vivenciam esse desejo transformaram-se significativamente no curso da história.

Num período de aproximadamente dois milênios, viu-se o homoerotismo ser relativamente incorporado às práticas culturais da Antiguidade Clássica GrecoRomana; tornar-se objeto de censura religiosa da tradição judaico-cristã; converter-se em questão de moralidade e segurança pública, sujeita a severas sanções penais por parte do Estado; convolar-se em patologia, sendo incorporado ao discurso médicocientífico oitocentista; e, a partir do século XX, ser assumido como pauta de uma luta articulada por reconhecimento, voltada à desconstrução das visões negativas socialmente (re)produzidas a seu respeito².

Subjacentes a essas mudanças de postura, estão preconceitos e estereótipos os mais variados em relação ao homoerotismo ${ }^{3}$, que foram sendo estruturados, ao longo do tempo, em padrões de exclusão do diferente e, ainda hoje, se articulam nas complexas e multifacetadas formas discriminatórias pelas quais se expressa a hostilidade contra os homossexuais, no que se convencionou chamar de homofobia ${ }^{4}$.

A própria concepção de homossexual, aliás, como uma identidade social dotada de características e atributos específicos, moldada ao redor das práticas e desejos sexuais de um indivíduo, é uma categoria histórica dos séculos XIX e XX, que servia para reforçar a noção de normalidade sexual, representada pela heterossexualidade ${ }^{5}$.

\footnotetext{
${ }^{1}$ Sobre o assunto, consultar: VECCHIATTI, Paulo Roberto lotti. Manual da homoafetividade: da possibilidade jurídica do casamento civil, da união estável e da adoção por casais homoafetivos. São Paulo: Método, 2012.

${ }^{2}$ Esse percurso é apresentado de forma sintética em: BORRILLO, Daniel. Homofobia: história e crítica de um preconceito. Belo Horizonte: Autêntica Editora, 2010.

${ }^{3}$ YOUNG-BRUEHL, Elisabeth. The anatomy of prejudice. Cambridge: Harvard University Press, 1996, p. 435-436.

${ }^{4}$ BORRILLO, op. cit., p. 13.

${ }^{5}$ Consultar: CECCARELLI, Paulo Roberto. A invenção da homossexualidade. Bagoas: Revista de Estudos Gays, v. 2, p. 71-93, 2008.
} 
Essa concepção negativa da homossexualidade vem, porém, se desarticulando nas últimas décadas do século $X X$ e início do século $X X I$, notadamente com o surgimento e a expansão dos movimentos sociais em defesa dessa parcela da população. Vem se reconstruindo o valor atribuído à identidade homossexual, ao mesmo tempo em que se questionam os parâmetros de normalidade outrora forjados e ainda reproduzidos em relação à sexualidade humana.

A investida na desconstrução de preconceitos homofóbicos tem promovido uma nova transformação na percepção social quanto ao desejo entre pessoas do mesmo sexo.

Com efeito, ganha espaço a compreensão de que a orientação sexual ${ }^{6}$ de um indivíduo não seria, por si só, um critério legítimo para considerá-lo maior ou menor em dignidade. Exatamente por isso, não se prestaria a justificar as práticas discriminatórias a que rotineiramente são submetidos os homossexuais nas diferentes esferas da vida social ${ }^{7}$.

A presente pesquisa debruça-se sobre um dos mais importantes campos em que se desenvolve essa luta por reconhecimento e de enfrentamento às discriminações homofóbicas: o mundo do trabalho.

O trabalho, afinal, como lembra Dejours, tem uma natureza marcadamente ambivalente, pois, ao mesmo tempo em que pode dar ensejo à alienação e à dominação, pode se revelar um instrumento de autorrealização, de inserção social e de afirmação da identidade, desde que se desenvolva sob uma lógica de solidariedade e reconhecimento ${ }^{8}$ - condição essa que, atualmente, enfrenta percalços para se

\footnotetext{
${ }^{6}$ Expressão que aqui se adota em lugar da atualmente criticada opção sexual, que denota algum grau de escolha individual consciente da pessoa quanto ao direcionamento de seu desejo sexual. A esse respeito, consultar: Sobre o assunto, consultar: VECCHIATTI, Paulo Roberto lotti. Manual da homoafetividade: da possibilidade jurídica do casamento civil, da união estável e da adoção por casais homoafetivos. São Paulo: Método, 2012.

${ }^{7}$ RIOS, Roger Raupp; SOUZA, Luiz Gustavo Oliveira de; SPONCHIADO, Tobias. Notícias de Homofobia e Proteção Jurídica Antidiscriminatória. In: DINIZ, Debora; OLIVEIRA, Rosana Medeiros. Notícias de Homofobia no Brasil. Brasília: Letras Livres, 2014. p. 114-126.

${ }^{8}$ Segundo Dejours, "Se as relações sociais de trabalho são principalmente relações de dominação, o trabalho, no entanto, pode permitir uma subversão dessa dominação por intermédio da psicodinâmica do reconhecimento: reconhecimento, pelo outro, da contribuição do sujeito para a administração da defasagem entre a organização prescrita e a organização real do trabalho (...). Esse reconhecimento da contribuição do sujeito à sociedade e à sua evolução por intermédio do trabalho possibilita a reapropriação. Quando a dinâmica do reconhecimento funciona, o sujeito se beneficia de uma retribuição simbólica que pode inscrever-se no âmbito da realização do ego, no campo social". DEJOURS, Cristophe. A banalização da injustiça social. 7. ed. Rio de Janeiro: Editora FGV, 2007, p. 97.
} 
realizar, em face da disseminação do ideal de trabalho flexível e desregulamentado, bem como das pressões pelo individualismo e pela competitividade oriundas dos modelos de produção contemporâneos.

Ocorre que pessoas homossexuais, diante dos preconceitos e da discriminação a que estão expostas na dinâmica das relações de emprego, encontram barreiras adicionais para fazer do trabalho uma experiência positiva, um instrumento de realização pessoal, desenvolvimento da personalidade e edificação identitária.

Cumpre ver, no entanto, que a superação desse conflito entre o eu e o outro no mundo do trabalho, traduzido, no caso, na dualidade heterossexual-homossexual, não depende exclusivamente da renovação dos padrões culturais que orientam a estima socialmente atribuída a certas identidades.

O Direito é também uma dimensão crucial desse processo de reconhecimento, na medida em que, sob a perspectiva do Estado Democrático de Direito, sedimenta a igual dignidade de todo indivíduo como sua matriz axiológica e fornece os instrumentos para que cada pessoa possa, em condições paritárias, desenvolver-se plenamente e participar da vida em comunidade ${ }^{9}$.

Na perspectiva jurídica, portanto, não é o trabalho em si o valor a ser tutelado e promovido, mas sim o trabalho exercido em condições que dignifiquem o ser humano. Daí se falar em um direito fundamental ao trabalho digno ${ }^{10}$, de caráter protetivo e inclusivo.

Tendo em vista essas premissas, esta pesquisa busca investigar as respostas que o Direito do Trabalho brasileiro vem oferecendo ao problema da discriminação por orientação sexual na dinâmica das relações de emprego, tendo por referencial o direito fundamental ao trabalho digno assentado pela Constituição Federal de 1988.

Nesse percurso, tem-se em mira três objetivos: a) compreender as formas como o preconceito e a discriminação homofóbica se manifestam atualmente no mundo do trabalho; b) investigar qual o discurso constitucional condizente com o paradigma do Estado Democrático de Direito, em relação à discriminação empregatícia por orientação sexual, e como esse discurso se traduz, no ordenamento justrabalhista brasileiro pós-1988, em tutela jurídica antidiscriminatória; e c) verificar

\footnotetext{
9 Sobre as dimensões do reconhecimento, consultar: HONNETH, Axel. Luta por reconhecimento: a gramática moral dos conflitos sociais. São Paulo: Ed. 34, 2003.

${ }^{10}$ Sobre o assunto, consultar: DELGADO, Gabriela Neves. Direito fundamental ao trabalho digno. 2. ed. São Paulo: LTr, 2015.
} 
em que medida esse discurso vem encontrando respaldo na atuação do Tribunal Superior do Trabalho, desde a reforma do Poder Judiciário e, em especial, da Justiça do Trabalho, promovida pela Emenda Constitucional 45/2004 ${ }^{11}$.

A realização dos objetivos a que se propõe esta pesquisa, de caráter eminentemente dedutivo, fez-se pela conjugação da pesquisa bibliográfica multidisciplinar $^{12}$ com a pesquisa e análise de jurisprudência do Tribunal Superior do Trabalho. Alguns recortes temáticos se fizeram necessários, no entanto, para definir com maior precisão o objeto de pesquisa.

Não se desconhece, por exemplo, a contribuição que uma abordagem efetivamente interseccional das relações sociais ${ }^{13}$ proporcionaria à discussão, permitindo uma aproximação ao tema mais ampla, por considerar a influência de elementos como raça e classe na construção da discriminação homofóbica. Todavia, sem ignorar a complexidade das relações sociais, o enfoque da pesquisa, por questões didáticas e limitações inerentes à dissertação, se ateve primordialmente às categorias sexo, gênero e orientação sexual.

Na mesma linha, muito embora a discriminação por orientação sexual seja um problema enfrentado por homossexuais de todos os gêneros, a pesquisa, sobretudo

11 Consultar: DELGADO, Maurício Godinho; DELGADO, Gabriela Neves. Tratado jurisprudencial de direito constitucional do trabalho. São Paulo: Editora Revista dos Tribunais, 2013.

${ }^{12}$ Entre os campos do conhecimento que embasam a pesquisa, merecem destaque o Direito Constitucional, o Direito do Trabalho, a História, a Sociologia do Trabalho, a Psicologia e a Psicodinâmica do Trabalho.

${ }^{13}$ De acordo com Bilge, a interseccionalidade "refere-se a uma teoria transdisciplinar voltada a compreender a complexidade das identidades e das desigualdades sociais através de uma abordagem integrada. Ele refuta a separação e a hierarquização dos principais eixos de diferenciação social que são as categorias de sexo/gênero, classe, raça, etnia, idade, deficiência e orientação sexual. A abordagem interseccional vai além de um simples reconhecimento da multiplicidade de sistemas de opressão que operam a partir dessas categorias e postula sua interação na produção e reprodução das desigualdades sociais" (BILGE, S. Théorisations féministes de l'intersectionnalité. Diogène, n. 225, p. 70-88, 18 jan. 2010 , p. 70, tradução livre, no original: “(...) une théorie transdisciplinaire visant à appréhender la complexité des identités et des inégalités sociales par une approche intégrée. Elle réfute le cloisonnement et la hiérarchisation des grands axes de la différenciation sociale que sont les catégories de sexe/genre, classe, race, ethnicité, âge, handicap et orientation sexuelle. L'approche intersectionnelle va audelà d'une simple reconnaissance de la multiplicité des systèmes d'oppression opérant à partir de ces catégories et postule leur interaction dans la production et la reproduction des inégalités sociales"). Sobre o assunto, consultar também: HIRATA, Helena. Gênero, classe e raça Interseccionalidade e consubstancialidade das relações sociais. Tempo social, v. 26, n. 1, p. 61-73, 2014; e KERGOAT, Danièle. Dinâmica e consubstancialidade das relações sociais. Novos Estudos-CEBRAP, n. 86, p. 93-103, 2010. 
ao enveredar por abordagens históricas e sociológicas, deparou-se com a necessidade de restringir a análise à experiência de homens gays nas relações de emprego. Esse recorte, em específico, derivou da conclusão de que os preconceitos e a discriminação por orientação sexual de que são vítimas homens e mulheres, embora em muito assemelhados e inter-relacionados, apresentam especificidades quanto às origens, motivações e configurações ${ }^{14}$, de modo que, tentar abarcá-los, nos limites desta pesquisa, conduziria a uma simplificação empobrecedora de seu objeto.

Nesse percurso, o Capítulo 1 é dedicado à construção de um breve escorço histórico dos preconceitos homofóbicos, que serve, nos capítulos subsequentes, para lançar luzes sobre as motivações e as formas pelas quais se manifesta a discriminação empregatícia contra homossexuais. Com esse intento, são apresentadas as transformações da compreensão social quanto ao homoerotismo ocorridas desde a Antiguidade Clássica até os dias atuais.

O Capítulo 2 investiga a inter-relação existente entre os preconceitos de matiz homofóbico e o modelos contemporâneos de produção e de gestão do trabalho. Busca-se demonstrar, num contexto organizacional de trabalho flexível, mercantilização das relações empregatícias, instrumentalização do trabalhador, alta competitividade e banalização de injustiças sociais, em que medida esses modelos oferecem estímulos, mesmo que veladamente, à disseminação de práticas discriminatórias de natureza homofóbica.

Nessa linha, são estudadas, ainda, as estratégias de sobrevivência no emprego adotadas por trabalhadores homossexuais, diante da experiência concreta ou da expectativa de discriminação por orientação sexual. Por derradeiro, o capítulo também tem a pretensão de expor as contradições subjacentes à existência de uma homofobia organizacional.

O Capítulo 3 explora as bases sobre as quais se assenta o paradigma do Estado Democrático de Direito, notadamente o pluralismo, o respeito e a promoção da dignidade da pessoa humana, bem como a garantia dos direitos fundamentais. A partir dessas premissas, examina-se o tratamento conferido pelo ordenamento jurídico brasileiro ao tema da discriminação, sob a égide da Constituição de 1988, especialmente em relação à homossexualidade.

14 Sobre o tema, consultar: IRIGARAY, Hélio Arthur Reis; FREITAS, Maria Ester de. Sexualidade e organizações: estudo sobre lésbicas no ambiente de trabalho. Organ. Soc., Salvador, v. 18, n. 59, p. 625-641, dez. 2011. 
O Capítulo 4, por fim, dando seguimento à construção de um discurso constitucional coerente com a matriz axiológica da Constituição Federal de 1988, explora o conteúdo do direito fundamental ao trabalho digno e da tutela antidiscriminatória justrabalhista, com vistas a identificar as normas passíveis de aplicação em casos de discriminação empregatícia por orientação sexual.

Em um segundo momento, o capítulo traz, ainda, o resultado da pesquisa de jurisprudência no Tribunal Superior do Trabalho. Nesse rumo, aponta as principais características dos casos sobre discriminação homofóbica que chegam ao conhecimento da Corte Trabalhista e demonstra em que medida a argumentação jurídica dos acórdãos reflete o discurso constitucional delineado nos Capítulos 3 e 4 .

O conjunto da pesquisa buscou, portanto, traçar reflexões quanto ao potencial do Direito do Trabalho brasileiro para servir de instrumento eficiente na proteção e afirmação da dignidade dos trabalhadores homossexuais diante da discriminação empregatícia por orientação sexual. 


\title{
1. O AMOR QUE (NÃO) OUSA DIZER SEU NOME: O HOMOEROTISMO NO CURSO DA HISTÓRIA
}

\author{
From all I did and all I said \\ let no one try to find out who I was. \\ An obstacle was there that changed the pattern \\ of my actions and the manner of my life. \\ An obstacle was often there \\ to stop me when l'd begin to speak. \\ From my most unnoticed actions, \\ my most veiled writing - \\ from these alone will I be understood. \\ But maybe it isn't worth so much concern, \\ so much effort to discover who I really am. \\ Later, in a more perfect society, \\ someone else made just like me \\ is certain to appear and act freely. \\ Constantine Cavafy ${ }^{15}$
}

\subsection{Notas introdutórias sobre o(s) preconceito(s)}

A palavra preconceito denota "ideia, opinião ou sentimento desfavorável formado a priori, sem maior conhecimento, ponderação ou razão"16. Em inglês, prejudice, que remonta ao latino praejudicium, também designa um juízo concebido previamente e desprovido de um exame crítico apurado a respeito de seu objeto.

Sem se distanciar da própria etimologia do termo, a grande maioria dos estudos sobre o preconceito parte da premissa de que se tem em vista um fenômeno uno, que pode se manifestar sob diferentes formas ${ }^{17}$. Em geral, o preconceito é definido como uma atitude negativa dirigida a um grupo social definido e a qualquer pessoa que se acredite pertença a esse grupo. Compõe-se por ideias rígidas, geralmente traduzidas por meio de adjetivos convencionados (com frequência, na forma de estereótipos), que se mostram impermeáveis a experiências concretas que poderiam contrariá-las ${ }^{18}$.

${ }^{15}$ CAVAFY, C. P. Collected Poems. Tradução por Edmund Keeley and Philip Sherrard. Princeton University Press, 1992.

${ }^{16}$ HOUAISS, Antônio. Grande Dicionário Houaiss da Língua Portuguesa. Disponível em: <http://houaiss.uol.com.br/>. Acesso em: 30 de novembro de 2015.

17 Cf. COLLINS, Barry E. Social Psychology: Social Influence, Attitude Change, Small Groups, and Prejudice, Reading, Mass.: Addison-Wesley, 1970; ADORNO, Theodor W., et al. The authoritarian personality. New York: Harper, 1950.

${ }^{18}$ YOUNG-BRUEHL, Elisabeth. The anatomy of prejudice. Cambridge: Harvard University Press, 1996, p. 43-44. 
Seguindo nessa linha, Rios consigna que:

Preconceito é o termo utilizado, de modo geral, para indicar a existência de percepções negativas por parte de indivíduos e grupos, onde estes expressam, de diferentes maneiras e intensidades, juízos desfavoráveis em face de outros indivíduos e grupos, dado o pertencimento ou a identificação destes a uma categoria tida como inferior $^{19}$.

Segundo Rios, quando há materialização, "no plano concreto das relações sociais, de atitudes arbitrárias, comissivas ou omissivas, relacionadas ao preconceito, que produzem violação de direitos dos indivíduos e dos grupos", tem-se a discriminação ${ }^{20}$.

A despeito da evidente utilidade das correntes teóricas tradicionais para a compreensão do preconceito, entende-se que abordar o termo no singular para daí explorar seus diferentes alvos pode limitar sobremaneira o exame do pesquisador, ao simplificar fenômenos complexos, por vezes permeados de especificidades, e que, talvez, não possam ser adequadamente reunidos sob um denominador comum.

A partir da revisitação de mais de cinquenta anos de pesquisas das Ciências Sociais em torno dessa temática e da elaboração de uma tipologia própria, YoungBruehl cinde a noção de preconceito como unidade, traçando distinções fundamentais entre o que denomina etnocentrismos e as chamadas ideologias do desejo, ou orexismos $^{21}$.

O preconceito etnocêntrico, segundo Young-Bruehl, consiste em situar o próprio grupo ou etnia como centro da existência e do pensamento, dispensando juízos negativos a um, alguns ou todos os grupos a ele externos. Cuida-se de uma forma de preconceito voltada à preservação grupal daqueles que o manifestam, tendo por referência uma identidade já existente no mundo, com uma história própria, e se articulando em torno de um complexo centrípeto de valores e comportamentos, a fim de promover o valor dessa identidade em comparação com outras identidades ${ }^{22}$.

\footnotetext{
${ }^{19}$ RIOS, Roger Raupp. O conceito de homofobia na perspectiva dos direitos humanos e no contexto dos estudos sobre preconceito e discriminação. In: POCAHY, Fernando. Rompendo - silêncio: homofobia e heterossexismo na sociedade contemporânea. Porto Alegre: Nuances, 2007, p. 28.

${ }^{20}$ Ibid., p. 28.

${ }^{21}$ No original, orecticism, do grego orektikos - desejosos ou pertencente aos desejos (YOUNG-BRUEHL, Elisabeth. The anatomy of prejudice. Cambridge: Harvard University Press, 1996, p. 185).

22 Ibid., p. 184-193.
} 
Os orexismos, por sua vez, são visões de mundo moldadas pelo desejo, que produz ou se articula em ideologias. São mecanismos de defesa, que, mediante a construção de bodes expiatórios, projetam em outras pessoas e grupos os desejos proibidos ou reprimidos do orexista. Preconceituosos desse tipo fantasiam o pertencimento a um grupo superior imaginário, que supostamente existiu desde sempre ou desde um passado imemorial. Seu enfoque é, portanto, centrífugo e supremacista, acentuando diferenças e ensejando a exclusão dos que supostamente o ameaçam - indivíduos considerados membros de um grupo também imaginário no qual se projeta a aversão orexista. Se o etnocentrismo se pauta em comparações (cultos v. bárbaros) e comporta gradações, sendo mais flexível; as diferenças demarcadas pelo orexismo, todavia, são dualistas e inconciliáveis (humanos v. não humanos, por exemplo). Ademais, não raro, os orexistas inscrevem essas diferenças intransponíveis na própria legislação, a fim de reforçá-las ${ }^{23}$.

Para Young-Bruehl, preconceitos como o sexismo, o racismo, o antissemitismo e a homofobia, em suas versões modernas, se articulam, quase sempre, na forma de ideologias do desejo. Além de se entrecruzarem, com diferentes motivações, finalidades e consequências, esses preconceitos, sob uma perspectiva que remonta à psicanálise, podem assumir formas obsessivas, histéricas ou narcísicas $^{24}$.

Os preconceituosos obsessivos formam uma imagem de suas vítimas como inimigos onipresentes, dados a conspirações; seres perversos, infecciosos e que, em último grau, precisam ser eliminados. São típicos de pessoas tendentes a ideias fixas e comportamentos rituais, por meio dos quais extravasam seu sadismo, sem estabelecer conexões sentimentais com os alvos de suas ações ${ }^{25}$. A cristalização desse tipo de preconceito em certos grupamentos, com picos de elevada intensidade, tende a encontrar condições propícias nos períodos de depressão e desilusão como se deu com o antissemitismo, por ocasião da Segunda Guerra Mundial. Esse, aliás, costuma ser o modus operandi da promoção oficial de preconceitos em Estados autoritários ou tirânicos ${ }^{26}$.

\footnotetext{
${ }^{23}$ YOUNG-BRUEHL, Elisabeth. The anatomy of prejudice. Cambridge: Harvard University Press, 1996, p. 184-193.

${ }^{24}$ Ibid., p. 185.

${ }^{25}$ Ibid., p. 34.

${ }^{26}$ Ibid., p. 355.
} 
Os preconceitos histéricos, por outro lado, são aqueles por meio dos quais o agente inconscientemente aponta, em determinado grupo considerado inferior, práticas e desejos agressivos e/ou sexuais que ele reprime em si mesmo. A hipocrisia é um traço característico de seus expoentes, bem como a pretensão de marginalização das vítimas - que, para o histérico, deveriam reconhecer o seu devido lugar (físico e simbólico) subalterno e com ele se conformar. A eliminação do objeto do desprezo não é o fim efetivamente visado, mas a possibilidade de afirmação da hierarquia entre os grupos, de uma marginalização contínua ${ }^{27}$.

O tipo narcisista, finalmente, tem dificuldades para processar a ideia de que existam diferenças e se manifesta, em alguma medida, nos dois tipos anteriores. Do ponto de vista da psicanálise, toda pessoa, no começo de sua vida, experimenta uma condição de narcisismo primário, caracterizada pela autossuficiência provida pela indiferenciação para com o corpo materno, no atendimento de suas necessidades. Essa condição eventualmente se rompe, exigindo do indivíduo a construção da capacidade de considerar os outros como seres separados, diferentes, com necessidades próprias. O desenvolvimento do indivíduo, a partir dessa experiência, pode levar à formação da personalidade narcisista, fortemente centrada no eu, na autopreservação, e com dificuldades ou medo de lidar com a diferença. Os preconceitos narcisistas são, portanto, erguidos em torno da diferença e usam seus alvos na manutenção da autoestima e do sentimento de superioridade do indivíduo. No caso dos homens, ele se processa notadamente em torno da diferença sexual, experimentada pela primeira vez quando do rompimento com a simbiose materna. $A$ ausência física (feminino) ou simbólica do falo (afeminado), nesse rumo, passa a representar a frustração, a incompletude, o negativo. Daí a tendência do narcisista a se agrupar com aqueles que lhe são semelhantes, em busca do sentimento de fusão, reagindo com veemência e agressividade a tudo que incorpore ou simbolize o diferente. Na forma grupal, cuida-se de um preconceito de negação: "não há outros, apenas o nós"28.

Ao aprofundar a tipologia, Young-Bruehl destaca que, entre os preconceitos mais disseminados, a homofobia demonstra historicamente uma especial aptidão para

\footnotetext{
${ }^{27}$ YOUNG-BRUEHL, Elisabeth. The anatomy of prejudice. Cambridge: Harvard University Press, 1996, p. 34.

${ }^{28}$ Ibid., p. 230-238.
} 
se manifestar em todos os tipos anteriormente descritos ${ }^{29}$. De fato, tendo em vista o espectro amplo de transformações sociopolíticas ao longo de mais de um milênio, o resgate da história ocidental evidencia uma larga pluralidade de formas pelas quais se estruturaram dinamicamente tanto o homoerotismo quanto o preconceito contra ele direcionado.

A despeito dessa variabilidade de motivações, modos de expressão e objetivos, a homofobia, enquanto conceito recentemente forjado, é também geralmente invocada no singular. Essa condensação de manifestações complexas em uma imaginária unidade decorre, em parte, da proeminência histórica de algumas expressões do preconceito homofóbico, notadamente daquele direcionado à imagem do homem afeminado.

Mas, como será adiante explorado, a partir do momento em que se compreende, a um, que a própria homossexualidade é um conceito socialmente forjado, uma construção com contornos e simbologia característicos do cenário recente em que fora cunhado; e, a dois, que o homoerotismo compõe-se, na verdade, de uma multiplicidade de expressões possíveis da sexualidade humana ${ }^{30}$; também assim devem ser vislumbrados os preconceitos que os têm em mira.

No decurso do tempo, produziram-se e se reproduziram diferentes homofobias, por vezes articuladas concomitantemente. Com características as mais variadas, o homoerotismo já ensejou reações de intensidades díspares, sendo os homossexuais ora compreendidos como seres moralmente degenerados e inferiores, ora como pecadores, ora como ameaças à estabilidade social e aos costumes, ora como doentes mentais - por vezes, um misto dessas abordagens. De outro lado, o emprego do plural para fazer referência à homofobia implica reconhecer que o preconceito antilésbico é fundamentalmente distinto do de matiz antigay, estando umbilicalmente relacionado às questões de gênero que moldaram e moldam a existência da mulher em sociedade ${ }^{31}$, como a invisibilidade feminina histórica e, principalmente, a anulação da sexualidade da mulher ${ }^{32}$.

\footnotetext{
${ }^{29}$ YOUNG-BRUEHL, Elisabeth. The anatomy of prejudice. Cambridge: Harvard University Press, 1996, p. 36.

${ }^{30}$ CECCARELLI, Paulo Roberto; FRANCO, Samuel. Homossexualidade: verdades e mitos. Bagoas: Revista de Estudos Gays, v. 5, p. 119-129, 2010, p.121.

${ }^{31}$ YOUNG-BRUEHL, op. cit., p. 537-538.

${ }^{32}$ Recomenda-se a leitura da obra de Borges, no tocante à discriminação de gênero contra mulheres no contexto das organizações empresariais: BORGES, Lara Parreira de Faria.
} 
Nesse percurso histórico, como se há de ver, as homofobias apresentaram, pelo menos, três picos em intensidade, em diferentes contextos e dando ensejo a diferentes preconceitos: o primeiro, quando da derrocada da era greco-romana, por volta do ano 300 DC; o segundo, ao fim de seis séculos de relativa tolerância cristã às práticas homoeróticas, em 1300; e o terceiro, com o encerramento, ao fim do século XIX, da era inaugurada pela Revolução Francesa em 1789 - diferentes contextos, dando ensejo a diferentes preconceitos ${ }^{33}$.

\subsection{A reinvenção do homoerotismo e das homofobias na história ocidental}

Os indícios de práticas homoeróticas são tão antigos quanto os próprios registros da existência humana, sendo observados na quase totalidade dos grupos sociais de que se tem notícia ${ }^{34}$. Reconstituir essa história, em detalhes, portanto, seria uma tarefa hercúlea, que se afastaria demasiadamente do escopo desta pesquisa.

A despeito da longa história do homoerotismo, desde tempos imemoriais, o tratamento e as explicações a ele dispensados socialmente jamais foram uniformes. Nesse sentido, elucidar, mesmo que superficialmente, a trajetória histórica do desejo entre pessoas do mesmo sexo, contextualizando as mudanças operadas na compreensão social desse tipo de manifestação sexual, permite esclarecer, noutra mão, a origem imbricada das hostilidades que, justapostas, ainda hoje a têm em mira.

\subsubsection{O homoerotismo na Antiguidade}

Se um breve escorço histórico da temática homossexual é indispensável para lançar luz sobre a atualidade de múltiplas formas de aversão enfrentadas por pessoas homossexuais, mormente no mundo do trabalho, parece adequado um recorte que tome, como ponto de partida, a Antiguidade greco-romana, por sua decisiva influência na formação da tradição ocidental — inclusive, jurídica.

A fim de se evitar o anacronismo, entretanto, é preciso cautela na aplicação irrefletida de algumas categorias hodiernas a contextos pretéritos que não dispunham de equivalentes semânticos. É a razão pela qual, ao se falar em uma história da

Espiando por trás da persiana: um olhar sobre a discriminação traduzida em assédio moral contra a mulher. São Paulo: LTr, 2015.

${ }^{33}$ YOUNG-BRUEHL, Elisabeth. The anatomy of prejudice. Cambridge: Harvard University Press, 1996, p. 435-436.

${ }^{34}$ LIMA, Suzana Borges Viegas de. O estatuto jurídico das relações homoafetivas. Brasília: Gazeta Jurídica, 2015, p. 9. 
homossexualidade e da homofobia (conceitos que, como se verá, são ainda relativamente recentes), está-se a adotar uma acepção lata de ambos os termos, que remete à compreensão e ao tratamento dispensados, em diferentes épocas, no Ocidente, ao desejo e às práticas sexuais entre pessoas do mesmo sexo. Nesse sentido, eventual menção à homossexualidade ou à homofobia em relação a momentos históricos anteriores à construção moderna do personagem homossexual, como alude Foucault ${ }^{35}$, deve ser compreendida como desvinculada de questões de viés identitário, hoje indissociáveis da concepção de orientação sexual.

Feita a ressalva, destaca-se, no imaginário popular, a ideia de que, no período greco-romano, a homossexualidade, de uma forma generalizada, era não apenas tolerada, mas celebrada e associada a importantes valores morais e filosóficos. $\mathrm{O}$ estudo dessas civilizações, todavia, sugere um quadro bem mais complexo que a imagem sedimentada pelo senso comum: embora práticas homoeróticas, de fato, integrassem essas culturas, suas expressões socialmente aceitas enquadravam-se em determinados padrões convencionados ${ }^{36}$.

Na Grécia Antiga, o homoerotismo era elemento, principalmente, da chamada paiderastia (combinação de pais - garoto - e eran - amar), um tipo de relação tradicional para muitos povos da Antiguidade, firmada entre um homem adulto e um jovem púbere ${ }^{37}$. Esse vínculo era composto por um mestre (erastes) e um pupilo (eromenos), com o intuito de transmissão de conhecimentos sobre a vida, a cidadania, a guerra e o amor, havendo, também, expectativas de prática sexual entre as partes. Instituição social sedimentada por séculos de tradição, era vista como obrigação de todo cidadão, antes do casamento. Conquanto poucos registros sobrevivam à atualidade, relacionamentos homossexuais entre adultos (homens e mulheres) também foram documentadas no período, embora aparentemente não gozassem de grande aprovação social ${ }^{38}$.

A obra "O Banquete", de Platão, diálogo redigido em torno do ano 385 a.C., aborda as relações então vigentes de paiderastia. A narrativa apresenta uma festa na residência do poeta ateniense Agaton, em que conversam sobre o amor (eros) o

\footnotetext{
${ }^{35}$ FOUCAULT, Michel. História da sexualidade I: a vontade de saber. Rio de Janeiro: Edições Graal, 1988, p. 43-44.

${ }^{36}$ FONE, Byrne. Homophobia: a history. Nova York: Picador, 2000, p. 17.

${ }^{37}$ Não se pode confundir o vínculo da paiderastia com a pedofilia, conduta também repudiada na sociedade grega da Antiguidade.

${ }^{38}$ FONE, op. cit., p. 17-25.
} 
escritor Fedro; Pausânias, o amante de Agaton; o dramaturgo Aristófanes; o médico Erixímaco; o político Alcibíades e o filósofo Sócrates ${ }^{39}$.

Pausânias, ao se manifestar, opina que o vínculo entre o mestre e o jovem aprendiz seria a forma mais elevada e verdadeira de amor, porquanto as demais relações, a exemplo da existente entre um homem e uma mulher ou entre homens adultos, não seriam aptas a gerar a troca de conhecimentos que tanto enobrece o primeiro tipo. Já Aristófanes, em sua fala, invoca a mitologia ao afirmar que, na origem, seriam três os gêneros da humanidade, macho, fêmea e andrógino ${ }^{40}$; os deuses, contudo, sentindo-se ameaçados por esses seres magníficos que haviam criado, decidiram separá-los em duas metades, enfraquecendo-os e eliminando o risco de que se voltassem contra seus criadores. Desde então, os humanos vivem uma busca por integridade, que se traduz no que chamamos amor:

Portanto, cada um de nós não passa de uma metade que combina de um ser humano inteiro, uma vez que todos exibem, como o peixe chato, os vestígios de ter sido cortado em dois; e cada um se mantém à procurar da metade que combina. Todos os homens que são seções daquele tipo composto que no início foi chamado de andrógino são aficionados de mulheres (...). Todas as mulheres que constituem seções de mulheres não experimentam atração por homens; são, pelo contrário, atraídas por mulheres, as lésbicas provindo desta classe. Homens que constituem seções de homens voltam-se para homens (...). Ora, quando um deles, que seja amante de rapazes, que seja um amante de qualquer outra ordem, acontece de encontrar sua própria metade, os dois parceiros são maravilhosamente tocados pela amizade, a intimidade e o amor sexual, sendo dificilmente convencidos a se separarem, mesmo que seja por um momento ${ }^{41}$.

A homossexualidade, no entanto, atendia a outros papéis sociais, na civilização grega, para além da troca intelectual pertinente à pederastia. Sua aplicação no militarismo ${ }^{42}$ é um exemplo. Fortunato Pastore menciona, nesse específico, o

${ }^{39}$ PLATÃO. O banquete. Tradução, apresentação e notas Edson Bini. São Paulo: EDIPRO, 2012.

40 "Em primeiro lugar, havia três tipos de seres humanos e não apenas os dois, macho e fêmea, que existem na atualidade; havia também um terceiro tipo, que possuía em si porções iguais dos outros dois - tipo do qual sobrevive o nome, embora ele próprio haja desaparecido. De fato, o andrógino então constituía uma unidade tanto na forma quanto no nome, um composto de ambos os sexos, o qual compartilhava igualmente do masculino e do feminino (...)" (Ibid., p. 49-50).

${ }^{41}$ Ibid., p. 54-55.

42 Lima chama atenção, nesse ponto, ao contraste existente entre a aplicação grega das relações homoafetivas em prol da vitória na guerra e a posição discriminatória ainda vigente em muitos Estados contemporâneos, refratária à presença de homossexuais nas forças armadas. É emblemática, nesse específico, a recentemente superada política norteamericana do "Don't ask, don't tell", que postulava a tolerância à presença de homossexuais na carreira militar, conquanto que sua condição permanecesse oculta (LIMA, Suzana Borges 
Batalhão Sagrado de Tebas, unidade de elite inovadora, criada pelo Comandante Górgidas, em 378 a.C., e constituída por cento e cinquenta casais de amantes do sexo masculino:

O Batalhão Sagrado era muito temido pela sua bravura e enorme coragem. Eram guerreiros ferozes que se mantinham unidos por laços amorosos. Os hoplitas do Bando Sagrado juravam que nunca dariam vantagem ao inimigo e nunca iriam fugir de um combate. Lutavam em fileiras cerradas e eram bastante disciplinados. As questões da homossexualidade e do treinamento físico e militar eram fundamentais no contexto das sociedades erigidas sob a lógica das póleis ${ }^{43}$.

Apesar de culturalmente aceitas, as práticas sexuais entre homens, a depender da observância de alguns limites, poderiam repercutir negativamente no status do cidadão. Isso porque a identidade masculina ${ }^{44}$ grega era fortemente vinculada à imagem de dominância e ao comprometimento com os deveres da vida cívica, da atividade política, do casamento e da guerra - incompatível, portanto, com qualquer associação ao universo das mulheres, considerado inferior e complacente. Nesse sentido, muito embora fosse, em tese, indiferente o sexo biológico do parceiro com o qual o homem adulto se relacionasse, era crucial, em termos de aceitação social, o papel assumido nessas interações, se dominante (e, portanto, masculino) ou submisso (passivo e, por associação, feminino). Por essa razão, nas relações de pederastia abrigadas pela cultura grega, o cidadão adulto deveria necessariamente assumir a dominância, cabendo ao jovem aprendiz desempenhar o papel submisso ${ }^{45}$.

Em suma, observadas as convenções sociais, o comportamento homossexual masculino ${ }^{46}$, no período grego, não era visto como reprovável; como tampouco o eram outras práticas sexuais sem finalidade reprodutiva ${ }^{47}$. A rejeição era para com àqueles

Viegas de. 0 estatuto jurídico das relações homoafetivas. Brasília: Gazeta Jurídica, 2015, p. 14).

${ }^{43}$ PASTORE, Fortunato. O Batalhão Sagrado de Tebas: militarismo e homoafetividade na Grécia Antiga. Revista Trilhas da História. Três Lagoas, v. 1, n. 1., jun./nov. 2011, p. 40-41. ${ }_{44}$ Entenda-se, aqui, aquele conjunto de atributos culturalmente definidos como representativos da noção de masculino.

${ }^{45}$ FONE, Byrne. Homophobia: a history. Nova York: Picador, 2000, p. 25-27

${ }^{46}$ Muito embora sobrevivam à atualidade vestígios consistentes das práticas homoeróticas masculinas, têm-se poucas referências à homossexualidade feminina na Grécia Antiga. A par da menção a essa possibilidade na narrativa mitológica de Aristófanes, n'O Banquete de Platão, talvez os relatos mais notórios sejam aqueles relacionados à poetisa Safo, natural da ilha de Lesbos.

47 A maior liberdade em matéria do exercício da sexualidade (que, no posterior período judaico-cristão, viria a se tornar questão de suma importância para a moral religiosa) é facilmente perceptível na própria mitologia grega, permeada de narrativas sexuais entre deuses ou deuses e mortais, de iguais ou diferentes sexos. 
que transgredissem as barreiras dos costumes, como os homens dedicados, com exclusividade, à passividade sexual em relações homoeróticas, ou que demonstrassem hábitos e trejeitos convencionalmente tidos por femininos. O estigma social, pois, descansava sobre a dualidade dominância-submissão e, em último grau, à efeminação do homem ${ }^{48}$.

Tal qual a Antiguidade grega, também na República e em boa parte do Império Romano, o homoerotismo era praticado e gozava de certa receptividade, observados com maior rigor os limites dos papéis masculino e feminino, organizados de acordo com uma ordem social de caráter marcadamente andro e falocêntrico ${ }^{49}$.

Algumas diferenças entre as duas civilizações, todavia, sobressaíam, a começar pelo fato de que a relação sexual entre homens adultos e jovens nascidos livres, ao contrário da cultura grega, não era, a princípio, encorajada na Roma antiga. Já o sexo entre senhores e seus escravos (concubinus) era comum e disseminado. As barreiras ao relacionamento com jovens livres foram, no entanto, abrandadas, a partir da conquista da Grécia por Roma e do consequente processo de aculturação ${ }^{50}$.

De outra parte, a prostituição masculina era atividade lícita e, durante o reinado do Imperador Augusto (27 AC a $14 \mathrm{DC}$ ), sujeitava-se, inclusive, à tributação. Há, ainda, indícios de que algumas relações entre homens lograram obter reconhecimento formal, semelhante ao conferido ao casamento entre homem e mulher. De acordo com relatos de Cícero, Marcial e Juvenal a esse respeito, ao menos dois imperadores romanos, Nero e Heliogábalo, teriam se casado com parceiros do mesmo sexo ${ }^{51}$.

A integração pacífica do homoerotismo à cultura dos povos da Antiguidade tornou-se, porém, objeto de maiores contestações, poucos séculos antes do início da era cristã, principalmente devido à expansão da influência alcançada por alguns segmentos religiosos. Com o entrelaçar do pensamento religioso às estruturas de poder, a aceitação do relacionamento entre pessoas do mesmo sexo passa a ser posta em questão ${ }^{52}$.

\footnotetext{
${ }^{48}$ FONE, Byrne. Homophobia: a history. Nova York: Picador, 2000, p. 29.

${ }^{49}$ VECCHIATTI, Paulo Roberto lotti. Manual da homoafetividade: da possibilidade jurídica do casamento civil, da união estável e da adoção por casais homoafetivos. São Paulo: Método, 2012, p. 7.

${ }^{50}$ Ibid., p. 7.

${ }^{51}$ FONE, op. cit., p. 44-48

${ }^{52}$ lbid., p. 60-62.
} 


\subsubsection{A tradição judaico-cristã e o mito da sodomia}

Mudanças em torno da percepção social começam a despontar por volta do ano $100 \mathrm{AC}$, com o surgimento de discursos que consideravam as relações sexuais entre homens antinaturais e prejudiciais à estabilidade social. Num primeiro momento, o ascetismo que os caracterizava derivou do encontro da postura antissexual do neoplatonismo com a tradição e os costumes hebraicos. Posteriormente, vieram a embasar o nascente cristianismo, igualmente empenhado em sua rejeição ao culto às divindades antigas e às tradições a elas associadas ${ }^{53}$.

A repulsa judaica ao homoerotismo remonta às prescrições de Levítico e a outras passagens das escrituras sagradas, num movimento de matiz etnocêntrico do povo hebreu. Buscava-se assegurar, à época, a expansão do grupo com o resguardo de sua identidade e da pureza de sua linhagem, mediante o estabelecimento de normas de conduta sexual que garantissem a ancestralidade, diferenciando-os, por exemplo, dos canaanitas ${ }^{54}$. Sua afirmação como grupo dava-se pela rejeição aos costumes de outros povos que lhe eram contemporâneos. O modelo de pederastia institucionalizada e outras atividades sexuais sem finalidade reprodutiva ou externas ao laço do matrimônio (em especial, o homoerotismo), não se enquadravam na cultura judaica e eram, por conseguinte, condenadas ${ }^{55}$.

Durante a Era Cristã, se disseminou essa compreensão da sexualidade que contrapõe a carne ao espírito, censurando os prazeres terrenos do sexo em prol da atividade sexual exclusivamente reprodutiva e interna ao casamento. Em que pese não se tenha registro de opiniões expressas de Cristo sobre a homossexualidade, a reprovação do cristianismo ao homoerotismo se ancora, primordialmente, em um número seleto de passagens do Antigo e do Novo Testamentos, com especial ênfase na história de Sodoma e Gomorra - excertos a que autoridades religiosas ainda recorrem com frequência para embasar suas manifestações contrárias à homossexualidade ${ }^{56}$.

\footnotetext{
${ }^{53}$ FONE, Byrne. Homophobia: a history. Nova York: Picador, 2000, p. 62.

${ }^{54}$ YOUNG-BRUEHL, Elisabeth. The anatomy of prejudice. Cambridge: Harvard University Press, 1996, p. 437.

${ }^{55}$ VECCHIATTI, Paulo Roberto lotti. Manual da homoafetividade: da possibilidade jurídica do casamento civil, da união estável e da adoção por casais homoafetivos. São Paulo: Método, 2012, p. 20.

${ }^{56}$ FONE, op. cit., p. 70-75.
} 
De acordo com a narrativa bíblica, dois anjos enviados por Deus à cidade de Sodoma são recebidos e abrigados por Ló, em sua residência. Eis que, quando iam se pôr a dormir, os homens da cidade batem à sua porta, exigindo lhes fossem apresentados os hóspedes de Ló. Temendo por aqueles que abrigara, ele tenta dissuadir os cidadãos de lhes causar qualquer mal e, assim, oferece suas filhas para que delas fizessem o que desejassem. Com o avanço, porém, dos sodomitas, os anjos ferem-nos com cegueira e determinam a Ló e a sua família que se retirem da cidade, sem olhar para trás, pois, diante dos graves pecados cometidos pelos cidadãos de Sodoma e Gomorra, Deus destruiria ambas as cidades - e assim o fez, reduzindoas a pó, com as chamas que sobre elas lançou ${ }^{57}$.

Ao longo de dois milênios, formou-se praticamente um consenso de que a perversidade dos sodomitas que teria dado causa à emblemática destruição das cidades e de seus habitantes definir-se-ia pela pretensão daqueles homens de violentar sexualmente os hóspedes de Ló; ou seja, sua devassidão sexual. Essa leitura, atualmente controvertida, se ancora numa singular interpretação da passagem em que os sodomitas exigem "conhecer" os homens abrigados por Ló, atribuindo ao verbo hebraico yadha (conhecer) uma conotação sexual que se faz ausente na grande maioria de suas aparições nos textos bíblicos ${ }^{58}$ — em algumas traduções, lê-se até mesmo: "Traga-os para nós aqui fora para que tenhamos relações com eles"

Segundo Fone, no entanto, é mais coerente sustentar que, pelo próprio contexto histórico da narrativa, o grave pecado daqueles homens seria a ofensa, pela ameaça de agressão, sexual ou não, à regra de hospitalidade para com viajantes, uma tradição bastante valorizada pelos povos do período. Esse entendimento parece ser corroborado pela advertência de Ló aos sodomitas, antevendo o risco a seus hóspedes: "Mas não façam nada a estes homens, porque eles se hospedaram sob o meu teto "60. A leitura anti-homossexual de Sodoma, entretanto, ganhou impulso com a abordagem que lhe fora conferida por escritores judeus, nos dois últimos séculos antes de Cristo, tomando por base de sua interpretação as orientações inscritas em

\footnotetext{
57 BÍBLIA. Espanhol. El libro del pueblo de Dios: La Biblia. Disponível em: <http://www.vatican.va/archive/ESL0506/_INDEX.HTM>. Acesso em 06/04/2016

${ }^{58}$ FONE, Byrne. Homophobia: a history. Nova York: Picador, 2000, p. 75-79.

59 BÍBLIA. Português. Nova Versão Internacional. Disponível em: $<$ http://www.biblica.com/es-us/la-biblia/>. Acesso em 06/04/2016.

${ }^{60}$ BÍBLIA. Espanhol, op. cit.
} 
Levítico. No novo testamento, por outro lado, a reprovabilidade expressa aos atos homoeróticos se resumem, basicamente, à parte das cartas do apóstolo Paulo ${ }^{61}$.

De todo modo, não obstante as importantes indefinições doutrinárias que enfrentava, o cristianismo primitivo já era firme na rejeição às relações homoeróticas, como deletérias à instituição do matrimônio e antinaturais, pervertendo os desígnios divinos para o homem e para a mulher, voltados à procriação. Posições contundentes sobre a moral sexual e em rejeição à homossexualidade partiram, por exemplo, de Agostinho de Hipona (354-450 DC). Sua obra, invocando o desprezo e o castigo eterno contra os sodomitas, pecadores contra a natureza, exerceria grande influência na doutrina da Igreja Católica do Ocidente ${ }^{62}$.

O fato é que o epíteto sodomita, pelos séculos que viriam, serviu para acusar os que incorriam em toda sorte de condutas sexuais consideradas aberrantes - não destinadas à procriação e/ou praticadas fora da relação matrimonial. O transcurso do tempo, porém, fez com que a abrangência semântica do termo fosse se restringindo, para se associar quase que exclusivamente às práticas homoeróticas ${ }^{63}$.

A paulatina expansão da fé cristã, com a promessa de salvação restrita a seus adeptos, foi consolidando, ao longo de gerações, uma mudança de perspectiva em torno de comportamentos homossexuais outrora amplamente aceitos; inclusive e principalmente, com a adesão das elites políticas ${ }^{64}$.

Com a cristianização do Império Romano, durante os reinados de Constantino II e Constâncio I, por volta de 342 DC, introduziram-se as primeiras sanções legais aos acusados de envolvimentos em práticas homoeróticas. Já em 390, o Código Teodosiano estabeleceu a condenação à fogueira por atos de homossexualidade passiva. As punições foram se agravando, ao ponto em que, em 533, Justiniano veio a generalizar a pena de morte para os incursos em condutas homoeróticas ${ }^{65}$.

O componente demográfico, segundo observa Vecchiatti, também pesou para o recrudescimento da opinião pública em face do sexo não reprodutivo. Taxas altas de natalidade, afinal, eram necessárias para manter estáveis o níveis populacionais

\footnotetext{
${ }^{61}$ FONE, Byrne. Homophobia: a history. Nova York: Picador, 2000, p. 81-100.

62 Ibid., p. 106.

63 Ibid., p. 175.

${ }^{64}$ VECCHIATTI, Paulo Roberto lotti. Manual da homoafetividade: da possibilidade jurídica do casamento civil, da união estável e da adoção por casais homoafetivos. São Paulo: Método, 2012, p. 21-22.

${ }^{65}$ FONE, op. cit., p. 110-115.
} 
do Império, durante a fase de expansão do cristianismo, tendo em vista o surgimento de epidemias, como a da peste bubônica, e o constante envolvimento de Roma em guerras - motivo pelo qual as relações entre pessoas do mesmo sexo, biologicamente inviáveis para a procriação, seriam desestimuladas ${ }^{66}$.

O autoritarismo crescente na fase de declínio do Império Romano, a partir do século III da Era Comum, com um endurecimento sancionador no tocante ao homoerotismo, não refletia uma motivação etnocêntrica como a dos hebreus em face da homossexualidade, exibindo, pelo contrário, traços de um preconceito de viés obsessivo, avesso à antiga celebração narcisista e falocêntrica das relações de paiderastia. Homossexuais tornaram-se, desse modo, uma ameaça fictamente articulada em prol da destruição do Império ${ }^{67}$.

Nos séculos seguintes à queda de Roma, a Igreja Católica se expandiu e, com ela, a postura de rejeição às práticas homoeróticas. Sem embargo, do início do medievo até, aproximadamente, os séculos XI e XII, observou-se relativa complacência ao homoerotismo. Alguns textos do início do medievo, aliás, celebravam relações de intensa amizade entre pessoas do mesmo sexo — inclusive física ${ }^{68}$.

A despeito da existência de diplomas normativos repressivos desde o final do Império Romano, passando pelos primeiros séculos do Medievo, há um certo consenso, porém, de que essas legislações foram, em geral, episódicas e de baixa eficácia. O recrudescimento efetivo na aplicação da lei contra os homossexuais deuse no contexto de afirmação da Igreja, em meio às reformas eclesiásticas iniciadas por volta do século XI, paralelamente ao fortalecimento das monarquias feudais e à expansão do cristianismo por meio das cruzadas ${ }^{69}$.

Nos séculos XIII e XIV, eleva-se a sodomia ao rol dos pecados mais graves, um "vício máximo contra natura", com forte associação ao sexo anal, em função da inversão de papéis sexuais, e aproximação ao bestialismo. Por volta de 1265, Tomás de Aquino, em sua Suma Teológica, repisa esse ideário, destacando a prática sexual entre homens ou entre mulheres como manifestação perfeita da sodomia, o ápice da

\footnotetext{
${ }^{66}$ VECCHIATTI, Paulo Roberto lotti. Manual da homoafetividade: da possibilidade jurídica do casamento civil, da união estável e da adoção por casais homoafetivos. São Paulo: Método, 2012, p. 23.

${ }^{67}$ YOUNG-BRUEHL, Elisabeth. The anatomy of prejudice. Cambridge: Harvard University Press, 1996, p. 438.

${ }^{68}$ FONE, Byrne. Homophobia: a history. Nova York: Picador, 2000, p. 127-140.

${ }^{69}$ Ibid., p. 132-140.
} 
luxúria e uma abominável subversão do uso natural do sexo ${ }^{70}$. De outro ângulo, tratouse de período economicamente conturbado e acometido pelas graves consequências da peste bubônica - condições propícias ao fortalecimento de preconceitos obsessivos $^{71}$.

Foi igualmente nessa época que a persecução jurídica ao homoerotismo, no âmbito do Direito Comum, se intensificou. Os incursos em atos de sodomia, pecadores do ponto de vista cristão, tornaram-se, aos olhos do Estado, também criminosos e socialmente perigosos, ficando sujeitos a toda sorte de sanções: da castração à pena capital, na forca ou na fogueira. Diplomas normativos com esse escopo se multiplicaram pelo continente Europeu. Na França, preceitos dessa natureza constavam do Livre de Justice et de Plet, de 1260, e no Coutumes de Beauvaisis, de 1283. Na Espanha, tinha-se o Código Las Siete Partidas, de 1265. Na Inglaterra, tratados como o Britton e o Fleta convergiam com legislações de cidades italianas como Bolonha, Florença e Perugia ${ }^{72}$.

Além de uma eficiente arma em disputas políticas (contra monarcas e papas, inclusive), a acusação de sodomia era frequentemente acionada contra os supostos inimigos da civilização latino-cristã: minorias étnicas, a exemplo dos Judeus; e adeptos de outras crenças religiosas, como a islâmica. Insinuações nesse sentido fizeram parte da estratégia empregada pelo Rei Felipe IV, da França, para desacreditar e extinguir a poderosa ordem dos Cavaleiros Templários, no início do século XIV, confiscando seus bens ${ }^{73}$.

Dada a já disseminada ideia de vinculação das relações entre pessoas do mesmo sexo à propagação de doenças e infecções ${ }^{74}$, a associação dos chamados Atos de Sodomia com a disseminação da peste negra, na Europa medieval, foi outro fator que contribuiu para inflamar o pânico e propagar posturas anti-homossexuais ${ }^{75}$.

$\mathrm{Na}$ fase do Renascimento, o homoerotismo já era alardeado tanto como ameaça concomitante ao Estado, à Igreja e à sociedade, quanto como fonte de epidemias e catástrofes a ser combatida e severamente punida. É importante frisar,

\footnotetext{
${ }^{70}$ VAINFAS, Ronaldo. O nefando e a colônia. In: Trópico dos pecados: moral, sexualidade e inquisição no Brasil. Rio de Janeiro: Nova Fronteira, 1997, p. 154-159.

${ }^{71}$ FONE, Byrne. Homophobia: a history. Nova York: Picador, 2000, p. 132-140.

72 Ibid., p. 143-144.

${ }^{73}$ lbid., p. 148-155.

${ }^{74}$ Lembrando que a própria sodomia, em si, fora relatada ao longo da história como um mal contagioso.

${ }^{75}$ FONE, op. cit., p. 186-187.
} 
contudo, que, a despeito dessa estrutura repressiva, o resgate e a celebração da Antiguidade clássica pelos renascentistas permitiram algum grau de abertura aos sentimentos homoeróticos, nos moldes de uma idealizada amizade masculina, que bebia da fonte das relações de pederastia greco-romanas. Na literatura e nas artes visuais, a menção a esses laços masculinos de amor frequentemente eram vinculados ao mito de Ganímedes, segundo o qual Zeus, encantado pela beleza do rapaz troiano, assume a forma de uma águia para raptá-lo, levando-o consigo para o Olimpo ${ }^{76}$.

As dissidências de matiz religioso que emergiram com a Reforma Protestante no século XVI fizeram agravar o desapreço contra a homossexualidade. De um lado, as novas correntes religiosas condenavam a Igreja Católica Apostólica Romana por práticas reputadas contrárias ao verdadeiro cristianismo (a exemplo do celibato dos sacerdotes) e que supostamente ensejariam o crescimento da sodomia; de outro, o movimento de Contrarreforma da Igreja Católica, reafirmando os principais pilares de sua doutrina (como a santidade do matrimônio, por exemplo), se voltou com maior ênfase ao combate ao homoerotismo ${ }^{77}$. Em uma terceira frente, os Estados europeus, insuflados pelo discurso moralista-religioso do momento, reforçaram a perseguição a homossexuais, inclusive no plano legislativo. Em Portugal, por exemplo, a sodomia passou a ser classificada como crime de lesa-majestade, sujeito à pena de morte e à apropriação dos bens do condenado, estendendo-se a infâmia a seus descendentes ${ }^{78}$.

Esse ímpeto persecutório era, porém, seletivo: os julgamentos, condenações e execuções recaíram majoritariamente sobre trabalhadores vulneráveis, artesãos e desapossados. A nobreza, por sua vez, gozava de bem mais ampla liberdade sexual e tolerância das autoridades civis e religiosas. ${ }^{79}$

A história da homossexualidade e da homofobia na tradição ocidental, entretanto, não se cingiu ao Velho Continente. Ao aportarem na América no final do século $\mathrm{XV}$, trazendo consigo o mito de Sodoma, os europeus se depararam com múltiplas práticas culturais, de povos nativos, com viés homoerótico ou transgressor à partição social binária de gêneros. Há, por exemplo, relatos de indígenas que, no dia a dia, se portavam como se pertencessem ao sexo oposto ou a um terceiro gênero

\footnotetext{
${ }^{76}$ FONE, Byrne. Homophobia: a history. Nova York: Picador, 2000, p. 179-183.

77 Ibid., p. 188-189.

${ }^{78}$ VAINFAS, Ronaldo. O nefando e a colônia. In: Trópico dos pecados: moral, sexualidade e inquisição no Brasil. Rio de Janeiro: Nova Fronteira, 1997, p. 161.

${ }^{79}$ Ibid., p. 161.
} 
- alguns dos quais ocupando posições de prestígio em suas respectivas comunidades. Esse costume foi documentado, entre outros, por Álvar Nuñez Cabeza de Vaca e pelo jesuíta Jacques Marquette, entre os séculos XVI e XVII ${ }^{80}$.

A presença do "pecado nefando" no Novo Mundo e a necessidade de sua eliminação acabaram se tornando uma das justificativas para o pretenso direito dos colonizadores sobre as novas terras e seus habitantes. Esse argumento foi invocado, por exemplo, na execução de centenas de indígenas panamenhos da vila de Quarequa, por ordem de Vasco Nuñez de Balboa, em 1513; e na violenta incursão de Hernán Cortéz na região do atual México, insurgindo-se contra a alegada prática instituída de sodomia dos astecas ${ }^{81}$. A aversão ao homoerotismo fez-se, ainda, especialmente intensa por parte dos puritanos ingleses, na América do Norte, que incluíram a sodomia no estrito rol de crimes passíveis de condenação à morte, desde os primeiros anos de colonização ${ }^{82}$.

Mais ao sul, nas regiões ocupadas pelos portugueses, o homoerotismo, embora alvo de condenação moral e religiosa, encontrava um cenário particularmente propício às suas manifestações. Se, de um lado, atos de sodomia seriam cometidos pelos colonizadores também em terras tropicais, de outro, práticas culturais homoeróticas de povos indígenas, como tupinambás, tupinaés, guaicurus, botocudos, bororos e ianomâmis, foram largamente documentadas ${ }^{83}$. O homoerotismo era, ainda, usual para determinados grupos africanos trazidos ao Brasil pelo tráfico negreiro, como no caso de nativos angolanos. A esses fatores, somou-se a frouxidão do controle eclesiástico e estatal, bem como a disparidade no número de homens e mulheres, nos primeiros tempos da colônia. Sobre o tema, pondera Luiz Mott:

Praticado livremente pelos brasis autóctones e pelos africanos que para cá vieram trazidos, praticada clandestinamente em Portugal pelos lusitanos, mouros e judeus, o homossexualismo encontrou no Brasil quinhentista condições as mais favoráveis para seu florescimento. Imbuídos da idéia de que "abaixo do Equador não há pecado", favorecidos pela imensidão da terra e falta de controle policial e moral, beneficiados pela situação colonial que conferia aos brancos o direito legítimo de usar (e abusar) dos negros e índios seus escravos, e finalmente, considerando o desequilíbrio dos sexos que marcou longos períodos do Brasil de antanho (...), só nos resta

\footnotetext{
${ }^{80}$ FONE, Byrne. Homophobia: a history. Nova York: Picador, 2000, p. 322.

${ }^{81}$ Ibid., p. 319-321.

82 lbid., 2000, p. 331-332.

83 TREVISAN, 2004 apud VECCHIATTI, Paulo Roberto lotti. Manual da homoafetividade: da possibilidade jurídica do casamento civil, da união estável e da adoção por casais homoafetivos. São Paulo: Método, 2012, p. 34.
} 
concluir que a "Terra dos Papagaios" era ambiente muito favorável ao desenvolvimento de expressões sexuais mais livres e criativas ${ }^{84}$.

Não obstante os portugueses trouxessem consigo uma bagagem históricocultural que regulava a vivência do afeto e da sexualidade - notadamente, em favor da promoção do modelo familiar matrimonial cristão, monogâmico e voltado à reprodução, como forma de atribuição de status e segurança a seus membros ${ }^{85}$-, uma persecução mais expressiva aos homossexuais veio a se impor apenas quando o movimento inquisitorial da Igreja, em Portugal, voltou sua atenção à colônia, em meados do século $X \mathrm{VI}^{86}$.

Os arquivos do Tribunal do Santo Ofício, referentes às visitações ao Brasil entre os séculos XVI e XVIII, são uma rica fonte para melhor se compreender a vivência do homoerotismo no período colonial. Os livros da Inquisição versam, em detalhes, sobre a investigação de mais de uma centena de casos de sodomia nas meras três visitações realizadas. Desses registros, extrai-se que, muito embora os homossexuais não tenham chegado a constituir subculturas no Brasil colonial, como ocorrera em partes da Europa, existiam em significativo número, englobando todos os níveis da hierarquia social: solteiros, casados, jovens, velhos, senhores de engenho, índios, escravos, nascidos em Portugal ou em terras brasileiras ${ }^{87}$.

Sobre a experiência homoerótica na colônia, Ronaldo Vainfas acrescenta que, dadas as condições do espaço doméstico, os atos sexuais, não raro, eram praticados em locais públicos:

Seja como for, a casa longe estava de ser o espaço privilegiado para as relações sexuais, sobretudo se fossem relações ilícitas. Os sodomitas, por exemplo, foram pegos em navios, nas oficinas de trabalho, nos engenhos, no mato. O mato, com efeito, parece ter sido espaço muitíssimo frequentado pelos amantes ilícitos ou eventuais, sendo também muito referido nos casos heterossexuais dos colonos que copulavam com índias. Colônia de poucas cidades e casas devassadas, o Brasil teria nos matos ("em cima das ervas") um espaço de deleitações, especialmente, insisto, no caso de relações proibidas. Grande paradoxo: um espaço, por assim dizer, público, como era o mato ou a beira do rio, podia ser mais apto à privacidade exigida por

\footnotetext{
${ }^{84}$ MOTT, Luiz. Relações raciais entre homossexuais no Brasil colônia. Revista brasileira de história, São Paulo, v.5, n.10, p. 99-122, mar./ago. 1985, p. 104.

${ }^{85}$ PRIORE, Mary Del. História do amor no Brasil. São Paulo: Contexto, 2005, p. 22-23.

${ }^{86}$ VAINFAS, Ronaldo. O nefando e a colônia. In: Trópico dos pecados: moral, sexualidade e inquisição no Brasil. Rio de Janeiro: Nova Fronteira, 1997, p. 166-169.

${ }^{87}$ Ibid., p. 166-169.
} 
intimidades secretas do que as próprias casas de parede-meia ou cheias de frestas" 88 .

Em que pese ocorressem de norte a sul do território brasileiro, as relações homoeróticas iam de encontro às normas morais e jurídicas vigentes. A ingerência do Estado e da religião, na vida dos habitantes do Brasil colonial e do Império, tinha em mira a promoção de um modelo social embasado nas famílias de padrão matrimonial católico, condenando comportamentos que, apesar de recorrentes, se afastassem desse parâmetro. Privilegiava-se um modelo familiar extenso e patrimonializado, com estrutura hierárquica e patriarcal, típico de uma sociedade eminentemente rural, em que a prole numerosa representava incremento de força produtiva ${ }^{89}$. A industrialização e a urbanização tardias do Brasil seriam fatores relevantes para que a compreensão da homossexualidade passasse por transformações ocorridas, anos antes, em países centrais do continente europeu e na América do Norte.

\subsubsection{A construção moderna da persona homossexual}

A partir do século $\mathrm{XVIII}$, os ideais encampados pelo lluminismo e pela Revolução Francesa delinearam o início de uma mudança no tratamento da homossexualidade, dando ensejo à descriminalização progressiva dos comportamentos homoeróticos - não acompanhada, porém, de um proporcional arrefecimento na intolerância social já disseminada em torno da questão. A luta em prol das liberdades individuais, afinal, não se compatibilizava com a penalização de atos sexuais consentidos entre cidadãos adultos.

A abolição do crime de sodomia foi encampada pela Assembleia Constitucional francesa de 1791 e reafirmada no Código Napoleônico de 1804. Reproduziu-se, ainda, em Estados como Portugal, Espanha, Prússia, Rússia, Bélgica e Itália. Embora a medida contasse com o apoio de nomes como o do filósofo Jeremy Bentham, a Inglaterra foi exceção a essa tendência, mantendo seus antigos estatutos e punições, com poucas alterações - principalmente em função do moralismo exacerbado da Era Vitoriana. Entre as vítimas notórias da Coroa britânica, o escritor

\footnotetext{
${ }^{88}$ VAINFAS, Ronaldo. Moralidades brasílicas: deleites sexuais e linguagem erótica na sociedade escravista. In: NOVAIS, Fernando A.; MELLO E SOUZA, Laura de. História da vida privada no Brasil: cotidiano e vida privada na América portuguesa. v. 1. São Paulo: Companhia das Letras, 1997, p. 257.

${ }^{89}$ DIAS, Maria Berenice de. Manual de Direito das Famílias. 6. ed., rev., atual. e ampl. São Paulo: Editora Revista dos Tribunais, 2010, p. 28.
} 
Oscar Wilde foi condenado em julgamento de grande repercussão, na década de 1890. Neste período, também, Lorde Alfred Douglas, amante de Wilde, redigiu o poema Two Loves, imortalizando a referência ao desejo entre pessoas do mesmo sexo como o "amor que não ousa dizer seu nome"

O período compreendido entre meados do século XVIII e início do século XIV, foi marcado pela sedimentação da sociedade capitalista e, bem assim, do modelo familiar burguês. A partir de então, segundo Foucault, com fortes incitações políticas, econômicas e técnicas, "há uma verdadeira explosão discursiva" em torno e a propósito do sexo - não mais um discurso de índole exclusivamente moral, mas que se pretende revestido de racionalidade ${ }^{91}$. Nessa nova articulação entre poder, saber e sexo, "cumpre falar do sexo como de uma coisa que não se deve simplesmente condenar ou tolerar, mas gerir, inserir em sistemas de utilidade, regular para o bem de todos, fazer funcionar segundo o padrão ótimo"92.

Nesse intento racionalizante, a questão do sexo se desloca para o foco das atenções médico-científicas. Observa-se um esforço concentrado na produção de verdades a esse respeito, com pesquisas, análises e classificações que, a partir do estabelecimento de um parâmetro de normalidade heterossexual e monogâmico, dedicaram-se, com maior afinco, a esmiuçar as expressões da sexualidade supostamente desviantes - as aberrações e as perversões. A neutralidade dessa nova fonte de verdades quanto ao sexo, entretanto, era apenas aparente, visto que, ao traduzir para o discurso médico os preconceitos e as normas sociais preexistentes, conformava "uma ciência essencialmente subordinada aos imperativos de uma moral"93, submissa às opiniões dominantes.

Os procedimentos de produção da verdade dessa scientia sexualis, segundo Foucault, ordenam-se essencialmente em torno dos mecanismos de confissão. Extraída de uma relação de poder, o confidente é também o objeto de sua fala, a qual será apreciada pelo interlocutor que, ao fim, inocenta, pune, perdoa, purifica ou indica o caminho para a recuperação. Transposta ao âmbito médico e examinada pelo

\footnotetext{
${ }^{90}$ FONE, Byrne. Homophobia: a history. Nova York: Picador, 2000, p. 265-272.

${ }^{91}$ FOUCAULT, Michel. História da sexualidade I: a vontade de saber. Rio de Janeiro: Edições Graal, 1988, p. 21.

${ }^{92}$ Ibid., p. 27.

93 lbid., p. 54.
} 
responsável por revelar a verdade sobre o sexo, a confissão resulta em um diagnóstico que a insere no regime do normal ou do patológico ${ }^{94}$.

Se, até então, predominava o entendimento de que existiria um sexo único, masculino, detentor de todas as potencialidades, e de que a mulher seria nada mais que uma versão inferior e invertida do homem; no limiar do século XVIII, ganha espaço a noção de sexos opostos e complementares, uma divisão binária entre o sexo do homem e o da mulher, mas que se prestou também a legitimar as diferentes expectativas traçadas para o masculino e para o feminino na nova ordem social e política em ascensão. Nesse impulso discursivo, mobilizando o sexo como instrumento de poder, cunhou-se, pela naturalização de construções de gênero, uma diferenciação de status político, jurídico e moral para homens e mulheres, com seus respectivos papéis e lugares predeterminados ${ }^{95}$.

Dessa convergência entre ciência e moral, erigiu-se como verdade natural a relação entre homem e mulher e o modelo de família nuclear burguesa predominante, atribuindo-se às práticas homoeróticas, por conseguinte, o estigma do desvio. Em uma época em que as ideias evolucionistas de Charles Darwin gozavam de amplo prestígio e popularidade, o desejo por pessoas de mesmo sexo seria compreendido como necessariamente patológico, por ensejar a formação de relações estéreis ${ }^{96}$.

A pecha da inversão, outrora explicativa do ser mulher, passou a ser associada ao indivíduo com inclinações para o homoerotismo, uma perversão caracterizada pelo desvio de caráter e pela degeneração moral em relação às práticas sexuais então reputadas naturais e sadias ${ }^{97}$. Proliferavam-se terapias e tratamentos, visando a curar as inclinações dos degenerados ${ }^{98}$.

Por meio desses discursos que traçam um elo falacioso entre biologia e prescrições morais, a vivência do sexo e as performances de gênero são essencializadas, inscritas numa ordem que relega à clandestinidade corpos e projetos de vida que não se enquadram ao manual da existência de uma família burguesa ideal:

94 FOUCAULT, Michel. História da sexualidade I: a vontade de saber. Rio de Janeiro: Edições Graal, 1988, p. 66.

${ }^{95}$ CECCARELLI, Paulo Roberto; FRANCO, Samuel. Homossexualidade: verdades e mitos. Bagoas: Revista de Estudos Gays, v. 5, 2010, p. 122.

96 BORRILLO, Daniel. Homofobia: história e crítica de um preconceito. Belo Horizonte: Autêntica Editora, 2010, p. 65.

${ }^{97}$ CECCARELLI, op. cit., p. 123.

${ }^{98}$ Ibid., p. 124. 
(...) a materialidade do corpo determina o papel social que aquele indivíduo deve desempenhar. Do menino, espera-se que desenvolva hábitos e comportamentos masculinos $e$, da menina, hábito $e$ comportamentos femininos. Qualquer desvio desse padrão é logo entendido como patologia ${ }^{99}$.

É sintomático, aliás, que o conceito de homossexualidade tenha sido cunhado nesse momento histórico, que conjugou a despenalização das relações homoeróticas à medicalização do tema. A palavra surgiu entre os anos de 1868 e 1869, em um panfleto elaborado pelo austro-húngaro Karl-Maria Kertbeny, em teor de crítica à persecução estatal aos homossexuais, contrapondo Homosexualität à Normalsexualität, isto é, ao conjunto de práticas sexuais da grande maioria da população ${ }^{100}$.

A expressão homossexual, todavia, logo foi integrada ao discurso médico para designar, com perfeição, esse novo constructo moderno, um indivíduo com inclinações sexuais particulares e exóticas que lhe eram inerentes, distanciado da imagem do antigo sodomita, um sujeito qualquer que infringia a interdição religiosa ou penal e, por isso, era considerado pecador ou criminoso ${ }^{101}$.

O homossexual, segundo esclarece Foucault, emerge como uma nova categoria, um terceiro sexo a ser minuciosamente explorado:

Esta nova caça às sexualidades periféricas provoca a incorporação das perversões e nova especificação dos indivíduos. A sodomia - a dos antigos direitos civil ou canônico - era um tipo de ato interdito e o autor não passava de seu sujeito jurídico. O homossexual do século XIX torna-se uma personagem: um passado, uma história, uma infância, um caráter, uma forma de vida; também é morfologia, com uma anatomia indiscreta e, talvez, uma fisiologia misteriosa. Nada daquilo que ele é, no fim das contas, escapa à sua sexualidade. Ela está presente nele todo: subjacente a todas as suas condutas, já que ela é o princípio insidioso e infinitamente ativo das mesmas; inscrita sem pudor na sua face e no seu corpo já que é um segredo que se trai sempre. É-lhe consubstancial, não tanto como pecado habitual, porém como natureza singular. É necessário não esquecer que a categoria psicológica, psiquiátrica e médica da homossexualidade constituiu-se no dia em que foi caracterizada - o famoso artigo de Westphal em 1870 , sobre as "sensações sexuais contrárias" pode servir de data natalícia - menos como um tipo de relações sexuais do que como uma certa qualidade da sensibilidade sexual, uma certa maneira de interverter, em si mesmo, o masculino e o feminino. A homossexualidade apareceu como uma das figuras da sexualidade quando foi transferida, da prática da sodomia, para uma espécie de

\footnotetext{
${ }^{99}$ MOREIRA, Adailson. A homossexualidade no Brasil no século XIX. Bagoas: Revista de Estudos Gays, v. 7, 2012, p. 270-271.

${ }^{100}$ FONE, Byrne. Homophobia: a history. Nova York: Picador, 2000, p. 4.

101 Ibid., 2000, p. 275.
} 
androgenia interior, um hermafroditismo da alma. O sodomita era um reincidente, agora o homossexual é uma espécie ${ }^{102}$.

Se, nos séculos que antecederam essa guinada, a atração ou as práticas sexuais de uma pessoa não eram compreendidas como se lhe fossem estruturantes ou inerentes; a partir de então, como uma inédita armadura identitária, fixou-se a repartição binária e antagônica para a vivência do sexo (homossexual v. heterossexual) ${ }^{103}$, dando forma ao que Ceccarelli considera um artefato classificatório $^{104}$ :

Os critérios que determinam a forma "correta" do exercício da sexualidade, construídos e historicamente datados, são arranjos simbólicos que repousam sobre o sistema de valores de uma dada sociedade. Na sociedade ocidental, dominada pela tradição judaicocristã, esse simbólico é marcado por uma visão negativa da sexualidade, cujas origens devem ser buscadas no relato bíblico do pecado original (...). Foram também os ideais da cultura ocidental que deram origem ao discurso que classifica as práticas sexuais em "normais" e "anormais" (ou perversas, desviantes). A partir da idéia de uma sexualidade normal segundo a natureza, todo desvio passa a ser considerado uma depravação (...) "contra a natureza". Quando a sexualidade desvia da finalidade primeira - união de dois órgãos sexuais diferentes para a preservação da espécie -, estamos diante de uma perversão: pedofilia, necrofilia, masturbação, heterossexualidade separada da procriação, homossexualidade, sodomia... ${ }^{105}$.

Entre o final do século XIX e começo do século XX, a questão homossexual tornou-se objeto de estudo também da Psicanálise. Voz dissonante à época, mas de suma importância para a futura superação da abordagem patológica da homossexualidade, Sigmund Freud debruçou-se repetidamente sobre o tema, em trabalhos como "Os três ensaios sobre a sexualidade", de 1905, ou "O caso Schreber", de $1911^{106}$.

A despeito de interpretações controvertidas em torno da obra do psicanalista, para Ceccarelli, tanto a homossexualidade quanto a heterossexualidade, em Freud,

102 FOUCAULT, Michel. História da sexualidade I: a vontade de saber. Rio de Janeiro: Edições Graal, 1988, p. 43-44.

103 LIMA, Suzana Borges Viegas de. O estatuto jurídico das relações homoafetivas. Brasília: Gazeta Jurídica, 2015, p. 11.

${ }^{104}$ CECCARELLI, Paulo Roberto. A invenção da homossexualidade. Bagoas: Revista de Estudos Gays, v. 2, 2008, p. 73.

${ }^{105}$ Ibid., p. 86-87.

${ }^{106}$ Cf. FREUD, Sigmund. Observações psicanalíticas sobre um caso de paranoia relatado em autobiografia: ("O caso Schreber"): artigos sobre técnica e outros textos (1911-1913). São Paulo: Cia. das Letras, 2010; FREUD, Sigmund. Trois essais sur la théorie de la sexualité. Paris: Gallimard, 1987. 
seriam objetos pulsionais igualmente legítimos, não representando a mera condição de homossexual um diferencial positivo ou negativo ${ }^{107}$.

Segundo Ceccarelli, na perspectiva freudiana, a finalidade primeira da sexualidade é o prazer e não a reprodução, escapando, desse modo, ao enclausuramento em supostos padrões naturais. Nesse quadro, a homossexualidade seria uma possibilidade de investimento libidinal tal qual a heterossexualidade - um dos diversos destinos da pulsão sexual humana, no contexto da resolução edipiana. Não haveria, em essência, uma identidade homossexual, mas apenas investimentos pulsionais direcionados a uma variedade de objetos, se expressando no que se identifica por orientações sexuais. Essa seria a razão pela qual homossexuais não seriam doentes, nem um problema a ser tratado na esfera penal ${ }^{108}$.

Entretanto, a abordagem mais complacente em relação à homossexualidade não era consensual, despertando polêmicas, até mesmo, no tocante à possiblidade de que homossexuais fossem admitidos como psicanalistas. A própria filha de Sigmund Freud, Anna Freud, engajou-se, na prática clínica, em tentativas de conversão de pessoas homossexuais à heterossexualidade. Outrossim, para a corrente da psicanálise ligada à Melanie Klein, consentânea ao discurso hegemônico normalizante do período, a homossexualidade consistiria em uma grave patologia ${ }^{109}$.

Em que pese uma mudança no tratamento dispensado ao sexo caminhasse a passos largos, nos países europeus, desde o século XVIII, tardaria um pouco para repercutir em terras brasileiras. Como ressalta Adailson Moreira, o Brasil de contornos coloniais, patriarcal e majoritariamente iletrado, não sofreria grandes abalos nesse campo até o ingresso no século $\mathrm{XIX}^{110}$.

Nesses cem anos que seguiram, todavia, o país alcançou a independência, tornou-se um império e, décadas depois, uma república. Viu também ruir a tradição escravocrata, com o desmonte de seu suporte legal, e a criação de entidades de ensino que viriam a formar suas elites políticas. Em meio à ebulição social e intelectual, se disseminaram os ideais, os valores e o modo de vida burgueses europeus, bem como as teorias científicas e higienistas que, ancoradas no discurso

${ }^{107}$ CECCARELLI, Paulo Roberto; FRANCO, Samuel. Homossexualidade: verdades e mitos. Bagoas: Revista de Estudos Gays, v. 5, 2010, p. 125.

108 lbid., p. 75-76.

109 lbid., p. 77-78.

${ }^{110} \mathrm{Cf}$. MOREIRA, Adailson. A homossexualidade no Brasil no século XIX. Bagoas: Revista de Estudos Gays, v. 7, p. 253-279, 2012. 
da normalidade, voltariam a atenção aos domínios do sexo, vertendo prescrições à experimentação da sexualidade e estudando, com um nítido olhar de censura, os comportamentos considerados desviantes. No curso do século XIX, a homossexualidade, também no Brasil, tornou-se um "distúrbio" a instigar pesquisadores em busca de curas, tratamentos e explicações ${ }^{111}$.

De forma geral, o que se destaca, em relação a esse novo preconceito antihomossexual que emergia no Ocidente, é que, ao contrário dos períodos anteriores marcadamente obsessivos, como o do ascetismo cristão, ou de forte ansiedade fáliconarcisista diante da efeminação do homem - que se voltavam, essencialmente, para o fazer do sujeito - ; a construção da figura homossexual, no final da década de 1860, ilustra o início de uma fase em que o enfoque orexista tem em mira o ser, isto é, estrutura-se ao redor de demarcações identitárias. Esse espécime particular seria considerado inferior, menor em dignidade diante dos autointitulados normais, nos moldes de um preconceito histérico que enfatizava o lugar marginal do desviante na sociedade $^{112}$.

A hipocrisia histérica dessa nova concepção é também perceptível: a afirmação de que os homossexuais constituem uma espécie distinta e monstruosa (um mal de que, supor-se-ia, as demais pessoas estariam a salvo) contradiz a simultânea assertiva de que a homossexualidade seria, de algum modo, transmissível ou contagiosa, devendo ser mantida à distância. Sob a demarcação da diferença, subjaz um medo da igualdade quanto aos desejos compartilhados: temer o homossexual é temer o desejo homoerótico que pode existir dentro de si mesmo ${ }^{113}$.

$\mathrm{Na}$ vertente histérico-obsessiva desse discurso, disseminaram-se as falsas acusações que inter-relacionam homossexualidade e pedofilia, ou sustentam que homossexuais tendem a se infiltrar nos espaços usualmente frequentados por crianças e adolescentes, como as instituições educacionais, a fim de molestá-las ou cooptá-las para a homossexualidade ${ }^{114}$.

A partir dessa transição do pensamento ocidental, erigindo padrões de normalidade pretensamente científicos, que conformam uma heterossexualidade

\footnotetext{
${ }^{111}$ MOREIRA, Adailson. A homossexualidade no Brasil no século XIX. Bagoas: Revista de Estudos Gays, v. 7, p. 253-279.

112 YOUNG-BRUEHL, Elisabeth. The anatomy of prejudice. Cambridge: Harvard University Press, 1996, p. 445.

113 Ibid., p. 445-447.

114 lbid., p. 447-448.
} 
compulsória, esse preconceito de perfil majoritariamente histérico foi, aos poucos, se sedimentando e o discurso hostil a ele atrelado foi ganhando diversificadas vertentes.

Daniel Borrillo denomina ideologias homofóbicas o "conjunto das ideias que se articulam em uma unidade relativamente sistemática (doutrina) e com finalidade normativa (promover o ideal heterossexual)"115. A depender da inclinação dessas linhas de pensamento, seu projetos para lidar com a questão homossexual podem abranger a segregação do diferente, a sua "recuperação" (a anulação da diferença), ou até mesmo o seu extermínio ${ }^{116}$.

O século $X X$, em particular, comportou ideologias notadamente perniciosas às pessoas homossexuais, com destaque para a Alemanha nazista e para a antiga União das Repúblicas Socialistas Soviéticas - URSS ${ }^{117}$.

Contrastando com uma Berlim antes receptiva à diversidade sexual, com uma produção literária e intelectual favorável ao homoerotismo, o regime nazista que ascendeu ao poder na Alemanha, após a derrota sofrida na Primeira Guerra Mundial, tinha no ápice de seu sistema de valores a supremacia ariana. Num quadro de crise demográfica do pós-guerra, o sucesso desse projeto político tornava imprescindível o crescimento populacional, mantendo a celebrada "pureza biológica". A reprodução pretendida era, todavia, incompatível com a existências de anomalias, desvios e degenerações que pudessem ameaçar a supremacia alemã. Nesse contexto, grupos de pessoas como portadores de necessidades especiais e, por óbvio, homossexuais, entraram na mira do $3^{\circ}$ Reich. A contar da década de 1930 , se multiplicaram os estudos e experimentos, por vezes brutais, voltados à cura de homossexuais (incluindo, até mesmo, a cópula forçada com prostitutas). Concomitantemente, observou-se um endurecimento na repressão criminal ao homoerotismo, visto como ameaça ao mundo germânico. Criou-se, por exemplo, a "Agência Central do Reich para Combater a Homossexualidade e o Aborto". Constada, porém, a ineficácia dessas empreitadas, as soluções seguintes adotadas pelos expoentes do Nacional Socialismo foram igualmente violentas: a castração ou a efetiva eliminação dos homossexuais. As estimativas sugerem que algo em torno de 15.000 homossexuais tenham sido enviados para campos de concentração sob controle do Reich,

${ }^{115}$ BORRILLO, Daniel. Homofobia: história e crítica de um preconceito. Belo Horizonte: Autêntica Editora, 2010, p. 64.

${ }^{116}$ Ibid., p. 64-86.

117 Ibid., p. 78-86. 
ostentando em suas vestes o hoje simbólico triângulo cor-de-rosa que os identificava. Essas vítimas do nazismo, vale frisar, jamais receberam apoio financeiro ou reparação do Estado pelo sofrimento que Ihes foi imposto, uma vez que suas condutas permaneceram na ilegalidade por anos após a derrocada do regime ${ }^{118}$.

A retórica anti-homossexual se espraiava e se ramificava, na primeira metade do século $X X$, mesmo quando os diferentes discursos contradiziam uns aos outros. Se para boa parte dos intelectuais do Ocidente a homossexualidade consistia em desvio ou perversão, exatamente por inviabilizar o formato "normal" de família nuclear burguesa (matrimonial, heterossexual, monogâmico e calcado em papéis de gênero), para teóricos comunistas da União Soviética, o homoerotismo seria um vício característico da degenerescência capitalista e da decadência moral do estilo de vida burguês $^{119}$.

Em que pese algum grau de tolerância tenha se esboçado no alvorecer da Revolução Russa, a ideia de que a homossexualidade seria uma inclinação anormal da função sexual recorrente no capitalismo, mas inexistente na moralmente saudável sociedade soviética, foi encampada com vigor durante a era de Stálin, a partir do final da década de 1920. Essa guinada de posicionamento encontra-se refletida no verbete referente à homossexualidade constante da Grande Enciclopédia Soviética, quando se comparam as edições de 1930, que não reputava desviante o homoerotismo, e de 1952, na qual foi abordada como inclinação aberrante e contrarrevolucionária. Foi, com efeito, sob o stalinismo que a legislação penal foi modificada para prescrever, àqueles envolvidos em relações homoeróticas, a largamente aplicada sanção de até cinco anos de trabalhos forçados ${ }^{120}$.

Em síntese, até meados do século $X X$, fosse nos países de regime democrático, fosse em Estados de feições autoritárias; fossem nações adeptas ao capitalismo ou ao socialismo, a homossexualidade, excluída das categorias de normalidade, era em grande medida alvo de preconceitos articulados das formas mais distintas e, às vezes, paradoxais.

118 BORRILLO, Daniel. Homofobia: história e crítica de um preconceito. Belo Horizonte: Autêntica Editora, 2010, p. 82-86.

${ }^{119}$ Ibid., p. 78-81.

${ }^{120}$ lbid., p. 78-81. 


\subsection{4 "We're here, we're queer, get used to it!": os homossexuais saem do armário}

"If a bullet should enter my brain, let that bullet shatter every closet door" Harvey Milk

Em 1945, as fronteiras da normalidade heterossexual sofreram forte abalo com a publicação de uma extensa pesquisa conduzida pelo norte-americano Alfred Kinsey, sobre o comportamento sexual masculino. A despeito das críticas tecidas ao estudo, mormente no que tange à metodologia aplicada por Kinsey, que estruturou suas categorias a partir da observação de atos sexuais, em detrimento da análise do desejo sexual, o relatório teve o mérito de se distanciar do moralismo e do preconceito que ainda contaminavam as pesquisas em torno da sexualidade. De um lado, o estudo dedicou-se à análise da homossexualidade de forma direta e transparente, a despeito do tabu em torno do tema. De outro, mediante constatações como a de que, entre a adolescência e a velhice, $37 \%$ dos homens já vivenciaram alguma experiência homossexual $^{121}$, pôde demonstrar que a sexualidade masculina se manifesta numa multiplicidade de formas, um continuum de diferentes possibilidades, ao contrário das supostas identidades estanques, binárias e contrapostas (uma sadia e a outra desviante). A linha divisória entre o normal e o aberrante havia sido relativizada ${ }^{122}$.

Ao tempo dos primeiros questionamentos científicos mais incisivos ao tratamento da homossexualidade no campo das patologias, acelerava, no pósSegunda Guerra, o turbilhão de transformações sociais que exerceria influência fulcral nos capítulos seguintes da história do homoerotismo.

Na seara da vida privada, ocorria um processo de democratização paulatina das relações sociais. Com o definitivo ingresso da mulher no mercado de trabalho, numa fase de expansão econômica, e a explosão de movimentos sociais por igualdade e direitos civis, como o feminismo das décadas de 1960 e 1970, gradativas

\footnotetext{
${ }^{121}$ RIOS, Roger Raupp. O princípio da igualdade e a discriminação por orientação sexual: a homossexualidade no Direito brasileiro e norte-americano. São Paulo: Editora Revista dos Tribunais, 2002, p. 119.

${ }^{122}$ Em seu relatório, Kinsey catalogou as seguintes categorias: o "heterossexual exclusivo", o "incidentemente homossexual", o "mais do que incidentemente homossexual", o "igualmente hétero ou homossexual", o "mais do que incidentemente heterossexual", o "incidentemente heterossexual" e o "exclusivamente homossexual". Consultar: VECCHIATTI, Paulo Roberto lotti. Manual da homoafetividade: da possibilidade jurídica do casamento civil, da união estável e da adoção por casais homoafetivos. São Paulo: Método, 2012, p. 32-33.
} 
mudanças foram ocorrendo em uma organização social androcêntrica, moldada por papéis de gênero naturalizados ${ }^{123}$.

De outro lado, Zygmunt Bauman ressalta a flexibilização, no decorrer do século XX, da forma de relacionamento heterossexual matrimonial e perene representado pela família nuclear. Na chamada modernidade líquida, a lógica do custo-benefício se entranha também no campo dos relacionamentos interpessoais, tornando desinteressante, para muitos, o modelo de relação estável entre homem e mulher, oficializado pelo casamento. Comprometer-se é fechar-se para novas possibilidades de realização pessoal - segundo Bauman, um fardo particularmente pesado para o homem pós-moderno, que vive numa contínua busca pela satisfação imediata de desejos fugazes que, tão logo atendidos, são substituídos por novos objetivos. Na busca do prazer a curto prazo, o sexo casual e as relações mais flexíveis ganham espaço ${ }^{124}$. O parâmetro de normalidade insculpido no século XIX, na forma de uma conjugalidade heteronormativa, deixava de ser uma aspiração generalizada.

A dissolução de valores tradicionais que orientavam o mundo Ocidental, ao lado da supressão, no plano legislativo, da criminalização dos atos homoeróticos, conformou um cenário propício à vocalização dos anseios dessa parcela discriminada da população.

Por volta dos anos 1940 e 1950, surgiram os primeiros sinais de efetiva e articulada organização homossexual, nos Estados Unidos ${ }^{125}$. Paradoxalmente, a incessante perseguição do governo estadunidense aos homossexuais estimulou a criação e o fortalecimento dos movimentos em defesa dos direitos de gays e lésbicas, como a Mattachine Society, fundada em 1951. Todavia, dada a persistência da violência e da marginalização, bem como dos tratamentos médicos forçados e

\footnotetext{
${ }^{123}$ PRIORE, Mary Del. História do amor no Brasil. São Paulo: Contexto, 2005, p. 300-306. ${ }^{124}$ Cf. BAUMAN, Zygmunt. Amor líquido: sobre a fragilidade dos laços humanos. Rio de Janeiro: Zahar, 2004.

${ }^{125}$ Organizações em defesa dos direitos dos homossexuais já haviam sido criadas anteriores, na Alemanha, entre o fim do século XIX e o início do século $X X$, mas foram duramente reprimidas e o movimento, esvaziado, com o crescimento do movimento nazista. A esse respeito, Borrillo menciona as publicações homófilas Der Eigne e Sapho und Socrates; a criação do Comitê Científico-Humanitário (Wissens-chaftlich-humanitäres Komitee - WhK), em 1897, militando em favor dos direitos e do reconhecimento de gays e lésbicas; e a fundação, em 1919, do Instituto para a Ciência Sexual (Institut für Sexualwissenchaft), que viria a abrir a maior biblioteca sobre a temática homossexual à época. A respeito, consultar BORRILLO, Daniel. Homofobia: história e crítica de um preconceito. Belo Horizonte: Autêntica Editora, 2010, p. 84.
} 
experimentais, a grande maioria dos homossexuais, nos anos 1960, ainda preferia ocultar sua orientação sexual — isto é, "permanecer no armário"126.

Em 1969, porém, tem-se um novo impulso em favor de uma consistente organização dos homossexuais responsiva ao preconceito. Naquele ano, após uma batida policial no Stonewall Inn, conhecido ponto de encontro de homossexuais no bairro de Greenwich Village, em Nova York, os agentes estatais foram surpreendidos ao se depararem com forte reação da comunidade gay, aglomerada numa grande e hostil manifestação, que durou três dias, contrastando com a usual passividade e resignação. Pela primeira vez, nos Estados Unidos, homossexuais se uniram contra as forças que insistiam em tratá-los como cidadãos de segunda classe. Estava plantando o germe do ativismo gay contemporâneo, que iria se expandir vertiginosamente nas décadas seguintes ${ }^{127}$, manifestando-se tardiamente no Brasil $^{128}$.

Era chegada a hora de se esclarecer contra o quê esse movimento se erguia unido para lutar: um conjunto de posições e atos refratários à homossexualidade, que seria sintetizado na ideia de homofobia - termo cunhado, no início da década de 1970, por K. T. Smith e George Weinberg, para designar o "receio de estar com um homossexual em espaço fechado e, relativamente aos próprios homossexuais, o ódio por si mesmo"129.

\footnotetext{
${ }^{126}$ A metáfora do armário surge, à época, como alusão à necessidade de ocultação da própria identidade sexual, por gays e lésbicas, com vistas à preservação pessoal. FONE, Byrne. Homophobia: a history. Nova York: Picador, 2000, p. 372-406.

${ }^{127}$ Ibid., p. 407.

${ }^{128}$ No Brasil, a coordenação efetiva de grupos em defesa dos direitos dos homossexuais veio a emergir apenas no fim da década de 1970. Muito embora o país tenha vivenciado uma crescente urbanização nos anos 50 e 60, fazendo com que metrópoles como Rio de Janeiro e São Paulo se tornassem polos de atração para os homossexuais, o período ditatorial inaugurado em 1964 sufocou a estruturação de movimentos sociais. Nesse período, contudo, uma subcultura gay se instalava nas principais cidades brasileiras e ícones populares, como Caetano Veloso e Ney Matogrosso, surgiam na mídia, transgredindo os papéis tradicionais de gênero. A crise que se abateu sobre o regime militar a partir de 1974 foi o estopim para a articulação de um movimento com o protagonismo dos homossexuais, inaugurado com a criação do grupo Somos, na cidade de São Paulo, em 1979. A respeito, consultar: GREEN, James N. Mais amor e mais tesão: a construção de um movimento brasileiro de gays, lésbicas e travestis. In: Cadernos Pagu, n. 15, 2000, p. 271-295.

${ }^{129}$ BORRILLO, Daniel. Homofobia: história e crítica de um preconceito. Belo Horizonte: Autêntica Editora, 2010, p. 21.
} 
Embora sujeito a criticas do ponto de vista etimológico ${ }^{130}$, o neologismo deu, enfim, um nome à hostilidade contemporânea contra o homoerotismo, de alcance tanto pessoal quanto cultural:

O termo "homofobia" designa, assim, dois aspectos diferentes da mesma realidade: a dimensão pessoal, de natureza afetiva, que se manifesta pela rejeição dos homossexuais; e a dimensão cultural, de natureza cognitiva, em que o objeto da rejeição não é o homossexual enquanto indivíduo, mas a homossexualidade como fenômeno psicológico e social ${ }^{131}$.

A ampla e rápida disseminação do vocábulo faria com que, expandido seu significado, passasse a representar, em seu uso corrente, toda manifestação arbitrária que oprime, ridiculariza, inferioriza ou alija outrem de sua dignidade, tomando por base identidades sexuais e de gênero presumidas ${ }^{132}$.

A homofobia a ser combatida despontava como consequência do heterossexismo, o sistema vigente de hierarquização das expressões da sexualidade, que situa a heterossexualidade como dado natural e pressuposto, referencial de normalidade e legitimidade, relegando todas as demais (sobretudo, a homossexualidade) a uma posição inferior, desviante ou perversa ${ }^{133}$.

Nessa ordem de ideias, separando os homofóbicos e as vítimas de seu preconceito (o normal e o aberrante), paira apenas o epíteto da homossexualidade um qualificador que é, em si, a própria acusação ${ }^{134}$ :

A homofobia é, principalmente, uma acusação de categoria, porque é primariamente direcionada a atos e ao que eles representam em

130 Decomposta, a palavra homofobia denota, em verdade, medo (phobia) em relação ao semelhante (homo), e não propriamente o receio do homossexual. Além disso, enfatiza um tipo de hostilidade em particular, o medo (fobia), em detrimento de outras tantas manifestações (aversão, ódio, ojeriza, desprezo, violência física/psicológica/simbólica) de reprovação à homossexualidade e ao homossexual (BORRILLO, Daniel. Homofobia: história e crítica de um preconceito. Belo Horizonte: Autêntica Editora, 2010, p. 22). Vale mencionar ainda que, tendo em vista limitar-se o termo à questão homossexual, nos últimos anos, nomenclaturas específicas foram forjadas para fazer referência a formas de opressão assemelhadas, a exemplo da lesbofobia ou da transfobia, que, muito embora sejam usualmente agrupadas sob o epíteto homofobia, possuem particularidades e mecanismos próprios de funcionamento enquanto espécies de preconceito ou ideologias discriminatórias. 131 Ibid., p. 22.

132 RIOS, Roger Raupp; SOUZA, Luiz Gustavo Oliveira de; SPONCHIADO, Tobias. Notícias de Homofobia e Proteção Jurídica Antidiscriminatória. In: DINIZ, Debora; OLIVEIRA, Rosana Medeiros. Notícias de Homofobia no Brasil. Brasília: Letras Livres, 2014. p. 165.

${ }^{133}$ BORRILLO, op. cit., p. 23.

${ }^{134}$ Via de regra, as ofensas direcionadas a membros de grupos vulneráveis estigmatizados tendem a ser construídas mediante a associação de adjetivos pejorativos ao estereótipo da categoria. A homofobia, porém, se destaca nesse quesito por prescindir dos adjetivos, no intuito de desmerecer a vítima do preconceito - imputar-lhe a categoria "homossexual" (ou seus equivalentes jocosos - bicha, veado, etc.) é suficiente. 
fantasia, e apenas secundariamente às pessoas que cometem estes atos, mesmo que este século [século $X X$ ] tenha conferido um novo nome a essas pessoas. Este é o preconceito ideológico que mira o fazer, não o $\operatorname{ser}^{135}$.

Se a capacidade de qualificar outrem como homossexual é o que estigmatiza, fazendo transparecer a relação de poder; fica evidente que o potencial hierarquizante da homofobia, como ferramenta mantenedora de uma ordem heterossexista, muito deve ao controle exercido sobre o conceito material de homossexualidade.

Entretanto, a homossexualidade se revela um marcador estigmatizante bastante frágil, uma vez que jamais foram fixados parâmetros claros para caracterizar o homossexual. O enquadramento nesta categoria, pois, pode ser definido a partir da prática de determinados atos com pessoas do mesmo sexo; pela preferência em termos de objeto do desejo sexual; ou mesmo pela auto-identificação — todos esses critérios sujeitos a questionamentos. A dificuldade em muito deriva do fato de não haver traços físicos que definam os homossexuais. Eles (diferente dos judeus, por exemplo) tampouco constituem um grupo com história, identidade e tradições em comum. Pelo contrário, são geralmente oriundos de famílias heterossexuais e se encontram dispersos por praticamente todos os grupos sociais existentes. Como ressalta Young-Bruehl: "homossexuais não são um grupo, a menos que os transformem em um ou que eles assim se organizem em reposta à discriminação que sofrem; eles não têm uma cultura própria, a não ser que se lhes impinja uma subcultura"136.

Em alguma medida, portanto, os homossexuais são categoria criada pelos próprios homofóbicos. Mas, uma vez transformados em um grupo, passaram a se afirmar politicamente, a se apropriar dos sinais de desprestígio que Ihes eram lançados e a convertê-los em motivo de orgulho para, assumindo publicamente a identidade homossexual, buscar modificar a estrutura social que Ihes conferia um papel subalterno.

A afirmação homossexual acaba por desarticular os mecanismos de evitação pelos quais "as pessoas são cortadas, excluídas de participarem em conversações, comunidades, estruturas sociais; a elas não é permitida qualquer voz sobre como elas

\footnotetext{
${ }^{135}$ YOUNG-BRUEHL, Elisabeth. The anatomy of prejudice. Cambridge: Harvard University Press, 1996, p. 143.

${ }^{136}$ Ibid., p. 142, tradução livre, no original: "Homosexuals are not a group unless they are made to be one or unless they respond to discrimination by organizing; they do not have a culture until they have been made into a subculture".
} 
mesmas são tratadas, não podendo falar ou retrucar" ${ }^{137}$. Pela evitação, se camufla a existência de gays e lésbicas, lançando-os à invisibilidade e à marginalidade. A manifestação coletiva e pública dessas pessoas, no entanto, desarticula esse esquema.

Entre as conquistas do movimento, a superação da abordagem médicopatológica da homossexualidade foi lenta e gradual. Passo importante foi dado com a afirmativa, em 1974, da Associação Americana de Psiquiatria de que, isoladamente, a homossexualidade não constituiria nenhum distúrbio mental. Em 1985, orientação semelhante foi adotada pelo Conselho Federal de Medicina brasileiro. Mas, somente em 1993, a homossexualidade foi suprimida do Catálogo Internacional de Doenças (CID 10/1993), mantido pela Organização Mundial da Saúde - OMS. No Brasil, o Conselho Federal de Psicologia foi além, vedando aos profissionais do ramo, por meio da Resolução 1/1999, o exercício de atividades que induzam à patologização das práticas homoeróticas, a difusão de preconceitos relativos ao tema e de propostas de tratamento ou cura da homossexualidade ${ }^{138}$.

As mudanças que marcaram o final do século XX influenciaram sobremaneira dois aspectos da questão homossexual. De um lado, observou-se um gradativo crescimento na integração (ainda insuficiente) desses indivíduos aos ambientes de trabalho e demais cenários sociais antes predominantemente heterossexuais. De outro lado, a afirmação econômica, social e política que vem sendo conquistada pelos homossexuais tem dissolvido a cristalizada repartição binária da sexualidade, na medida em que a visibilidade desconstrói antigas diferenças imaginárias e se começa a conceber uma maior complexidade nas expressões do desejo. Permite-se falar não mais em homossexualidade, mas em homossexualidades e outras tantas formas de vivência da sexualidade ${ }^{139}$.

No limiar do século $\mathrm{XXI}$, os homossexuais haviam se tornado um grupo de relativa visibilidade no Ocidente e de incisiva autoafirmação. A categoria que denotava ofensa foi apropriada como símbolo de orgulho - o orgulho gay, tão bem captado

${ }^{137}$ SCHULMAN, Sarah. Homofobia familiar: uma experiência em busca de reconhecimento. Trad. Felipe Bruno Martins Fernandes. Bagoas: Revista de Estudos Gays, v. 5, p. 67-78, 2010 , p. 74.

${ }^{138}$ VECCHIATTI, Paulo Roberto lotti. Manual da homoafetividade: da possibilidade jurídica do casamento civil, da união estável e da adoção por casais homoafetivos. São Paulo: Método, 2012, p. 34.

139 YOUNG-BRUEHL, Elisabeth. The anatomy of prejudice. Cambridge: Harvard University Press, 1996, p. 450-451. 
pelo famoso slogan do grupo ativista Queer Nation: "We're here, we're queer, get used to it!" ${ }^{140}$. Nas palavras de Young-Bruehl: "Eles, que são agora um dos grupos mais auto-reflexivos e auto-conscientes, (...) enfrentam um dos grupos menos autoreflexivos e auto-conscientes que existe, os homofóbicos"141.

Esse conjunto de fatores permitiu que se disseminasse uma nova concepção de homossexualidade, como um aspecto neutro da identidade pessoal, nem positivo nem negativo em si, e inapto para justificar tratamentos desiguais perniciosos aos homossexuais. Alguns teóricos e ativistas contemporâneos vêm propondo inclusive o abandono das próprias categorias hetero-homo, tendo por base a ideia já frisada por Foucault ${ }^{142}$ de que seriam apenas construções sociais que, enquanto reproduzidas, seguem reforçando as relações de poder e o sistema heterossexista que as sustenta, bem como uma fixidez contra-factual da sexualidade humana ${ }^{143}$.

Da revolta de Stonewall até os dias de hoje, muito da realidade dos homossexuais foi transformada. A temática dos direitos civis de gays e lésbicas entrou definitivamente em pauta, sendo seguida pelas questões relativas à identidade de gênero. Homossexuais, ao menos no Ocidente, vêm aos poucos galgando seu espaço na arena pública e angariando reconhecimento tanto social como jurídico. As homofobias, inclusive oriundas do próprio Estado, são contestadas com vigor, nos mais diversos foros, a despeito dos momentos de retrocesso, como em decorrência do estigma atrelado às contaminações por HIV, na década de $1980^{144}$.

Os avanços da pauta dos movimentos em defesa dos direitos dos homossexuais, de todo modo, são notáveis, tendo em vista o curto tempo de

\footnotetext{
140 "Estamos aqui, somos bichas, é melhor aceitar!" (tradução livre).

${ }^{141}$ YOUNG-BRUEHL, Elisabeth. The anatomy of prejudice. Cambridge: Harvard University Press, 1996, p. 452, tradução livre, no original: "They, who are now one of the most selfreflective and self-conscious of groups (...) confronto ne of the least self-reflective and selfconscious groups, the homophobes".

142 FOUCAULT, Michel. História da sexualidade I: a vontade de saber. Rio de Janeiro: Edições Graal, 1988, p. 43-44.

${ }^{143}$ RIOS, Roger Raupp; SOUZA, Luiz Gustavo Oliveira de; SPONCHIADO, Tobias. Notícias de Homofobia e Proteção Jurídica Antidiscriminatória. In: DINIZ, Debora; OLIVEIRA, Rosana Medeiros. Notícias de Homofobia no Brasil. Brasília: Letras Livres, 2014. p. 114-126.

${ }^{144}$ A respeito da associação entre o HIV e a população homossexual, consultar: TERTO JR., Veriano. Homossexualidade e saúde: desafios para a terceira década de epidemia de HIVIAIDS. Horizontes antropológicos, Porto Alegre, v. 8, n. 17, p. 147-158, Jun. 2002. A temática é abordada também no filme The Normal Heart, que retrata o período de rápida escalada da epidemia de HIV-AIDS, em Nova York, no início da década de 1980 (THE NORMAL HEART. Direção: Ryan Murphy. Produção: Scott Ferguson. Intérpretes: Mark Ruffalo; Matt Bomer; Taylor Kitsch; Jim Parsons; Julia Roberts. Roteiro: Larry Kramer. Estados Unidos: HBO, 2014, 132min).
} 
existência de organizações engajadas nessas causas. Segundo dados da Associação Internacional de Lésbicas, Gays, Bissexuais, Trans e Intersex (International Lesbian, Gay, Bisexual, Trans and Intersex Association - ILGA), em meados de 2015, a prática de atos sexuais homoeróticos já era legalizada em 118 países ao redor do globo - aproximadamente $61 \%$ dos membros da Organização das Nações Unidas. Em 17 países, em sua maioria europeus, é assegurado o direito ao casamento entre pessoas do mesmo sexo, enquanto que em pelo menos outros 17 esses relacionamentos gozam de algum nível reconhecimento jurídico ${ }^{145}$.

Parte dessas conquistas não decorreu de efetiva mudança legislativa promovida pelos parlamentos nacionais, mas da intervenção promovida pelo Poder Judiciário. Foi o que se passou no Brasil, com o reconhecimento, aos casais homoafetivos, dos direitos decorrentes do regime de união estável, levado a cabo pelo Supremo Tribunal Federal, em maio de $2011^{146}$. Precedentes de outras cortes que vieram em seguida, ${ }^{147}$ autorizando também o casamento civil, resultaram na disciplina da questão pelo Conselho Nacional de Justiça (Resolução 175/2013), estendendo esse direito a todo o território brasileiro. Mais recentemente, a questão do casamento entre pessoas do mesmo sexo voltou à tona, quando a Suprema Corte dos Estados Unidos, no emblemático caso Obergefell v. Hodges ${ }^{148}$, declarou que este seria um direito decorrente da Décima Quarta Emenda à Constituição norte-americana, unificando, desse modo, o tratamento até então fragmentado que se dava à matéria.

Não obstante as vitórias alcançadas, a homofobia persiste entranhada na cultura e em grande parte dos ordenamentos jurídicos ocidentais, dando vazão à discriminação indireta e direta - muito frequentemente traduzida em violência física. Alcançou-se um patamar de relativa tolerância em alguns países, mas ainda não se pode falar em definitiva aceitação ou reconhecimento das pessoas homossexuais.

A prevalência de uma mentalidade calcada no heterossexismo, não permite a muitos vislumbrar discriminação na dispensa de trato diferenciado e deletério a outrem

\footnotetext{
${ }^{145}$ ILGA. State-sponsored homophobia. Word survey of laws: criminalization, protection and recognition of same-sex love. VALENZA, Alessia; CAROLL, Aengus (Coord.). 10. ed., mai/2015.

${ }^{146}$ BRASIL. Supremo Tribunal Federal. ADPF 132, Relator Min. AYRES BRITTO, Tribunal Pleno, julgado em 05/05/2011, DJe de 14/10/2011.

${ }^{147}$ Nesse sentido, consultar: BRASIL. Superior Tribunal de Justiça. REsp 1183378/RS, Rel. Ministro LUIS FELIPE SALOMÃO, QUARTA TURMA, julgado em 25/10/2011, DJe 01/02/2012.

${ }^{148}$ Obergefell v. Hodges, 14-556 (2015).
} 
por conta da homossexualidade. A disseminação de discursos heteronormativos ou mesmo de viés escancaradamente homofóbico frequentemente se faz de maneira inconsciente e, quando assinalada, ainda não estimula repulsa e indignação tão intensos quanto preconceitos firmados em outras bases, a exemplo do racismo. Sob a percepção de que apenas se estaria tratando distintamente o desigual na medida de suas diferenças, jaz a ignorância quanto ao fato de que essas diferenças tão evidentes e inconciliáveis são construções naturalizadas e bastante recentes.

Nessa esteira, atos homossexuais permanecem no rol de ilícitos de 75 países - 39\% dos integrantes da ONU. Alguns países, como a Federação Russa, embora não criminalizem a homossexualidade, contam com severas restrições legais ao que denominam "propaganda gay", instituindo verdadeira censura à abordagem do tema e à articulação de organizações em defesa dos direitos da população LGBT ${ }^{149}$. Pouco mais de 60 países, excluído o Brasil, contam com diplomas normativos que vedam a discriminação homofóbica no âmbito empregatício. Apenas 8 têm expressamente inscrita, em suas respectivas Constituições, a proibição geral à discriminação motivada por orientação sexual. Os crimes de ódio contra homossexuais são reconhecidos por 35 países, sendo ainda menor (31) o número dos que proíbe a incitação ao ódio com base na orientação sexual - o Brasil não dispõe de nenhuma dessas garantias ${ }^{150}$.

Em verdade, embora a prática de atos sexuais consentidos entre pessoas do mesmo sexo seja lícita no Brasil e o Judiciário venha reconhecendo direitos a casais homoafetivos, o déficit de proteção legal contra a discriminação homofóbica é sintomática de um quadro social de forte preconceito heterossexista ainda insculpido, em grande medida, na mentalidade do povo brasileiro. Direitos conquistados na seara judicial nem sequer contam com o respaldo da população: segundo levantamento do IBOPE Inteligência, conduzido em 2011, 55\% dos brasileiros posicionam-se contrariamente à aprovação da união estável para homossexuais ${ }^{151}$. Noutro giro, à míngua de uma preocupação governamental nesse sentido, a ONG Grupo Gay da Bahia - GGB contabilizou, por anos, as vítimas da violência homofóbica no país,

\footnotetext{
${ }^{149}$ Lésbicas, Gays, Bissexuais, Travestis e Transexuais.

150 ILGA. State-sponsored homophobia. Word survey of laws: criminalization, protection and recognition of same-sex love. VALENZA, Alessia; CAROLL, Aengus (Coord.). 10. ed., mai/2015.

151 IBOPE Inteligência. União estável entre homossexuais. Disponível em: <http://www4.ibope.com.br/download/casamentogay.pdf>. Acesso em 10/02/2016.
} 
registrando um número crescente de homicídios relacionados ao preconceito antihomossexual $^{152}$. Apenas em 2012, foi divulgada a primeira apuração oficial, compilada pela Secretaria de Direitos Humanos da Presidência da República no Relatório sobre Violência Homofóbica no Brasil. Em sua segunda edição, a SDH registrou um aumento de $166,09 \%$ na quantidade de denúncias de violações relacionadas à população LGBT, entre 2011 e 2012 (1.159 contra 3.084). As ocorrências, em âmbito público e privado, compreendem um vasto leque de hostilidades: de violências psicológicas, como a chantagem, a humilhação e a ameaça; a homicídios, lesões corporais e violações sexuais ${ }^{153}$.

As homofobias e a ideologia heterossexista permanecem inscritos na estrutura social, espraiando-se pelos diferentes cenários do cotidiano e reclamando, para cada um, análises e intervenções específicas, que fomentem a desconstrução de estruturas de dominação, dando lugar ao reconhecimento e à efetiva integração social. Como se destacará nos capítulos seguintes, o mundo do trabalho, com todas as peculiaridades do atual modelo produtivo hegemônico, não escapa às influências desse sistema que organiza a existência humana hierarquicamente a partir de identidades sexuais preconcebidas. O cruzamento das relações de sexo com as relações econômicas, aliás, faz com que essas formas de dominação alimentem uma à outra. Passando, por vezes, despercebida na dinâmica do trabalho, a homofobia nesses contextos merece, tanto quanto em outros, ser objeto de estudo particularizado que a destaque e a deslegitime onde permanece invisível, frisando as repercussões inclusive jurídicas que pode engendrar.

Ao fim e ao cabo, como elucida Byrne Fone, "enquanto for legitimada pela sociedade, pela religião e pela política, a homofobia vai dar ensejo ao ódio, ao desprezo e à violência, e continuará sendo nosso último preconceito aceitável” ${ }^{154}$.

\footnotetext{
${ }^{152}$ Em 2014, a organização catalogou 326 homicídios no país, possivelmente relacionados a motivações homofóbicas. GGB. Assassinato de homossexuais (LGBT) no Brasil: relatório 2014. Disponível em: <https://homofobiamata.files.wordpress.com/2015/01/relatc3b3rio2014s.pdf>. Acesso em 10/02/2016.

${ }^{153}$ BRASIL. Secretaria de Direitos Humanos. Relatório sobre violência homofóbica no Brasil: ano de 2012. 2013. Disponível em: <http://www.sdh.gov.br/assuntos/lgbt/pdf/relatorioviolencia-homofobica-ano-2012>. Acesso em 10/02/2016.

${ }^{154}$ FONE, Byrne. Homophobia: a history. Nova York: Picador, 2000, p. 421, tradução livre, no original: "So long as it is legitimated by society, religion, and politics, homphobia will spawn hatred, contempt, and violence, and it will remain our last accpetable prejudice".
} 


\section{HETEROSSEXISMO E HOMOFOBIAS EM TEMPOS DE TRABALHO FLEXÍVEL}

\subsection{0 discurso neoliberal e o modelo toyotista de produção}

Nos anos subsequentes ao desfecho da Segunda Guerra Mundial, em 1945, o modelo de Estado de Bem-Estar Social (Welfare State) foi encampado como solução ideal para viabilizar a sobrevivência de boa parte dos fragilizados países da Europa Ocidental. A premissa era a de que um Estado fortalecido seria capaz de resguardar os direitos da população e, intervindo para corrigir desequilíbrios, poderia recuperar a atividade econômica $^{155}$.

Sob essa ótica, o Estado arrogou para si as funções de planejamento, assistência social, prestação de serviços públicos e organização da economia. No período, implementou-se a política de pleno emprego, expandiu-se o rol de direitos de segunda dimensão e, aos de primeira, conferiu-se um enfoque social. No mesmo passo, o Direito do Trabalho fincou raízes, consolidando a sua assimilação pelos ordenamentos jurídicos como um ramo autônomo e consistente ${ }^{156}$.

A indústria adotou o modelo fordista de produção como paradigma, atrelado às anteriores proposições advindas do taylorismo. Concebido por Henry Ford, originalmente para o setor automobilístico, o fordismo tem como um de seus pilares a estrutura empresarial verticalizada, para fazer frente à produção em massa, ocupando-se do ciclo produtivo em sua integralidade — da obtenção de insumos à finalização do produto. Esse modelo prima pela racionalização da produção, reduzindo tempos ociosos e ampliando o ritmo de trabalho, principalmente pela especialização do obreiro, que, inserto na linha de montagem, se ocupa repetida e mecanicamente de uma etapa específica do processo produtivo, distanciando pensar e $\operatorname{agir}^{157}$.

Nesse quadro, a existência de um aparato normativo assistencialista, em grande medida apoiado pelos sindicatos, e o estabelecimento de relações de trabalho dotadas de estabilidade desestimulavam contestações obreiras significativas ao próprio modelo em vigor. Nessa esteira, a grande e pesada empresa fordista sustentou uma produção em massa de bens homogêneos, com progressiva expansão

${ }^{155}$ DELGADO, Gabriela Neves. Direito fundamental ao trabalho digno. 2. ed. São Paulo: LTr, 2015, p. 143.

${ }^{156}$ Ibid., p. 144.

157 Ibid., p. 145-146. 
da acumulação capitalista, até o início da década de 1970, quando, em meio a uma de suas crises estruturais, o esgotamento desse modelo foi se tornando evidente ${ }^{158}$.

O rompimento com a fase áurea do capitalismo, no século $\mathrm{XX}$, foi catalisado pela justaposição de fatores, como o progressivo inchaço da esfera financeira em detrimento do capital produtivo; a formação de monopólios, por meio da fusão e da incorporação de organizações empresariais; o encarecimento da força de trabalho e um consequente decréscimo nas taxas de lucro das empresas; o aparecimento de excessos de produção incompatíveis com a contração do consumo e o quadro de desemprego estrutural que se esboçava; e o colapso do modelo de Welfare State, que, num contexto de desequilíbrio fiscal e estagnação, tornou inadiável o enxugamento dos gastos públicos, com a transferência de atividades e custos para o setor privado ${ }^{159}$.

Em outra frente, a renovação tecnológica que despontava, encabeçada pela robótica, pela microeletrônica e pela microinformática, propiciou transformações em setores econômicos variados. Em alguns casos, deu ensejo à redução de postos de trabalho, ocasionada pela substituição do trabalho humano pelo maquinário; e, em outros, à modificação das formas de prestação de serviço, com o surgimento de novas modalidades laborativas, estranhas à relação empregatícia clássica ${ }^{160}$.

Diante desse quadro, o capitalismo precisava se reinventar. Iniciou-se, então, um processo de reorganização do sistema político e ideológico hegemônico, voltado ao resgate dos valores da livre negociação e do absenteísmo estatal. No âmago do neoliberalismo, figuram agora, como prioridades, "a privatização do Estado, a desregulamentação dos direitos do trabalho e a desmontagem do setor produtivo estatal”161, com vistas à otimização da produção, à retomada do crescimento econômico e à expansão das taxas de lucro.

Esse movimento foi acentuado por vitórias políticas estratégicas, em países de capitalismo avançado, notadamente a ascensão de Margaret Thatcher como

\footnotetext{
${ }^{158}$ DELGADO, Gabriela Neves. Direito fundamental ao trabalho digno. 2. ed. São Paulo: LTr, 2015, p. 147-148.

${ }^{159}$ ANTUNES, Ricardo. Os sentidos do trabalho: ensaios sobre a afirmação e a negação do trabalho. São Paulo: Bomtempo, 2003, p. 29-30.

160 DELGADO, Maurício Godinho. Curso de direito do trabalho. 11. ed. São Paulo: LTr, 2012, p. 98-99.

${ }^{161}$ ANTUNES, op. cit., p. 31.
} 
primeira-ministra do Reino Unido, em 1979, e a eleição do presidente dos Estados Unidos, Ronald Reagan, em $1980^{162}$.

Da reestruturação de um combalido Estado Social, o neoliberalismo expandiuse como ideário condutor de um Estado Poiético, ${ }^{163}$ em que o político e o jurídico se subordinam ao imperativo econômico. Nas palavras de Joaquim Salgado:

No Estado poiético, o produto do fazer é o econômico, que nenhum compromisso tem com o ético, e procura, com a aparência de cientificidade, subjugar o político, o jurídico e o social. Não é ético, porque o seu fazer não se dirige a realizar os direitos sociais. Evidentemente, se o Estado realiza os direitos sociais, esse fazer é ético ${ }^{164}$.

Desregulamentação e flexibilização exsurgem como as propostas neoliberais para uma nova abordagem das relações de trabalho e de emprego: a primeira (desregulamentação), ancorada na ideia de mínima intervenção, "exige que o Estado deixe de regular questões sociais inclusive as de cunho trabalhista, em prol da regulação autônoma privada, individual ou coletiva"; e a segunda (flexibilização) designa o movimento de "atenuação do suposto rigor e imperatividade das normas jurídicas, mediante negociações coletivas" ${ }^{165}$.

No projeto político do Estado Poiético, de progressivo desmonte do sistema protetivo, o trabalho se encontra sob "fogo cruzado"166 e a lógica do mercado se inscreve nas relações laborais, sobretudo na categoria do emprego, desalojando-as do seu potencial como mecanismo de integração social e de construção da identidade. O trabalho é desconfigurado enquanto espaço de realização e promoção da dignidade

\footnotetext{
162 DELGADO, Gabriela Neves. Direito fundamental ao trabalho digno. 2. ed. São Paulo: LTr, 2015, p. 149.

${ }^{163}$ Conforme Salgado, o Estado Poiético se configura como a "ruptura no Estado Ético contemporâneo que alcançou a forma do Estado de Direito". SALGADO, Joaquim Carlos. Estado ético e estado poiético. Revista do Tribunal de Contas do Estado de Minas Gerais, Belo Horizonte, v. 27, n. 2, abre./jun., 1998. Disponível em: <http://200.198.41.151:8081/tribunal_contas/1998/02/-sumario?next=3>. Acesso em: $11 / 02 / 2016$.

164 Ibid.

165 DELGADO, op. cit., p. 172-173.

166 Segundo Porchmann, o neoliberalismo propaga a ideia de que o cenário de crise seria decorrência direta de um descontrolado e desmesurado intervencionismo estatal no âmbito econômico, nas décadas anteriores aos anos 1970 - razão pela qual um mercado desimpedido seria a única solução viável para que a geração de empregos fosse retomada. O que se oculta, com esse discurso, porém, é que não apenas o desemprego segue crônico, com o avanço do neoliberalismo, mas o mercado desregulado tende a criar ocupações marcadamente precárias e instáveis, distantes de um ideal de trabalho que propicie verdadeira integração social. Cf. PORCHMANN, Marcio. O trabalho sob fogo cruzado: exclusão, desemprego e precarização no final do século. São Paulo: Contexto, 1999.
} 
humana, quando o próprio trabalhador, sob a óptica econômica, é objetificado, passando a ser visto como instrumento do sistema produtivo ${ }^{167}$.

As mudanças no âmbito estatal seriam acompanhadas por uma correlata transformação do sistema produtivo. Afinal, como sustenta Delgado, "Para cada tipo de necessidade do capital, estabelecia-se um modelo de produção específico, sob a conjuntura de determinado paradigma de Estado" ${ }^{168}$.

Com efeito, a reestruturação do capitalismo, no intuito de contornar o esgotamento do taylorismo-fordismo e de recuperar os níveis de acumulação anteriores à deflagração da crise dos anos 1970, sem abalar ou modificar substancialmente o próprio sistema capitalista, conferiu especial destaque à implementação de mudanças nos modelos de produção e nas formas de gestão do trabalho.

Assim como o Estado, as empresas também passaram a privilegiar estruturas menores, mais eficientes, com vistas à maximização de lucros. Com essa proposta, surge, então, e se dissemina o modelo toyotista de produção, cujas proposições iam de encontro às grandes estruturas que caracterizaram o fordismo/taylorismo.

O toyotismo, enquanto "ideologia orgânica do novo complexo de reestruturação produtiva do capital” ${ }^{169}$, com alcance global, se espelha no modelo de gestão concebido por Taiichi Ohno, no Japão, entre o final dos anos 1970 e início dos anos 1980. Ancora-se, em síntese, no tripé da produção enxuta (lean produtcion), com um achatamento da estrutura organizacional (downsizing), eliminando excessos, a fim de permitir o pronto atendimento (just-in-time), com qualidade total ${ }^{170}$. Objetiva-se, desse modo, alcançar um diferencial competitivo para a empresa, ampliando as margens de lucro do empreendimento e reduzindo os seus custos.

Entre as técnicas e medidas introduzidas por esse novo modelo, sobressai, de um lado, a substituição da produção em massa por um processo produtivo restrito, de poucas unidades, voltadas ao atendimento de demandas localizadas e especializadas - o que permite a eliminação dos grandes estoques. De outro lado, destaca-se o abandono da estrutura vertical, na qual a empresa se ocupava de todas

\footnotetext{
${ }^{167}$ DELGADO, Gabriela Neves. Direito fundamental ao trabalho digno. 2. ed. São Paulo: LTr, 2015, p. 21.

168 Ibid., 160.

${ }^{169}$ ALVES, Giovanni. Trabalho e subjetividade: o espírito do toyotismo na era do capitalismo manipulatório. São Paulo: Bomtempo, 2011, p. 43.

${ }^{170}$ DELGADO, op. cit., p. 161.
} 
as etapas da cadeia produtiva, em prol de uma produção horizontalizada ${ }^{171}$, focada no núcleo de sua atividade, externalizando as demais etapas e áreas consideradas periféricas para pequenas e médias empresas ${ }^{172}$.

No tocante ao trabalho, a empresa toyotista torna premente a adoção de formas de prestação de serviços mais flexíveis do que a clássica relação de emprego. A fluidez da demanda e da produção, afinal, exigiria uma correspondente maleabilidade das condições de contratação e de dispensa, bem como de remuneração dos obreiros.

Nesse contexto, Harvey vislumbra dois grandes grupos de trabalhadores inseridos no contexto organizacional: um grupo pequeno e central de obreiros, com alto grau de qualificação, os quais, trabalhando em tempo integral, gozam de maior estabilidade e perspectivas de crescimento; e um grupo periférico, constituído pela grande massa de trabalhadores, de baixa qualificação, sujeitos a regimes mais precários de contratação (como o contrato por tempo parcial ou o trabalho temporário), à menor segurança no emprego e à alta rotatividade ${ }^{173}$.

De outro ângulo, a partir da introdução do conceito de ilha de produção, a tradicional linha de montagem, com obreiros especializados e incumbidos de etapas segmentadas do processo produtivo, cede lugar a um necessário trabalho em equipes integradas por trabalhadores polivalentes. Sujeitos à constante ameaça da perda do emprego e à demanda por aptidão para o exercício de múltiplas competências, os trabalhadores tornam-se interdependentes e forçados a agir em conjunto. De outra parte, a comparação de desempenho entre as equipes acentua a competição e o individualismo, fazendo com que os próprios obreiros passem a controlar a atuação uns dos outros ${ }^{174}$, de modo a garantir que sejam atendidas e até mesmo excedidas as metas designadas para o grupo. Cada trabalhador torna-se responsável não

171 A produção horizontalida tem como uma de suas técnicas mais emblemáticas a terceirização, isto é a triangulação da relação de trabalho, em que o obreiro, embora inserido no processo produtivo da empresa tomadora de serviços (contratante), tem seu vínculo justrabalhista firmado com um intermediário, a empresa prestadora de serviços (contratada). DELGADO, Maurício Godinho. Curso de direito do trabalho. 13. ed. São Paulo: LTr, 2014, p. 452.

172 DELGADO, Gabriela Neves. Direito fundamental ao trabalho digno. 2. ed. São Paulo: LTr, 2015, p. 161-162.

${ }^{173}$ HARVEY, David. A condição pós-moderna. São Paulo: Loyola, 1989, p. 144.

174 Também nesse quesito, tem-se um enxugamento de gastos, tornando desnecessária a alocação de trabalhadores responsáveis exclusivamente por fiscalizar a realização de tarefas. Os próprios membros da equipe são estimulados a desempenhar esse papel, em adição as atividades que já Ihes cabem, permitindo, assim, um achatamento das hierarquias. 
apenas pelo seu próprio sucesso, mas pelo eventual fracasso dos demais obreiros e do próprio empreendimento ${ }^{175}$.

De forma menos visível, mas igualmente impactante, o modelo toyotista se propõe a moldar os valores e a subjetividade do trabalhador, fazendo-o aderir aos princípios, à visão e ao projeto da organização empresarial na qual está inserido. Se estimula o trabalhador a criar uma identificação com a própria empresa, essa estratégia estremece, porém, o desenvolvimento de uma identidade coletiva obreira e a representatividade dos sindicatos ${ }^{176}$.

As sutis mudanças ocorrem inclusive no nível do discurso: o empregado passa a ser denominado "colaborador", disseminando-se a ideia de uma administração compartilhada do empreendimento e camuflando-se o conflito entre capital e trabalho ${ }^{177}$ — tudo com vistas a se obter a participação proativa do trabalhador (ou o "engajamento estimulado do trabalho", conforme Giovanni Alves ${ }^{178}$ ), mormente dos integrantes do restrito eixo de trabalhadores centrais altamente qualificados.

Somente com este engajamento aparentemente espontâneo, a organização toyotista pode dispor de uma força de trabalho capaz de se adaptar às variações e às especificidades da demanda que regem o modelo de produção flexível.

Ao fim e ao cabo, o trabalhador contemporâneo sujeita corpo e mente à organização empresarial, impactando sua existência social para além do contexto profissional. Cuida-se, nas palavras de Giovanni Alves, da "captura" da subjetividade do trabalhador, isto é, "a constituição de um novo nexo psicofísico capaz de moldar e direcionar ação e pensamento de operários e empregados em conformidade com a racionalização da produção"179.

\subsubsection{O trabalho flexível na modernidade líquida}

${ }^{175}$ DELGADO, Gabriela Neves. Direito fundamental ao trabalho digno. 2. ed. São Paulo: LTr, 2015, 162-163.

176 Ibid., 163.

177 BERNARDO, Marcia Espanhol. Trabalho duro, discurso flexível: uma análise das contradições do toyotismo a partir da vivência dos trabalhadores. São Paulo: Editora Expressão, 2009, p. 65.

${ }^{178}$ ALVES, Giovanni. Trabalho e subjetividade: o espírito do toyotismo na era do capitalismo manipulatório. São Paulo: Bomtempo, 2011, p. 49.

179 Ibid., p.111. 
Zygmunt Bauman é autor da expressão modernidade líquida, como forma de designar o período mais recente da contemporaneidade. Segundo o sociólogo, a atribuição da liquidez a um conceito histórico se revela apropriada, na medida em que a mobilidade, a flexibilidade e a aptidão para sobrepor barreiras e dissolver o previamente estabelecido, típicas dos líquidos, são traços característicos da mentalidade hodierna ${ }^{180}$.

Com efeito, a história recente destoa da solidez que tão bem ilustrava o final do século XIX e boa parte do século $X X$, em que as noções de controle rígido, regulação e ordem governavam a existência. Tudo continha um propósito a ser efetivado e a estabilidade do sistema assegurava que a humanidade seguiria em direção ao progresso ${ }^{181}$.

A fábrica fordista, para Bauman, era o melhor exemplo do ideal da primeira modernidade: mirava a grandeza e a suposta perenidade dos empreendimentos, fixados em determinados territórios, num quadro de interdependência entre capital e trabalho, em relações de longo prazo. Essa regularidade (e aparente estabilidade) era o que alimentava a manutenção do sistema produtivo, com vistas a um constante crescimento $^{182}$.

O trabalho era um valor essencial na corrida pelo progresso da modernidade sólida, elemento indispensável para a manutenção das pesadas organizações que guiavam a humanidade para a frente. O vínculo se pretendia de tal forme forte e as perspectivas, a longo prazo, que o obreiro contava com boas chances de trilhar uma vida inteira dentro do quadro de funcionários de uma mesma empresa.

Conforme Enriquez, essa modernidade sólida engendrava uma nova concepção sobre o trabalho, rompendo com a percepção negativa da antiguidade:

A nova mentalidade sobre o trabalho vai gerar o que chamamos de mobilização geral dos seres humanos para o trabalho. Vemos aí se desenvolver a idéia de que os indivíduos que não trabalham são parasitas, delinqüentes e inúteis. Ou que, em certo sentido, aqueles que não trabalham não têm o direito de comer. Com se vê, trata-se realmente de uma civilização do trabalho e dos trabalhadores. Ou seja, com o desenvolvimento dessa idéia de trabalho e o aparecimento posterior da grande empresa, vamos constatar que não apenas os grandes empreendedores e empresário estão interessados no trabalho, mas ao mesmo tempo e progressivamente, também os operários. Estes, mesmo que freqüentemente alienados e explorados,

\footnotetext{
${ }^{180}$ BAUMAN, Zygmunt. Modernidade líquida. Rio de Janeiro: Zahar, 2001, p. 67-70

181 Ibid., p. 9-14.

182 Ibid., p. 67.
} 
vão justamente reivindicar o trabalho como um elemento constitutivo e fundamental da sua personalidade ${ }^{183}$.

Mormente nos anos seguintes à Segunda Guerra, o trabalho assumiu a condição de elemento integrador da sociedade, que constitui e reforça laços sociais. O trabalhador era uma figura central para um capitalismo que, ao lado do reconhecimento de direitos sociais e da estruturação de um Estado Providência, parecia se humanizar no curso de seu desenvolvimento. Essa tendência se interrompe e se inverte, nas últimas três décadas do século $X X^{184}$.

A crise das estruturas da modernidade sólida tornou evidente que o projeto moderno original jamais alcançaria um ponto final. Quando o longo prazo cede espaço ao imediatismo, o quadro de aparente estabilidade e entrelaçamento rígido do trabalho com o capital se desorganizou.

Se, de um lado, o ciclo de destruição criativa que alimentava o capitalismo se encarregou de erigir continuamente novas metas e objetos de desejo; de outro, tecnologia e revoluções no campo da comunicação encurtaram distâncias e facilitaram o agir, tornando desnecessária e custosa a manutenção da grandeza, quando o desfrute de benefícios equivalentes a partir de estruturas menores e em tempo mais curto se tornou possível.

A parceria cuja previsão era inicialmente por tempo indeterminado, em face das recentes inseguranças e riscos que despontavam, deveria se adequar a períodos certos e mais estreitos ${ }^{185}$.

O capital, aderindo à leveza e à mobilidade, afrouxa seus laços de engajamento com o trabalho, que passa a assumir importância secundária no contexto da acumulação. Desembaraçado e, principalmente, desvinculado de territórios, o capital financeirizado ganham em poder de barganha, pois, diante de qualquer empecilho a seus objetivos, pode se deslocar e se estabelecer em outro local mais afinado com seus interesses, com a mesma precariedade e prontidão para a fuga com que procedera no anterior. Os Estados, na tentativa de atrair o interesse dessas potências voláteis, acabam cedendo à exigência do neoliberalismo pela eliminação de barreiras ao desenvolvimento da atividade econômica ${ }^{186}$. Em termos do trabalho, isso

\footnotetext{
${ }^{183}$ ENRIQUEZ, Eugène. Perda do trabalho, perda da identidade. Cad. Esc. Leg., Belo Horizonte, 5(9), jul./dez. 1999, p. 57.

184 Ibid., p. 58.

185 BAUMAN, Zygmunt. Modernidade líquida. Rio de Janeiro: Zahar, 2001, p. 166-169.

${ }^{186}$ Ibid., p. 171-172.
} 
implica o desmonte de sistema jurídico protetivo rígido, com a retirada da intervenção estatal em favor da negociação meramente privada.

Num ambiente em que o poder está nas mãos daqueles dotados da capacidade de se mover sem contratempos, sem precisar carregar muito peso, 0 grande valor não se encontra mais em objetos materiais, mas em ideias. O foco passa à relação com os consumidores, relegando produtores e trabalhadores ao segundo plano. Nesse novo cenário, somente despertar o interesse e o efêmero desejo das massas consumidoras pelas ideias à venda pode significar chances substanciais de lucro e de destaque diante da concorrência ${ }^{187}$.

O recrudescimento da guerra econômica, com a elevação da competitividade (entre empreendimentos e entre trabalhadores) ao patamar dos valores socialmente caros, importa a disseminação de uma visão racional da vida, de viés marcadamente econômico e instrumental, em detrimento do estreitamento dos laços humanos e da preocupação com o sofrimento alheio ${ }^{188}$.

Para o capitalismo volátil do século $\mathrm{XXI}$, o trabalho não é uma questão central como outrora. Sob o pensamento financeiro, as empresas se inclinam a encarar como objetos plenamente substituíveis os seres humanos que lhes prestam serviços, ao sabor do humor dos mercados, que alocam e desalocam recursos e investimentos com uma facilidade sem precedentes ${ }^{189}$.

Nessas circunstâncias, o enxugamento dos quadros de empregados das empresas não é mais um indicativo de problemas. Pelo contrário, as ondas de dispensas e a redistribuição de funções, visando à maior eficiência e a melhores resultados, tornam-se práticas recorrentes, mesmo quando o negócio vai bem. No modelo flexível, nem mesmo aqueles que ocupam posições mais elevadas na hierarquia empresarial estão à salvo de eventuais cortes ${ }^{190}$.

$\mathrm{Na}$ relação trabalhista flexível, não se pode esperar que as partes que a integram formem laços firmes ou compromissos de longo prazo. Nesse passo, a recente ausência de segurança no trabalho acaba por intensificar a responsabilidade de cada obreiro por garantir a própria sobrevivência, acentuando, por conseguinte, o processo de individualização e de inibição da ação coletiva.

\footnotetext{
${ }^{187}$ BAUMAN, Zygmunt. Modernidade líquida. Rio de Janeiro: Zahar, 2001, p. 173-174.

188 ENRIQUEZ, Eugène. Perda do trabalho, perda da identidade. Cad. Esc. Leg., Belo Horizonte, 5(9), jul./dez. 1999, p. 60-61.

189 Ibid., p. 64.

${ }^{190}$ Ibid., p. 65.
} 


\subsubsection{O sofrimento nas organizações maleáveis}

De acordo com Cristophe Dejours, trabalhar ${ }^{191}$ corresponde a "um certo modo de engajamento da personalidade para responder a uma tarefa delimitada por pressões (materiais e sociais)" ${ }^{\prime 192}$.

Nesses termos, o trabalho é tanto atividade quanto forma de relação social, uma experiência individual e coletiva. De um lado, se desenvolve a partir da mobilização da subjetividade para suprir a defasagem das prescrições que orientam o trabalhar perante as contingências e a complexidade que a realidade apresenta. De outro, envolve o engajar-se em "um mundo humano caracterizado por relações de desigualdade, de poder e de dominação"193.

Para Dejours, enquanto desdobramento da inevitável experiência subjetiva perante resistências materiais e sociais ${ }^{194}$, o sofrimento é, portanto, ínsito ao trabalho. Trabalhar pressupõe uma relação afetiva do sujeito com as inconsistências, imprevistos, acidentes, falhas e conflitos que o real comporta. Esse sofrimento é, contudo, passível de ressignificação, convolando em prazer, gratificação e alívio. A pedra de toque dessa transição repousa na existência de condições para que, no âmbito laboral, se desenvolva uma dinâmica de "reconhecimento, pelo outro, da

191 O conceito de trabalho sobre o qual disserta Dejours, como sendo o próprio trabalhar, ancora-se na perspectiva clínica da psicodinâmica do trabalho.

192 DEJOURS, Cristophe. Subjetividade, trabalho e ação. Revista produção, v.14, n. 3, p. $27-$ 34 , set./dez. 2004, p. 28.

${ }^{193}$ Ibid., p. 31.

${ }^{194}$ Nas palavras de Cristophe Dejours, "o real do trabalho é definido como o que resiste ao conhecimento, ao saber, ao savoir-faire e, de modo mais geral, ao domínio" (Id., A banalização da injustiça social. 7. ed. Rio de Janeiro: Editora FGV, 2007, p. 29). Essa resistência (da matéria e dos objetos técnicos ao domínio, ou dos conflitos inerentes às relações sociais travadas em um mundo desigual) há de ser superada sob uma dupla perspectiva, para que o trabalhar seja efetivo e os objetivos da atividade, alcançados. No plano individual, a angústia e a frustração decorrentes da defasagem da organização prescrita (procedimentos, normas e instruções que orientam o desempenho das tarefas) ante os imprevistos da realidade, precisam servir de gatilho para a mobilização da inteligência individual, com vistas à experimentação e à busca de soluções para os problemas concretos do trabalhar. Em contrapartida, no plano coletivo, faz-se necessária a articulação das inteligências individuais, de modo a evitar contradições e conflitos no funcionamento do todo. Isso se opera, em parte, pela a coordenação formal dessas inteligências (prescrições que ordenam a divisão social e técnica do trabalho, com repartição de atribuições e de prerrogativas), sendo complementada pelo desenvolvimento de uma cooperação efetiva dos trabalhadores (o estabelecimento de compromissos, técnicos e sociais, "entre os estilos de trabalho, entre as preferências de cada trabalhador, de forma a torná-los compatíveis") (Id., op. cit., 2004, p. 28-31). 
contribuição do sujeito para a administração da defasagem entre a organização prescrita e a organização real do trabalho"195.

Em perspectiva, essa retribuição simbólica, que atende aos anseios narcisísticos de todo obreiro, nutre o sentimento de utilidade, de pertencimento ao coletivo, e faz com que as angústias e as dificuldades experimentadas no trabalhar não sejam em vão. É no reconhecimento da qualidade e da importância do seu trabalho que se sustenta a motivação do sujeito para continuar mobilizando sua inteligência e sua personalidade no trabalho ${ }^{196}$. Dele também depende o desenvolvimento de relações de cooperação efetiva entre os obreiros, para juntos articularem suas inteligências individuais em prol dos objetivos do empreendimento ${ }^{197}$.

Por meio da inserção do obreiro na realidade organizacional, o trabalho, nesse sentido, promove a integração em sociedade (possibilidade de viver junto, tendo prazer nesse convívio), a sedimentação das personalidades e instauração da temporalidade. Ele torna possível, ao sujeito, conferir um sentido à própria vida ${ }^{198}$.

Sem embargo, a concretização desse potencial do trabalho para constituir um espaço social de reconhecimento e de integração se limita pela conformação das atividades produtivas e da gestão do trabalho predominantes em um dado cenário histórico $^{199}$.

Como já se pontuou, todavia, se há algo que caracterize a postura neoliberal hodierna perante o trabalho é a sua inclinação para, sob uma lógica instrumental, esgarçar paulatinamente as condições que sustentam uma dinâmica de reconhecimento e cooperação ${ }^{200}$.

195 DEJOURS, Cristophe. A banalização da injustiça social. 7. ed. Rio de Janeiro: Editora FGV, 2007, p. 97.

${ }^{196}$ Ibid., p. 34

${ }^{197}$ Id., Subjetividade, trabalho e ação. Revista produção, v.14, n. 3, p. 27-34, set./dez. 2004, p. 33.

${ }^{198}$ ENRIQUEZ, Eugène. Perda do trabalho, perda da identidade. Cad. Esc. Leg., Belo Horizonte, 5(9), jul./dez. 1999, p. 67-68.

${ }^{199}$ HELOANI, José Roberto; CAPITÃO, Cláudio Garcia. Sexualidade e trabalho na visão da psicanálise. In: FREITAS, Maria Ester; DANTAS, Marcelo (orgs.). Diversidade sexual e trabalho. São Paulo: Cengage Learning, 2012, p. 23.

${ }^{200}$ A cooperação no e para o trabalho, como mecanismo de socialização e integração, tem por premissas, (a) o consentimento dos envolvidos em abdicar, parcialmente que seja, da experiência com a própria inteligência e a subjetividade; e (b) o reconhecimento da importância das contribuições singulares de cada um para o todo. Ela demanda, enfim, um arrefecimento do individualismo em favor da coesão grupal, compatibilizando subjetividade e ação coletiva. (DEJOURS, op. cit., 2004, p. 32). 
Num mundo do trabalho de incerteza, desregulamentação e flexibilização, dissemina-se uma situação generalizada de precariedade, agravada pelo desmonte das redes sociais e econômicas de apoio ao trabalhador, que fica exposto a toda sorte de danos e violências ${ }^{201}$.

Conforme Dejours, são múltiplos os desdobramentos dessa precarização. Intensifica-se o trabalho e, com ele, o sofrimento subjetivo dos trabalhadores. Anulase a possibilidade de mobilização coletiva contra o sofrimento. $O$ trabalhador silencia quanto ao sofrimento e às injustiças experimentadas pelos outros, focando energias na própria resistência e na manutenção de sua instável colocação. A insegurança oriunda da ameaça contínua do desemprego, enfim, alimenta um crescente individualismo ${ }^{202}$.

O fenômeno, acrescenta Bourdieu, gera a desestruturação da existência e a degradação da relação com o mundo, o tempo e o espaço. Na era das dispensas cíclicas e do downsizing, não cabe falar em temporalidade. Vive-se em incerteza, na impossibilidade de projeções seguras sobre o futuro. O emprego é encarado como um privilégio instável, disponível a poucos, mas desejado por muitos - nenhum trabalhador é insubstituível e há concorrência pelo trabalho e no trabalho ${ }^{203}$.

A versão fragmentada e instável do trabalho torna distante a perspectiva integradora. A incerteza sobre a permanência no emprego e as pressões múltiplas sobre o trabalhador põem em xeque o seu sentimento de reconhecimento, de contribuição. Quando a sobrevivência no mercado de trabalho se torna um foco de preocupação constante, o coletivo é deixado de lado numa luta de todos contra todos $^{204}$.

Em outra frente, os trabalhadores são bombardeados por um discurso organizacional de teor quase publicitário, que insiste em negar o sofrimento vivenciado

\footnotetext{
${ }^{201}$ Esse conceito de precariedade é proposto por Judith Butler: "Precariedade designa uma condição induzida politicamente, na qual determinados grupos sofrem com a carência de redes sociais e econômicas de apoio, ficando diferenciadamente expostos a danos, à violência e à morte" (BUTLER, Judith. Frames of war: when is life grievable? London: Verso, 2009 , p. 25, tradução livre, no original: "Precarity designates that politically induced condition in which certain populations suffer from failing social and economic networks of support and become differentially exposed to injury, violence, and death").

202 DEJOURS, Cristophe. A banalização da injustiça social. 7. ed. Rio de Janeiro: Editora FGV, 2007, p. 50.

${ }^{203}$ BOURDIEU, Pierre. Contre-feux: propos pour servir à la résistance contre l'invasion néolibérale. Paris: Raison D’Agir, 1998, p. 96-98.

${ }^{204}$ ENRIQUEZ, Eugène. Perda do trabalho, perda da identidade. Cad. Esc. Leg., Belo Horizonte, 5(9), jul./dez. 1999, p. 67-68.
} 
e Ihes apresenta uma versão romantizada da realidade, em que o trabalho, humanizado, gera satisfação e felicidade ${ }^{205}$.

A respeito desse novo modelo, Marcia Hespanhol Bernardo observa que, "em vez de superar as contradições inscritas na organização taylorista - como costuma ser anunciado pelos defensores da organização flexível - essas empresas parecem obter apenas um acréscimo de fatores geradores de sofrimento" ${ }^{206}$.

O conjunto de ideias sob o qual operam as organizações empresariais contemporâneas, em que pese viabilize a exploração do obreiro em favor da maior rentabilidade do sistema, o faz ao custo da desarticulação do elo entre trabalho, subjetividade e coletividade. Enriquez assevera que esse modelo de gestão do trabalho tende a resultar em perversão social:

Poderão permanecer na empresa apenas aqueles que são considerados de excelente performance. (...) Isso remete às pessoas ditas vencedoras. São aqueles que matam de maneira tranqüila, sem dó, "fritando" o semelhante, um outro profissional. Mata-se de verdade e a pessoa lesada não tem idéia, nem a impressão de que querem matá-la. Isso é psicologização, na medida em que, se alguém não consegue conservar o seu trabalho, fala-se tranqüilamente: "mas é sua culpa, você não teve uma alma de vencedor, você não é um herói!" Isso quer dizer que é preciso ser um herói num cavalo branco para ganhar as coisas ou as guerras. Então, psicologização quer dizer: "você é culpado e não a organização da empresa ou da sociedade. A culpa é sua." Isso culpabiliza as pessoas de modo quase total, pessoas que, além disso, ficam submetidas a um estresse profissional extremamente forte. Então as empresas exigem daqueles que permanecem um devotamento, lealdade e fidelidade, mas ela não dá nada em troca. Ela vai dizer simplesmente: "você tem a chance de continuar, mas talvez você também não permaneça"207.

Nesse sentido, avalia Dejours, "o trabalho gera, então, sofrimento, frustração, sentimento de injustiça e, eventualmente, patologia. Ele se torna deletério e contribui para destruir a subjetividade, juntamente com as bases da saúde mental”208.

205 BERNARDO, Marcia Hespanhol. Trabalho duro, discurso flexível: uma análise das contradições do toyotismo a partir da vivência dos trabalhadores. São Paulo: Editora Expressão, 2009, p. 135-151.

${ }^{206}$ Ibid., p. 152.

207 ENRIQUEZ, Eugène. Perda do trabalho, perda da identidade. Cad. Esc. Leg., Belo Horizonte, 5(9), jul./dez. 1999, p. 65.

${ }^{208}$ DEJOURS, Cristophe. Subjetividade, trabalho e ação. Revista produção, v.14, n. 3, p. 2734, set./dez. 2004, p. 33. 
Se a "precariedade está hoje por toda a parte", como enfatiza Pierre Bourdieu $^{209}$, ela não se abate, porém, de forma idêntica sobre todos. Há, pois, em todo lugar e notadamente no trabalho, uma distribuição radicalmente desigual da precariedade. Algumas formas de vida estão mais protegidas do que outras. O sofrimento de determinados grupos não desperta tanta atenção e empatia como o sofrimento de outros. Algumas pessoas, afinal, por variados motivos, encontram-se mais expostas a danos e à violência ${ }^{210}$.

Entre os fatores que atuam na demarcação dessa linha que separa as "vidas que valem das que não valem a pena", é notória a influência de preconceitos e dos esquemas de pensamento que organizam hierarquicamente a existência humana. É a partir desse viés, portanto, que se procederá à análise da homossexualidade no mundo do trabalho contemporâneo.

\subsection{A homossexualidade na organização contemporânea do trabalho: da marginalização ao reconhecimento}

Ainda entranhadas na cultura ocidental, a despeito das rápidas mudanças promovidas na opinião pública desde o surgimento dos movimentos de defesa dos direitos dos homossexuais, as homofobias e o heterossexismo se reproduzem também no mundo do trabalho. Expressam-se nas performances de empregados e de empregadores, na organização do trabalho e, inclusive, na definição das estruturas organizacionais. Afinal, na condição de elemento central da vida, o trabalho preenche parte significativa do tempo e das relações interpessoais do sujeito contemporâneo, influenciando a construção de identidades, e, por essa razão, apresentando-se como "um microcosmo, um resumo da vida social"211.

Alguns fatores, entretanto, tornam o contexto organizacional particularmente propício à manifestação e à reprodução de práticas e hábitos homofóbicos. De um

\footnotetext{
${ }^{209}$ BOURDIEU, Pierre. Contre-feux: propos pour servir à la résistance contre l'invasion néolibérale. Paris: Raison D’Agir, 1998, p. 95, tradução livre, no original: “(..) la précarité est aujourd'hui partout'.

210 Para maiores informações sobre o tema da distribuição diferencial da precariedade, consultar BUTLER, Judith. Vida precaria: el poder del duelo y la violencia. Buenos Aires: Paidós, 2006.

${ }^{211}$ SANTOS, Dartagnan Ferrer dos Santos. Igualdade, diferença e identidade: três pilares da alteridade nas relações de trabalho de um mundo pluralista. In: BARZOTTO, Luciane Cardoso (Coord.). Trabalho e igualdade: tipos de discriminação no ambiente de trabalho. Porto Alegre: Livraria do Advogado Editora, 2012, p. 99.
} 
lado, há que se atentar para a influência que a divisão sexual do trabalho, fundada na perspectiva binária de gênero e na heteronormatividade, exerce na conformação dos modelos de produção e de organização do trabalho, bem como no ideal de trabalhador no qual ambos se amparam. De outro, cumpre destacar como as pressões contrárias à existência homossexual no mundo do trabalho impactam a subjetividade, a identidade e a saúde dos trabalhadores gays. Não menos importante, porém, é a exposição das contradições sobre as quais o sistema capitalista opera, ao condescender e até mesmo fomentar a reprodução de posturas anti-homossexuais que impõem custos e perdas às próprias organizações empresariais.

\subsubsection{Outsiders ${ }^{212}$ nas organizações empresariais: masculinidade, heterossexismo e trabalho}

No campo das Ciências Sociais, particularmente entre teóricos da masculinidade e expoentes das correntes feministas, há um relativo consenso de que o gênero ${ }^{213}$ é uma construção essencialmente social e relacional, sujeita a negociações e transformações ${ }^{214}$.

Culturalmente, no entanto, esse conjunto de expectativas, prescrições, atributos, preferências e comportamentos integram noções opostas de feminino e masculino, vistas não apenas como fixas e rígidas, mas também como uma derivação natural do sexo biológico. Para o senso comum, pessoas de sexo masculino normalmente se comportam de acordo com as noções sociais relacionadas à masculinidade e, consequentemente, sentem-se sexualmente atraídas por mulheres. No sentido oposto, pessoas nascidas no sexo feminino desenvolveriam conduta

\footnotetext{
${ }^{212}$ Emprega-se, aqui, o termo outsider no sentido a ele atribuído por Elias e Scotson, como forma de designar um grupo estigmatizado, nas relações de poder desiguais entre grupos, em contraposição ao grupo dominante, denominado estabelecido (ELIAS, Norbert; SCOTSON, John L. Os estabelecidos e os outsiders: sociologia das relações de poder a partir de uma pequena comunidade. Rio de Janeiro: Jorge Zahar Editor, 2000).

${ }^{213}$ Segundo Jorber, o gênero é uma "(...) instituição social que estabelece padrões de expectativas para os indivíduos, ordena os processos sociais da vida cotidiana, é construído nas grandes organizações sociais da sociedade, tais como a economia, a ideologia, a família e a política; e é também uma entidade em si" (JORBER, Judith. Beyond the binaries: depolarizing the categories of sex, sexuality, and gender. Sociological Inquiry, v. 66, n. 2, p. 143-160, Abr. 1996, p. 146-147, tradução livre, no original: "[...] a social institution that establishes patterns of expectations for individuals, orders the social processes of everyday life, is built into the major social organizations of society, such as the economy, ideology, the family, and politics, and is also an entity in and of itself').

${ }^{214}$ MCGINLEY, Ann C. Creating masculine identities: bullying and harassment "because of sex". University of Colorado Law Review, v. 79, 2008, p. 1161.
} 
afinada com o que a sociedade atribui à feminilidade, sentindo-se sexualmente atraídas por homens ${ }^{215}$.

Essa visão de mundo se organiza em torno da classificação daquilo que é cognoscível entre as esferas do masculino e do feminino, estruturando um sistema de oposições homólogas (ativo/passivo, razão/sensibilidade, público/privado, produção/reprodução, força/fraqueza), em que cada componente se vincula a um desses polos ${ }^{216}$. A concepção binária de gênero, por conseguinte, essencializa determinadas formas de ser e naturaliza diferenças socialmente forjadas entre os gêneros, ao mesmo tempo em que desloca para a marginalidade, como antinatural, o que não se enquadra nesse padrão: homossexuais, homens afeminados, mulheres masculinizadas ou transgêneros ${ }^{217}$.

A oposição masculino-feminino, entretanto, não se processa de forma neutra. Cuida-se de um sistema dinâmico e assimétrico que, além de rejeitar o que o transgrede, sustenta historicamente uma prevalência do homem sobre a mulher. A dominação masculina engendra a hierarquização dos sexos e atrela à masculinidade vantagens, prerrogativas, status e funções de prestígio interditadas ao universo feminino, tais como o controle da política e da violência, o acesso ao trabalho e o recebimento de melhores remunerações ${ }^{218}$. A masculinidade, esse "lugar simbólico/imaginário de sentido estruturante nos processos de subjetivação"219, conforma os referenciais a partir dos quais os homens se inserem na estrutura das relações de gênero, em um patamar diferenciado daquele ocupado pelas mulheres e pelo feminino 220 .

Essas relações de dominação se mantêm a partir de um processo contínuo e difuso de socialização, desde a mais tenra idade, por meio de práticas e discursos, estímulos e censuras. Para pensar a própria realidade, dominantes e dominados se

\footnotetext{
${ }^{215}$ MCGINLEY, Ann C. Creating masculine identities: bullying and harassment "because of sex". University of Colorado Law Review, v. 79, 2008, p. 717.

${ }^{216}$ BOURDIEU, Pierre. La dominación masculina. Barcelona: Editorial Anagrama, 2000, p. 20-21.

217 MCGINGLEY, Ann C. Erasing boundaries: masculinities, sexual minorities, and employment discrimination. University of Michigan Journal of Law Reform, v. 43:3, p. 718. ${ }^{218}$ ECCEL, Cláudia Sirangelo; ALCADIPANI, Rafael. (Re)descobrindo as masculinidades. In: FREITAS, Maria Ester; DANTAS, Marcelo (orgs.). Diversidade sexual e trabalho. São Paulo: Cengage Learning, 2012, p. 52-53.

${ }^{219}$ OLIVEIRA, Pedro Paulo de. A construção social da masculinidade. Belo Horizonte: Editora UFMG, 2004, p. 13.

${ }^{220}$ A respeito, consultar: BOURDIEU, op. cit., 2000.
} 
valem das categorias e expectativas reproduzidas pelas estruturas de dominação nas quais estão inseridos. Desse modo, seus atos de conhecimento são, também, atos de submissão e de legitimação dessas estruturas ${ }^{221}$. A dominação masculina, portanto, assume um viés de violência simbólica e se exerce, muitas vezes, com a cumplicidade daqueles que são subordinados ${ }^{222}$.

A identidade masculina, todavia, é um constructo bastante frágil, na medida em que se define essencialmente pela negação contínua do feminino e depende da aprovação dos outros para se manter ${ }^{223}$. Todo homem atravessa, ao longo de sua vida, um processo de aprendizagem e afirmação do masculino. Trata-se de uma educação que se faz por mimetismo e pelo sofrimento. Um mimetismo de violências contra si mesmo, moldando corpo e personalidade aos ideais da masculinidade; e contra os outros, simultaneamente, pois o masculino deve ser comprovado, nas disputas de poder entre homens ${ }^{224}$.

O "homem de verdade", para fazer jus a esse título, precisa assumir um papel socialmente legitimado e executá-lo ininterruptamente diante de uma plateia de críticos atentos e rigorosos. Qualquer deslize traz em si o risco da desclassificação, de ser tratado como um não-homem ${ }^{225}$.

${ }^{221}$ BOURDIEU, Pierre. La dominación masculina. Barcelona: Editorial Anagrama, 2000, p. 27.

${ }^{222}$ Segundo Pierre Bourdieu, a violência simbólica “(...) se institui por intermédio da adesão que o dominado não pode deixar de conceder ao dominante (e, portanto, à dominação) quando ele não dispõe, para pensá-la e para se pensar, ou melhor, para pensar sua relação com ele, mais que de instrumentos de conhecimento que ambos têm em comum e que, não sendo mais que a forma incorporada da relação de dominação, fazem esta relação ser vista como natural; ou, em outros termos, quando os esquemas que ele põe em ação para se ver e se avaliar, ou para ver e avaliar os dominantes (elevado/baixo, masculino/feminino, branco/negro etc.), resultam da incorporação de classificações, assim naturalizadas, de que seu ser social é produto" (Ibid., p. 51, tradução livre, no original: "se instituye a través de la adhesión que el dominado se siente obligado a conceder al dominador (por consiguiente, a la dominación) cuando no dispone, para imaginarla o para imaginarse a sí mismo o, mejor dicho, para imaginar la relación que tiene con él, de otro instrumento de conocimiento que aquel que comparte con el dominador y que, al no ser más que la forma asimilada de la relación de dominación, hacen que esa relación parezca natural; o, en otras palabras, cuando los esquemas que pone en práctica para percibirse y apreciarse, o para percibir y apreciar a los dominadores (alto/bajo, masculino/femenino, blanco/negro, etc.), son el producto de la asimilación de las clasificaciones, de ese modo naturalizadas, de las que su ser social es el producto").

${ }^{223}$ Ibid.

224 WELZER-LANG, Daniel. A construção do masculino: dominação das mulheres e homofobia. Revista Estudos Feministas, vol.9, n.2, 2001, p. 462-463.

${ }^{225}$ Ibid., p. 463. 
A virilidade é um dos principais atributos constitutivos dos modelos hegemônicos de masculinidade ${ }^{226}$. Segundo Bourdieu, ela é compreendida "como capacidade reprodutiva, sexual e social, mas também como aptidão ao combate e ao exercício da violência" 227 . No jogo de oposições vinculadas à dualidade masculino/feminino, os homens viris hão de ser fortes, corajosos e racionais; jamais fracos, covardes e vulneráveis a sentimentos - "imperfeições" que denunciam feminilidade. A virilidade é, portanto, "construída diante dos outros homens, para os outros homens e contra a feminilidade, em uma espécie de medo do feminino" 228 e, vale acrescentar, da homossexualidade.

Aquele que apresenta características ou trejeitos convencionalmente atribuídos ao feminino falha nesses testes e corporifica o equivalente simbólico da mulher, no universo masculino, descendo ao nível mais baixo da hierarquia das masculinidades: o dos homossexuais. As masculinidades hegemônicas, afinal, se impõem mediante um processo de demarcação, desqualificação e desvalorização do diferente, do que não se enquadra em seus padrões: o feminino e o afeminado. Essas configurações do masculino podem se reproduzir mediante recursos simbólicos ou valer-se, em alguns casos, da força e da violência; sendo mantidas e reproduzidas tanto por indivíduos, quanto por grupos e por instituições, como a escola e o mercado de trabalho 229 .

É nesse sentido que, em se havendo costurado, pela construção de estereótipos, uma ligação entre homossexualidade e feminilidade (não necessariamente verdadeira), "a homofobia engessa as fronteiras de gênero" ${ }^{230}$,

\footnotetext{
${ }^{226}$ A masculinidade hegemônica designa uma forma dominante de masculinidade que, em dado contexto espaço-temporal, se apresenta como resposta legítima à manutenção da estrutura social patriarcal - a ascendência e o controle social, simbólico e sexual, dos homens sobre as mulheres. Aqueles que não se mostram capazes de encarná-la, nas performances de gênero, expressam formas subordinadas de masculinidade. MCGINGLEY, Ann C. Erasing boundaries: masculinities, sexual minorities, and employment discrimination. University of Michigan Journal of Law Reform, v. 43:3, p. 722.

${ }^{227}$ BOURDIEU, Pierre. La dominación masculina. Barcelona: Editorial Anagrama, 2000, p. 68, tradução livre, no original: "como capacidad reproductora, sexual y social, pero también como aptitud para el combate y para el ejercicio de la violencia".

${ }^{228}$ Ibid., p. 71, tradução livre, no original: "construido ante y para los restantes hombres y contra la feminidad, en una especie de miedo de lo femenino, y em primer lugar en sí mismo". ${ }^{229}$ ECCEL, Cláudia Sirangelo; ALCADIPANI, Rafael. (Re)descobrindo as masculinidades. In: FREITAS, Maria Ester; DANTAS, Marcelo (orgs.). Diversidade sexual e trabalho. São Paulo: Cengage Learning, 2012, p. 55-56.

230 WELZER-LANG, Daniel. A construção do masculino: dominação das mulheres e homofobia. Revista Estudos feministas, vol.9, n.2, 2001, p. 464-465.
} 
atuando como mecanismo de controle, na relação entre homens, a fim de resguardar a dominação masculina e a manifestação hegemônica da masculinidade em um determinado contexto social. A esse respeito, McGinley assevera que a homofobia denota mais do que um temor de ser identificado como homossexual:

É um medo de que outros homens reconheçam que certos indivíduos
não são tão masculinos quanto desejam aparentar. Esse medo gera
vergonha e induz uma indisposição para dar apoio a outros que sejam
vítimas desse tipo de assédio. Outrossim, ele compele os homens a
expressarem comportamentos masculinos exagerados e a assumir a
postura de que mulheres e gays são "o outro" com o qual devem se
comparar a fim de estabelecer a própria masculinidade ${ }^{231}$.

A divisão sexual do trabalho, isto é, as formas como, variadamente no tempo e no espaço, o trabalho social é repartido em função das relações sociais entre os $\operatorname{sexos}^{232}$, é uma das principais manifestações dessa ordem social construída a partir da dicotomia masculino/feminino e da prevalência de determinadas formas de masculinidade sobre outras.

O mundo do trabalho, enquanto parte integrante e central da socialização humana na pós-modernidade, não escapa às relações de dominação que organizam a vida social. Nesse sentido, ainda que de forma invisível, encontram-se imbricados na própria estrutura das organizações empresariais pressuposições de gênero e de sexualidade.

Segundo Hirata e Kergoat, embora se observe alguma plasticidade em sua aplicação, mormente a partir da integração mais acentuada da mulher no contexto laboral, o trabalho social se organiza com base em dois princípios: o da separação (há trabalhos adequados para homens e trabalho adequados para mulheres) e o hierárquico (os trabalho "de homem" gozam de valor social maior do que os pertinentes à mulher $)^{233}$.

Essas expectativas ainda atuais reproduzem a repartição tradicional de papéis na família, segundo a qual as mulheres são incumbidas de atividades de viés

\footnotetext{
${ }^{231}$ MCGINLEY, Ann C. Creating masculine identities: bullying and harassment "because of sex". University of Colorado Law Review, v. 79, 2008, p. 1161-1162, tradução livre, no original: "It is a fear that other men will recognize that men are not as masculine as they pretend to be. This fear creates shame and leads to an unwillingness to stand up for others who are being harassed. Moreover, it compels men to enact exaggerated masculine behaviors and to project attitudes that women and gays are 'the other' with whom men compare themselves in order to establish their own 'manhood".

${ }^{232}$ HIRATA, Helena; KERGOAT, Danièle. Novas configurações da divisão sexual do trabalho.
} Cadernos de Pesquisa, v. 37, n. 132, p. 595-609, set./dez. 2007, p. 599.

${ }^{233}$ Ibid., p. 599-600. 
reprodutivo, de cuidado e de auxílio, típicas do âmbito doméstico; ao passo que os homens estariam voltados para atividades da esfera pública, engajando-se nas atividades produtivas, de gestão, e de maior valor e prestígio ${ }^{234}$.

Segundo Eccel e Alcadipani, "o corpo próprio para o trabalho foi concebido com base no ideal do corpo masculino, disciplinado, desvinculado da reprodução, emocionalmente controlado e disponível para a produção" ${ }^{235}$. A ideia de trabalhador que pode dedicar boa parte de seu tempo à empresa foi construída tendo por base uma estrutura social calcada na família nuclear burguesa heterossexual, em que, ocupando-se a mulher das obrigações domésticas, o homem poderia atuar livremente como único provedor. O trabalhador-modelo, nesses termos, comprometido com o crescimento pessoal e da empresa, é homem e performa uma masculinidade hegemônica que, em boa parte dos ambientes organizacionais tende a ser agressiva, competitiva, autoritária e carreirista ${ }^{236}$.

De fato, os valores que orientam as organizações empresariais são, basicamente, atributos que o senso comum relaciona à masculinidade: racionalidade, potência, liderança, competitividade. Os próprios modelos de produção e de gestão do trabalho formulados desde a Revolução Industrial cuidam do trabalho como atividade eminentemente racional e objetiva (e, por assim dizer, masculina), de cuja organização depende a eficiência do empreendimento ${ }^{237}$. A cultura ocidental, portanto, acolhe e confere privilégios aos obreiros que se amoldam a uma postura dominante, provando continuamente a sua masculinidade, mas subordina e até mesmo exclui o trabalhador incompatível com as configurações normativas do masculino ${ }^{238}$.

Em síntese, o mercado de trabalho foi concebido por homens heterossexuais para homens heterossexuais, sendo potencialmente heteronormativo e sexista. Mulheres, minorias sexuais ou homens sem aptidão para perfomar a expressão dominante do masculino são forasteiros e têm de barganhar seu acesso e sua permanência nesse espaço.

${ }^{234}$ ECCEL, Cláudia Sirangelo; ALCADIPANI, Rafael. (Re)descobrindo as masculinidades. In: FREITAS, Maria Ester; DANTAS, Marcelo (orgs.). Diversidade sexual e trabalho. São Paulo: Cengage Learning, 2012, p. 65.

235 Ibid., p. 61.

${ }^{236}$ MCGINLEY, Ann C. Creating masculine identities: bullying and harassment "because of sex". University of Colorado Law Review, v. 79, 2008, p. 1161-1162.

${ }^{237}$ ECCEL; ALCADIPANI; op. cit. p. 60-64.

${ }^{238}$ MCGINLEY, op. cit., p. 1162. 
É bem verdade que a masculinidade hegemônica, no Ocidente, principalmente nos países de capitalismo central, vem passando por transformações, em grande medida, influenciadas pelos processos de globalização, de crescimento da economia financeirizada e de fortalecimento das empresas multinacionais. Nesse passo, tem ganhado proeminência, nos últimos anos, o modelo masculino do executivo nômade, hiperconectado e egocêntrico. O discurso corrente dessa nova geração masculina, fazendo eco à imagem progressista divulgada pelas organizações contemporâneas, ganha pinceladas de tolerância à diversidade. A realidade do contexto organizacional, no entanto, não se revela tão receptiva - sobretudo em países nos quais as masculinidades marcadamente viris ainda ostentam grande prestígio $^{239}$.

Aliás, Hirata e Kergoat asseveram que o ideal de trabalho flexível promovido pelos modelos de gestão atuais pode, na verdade, "reforçar as formas mais estereotipadas das relações sociais de sexo" 240 .

Com efeito, rememore-se que, com vistas à uma suposta eficiência econômica, os modelos contemporâneos de gestão do trabalho se valem, com certa frequência, do desrespeito rotineiro e institucionalizado às normas trabalhistas, das dispensas cíclicas e, também, da ameaça, da manipulação, da disseminação de práticas e designações discriminatórias; práticas que, em alguma medida, contam com a colaboração ativa ou não de outros obreiros - o que Dejours denomina a banalização da injustiça social: "a tolerância, a não denúncia e a participação em se tratando de injustiça e do sofrimento infligidos a outrem"241.

Se trabalhar é confrontar-se continuamente com a possibilidade de sofrimento, o é de forma mais acentuada no cenário de insegurança neoliberal ${ }^{242}$. Nesse rumo, os trabalhadores são levados a adotar coletivamente mecanismos de

${ }^{239}$ ECCEL, Cláudia Sirangelo; ALCADIPANI, Rafael. (Re)descobrindo as masculinidades. In: FREITAS, Maria Ester; DANTAS, Marcelo (orgs.). Diversidade sexual e trabalho. São Paulo: Cengage Learning, 2012, p. 71-72.

240 HIRATA, Helena; KERGOAT, Danièle. Novas configurações da divisão sexual do trabalho. Cadernos de Pesquisa, v. 37, n. 132, p. 595-609, set./dez. 2007, p. 600.

${ }^{241}$ DEJOURS, Cristophe. A banalização da injustiça social. 7. ed. Rio de Janeiro: Editora FGV, 2007, p. 76.

${ }^{242}$ Conforme Dejours, o sofrimento no trabalho contemporâneo transparece na negação estratégica e intencional, pelas empresas, da resistência do real do trabalho às prescrições, pondo em dúvida as competências individuais; nas pressões contraditórias que a organização imprime sobre os trabalhadores, constrangendo-os à má execução de suas atribuições; ou, ainda, no déficit de retribuição simbólica pela contribuição pessoal vertida à organização, traduzida em insuficiência de reconhecimento (Ibid., p. 29-34). 
defesa destinados a evitar a descompensação psicológica, uma consequência natural do sofrimento agudo sobre a saúde mental ${ }^{243}$.

Para resistir, pois, é preciso calar o próprio sofrimento e tornar-se cego ao sofrimento alheio. Nesse específico, Dejours sinaliza que a virilidade é um recurso simbólico que permite essa racionalização do mal e a manutenção do equilíbrio psíquico dos trabalhadores, transformando em valor, nas organizações, o que seria falta moral em outros contextos ${ }^{244}$.

A virilidade, enquanto valor, concerne à capacidade pessoal para exercer o poder, valendo-se da força e causando sofrimento a outrem, se necessário ${ }^{245}$. Imposta, aprendida e reconhecida pelos homens, ela serve não apenas como modo de diferenciá-los das mulheres, mas também como forma de distinção hierárquica entre os próprios homens. Afinal, o "homem de verdade" não se expressa sobre as dificuldades e angústias que o trabalho lhe causa, tendo como valores caros 0 autocontrole emocional, a frieza na execução das tarefas e uma esperada clivagem entre suas vidas profissional e pessoal ${ }^{246}$. O sujeito viril domina, portanto, a si e aos outros. É aquele que sobrepuja o próprio sofrimento, não se abala perante o sofrer alheio e se mostra preparado para desempenhar qualquer função que lhe seja designada no âmbito do trabalho, mesmo que em prejuízo de outros trabalhadores.

Nesse sentido, a ativação coletiva de uma virilidade defensiva, no contexto do trabalho flexível e desregulamentado, reforça a coesão obreira em torno de uma identidade masculina compartilhada. Num ambiente em que provar-se viril é um requisito para ser aceito, o medo de se passar por não-homem (logo, vinculado ao feminino) ao deixar de corresponder às exigências do trabalho, isto é, da ameaça de castração simbólica, é o que une os trabalhadores e os permite negar uma realidade de sofrimentos e injustiças ${ }^{247}$. Como destaca Molinier:

A virilidade se transforma em um recurso simbólico capital para a
coesão do coletivo defensivo. Um homem de verdade não teme o
perigo. Ele tem o controle de si mesmo e deve ser capaz de prová-lo
a todo momento aos seus colegas se quiser conquistar e manter a sua
confiança. Um homem que não consegue dominar seu medo ou sua
vulnerabilidade é ridicularizado pelos outros, desprezado como um

${ }^{243}$ DEJOURS, Cristophe. A banalização da injustiça social. 7. ed. Rio de Janeiro: Editora FGV, 2007, p. 35.

244 lbid., p. 81.

245 Ibid., p. 81.

${ }^{246}$ MOLINIER, Pascale. Virilité défensive, masculinité créatrice. Travail, genre et sociétés, n. 3, p. 25-44, mar. 2000, p. 26-31.

${ }^{247}$ DEJOURS, op. cit., p. 82. 
"maricas" ou "efeminado" até que, alcançando seu limite, vai embora ou fica doente ${ }^{248}$.

Justapondo-se a imagem do homem viril à do próprio trabalhador, a virilidade defensiva insufla uma hipermasculinidade de bases heterossexistas e põe em xeque a competência e a aptidão de homossexuais e homens não viris (e, por oposição, afeminados) para o trabalho, instigando, assim, reações coletivas de viés homofóbico contra esses obreiros ${ }^{249}$.

Quem escapa ao arquétipo viril, demonstra ou aparenta vulnerabilidade, é descoberto ou espontaneamente se revela homossexual, estremece o esquema andro e heterocentrado que dá suporte à coesão grupal, à negação coletiva da realidade e à justificação das violências cotidianas do trabalho. Esses outsiders tornam-se, enfim, alvo de assédio, rejeição e perseguição: uma válvula de escape para as frustrações e angústias que o mecanismo de defesa da virilidade busca ocultar.

\subsubsection{Quando o não dito se converte em atos: a discriminação de homens gays no mundo do trabalho}

O trabalho, enquanto importante espaço de socialização da pós-modernidade, construiu-se e ainda se mantém, em larga medida, à vista de uma cultura baseada na dominação masculina e na heteronormatividade. De acordo com esse sistema, a divisão social do trabalho situa as atividades produtivas, de liderança e de prestígio social como o locus por excelência de um trabalhador que é homem e heterossexual. Noutro giro, a organizações contemporâneas têm encampado modelos de gestão que, apesar de anunciarem o contrário, não apenas banalizam o sofrimento e o cometimento de injustiças no trabalho, como se fossem reflexos inevitáveis da guerra econômica, mas também estimulam a adoção de estratégias defensivas, pelos obreiros, ancoradas na exaltação coletiva da virilidade e, consequentemente, da

\footnotetext{
${ }^{248}$ MOLINIER, Pascale. Virilité défensive, masculinité créatrice. Travail, genre et sociétés, $\mathrm{n}$. 3 , p. $25-44$, mar. 2000 , p. 30 , tradução livre, no original: "La virilité s'avère une ressource symbolique capitale pour la cohésion du collectif défensif. Un homme, un 'vrai', ne craint pas le danger. Il se maîtrise et doit être en mesure de le prouver à tout bout de champ devant ses collègues s'il veut gagner, et conserver leur confiance. Un homme qui ne parvient pas à contrôler sa peur ou sa vulnérabilité est raillé par les autres, méprisé comme une 'chochotte' ou une 'femmelette', jusqu'à ce qu'il craque et qu'il s'en aille ou tombe malade".

249 MCGINGLEY, Ann C. Erasing boundaries: masculinities, sexual minorities, and employment discrimination. University of Michigan Journal of Law Reform, v. 43:3, p. 722723.
} 
desvalorização de todo trabalhador que não se adeque a esse modelo de masculinidade agressiva e marcadamente contrária ao feminino. Nesse sentido, 0 espaço do trabalho se mostra, ainda hoje, um ambiente particularmente propício à origem e à profusão de posturas, práticas e discursos de viés anti-homossexual, quando não abertamente homofóbicos.

A discriminação contra homossexuais, no âmbito do trabalho, é constatada por uma variedade de estudos. Trata-se de um campo acadêmico sólido em países como os Estados Unidos, mas em relação ao qual os pesquisadores brasileiros vêm muito recentemente voltando sua atenção ${ }^{250}$.

Segundo Croteau, a discriminação por orientação sexual no trabalho pode ser classificada como formal ou informal. São formais aquelas práticas e procedimentos institucionalizados que visam a restringir o acesso a vantagens (simbólicas e econômicas) oriundas do trabalho. Nessa linha, se enquadram medidas como a negativa de contratação; a imposição de barreiras à ascensão profissional ou aos aumentos salariais; a recusa à atribuição de novas responsabilidades; a não extensão, a companheiros de trabalhadores homossexuais, de benefícios gozados por parceiros de empregados heterossexuais; e a diferença de remuneração entre trabalhadores homo e heterossexuais que desempenham as mesmas funções. Já a discriminação informal é traduzida em violências normalmente indiretas e, por vezes, toleradas no ambiente de trabalho, como o assédio moral ou as agressões pontuais (físicas ou psicológicas) perpetradas por superiores ou colegas ${ }^{251}$.

\footnotetext{
${ }^{250}$ Garcia cita, como exemplo, pesquisas conduzidas por Siqueira, Ferreira e Zauli-Fellows, (SIQUEIRA, M.V.S.; FERREIRA, R.C.; ZAULI-FELLOWS, A. Gays no ambiente de trabalho: uma agenda de pesquisa. In: ENANPAD, XXX, 2006, Bahia. Trabalhos Apresentados. Salvador, 2006); Irigaray, (IRIGARAY, H.A. Políticas de diversidade nas organizações: uma questão de discurso? In: ENANPAD, 31, 2007, Rio de Janeiro. Trabalhos apresentados. Rio de Janeiro, 2007; IRIGARAY, H.A. A. Estratégia de sobrevivência dos gays no ambiente de trabalho. In: ENANPAD, 31, 2007, Rio de Janeiro. Trabalhos apresentados. Rio de Janeiro, 2007); Ferreira e Siqueira (FERREIRA, R.C.; SIQUEIRA, M.V.S. O gay no ambiente de trabalho: análise dos efeitos de ser gay nas organizações contemporâneas. In: ENANPAD, 31, 2007, Rio de Janeiro. Trabalhos apresentados. Rio de Janeiro, 2007.); e Eccel e FloresPereira (ECCEL, C.S.; FLORES-PEREIRA, M.T. A inserção da "diversidade" homossexual em uma livraria de shopping Center: um estudo crítico. In: ENANPAD, 32, 2008, Rio de Janeiro. Trabalhos apresentados. Rio de Janeiro, 2008.). A respeito, consultar: GARCIA, Agnaldo; SOUZA, Eloisio Moulin de. Sexualidade e trabalho: estudo sobre a discriminação de homossexuais masculinos no setor bancário. Revista de Administração Pública - RAP, v. 44, n. 6, p. 1353-77, nov./dez. 2010, p. 1362.

${ }^{251}$ CROTEAU, James M. Research on the work experiences of lesbian, gay, and bisexual people: an integrative review of methodology and findings. Journal of vocational behavior, n. 48 , p. 195-209, 1996, p. 198-199.
} 
No que concerne à discriminação no acesso ao emprego, tem-se que a ciência (ou a mera suspeita) do empregador quanto à homossexualidade dos interessados na vaga em disputa pode servir de barreira à contratação. Daí porque a inclusão, nos formulários dos processos seletivos, de informações acerca da vida privada dos candidatos, como a existência de companheiros ou detalhes sobre a configuração familiar, representa um potencial risco à inserção profissional desses indivíduos ${ }^{252}$.

Os dados colhidos por Drydakis, junto ao mercado de trabalho ateniense, na Grécia, corroboram a existência de barreiras específicas ao ingresso de homossexuais no mercado de trabalho. Sua pesquisa evidenciou que a probabilidade de um candidato supostamente gay ser convocado para uma entrevista de emprego é aproximadamente $26 \%$ menor que a de um candidato heterossexual em condições parecidas. Essa chance, porém, se torna 34,8\% menor se o empregador for do sexo masculino, o que denota uma maior propensão dos homens a discriminar outros homens homossexuais ${ }^{253}$.

Desdobramentos similares foram observados por Tilcsik, em larga escala, nos Estados Unidos. A pesquisa apurou um diferencial de $40 \%$ na possibilidade de homens gays serem convocados para entrevistas, em comparação com heterossexuais. Nesse rumo, estatisticamente, um homossexual em busca de emprego precisaria se candidatar, no mínimo, a 14 vagas para receber uma resposta positiva, ao passo que, para heterossexuais, seriam necessárias apenas 9 tentativas. A variação percebida nesse percentual, a depender da região do país, sugere que a promulgação de leis voltadas ao combate à discriminação por orientação sexual exerce algum grau de influência na construção de um mercado de trabalho mais receptivo aos homossexuais, em alguns Estados, do que em outros ${ }^{254}$. A partir dos resultados obtidos, Tilcsik observa, ainda, uma tendência de os empregadores se

252 OIT. ORGULLO (PRIDE) en el trabajo: un estudio sobre la discriminación en el trabajo por motivos de orientación sexual e identidad de género en Argentina. Genebra: OIT, 2015, p. 28.

${ }^{253} \mathrm{O}$ estudo conduzido por Drydakis pautou-se na submissão, a ofertas de emprego reais em aberto, de pares de currículos de candidatos ficíticios, com capital humano praticamente idêntico, em que apenas um deles fazia constar informação sugestiva de homossexualidade - como, por exemplo, a participação em grupos de defesa de direitos LGBT. DRYDAKIS, Nick. Sexual orientation discrimination in the labour market. Labour economics, v. 16, p. 364372, 2009, p. 369-370.

${ }^{254}$ TILCSIK, András. Pride and prejudice: discrimination against openly gay men in the United States. American journal of sociology, v. 117, n. 2, p. 585-626, 2011, p. 605-609. 
valerem do estereótipo do homem homossexual (feminino e com baixa performance no trabalho) como subsídio para a tomada de decisões a respeito da contratação, preterindo candidatos gays, quando se tem em mira trabalhadores assertivos e comprometidos, ou se a atividade em questão é culturalmente compreendida como masculina ${ }^{255}$.

No Brasil, a influência de estereótipos em relação à homossexualidade, no que toca à aptidão para o desempenho de certas funções, foi constatada em pesquisa de opinião realizada pelo IBOPE Inteligência, no ano de 2011. À época, 15\% dos entrevistados (21\% dos homens e $9 \%$ das mulheres) posicionaram-se totalmente contra a atuação de homossexuais como policiais, profissão usualmente vinculada a um conjunto de atributos considerados masculinos, como a coragem e a agressividade. No mesmo levantamento, $8 \%$ se disseram contrários à atuação de gays como médicos e $14 \%$, como professores de ensino fundamental ${ }^{256}$.

A diferença salarial entre homens gays e heterossexuais com históricos profissionais e qualificação semelhantes é outra assimetria enfrentada por homossexuais no mundo do trabalho. De acordo com relatório da Organização Internacional do Trabalho, de 2011, a discriminação homofóbica seria causa de uma disparidade de remuneração entre trabalhadores na proporção de 3\% a 30\% ${ }^{257}$.

Lee Badgett, procedendo a uma revisão dos estudos sobre a diferença salarial motivada por orientação sexual nos Estados Unidos, concluiu que homens gays e bissexuais recebem, em média, de $13 \%$ a $32 \%$ menos do que trabalhadores heterossexuais. A interpretação dessas desigualdades, na quase totalidade das pesquisas, tem se encaminhado em duas direções: ou são compreendidas como resultado direto de discriminação contra homossexuais no mercado de trabalho, ou como uma consequência, em geral, da não conformidade dos trabalhadores gays aos papéis binários de gênero ${ }^{258}$.

${ }^{255}$ TILCSIK, András. Pride and prejudice: discrimination against openly gay men in the United States. American journal of sociology, v. 117, n. 2, p. 585-626, 2011, p. 616.

256 IBOPE - Inteligência. União estável entre homossexuais, 2011. Disponível em: $<\mathrm{http}: / / \mathrm{www}$.ibopeinteligencia.com/arquivos/antigos/casamentogay.pdf $>$. Acesso em $9 \mathrm{de}$ março de 2016.

257 OIT. Igualdade no trabalho: um desafio contínuo. Relatório Global no quadro do seguimento da Declaração sobre os Princípios e Direitos Fundamentais no Trabalho. Genebra: OIT, 2011, p. 57.

${ }^{258}$ Lee Badgett frisa que as pesquisas sobre a remuneração de mulheres lésbicas apresentam resultados menos consistentes do que aqueles colhidos em relação a homens gays. Enquanto boa parte dos pesquisadores não vislumbra diferenças salariais entre mulheres com 
Já em termos de ascensão profissional, de acordo com Souza e Pereira, as dificuldades enfrentadas se traduzem em dois cenários: ou é negado o acesso a funções gerenciais aos homens homossexuais ou, quando as conquistam, são alocados em postos de menor importância no conjunto do empreendimento ${ }^{259}$.

Há de se levar em conta igualmente que, na disputa por promoções, os trabalhadores dependem não apenas de qualificação e competência, sendo um diferencial igualmente importante a construção de bons relacionamentos com os colegas de trabalho e, especialmente, com os superiores hierárquicos. Homossexuais assumidos e não assumidos podem ficar em desvantagem nesse quesito, em virtude das barreiras que a homossexualidade ergue para o convício social com os outros homens da empresa, seja no ambiente de trabalho ou fora dele. Gays assumidos, os não-homens da concepção viril do masculino, tendem a ser rejeitados e excluídos dos espaços de socialização masculina, ao passo que os que ocultam sua identidade podem estrategicamente evitar esses mesmos espaços como forma de defesa, reduzindo ao mínimo necessário o contato com outros trabalhadores, a fim de resguardar o seu segredo. Esse quadro é apresentado no relato de um dos entrevistados por Souza e Pereira:

Desde a época no banco, você vê as pessoas com ascensão, as pessoas que têm convívio com gerentes, com as pessoas de escala mais alta e que são essas que têm aquela roda de amigos pra beber no bar, pra jogar um futebol, e que você não tem esse convívio com essa pessoa. Então, você vê que você fica pra trás, né? Que você não tem essa disponibilidade, esse convívio com eles. Então, acho que atrapalhou bastante ${ }^{260}$.

Ainda sob um viés formal, sobretudo nos países que não há o reconhecimento legal das uniões entre pessoas do mesmo sexo, outra forma de discriminação institucionalizada é a negativa de extensão, aos parceiros de empregados homossexuais, de benefícios concedidos pelas empresas aos parceiros de

diferentes orientações sexuais, outros tantos chegam a registrar patamares salariais superiores de trabalhadoras lésbicas em comparação às obreiras heterossexuais, o que parece indicar que há uma dinâmica diferenciada no funcionamento da discriminação por orientação sexual, no tocante ao trabalho da mulher. LEE BADGETT, M. V. Discrimination based on sexual orientation: a review of the literature in economics and beyond. In: LEE BADGETT, M. V.; FRANK, Jefferson. Sexual orientation discrimination: an international perspective. New York: Routledge, 2007, p. 29-34.

259 SOUZA, Eloisio Moulin de.; PEREIRA, Severino Joaquim Nunes. (Re)produção do heterossexismo e da heteronormatividade nas relações de trabalho: a discriminação de homossexuais por homossexuais. Revista de Administração Mackenzie - RAM, v. 14, n. 4, p. 76-105, jul./ago. 2013, p. 95.

${ }^{260}$ Ibid., p. 96. 
trabalhadores heterossexuais. Isso abrange, entre outros, a inclusão dos companheiros em planos de saúde, a concessão de licenças em caso de enfermidade ou falecimento na família, e os seguros de vida ${ }^{261}$.

Em que pese a gravidade de todas essas modalidades de discriminação, as agressões contra trabalhadores homossexuais mais recorrentes, no contexto do trabalho, são aquelas que se manifestam na informalidade, em geral, nos pequenos atos e palavras que, se reiterados no tempo, podem dar corpo ao assédio moral.

Segundo Heloani, o assédio moral (também conhecido por mobbing, ou psicoterror) consiste "na constante e deliberada desqualificação da vítima, seguida de sua consequente fragilização, com o intuito de neutralizá-la em termos de poder"262. Essa série de condutas, tanto omissivas quanto comissivas, são, de início, aparentemente inofensivas, mas sua repetição e intensificação paulatina abalam o psicológico do sujeito assediado, despersonalizando-o e anulando sua vontade ${ }^{263}$. Essa manipulação perversa se caracteriza pela regularidade das agressões e pela persistência do agressor em "desestabilizar emocionalmente a vítima para obrigá-la a se afastar do trabalho"264.

O assédio moral comporta práticas direcionadas a três esferas da vida de suas vítimas. No âmbito comunicacional, a fala dirigida ao assediado é agressiva, rude e recriminadora, ou então suas relações com os demais obreiros são cortadas e o assediado fica isolado na organização. As linhas de ação empregadas pelo agressor, noutro giro, podem ter como objetivo minar a reputação da vítima, por meio da agressão, do constrangimento, da depreciação direta ou velada, ou ainda, de críticas ao modo de ser do trabalhador e às suas características. Na terceira esfera, as condutas se prestam a desqualificar o trabalho das vítimas, atingindo sua profissionalidade (o campo da retribuição simbólica do trabalhador) — quando perpetrados por superiores, podem abranger os rebaixamentos de função, a recusa

${ }^{261}$ OIT. La igualdad en el trabajo: afrontar los retos que se plantean. Informe global con arreglo al seguimiento de la Declaración de la OIT relativa a los principios y derechos fundamentales en el trabajo. Genebra: OIT, 2007, p. 47.

262 HELOANI, Roberto. Assédio moral - um ensaio sobre a exploração da dignidade no trabalho. RAE-eletrônica, v. 3, n. 1, jan./jun. 2004. Disponível em: <http://www.scielo.br/pdf/raeel/v3n1/v3n1a12>. Acesso em 8 de março de 2016, p. 5.

${ }^{263}$ Ibid., p. 5.

${ }^{264}$ GUEDES, Márcia Novaes. Terror psicológico no trabalho. 3. ed. São Paulo: LTr, 2008, p. 37. 
em se atribuir tarefas ao assediado ou a sua designação para atividades de menor importância no contexto da organização ${ }^{265}$.

O psicoterror pode ser vertical descendente (mais comum, praticado por superior hierárquico contra empregado), horizontal (cometido entre trabalhadores), ou vertical ascendente (mais raro, parte do empregado a seu superior hierárquico) ${ }^{266}$, e é resultado da junção da ânsia de poder com a perversidade institucionalizada - que, no modelo de empresa flexível, em doses homeopáticas, torna-se trivial e admissível $^{267}$. A hipercompetitividade do mundo do trabalho contemporâneo, afinal, estimula a instrumentalização do outro ${ }^{268}$.

De toda sorte, a perpetuação do assédio moral está diretamente relacionada à maneira como o poder diretivo é exercido na organização, visto que tanto o abuso de poder quanto a inação e a complacência dos gestores com as práticas que caracterizam o assédio criam condições propícias ao surgimento do psicoterror e ao seu agravamento 269 .

Os preconceitos, a exemplo das homofobias, figuram entre as causas mais recorrentes do assédio moral, transformando as vítimas em "bodes expiatórios" da coletividade $^{270}$. De fato, os assediadores, como sinaliza Heloani, frequentemente exibem perfis que poderiam ser descritos, na terminologia de Young-Bruehl ${ }^{271}$, como "preconceituosos de viés histérico, obsessivo ou narcisista":

$\mathrm{Na}$ verdade, esses agressores possuem traços narcisistas e destrutivos, estão freqüentemente inseguros quanto à sua competência profissional e podem exibir, às vezes, fortes características de personalidade paranóica, pela qual projetam em seus semelhantes sua "sombra", ou melhor, aquilo que não conseguem aceitar em si mesmos ${ }^{272}$.

O discurso e a mentalidade viril interiorizados pelas organizações atuais são um dos motivos pelos quais muitos homens têm dificuldade até mesmo em identificar

${ }^{265}$ GUEDES, Márcia Novaes. Terror psicológico no trabalho. 3. ed. São Paulo: LTr, 2008, p. 34.

${ }^{266}$ Ibid., p. 39-42.

${ }^{267}$ HIRIGOYEN, Marie-France. El acoso moral: el maltrato psicológico en la vida cotidiana. Barcelona: Paidós, 1999, p. 43.

${ }^{268}$ HELOANI, Roberto. Assédio moral - um ensaio sobre a exploração da dignidade no trabalho. RAE-eletrônica, v. 3, n. 1, jan./jun. 2004. Disponível em: <http://www.scielo.br/pdf/raeel/v3n1/v3n1a12>. Acesso em 8 de março de 2016, p. 3.

${ }^{269}$ GUEDES, op. cit., p. 69.

270 lbid., p. 40.

271 Cf. YOUNG-BRUEHL, Elisabeth. The anatomy of prejudice. Cambridge: Harvard University Press, 1996.

${ }^{272}$ HELOANI, op. cit., p. 5. 
o assédio quando ele ocorre. Para muitos, determinadas práticas que poderiam ser caracterizadas como mobbing são vistas como meras brincadeiras ou legítimas técnicas de gestão organizacional. Essa tendência a minimizar a importância das agressões gera indisposição e relutância em prestar apoio às vítimas ${ }^{273}$.

O mobbing homofóbico pode ser perpetrado tanto individual quanto coletivamente. Nesse último caso, tende a ocorrer quando as vítimas transgredem a cultura heterossexista e as normas de virilidade que estruturam a coesão do grupo. Mas, mesmo quando parte de um único trabalhador, o mobbing pode ter a contribuição do restante do coletivo ${ }^{274}$. São os chamados espectadores, ou side-mobbers, que auxiliam diretamente o agressor em suas práticas ou, por diversas razões, nada fazem para impedi-las, mantendo-se inertes perante as agressões e o sofrimento das vítimas $^{275}$. O assediado, consequentemente, é desestimulado a reagir e a se manifestar, pois enxerga na inércia dos colegas um apoio silencioso ao comportamento do agressor (ainda que a inação dos demais seja fruto do medo ou um mecanismo de autodefesa e autopreservação) $)^{276}$.

Um tipo de conduta assediadora bastante comum no ambiente de trabalho, voltada à preservação de identidade grupal masculinizada, são os trotes — tarefas, por vezes violentas e humilhantes, como rituais de admissão e testes para a masculinidade dos novatos ${ }^{277}$.

Vale lembrar, outrossim, que o estereótipo gay é caricaturalmente engraçado, tendente a instigar o humor ${ }^{278}$. Não é a toa que uma das formas mais corriqueiras de manifestação das homofobias, nas relações de trabalho, são os discursos jocosos, travestidos de brincadeiras pretensamente inocentes relativas à orientação sexual ${ }^{279}$.

Cuida-se de um dos mecanismos que compõem o sistema de virilidade para forçar a coesão do grupo em torno de um modo de ser no trabalho, induzindo cada obreiro a adequar seu comportamento e sua postura. Homens abertamente gays ou

\footnotetext{
${ }^{273}$ MCGINLEY, Ann C. Creating masculine identities: bullying and harassment "because of sex". University of Colorado Law Review, v. 79, 2008, p. 1179.

${ }^{274}$ Ibid., p. 1172.

${ }^{275}$ GUEDES, Márcia Novaes. Terror psicológico no trabalho. 3. ed. São Paulo: LTr, 2008, p. 69.

${ }^{276}$ MCGINLEY, op. cit., p. 1172.

277 Ibid., p. 1184.

${ }^{278}$ IRIGARAY, Hélio Arthur Reis; SARAIVA, Luiz Alex Silva; CARRIERI, Alexandre de Pádua. Humor e discriminação por orientação sexual no ambiente organizacional. Revista de administração contemporânea, v.14, n.5, p. 890-906, Set./Out. 2010, p. 892.

${ }^{279}$ Ibid., p. 898.
} 
que sejam vistos pelos demais trabalhadores como afeminados, na concepção binária de gênero, são os alvos mais frequentes desse tipo de assédio ${ }^{280}$.

Pelo humor, veladamente indicando que homossexuais não são sérios nem dignos de respeito ou consideração, se desqualifica e se subordina o trabalhador gay, limitando sua participação na organização e suas perspectivas profissionais. Homossexuais são apenas tolerados, por serem vistos como divertidos, frívolos e descompromissados, em contraposição aos homens heterossexuais, que seriam vistos como trabalhadores verdadeiramente sérios e focados ${ }^{281}$.

Essa violência moral de viés homofóbico, aliás, assume, principalmente, a forma verbal. Contudo, por se tratar de uma agressão que, em grande medida, não deixa rastros visíveis e nem se materializa em documentos, as vítimas encontram grandes dificuldades para comprová-la ${ }^{282}$.

Vale atentar, finalmente, para o fato de que os trabalhadores homossexuais que sofrem com a violência moral no contexto organizacional não estão imunes à reprodução dos preconceitos de que são vítimas. Esses mesmos atores eventualmente também discriminam colegas gays que exibam trejeitos, maneirismos ou comportamentos culturalmente reputados femininos - o que revela uma dificuldade do próprio segmento em lidar com a sua diversidade interna ${ }^{283}$.

Mais do que uma estratégia adotada por alguns obreiros gays, no âmbito do trabalho, para, desviando o foco, manter o segredo quanto à própria orientação sexual, a discriminação cometida por homossexuais contra outros homossexuais, notadamente aqueles que performam o estereótipo considerado "afeminado", é sintomática da desigualdade de poder existente também entre homens gays. Há, portanto, uma hierarquia entre gays, nos moldes da concepção binária de gênero, na

\footnotetext{
${ }^{280}$ MCGINLEY, Ann C. Creating masculine identities: bullying and harassment "because of sex". University of Colorado Law Review, v. 79, 2008, p. 1186-1187.

${ }^{281}$ IRIGARAY, Hélio Arthur Reis; SARAIVA, Luiz Alex Silva; CARRIERI, Alexandre de Pádua. Humor e discriminação por orientação sexual no ambiente organizacional. Revista de administração contemporânea, v.14, n.5, p. 890-906, Set./Out. 2010, p. 897.

${ }^{282}$ SOUZA JÚNIOR, Armando Araújo de; et al. Aspectos da dominação masculina no assédio moral ao profissional homossexual no polo industrial de Manaus. Revista Pensamento \& Realidade, v. 28, n. 1, p. 83-102, 2013, p. 98.

${ }^{283}$ SIQUEIRA, Marcus Vinícius et al. Homofobia e violência moral no trabalho no Distrito Federal. Revista Organizações \& Sociedade, v. 16, n. 50, p. 447-461, jul./set. 2009, p. 454455.
} 
qual, embora sejam ambas estigmatizadas, as expressões viris da homossexualidade tendem a ser mais aceitas do que suas formas feminizadas ${ }^{284}$.

Recorrentes, encobertas ou até mesmo escancaradas, as práticas discriminatórias contra trabalhadores homossexuais são parte do dia a dia das organizações empresariais, em graus diferenciados. Cumpre ver, então, os reflexos dessa realidade na subjetividade e na formação identitária desses trabalhadores, investigando igualmente as estratégias adotadas pelos obreiros gays para lidar com a discriminação que podem enfrentar na dinâmica das relações de emprego.

\subsubsection{Homossexualidade e estigma: 0 trabalhador gay na luta pela autopreservação}

Segundo Gaulejac, identidade é uma "noção complexa, eminentemente psicossociológica. Ela evoca uma permanência no tempo de indivíduos que se transformam incessantemente para tentar controlar o curso de suas existências"285. Cuida-se, portanto, de um conjunto variável de elementos que permitem a cada um reconhecer-se e ser reconhecido como si mesmo, uma unidade que se prolonga temporalmente, a despeito de todas as mudanças a que está sujeita ao longo da vida.

O autor explica que a construção identitária não é linear, mas se dá mediante um processo dialético, que nos confere um sentimento de coerência, conquanto envolva, simultânea e contraditoriamente, as ideias de similitude e diferenciação. $O$ indivíduo se define tanto pelo conjunto de características que compartilha com os outros quanto pelo que lhe é particular, permitindo distingui-lo, em sua singularidade, de seus semelhantes. A identidade resulta, portanto, da conjugação dinâmica de uma parte nuclear da psique, com o contexto social no qual o sujeito se insere - é dizer, desejos e projeções mesclados aos costumes, normas e códigos que o meio (re)produz como forma de reconhecer seus membros ${ }^{286}$.

284 SOUZA, Eloisio Moulin de; PEREIRA, Severino Joaquim Nunes. (Re)produção do heterossexismo e da heteronormatividade nas relações de trabalho: a discriminação de homossexuais por homossexuais. Revista de Administração Mackenzie - RAM, v. 14, n. 4, p. 76-105, jul./ago. 2013, p. 98-99.

${ }^{285}$ GAULEJAC, Vincent de. Identité. In: Barus-Michel, J.; Enriquez, E.; Lévy, A (coord.). Vocabulaire de psychosociologie: références et positions. Paris: Érès, 2002, p. 174, tradução livre, no original: "Notion complexe, éminemment psychosociologique, elle évoque la permanence dans le temps d'individus qui ne cessent de se transformer pour tenter de maîtriser le cours de leur existence".

${ }^{286}$ Ibid., p. 175-176. 
Nesse rumo, uma parte central da formação identitária, enfatizam Stets e Burke, repousa na capacidade reflexiva do eu de se tomar por objeto e se classificar em relação às categorias sociais conhecidas, compreendendo-se como pertencente a determinados grupos e diferente, portanto, daqueles que não os integram ${ }^{287}$. É dizer, a identidade de uma pessoa é moldada em relação aos outros e nas relações que se trava com os outros.

Os processos de construção da identidade também variam ao longo da história. Ao contrário da sociedade medieval, em que as funções sociais (e, bem assim, a identidade) eram, em grande medida, predeterminadas pelo estamento a que se pertencia, na pós-modernidade o protagonismo é do indivíduo livre e independente: as pessoas se tornam responsáveis por atribuir sentido à sua própria existência. Em um cenário de posições sociais instáveis, cada um tem de construir a sua própria identidade e encontrar as formas para se autorrealizar ${ }^{288}$. Como assevera Gaulejac:

A partir do momento em que o lugar de todos não está atribuído a priori, cada indivíduo tem, certamente, a liberdade para mudar de lugar, mas também corre o risco de perdê-lo. Por conseguinte, as tensões aumentam entre a identidade herdada, que vem do nascimento e das origens sociais; a identidade adquirida, fortemente ligada à posição sócio-profissional; e a identidade esperada, na qual as pessoas aspiram ser reconhecidas ${ }^{289}$.

Para a sociedade capitalista, a identidade é também um recurso e assume a natureza de um empreendimento pessoal. A afirmação de si mesmo, a aquisição e a manutenção de posições sociais de prestígio são investimentos indispensáveis à integração social ${ }^{290}$.

No curso desse processo pessoal de se (re)construir incessantemente, o trabalho é um fim e também um meio em si mesmo: um âmbito da vida social necessário não somente à sobrevivência, mas também à conquista de determinados padrões de vida, à estruturação da autoimagem e às relações de reconhecimento. É principalmente pelo trabalho que, na vida adulta, a identidade das pessoas se

\footnotetext{
287 STETS, Jan E.; BURKE, Peter J. Identity theory and social identity theory. Social psychology quarter, v. 2000, n. 3, p. 224-237, 2000, p. 225.

${ }^{288}$ GAULEJAC, Vincent. Identité. In: Barus-Michel, J.; Enriquez, E.; Lévy, A (coord.). Vocabulaire de psychosociologie: références et positions. Paris: Érès, 2002, p. 177.

${ }^{289}$ Ibid., p. 177.

290 Ibid., p. 179.
} 
constitui. O sujeito é delineado pelo onde, como e com o quê trabalha, bem como pelos valores e princípios promovidos pela organização na qual se insere ${ }^{291}$.

Como conclui Gini: "Descartes estava errado. Não é Cogito ergo sum, mas sim Laboro ergo sum. Nós precisamos do trabalho e, como adultos, nos identificamos e somos identificados pelo trabalho que fazemos" 292 .

Paixão e Lourenço lembram ainda que, no modelo tradicional de relação de emprego, a "ideia de permanência na empresa, a reiteração do local de trabalho, os turnos e jornadas previstas e com padrões de repetição, tudo isso possibilitava algum tipo de orientação do trabalhador no tempo e no espaço" ${ }^{293}$, que são as "dimensões constitutivas da experiência humana no mundo exterior"294.

A despeito dessa importância do trabalho para a subjetividade, já se assinalou que, na condição de fator que incita a marginalização, a violência, a exclusão e a precarização no contexto laboral, o heterossexismo e as homofobias restringem o espectro de possibilidades profissionais dos homossexuais, Ihes impingem barreiras adicionais para que alcancem posições estáveis ou de maior prestígio e erigem obstáculos a que sejam reconhecidos por sua contribuição para a organização empresarial. Se o trabalho, em sua concepção moderna, emerge como valor fundamental para a vida do cidadão, excluir homossexuais do mundo do trabalho implica despojá-los de sua cidadania e, mais ainda, de sua condição humana:

Em nosso tempo, quando se impede que as pessoas trabalhem em
razão de sua orientação sexual estamos diante de outra condenação,
aquela que remete à morte, pois após a modernidade só o trabalho
insere o sujeito na vida (digna) em sociedade. Por mais criticável que
possa ser a imposição do trabalho livre (triste paradoxo), e mesmo
considerando todos os avanços do Estado Social (Castel, 1998) e
seus suportes sociais para a existência (por sua vez também
associados à capacidade para o trabalho e pensado a partir da
unidade familiar), é ainda o trabalho que nos possibilita viver. Estamos
aí colocados na trama do humano, impedir o trabalho é impedir de
"ser" humano. Trata-se do lugar onde se pode "cortar o mal pela raiz".
Se a sexualidade não pode ser exercida fora dos limites impostos pela

${ }^{291}$ GINI, Al. Work, identity and self: how we are formed by the work we do. Journal of the business ethics, v. 17, p. 707-714, 1998, p. 708.

${ }^{292}$ Ibid., p. 714, tradução livre, no original: "Descartes was wrong. It isn't Cogito ergo sum, but rather Laboro ergo sum. We need work, and as adults we find identity in and are identified by the work we do".

${ }^{293}$ LOURENÇO FILHO, Ricardo; PAIXÃO, Cristiano. Impactos da terceirização no mundo do trabalho: tempo, espaço e subjetividade. Revista do Tribunal Superior do Trabalho, Brasília, v. 80, n. 3, jul./set. 2014, p. 61,

${ }^{294}$ Ibid., p. 66, 
norma, é pela transformação do trabalho em suplício que se pode extinguir a vida ${ }^{295}$.

Vê-se, portanto, que a homossexualidade se apresenta socialmente como uma característica com potencial para tornar o indivíduo um ser de menor valor, quando comparado àqueles que se enquadram na heterossexualidade - fato este que impacta praticamente todas as esferas da vida do sujeito gay. Características desse tipo constituem o que Goffman denomina estigma, um atributo culturalmente considerado depreciativo, que, ao mesmo tempo em que desvaloriza os indivíduos ao qual é relacionado, confirma a normalidade dos demais ${ }^{296}$. Há dois tipos de pessoas estigmatizadas, de acordo com o autor: portadores de estigmas podem ser sujeitos desacreditados, caso o seu "defeito" seja evidente ou perceptível de imediato; ou desacreditáveis, caso o atributo depreciativo for passível de ocultação - a exemplo da orientação sexual.

A vida social, decerto, depende da estruturação e da incorporação de um conjunto de expectativas normativas e de categorias compartilhadas que oriente a interação humana. Assim, entre parceiros de interação que não se conhecem, essas preconcepções são inconscientemente invocadas, gerando expectativas normativas de uns para com os outros - expectativas que podem ou não corresponder à realidade, mas que são rompidas quando o estigma transparece. Isso porque o estigma têm aptidão para excluir o indivíduo das categorias socialmente consideradas normais e até mesmo propriamente humanas ${ }^{297}$.

Nesse sentido, Butler assevera que:

Sujeitos são constituídos através de normas que, em sua reiteração, produzem e alteram os termos pelos quais são reconhecidos. Essas condições normativas para a produção do sujeito geram uma ontologia historicamente contingente, de tal forma que nossa própria capacidade para discernir e nomear o "ser" do sujeito depende das normas que viabilizam esse reconhecimento. (...) Há sujeitos que não são efetivamente reconhecidos como sujeitos, e há "vidas" que não são frequentemente - ou, melhor, nunca são - reconhecidas como vidas $^{298}$.

${ }^{295}$ NARDI, Henrique Caetano. Nas tramas do humano: quando a sexualidade interdita o trabalho. In: POCAHY, Fernando (org.). Rompendo o silêncio: homofobia e heterossexismo na sociedade contemporânea. Porto Alegre: Nuances, 2007, p. 72.

${ }^{296}$ GOFFMAN, Erving. Estigma: notas sobre a manipulação da identidade deteriorada. 4. Ed. Rio de Janeiro: LTC, 1988, p. 13.

${ }^{297}$ Ibid., p. 11-13.

${ }^{298}$ BUTLER, Judith. Frames of war: when is life grievable? London: Verso, 2009, p. 3-4, tradução livre, no original: "Subjects are constituted through norms which, in their reiteration, produce and shift the terms through which subjects are recognized. These normative 
Esse aparato de categorias, pressupostos e normas culturais atua indistintamente sobre estigmatizados e não estigmatizados. Uma vez que, desde a infância, o processo de socialização reproduz para todos os integrantes de uma sociedade, os mesmos valores e expectativas normativas daquela cultura, os indivíduos portadores de atributos socialmente depreciados são reiteradamente expostos às crenças sociais sobre a normalidade e o desvio, o certo e o errado, 0 adequado e o inadequado. Ao incorporar os padrões da ordem social, no entanto, o indivíduo estigmatizado fica propenso a identificar em si a mácula imputada aos portadores daquele atributo e, bem assim, a se reconhecer na condição de um ser aquém do ideal ${ }^{299}$.

Nesse sentido, indivíduos marcados por um mesmo estigma compartilham uma "carreira moral", ${ }^{300}$ que perpassa a incorporação, pelo sujeito, da perspectiva social dominante sobre as identidades depreciadas, seguida de uma fase de descoberta e aprendizado de sua própria condição como portador de um estigma e das consequências advindas desse status ${ }^{301}$.

A heteronormatividade ${ }^{302}$ é uma dessas chaves para a cognição humana, a partir da qual são fixados padrões de reconhecimento. Nas relações sociais, ela estrutura uma expectativa inconsciente de que todo sujeito com quem se interage será presumidamente heterossexual, até prova em contrário. A quebra desse pressuposto, seja pela revelação espontânea ou forçada da homossexualidade, seja pela mera suspeita da orientação sexual estigmatizada, gera perplexidade e dificuldade em assimilar a diferença.

O fato de a heteronormatividade, em geral, ainda fazer parte do processo de socialização na cultura ocidental, traz consequências à formação da personalidade dos homossexuais, na forma de uma violência simbólica usualmente denominada

\footnotetext{
conditions for the production of the subject produce an historically contingent ontology, such that our very capacity to discern and name the "being" of the subject is dependent on norms that facilitate that recognition. [...] there are 'subjects', who are not quite recognizable as subjects, and there are 'lives', that are not quite - or, indeed, are never-recognized as lives". ${ }^{299}$ GOFFMAN, Erving. Estigma: notas sobre a manipulação da identidade deteriorada. 4. Ed. Rio de Janeiro: LTC, 1988, p. 17.

${ }^{300}$ Goffman define carreira moral como uma sequência de mudanças que a trajetória individual "provoca no eu da pessoa e em seu esquema de imagens para julgar a si mesma e aos outros" (Id., Manicômios, prisões e conventos. São Paulo: Perspectiva, 1987, p. 112).

${ }^{301}$ Id., op. cit., 1988, p. 41.

${ }^{302}$ Isto é, a afirmação cultural da heterossexualidade enquanto padrão de normalidade humano.
} 
homofobia interiorizada. Indivíduos gays, na construção de sua subjetividade, absorvem os padrões cognitivos de estigmatização da homossexualidade e, ao se perceberem também homossexuais, se inclinam a desenvolver um repúdio a si mesmos, desencadeando uma batalha contra a aceitação de seus desejos ${ }^{303}$.

A interiorização do estigma é o que faz com que homossexuais possam experimentar o sentimento de vergonha pelo que são ${ }^{304}$, um sofrimento social e psíquico decorrente da perturbação identitária gerada pela humilhação de ser apontado como alguém diferente, inadequado e/ou imperfeito. Assimilar que sua existência pertence a um estrato inferior da hierarquia sexual confere, ao olhar dos outros sobre o sujeito, uma primazia em relação ao olhar que tem de si mesmo para valorar e avaliar a própria vida ${ }^{305}$.

Os desdobramentos da ferida narcísica relacionada à vergonha de ser homossexual variam. Em havendo condições pessoais e no próprio ambiente, a vergonha pode desencadear no indivíduo um ímpeto de reação, com vistas a recuperar a imagem e a dignidade violadas. Se as circunstâncias não o permitirem, porém, esse sentimento pode se instalar e gerar inibição, transformando a estima em desamor e perdurando mesmo depois de cessadas as violências que the deram causa $^{306}$.

Em termos de inserção e permanência no mercado de trabalho, é crucial atentar para o fato de que homossexuais, enquanto categoria estigmatizada, se definem por um atributo não cognoscível de imediato. São, portanto, indivíduos desacreditáveis, que em cada uma de suas interações sociais lidam com a incerteza sobre o grau de informação a respeito de seu estigma que podem fazer conhecer, de modo a evitar reações hostis:

A questão que se coloca não é a da manipulação da tensão gerada durante os contatos sociais e, sim, da manipulação de informação sobre o seu defeito. Exibi-lo ou ocultá-lo; contá-lo ou não contá-lo; revelá-lo ou escondê-lo; mentir ou não mentir; e, em cada caso, para quem, como, quando e onde ${ }^{307}$.

${ }^{303}$ BORRILLO, Daniel. Homofobia: história e crítica de um preconceito. Belo Horizonte: Autêntica Editora, 2010, p. 101.

${ }^{304}$ GOFFMAN, Erving. Estigma: notas sobre a manipulação da identidade deteriorada. 4. Ed. Rio de Janeiro: LTC, 1988, p. 17.

${ }^{305}$ GAULEJAC, Vincent. As origens da vergonha. São Paulo: Via Lettera Editora e Livraria, 2006 , p. 67.

${ }^{306}$ Ibid., p. 59-60.

307 GOFFMAN, op. cit., p. 51. 
Segundo Sedgwick, em vista da comoção ainda gerada sempre que o véu do segredo é levantado (para o próprio homossexual e para os outros), a metáfora do armário permanece central na estruturação da subjetividade de todo indivíduo gay, mesmo daqueles amplamente assumidos, pois toda interação traz um risco a ser mensurado quanto à possibilidade de rejeição, por causa da identidade sexual revelada:

Cada encontro com uma nova turma de estudantes, para não falar de um novo chefe, assistente social, gerente de banco, senhorio, médico, constrói novos armários cujas leis características de ótica e física exigem, pelo menos da parte de pessoas gays, novos levantamentos, novos cálculos, novos esquemas e demandas de sigilo ou exposição. Mesmo uma pessoa gay assumida lida diariamente com interlocutores que ela não sabe se sabem ou não. É igualmente difícil adivinhar, no caso de cada interlocutor, se, sabendo, considerariam a informação importante. No nível mais básico, tampouco é inexplicável que alguém que queira um emprego, a guarda dos filhos ou direitos de visita, proteção contra violência, contra "terapia", contra estereótipos distorcidos, contra o escrutínio insultuoso, contra a interpretação forçada de seu produto corporal, possa escolher deliberadamente entre ficar ou voltar para o armário em algum ou em todos os segmentos de sua vida. O armário gay não é uma característica apenas das vidas de pessoas gays. Mas, para muitas delas, ainda é a característica fundamental da vida social, e há poucas pessoas gays, por mais corajosas e sinceras que sejam de hábito, por mais afortunadas pelo apoio de suas comunidades imediatas, em cujas vidas o armário não seja ainda uma presença formadora ${ }^{308}$.

Essa insegurança quanto à conveniência da revelação ou não da homossexualidade, em função de possíveis reflexos para o sujeito ou para sua carreira, se abate sobre os trabalhadores gays qualquer que seja a sua colocação na hierarquia organizacional. Evidência nesse sentido é o relato de John Browne, exCEO da British Petroleum (BP) entre os anos de 1995-2007, que, após mais de quarenta anos, abandonou a empresa na qual havia trabalhado a maior parte de sua vida, em meio a escândalos na mídia acerca de sua sexualidade ${ }^{309}$.

A respeito das dificuldades envolvidas na administração rotineira de uma identidade estigmatizada no ambiente corporativo, medindo gestos e palavras, Browne assevera que:

Fazer esses tipos de cálculos diariamente é desgastante, especialmente quando a jornada de trabalho, por vezes, se estende por até dezesseis horas. É também desgastante ter de ocultar detalhes do que você fez no fim de semana, mudando o pronome

\footnotetext{
${ }^{308}$ SEDGWICK, Eve Kosofsky. A epistemologia do armário. Cadernos Pagu, n. 28, p. 19-54, jan./jun. 2007, p. 22.

${ }^{309}$ Cf. BROWNE, John. The glass closet: why coming out is good business. WH Allen, 2014.
} 
usado para se referir à pessoa que você está namorando e se assegurar de que você não esteja acidentalmente revelando aspectos da sua vida na mídia social ${ }^{310}$.

Trabalhadores homossexuais transitam num campo de incertezas a respeito do quanto seus colegas e superiores sabem sobre sua identidade sexual e do quanto poderiam ou deveriam saber. Há um fundado receio de que indícios da homossexualidade sejam inconsciente e implicitamente transmitidos em suas relações, colocando-os numa posição de vulnerabilidade e de submissão perante aqueles que potencialmente têm ciência do segredo a seu respeito que não poderia ser levado a público ${ }^{311}$. No ambiente de trabalho contemporâneo de alta competitividade e falta de empatia e solidariedade, a instrumentalização dessa informação como forma de subjugar, chantagear ou assediar o trabalhador gay tornase uma possibilidade bastante concreta, como se frisou no tópico anterior.

Nesse sentido, a reprodução, nas organizações, de uma cultura hostil à homossexualidade exige dos homossexuais a adoção de um conjunto de posturas e precauções voltadas à autopreservação pessoal e profissional ${ }^{312}$.

Esses "cursos de ação ou linhas-mestras, sejam gerais ou específicos, conscientemente concebidos" ${ }^{\prime 313}$ de que os homossexuais se valem para lidar com uma situação que Ihes é potencialmente desfavorável constituem estratégias para assegurar a sua sobrevivência no trabalho. Quando bem sucedidas, instigam outros homossexuais a adotarem posturas semelhantes, reproduzidas por mimetismo ${ }^{314}$.

Irigaray divisa três categorias de trabalhadores gays no âmbito das organizações, com base no grau de exposição de sua identidade sexual — cada uma

${ }^{310}$ BROWNE, John. The glass closet: why coming out is good business. WH Allen, 2014, p. 65, tradução livre, no original: "Making those kinds of calculations on a daily basis is exhausting, especially when the working day sometimes stretches to sixteen hours. So too is having to obscure details of what you did over the weekend, changing the pronoun used to refer to the person you are dating and making sure you do not accidentally reveal aspects of your life on social media".

${ }^{311}$ SEDGWICK, Eve Kosofsky. A epistemologia do armário. Cadernos Pagu, n. 28, p. 19-54, jan./jun. 2007, p. 38.

312 IRIGARAY, Hélio Arthur. Estratégias de sobrevivência dos gays no ambiente de trabalho. Anais do XXXI Encontro Anual da Associação Nacional de Pós-Graduação e Pesquisa em Administração - EnANPAD, Rio de Janeiro, 2007, 31, p. 5.

${ }^{313}$ É nesses termos que Costa e Silva conceituam estratégia (COSTA, Lenise Saraiva de Vasconcelos; SILVA, Jorge Ferreira da. As tipologias estratégicas "realmente" existem? Anais do XXVI Encontro Anual da Associação Nacional de Pós-Graduação e Pesquisa em Administração - EnANPAD. Salvador, 2002).

${ }^{314}$ IRIGARAY, op. cit., p. 5. 
adotando modalidades particulares de estratégias de sobrevivência, com suas pertinentes repercussões sobre a subjetividade e a saúde do obreiro ${ }^{315}$.

A primeira categoria, constituída por trabalhadores totalmente assumidos, posiciona-se de forma transparente sobre a homossexualidade em qualquer espaço social. Passando da condição de desacreditáveis a de desacreditados, a preocupação com a administração de informações sobre o estigma cede lugar à busca de aceitação no convívio com os não estigmatizados ${ }^{316}$. Por conseguinte, esse grupo costuma pender para dois tipos de estratégia. Seus integrantes, de um lado, atuam como gladiadores no meio corporativo, assumindo uma postura combativa em face da discriminação e lutando ativamente por seus direitos. De outro lado, podem incorporar a posição de pacificadores, esforçando-se para agir com simpatia e cordialidade, ou se mostrando sempre solícitos e cooperativos, como forma de evitar a erupção ou o agravamento de conflitos em decorrência de sua orientação sexual ${ }^{317}$.

A segunda categoria é composta por trabalhadores parcialmente assumidos (sejam eles heterossexuais organizacionais, que ocultam sua orientação sexual apenas e tão somente no ambiente de trabalho, ou heterossexuais funcionais, que a expõem exclusivamente a um número muito restrito de pessoas da sua confiança). Para esse grupo, uma das estratégias comuns é se fazer passar por gente boa, comportar-se de maneira bem-humorada e disponível, como forma de chamar atenção para esses traços de personalidade, desviando o foco da orientação sexual, para que não seja revelada. Alternativamente, podem adotar o perfil do super homem, evitando a descoberta do segredo ao desviar o foco para o seu engajamento no trabalho e por sua eficiência - acentuam, portanto, a identidade profissional para encobrir a identidade sexual estigmatizada ${ }^{318}$.

Já a terceira categoria é a dos trabalhadores homossexuais não assumidos que se comportam socialmente como heterossexuais, às vezes de forma até exagerada, evitando associações de sua imagem à homossexualidade. Parte desses indivíduos mantém essa fachada pela adoção do estereótipo do machão: performam

\footnotetext{
${ }^{315}$ IRIGARAY, Hélio Arthur. Estratégias de sobrevivência dos gays no ambiente de trabalho. Anais do XXXI Encontro Anual da Associação Nacional de Pós-Graduação e Pesquisa em Administração - EnANPAD, Rio de Janeiro, 2007, 31, p. 7.

${ }_{316}$ KAUFMAN, Joanne K.; JOHNSON, Cathryn. Stigmatized individuals and the process of identity. The Sociological Quarterly, v. 45, n. 4, p. 807-833, 2004, p. 825.

${ }^{317}$ IRIGARAY, op. cit., p. 8-9.

${ }^{318}$ Ibid., p. 8-9.
} 
uma masculinidade acentuadamente viril e, não raro, explicitamente homofóbica, a fim de calar qualquer dúvida sobre sua sexualidade. Outros tantos encarnam o papel do sedutor, emulando uma heterossexualidade por meio das investidas constantes ao sexo oposto ou pela afirmação pública de suas conquistas amorosas e sexuais. Um terceiro subgrupo, porém, ao invés de tentar emplacar uma imagem heterossexual, se amolda à estratégia do homem invisível: com uma postura contida e tímida, quase imperceptível, fazem o máximo para não serem notados no ambiente organizacional, perdidos em meio à massa de trabalhadores, não se destacando pelo bom nem pelo mau desempenho ${ }^{319}$.

Irigaray ressalta, entretanto, que esses padrões de comportamento, em particular a adoção das mencionadas estratégias de sobrevivência, impõem custos psicossociais aos trabalhadores homossexuais. A título de exemplo, introjetar um comportamento virilizado e homofóbico para angariar aceitação social erige uma barreira ao desenvolvimento do sentimento de empatia e de compreensão do sofrimento alheio. Quando ocultam sua orientação sexual, por outro lado, seja desviando o foco das atenções ou se invisibilizando, o fazem ao custo de elevados níveis de estresse gerado pelo estado de vigilância contínua quanto à sua identidade velada. Outros reflexos do encobrimento da homossexualidade são a baixa autoestima, sentimentos de melancolia e anulação, ou, em casos mais graves, o desenvolvimento de quadros de depressão ou de doenças psicossomáticas ${ }^{320}$.

De acordo com Waldo, o heterossexismo no ambiente de trabalho gera, nos obreiros homossexuais, entre outros efeitos, uma drástica redução em sua satisfação com o trabalho, altas taxas de abstenção, pretensão de abandono do emprego, além de níveis elevados de sofrimento psicológico ${ }^{321}$. O comprometimento da saúde desses trabalhadores pode desencadear, igualmente, uma deterioração progressiva de seus relacionamentos com os outros trabalhadores e seus superiores, bem como dos demais círculos sociais que o obreiro integra, incluindo família e amigos ${ }^{322}$.

${ }^{319}$ IRIGARAY, Hélio Arthur. Estratégias de sobrevivência dos gays no ambiente de trabalho. Anais do XXXI Encontro Anual da Associação Nacional de Pós-Graduação e Pesquisa em Administração - EnANPAD, Rio de Janeiro, 2007, 31, p. 8-10.

${ }^{320}$ Ibid., p. 10-11.

${ }^{321}$ WALDO, Craig R. Working in a minority context: a structural model of heterosexism as minority stress in workplace. Journal of counseling psychology, v. 46, n. 2, p. 218-232, 1999, p. 229.

${ }^{322}$ MCGINLEY, Ann C. Creating masculine identities: bullying and harassment "because of sex". University of Colorado Law Review, v. 79, 2008, p. 1190. 
Esse conjunto de desdobramentos negativos é consequência de um "estresse de minorias", definição de Meyer para a condição de estresse psicossocial continuamente vivenciada por membros de grupos minoritários, em decorrência do conflito, no ambiente social, com os valores dominantes de uma cultura que estigmatiza sua identidade. Esse tipo de estresse, no caso de homens gays, está particularmente relacionado a três fatores: a homofobia interiorizada, o estigma percebido (isto é, o grau de expectativa de rejeição ou discriminação) e as experiências concretas do sujeito com a discriminação. Cada um desses mecanismos estressores, segundo Meyer, provoca diferentes consequências adversas à saúde mental, entre as quais se destacam: o desenvolvimento de ideias ou comportamentos suicidas, de sentimento de culpa e de problemas sexuais ${ }^{323}$.

Quando, no entanto, o clima corporativo se revela receptivo à diversidade sexual e existem redes articuladas de proteção contra a discriminação, assumir-se no contexto do trabalho traz consigo um sentimento de alívio, dissipando a sensação de fragmentação identitária e melhorando as relações interpessoais e o desempenho profissional $^{324}$.

$\mathrm{O}$ ato de se assumir gay no âmbito da organização, consoante Bucher e Raess, está relacionado a níveis mais elevados de satisfação com o trabalho e tende, inclusive, a influir na redução da homofobia. Em cenários marcadamente homofóbicos, o silêncio acerca da homossexualidade é uma forma de opressão, mas também de autopreservação, que pode ser combatido assumindo-se uma postura de enfrentamento e revelação ou, por outro lado, de abandono do emprego e busca de ambientes de trabalho mais receptivos. Por isso, ferramentas como a criação de grupos de apoio e políticas de diversidade, dando voz e suporte aos homossexuais, mostram-se importantes mecanismos para fortalecer a autoestima desses trabalhadores, sua identidade e relações com colegas, beneficiando gays e seus empregadores, reduzindo problemas de saúde e promovendo o bem-estar no trabalho ${ }^{325}$.

${ }^{323}$ MEYER, Ilan H. Minority Stress and Mental Health in Gay Men. Journal of Health and Social Behavior, Vol. 36, No. 1, Mar. 1995, p. 38-56.

${ }^{324}$ IRIGARAY, Hélio Arthur. Estratégias de sobrevivência dos gays no ambiente de trabalho. Anais do XXXI Encontro Anual da Associação Nacional de Pós-Graduação e Pesquisa em Administração - EnANPAD, Rio de Janeiro, 2007, 31, p. 11.

${ }^{325}$ BUCHER, Thomas; RAESS, Daniel. Discrimination, coming out, and job satisfaction of gay men in Switzerland: results of a survey. In: LEE BADGETT, M. V.; FRANK, Jefferson. Sexual 
Ao que tudo indica, mudanças no sentido da dissolução de uma cultura heteronormativa no mundo do trabalho se encontram em andamento. Contam, por um lado, com o engajamento de movimentos sociais que propõem a desconstrução da imagem desviante que o senso comum mantém acerca da homossexualidade. De outro, a perspectiva de amparo jurídico aos trabalhadores homossexuais discriminados tende a retirá-los do estado de inibição que a vergonha e a humilhação engendram, encorajando-os a vocalizar suas insatisfações e a não permanecerem inertes diante de casos de discriminação. Numa terceira frente, a transformação é impulsionada também pela crescente percepção das organizações empresariais de que a manutenção de uma cultura corporativa complacente como a homofobia, ao fim e ao cabo, Ihes é também prejudicial.

\subsubsection{Homofobia organizacional: a necessidade de desconstrução de um fenômeno assentado em contradições}

A reestruturação do sistema produtivo e dos métodos de gestão do trabalho que vem se operando desde a década de 1970, como já se indicou, é reflexo do movimento de destruição criativa que impulsiona o capitalismo a contornar os períodos de crise, de modo a retomar o crescimento econômico e a acumulação em níveis ainda maiores do que os anteriores. Sem embargo, o advento da concepção de empresa enxuta, leve e maleável, bem como do trabalho flexível, a despeito dos discursos em sentido contrário, não eliminaram, na prática, a prevalência de uma cultura organizacional marcadamente heteronormativa e, por vezes, homofóbica. $\mathrm{O}$ que é mais grave, a precarização do trabalho e os valores que esse novo modelo encampa têm gerado condições propícias ao agravamento de posturas discriminatórias no mundo trabalho.

Esse quadro, no entanto, é de difícil (senão impossível) compatibilização com os próprios objetivos do sistema capitalista, na medida em que, na contramão da eficiência econômica, estimulam a expulsão de obreiros homossexuais do mercado de trabalho, independentemente de sua qualificação e potencial produtivo, ao mesmo tempo em que geram gastos públicos e privados que poderiam ser evitados.

orientation discrimination: an international perspective. New York: Routledge, 2007, p. 194205. 
No bojo de recentes iniciativas do Banco Mundial ${ }^{326}$, Lee Badgett conduziu uma pesquisa inédita ${ }^{327}$ voltada à apuração dos impactos econômicos gerados pela discriminação da população LGBT. Segundo a pesquisadora, os efeitos deletérios da expressão concreta desses preconceitos se ramificam em pelo menos quatro direções ${ }^{328}$.

Primeiramente, constata-se uma ineficiência nos investimentos em capital humano. Badgett frisa que a educação é o principal instrumento para se adquirir habilidades e conhecimentos úteis à vida profissional. Mas, visto que o estigma lançado sobre as minorias sexuais tende a expelir esses indivíduos do sistema educacional, barreiras à aquisição de capital humano lhes são diferenciadamente impostas, reduzindo as perspectivas de retorno que esses profissionais futuramente poderiam oferecer à economia. De outro lado, a disparidade salarial motivada pela homofobia implica injusta e desigual compensação pelo capital humano que trabalhadores LGBT detêm, desestimulando o aprofundamento da qualificação dessa parcela da população ${ }^{329}$.

Em segundo lugar, a homofobia induz ao subaproveitamento ou à não utilização de parte da força de trabalho e, bem assim, à redução do desempenho econômico. Há subaproveitamento quando, por conta de sua identidade sexual ou de gênero, trabalhadores LGBT são dispensados ou preteridos no processo de contratação, em favor de candidatos que se adequam ao modelo heteronormativo e que, eventualmente, são menos qualificados para as vagas em disputa. Também se mostra economicamente ineficiente o desperdício das habilidades desses obreiros, quando lhes é obstada a ascensão profissional por razões homofóbicas. Igualmente,

\footnotetext{
${ }^{326}$ O Grupo Banco Mundial é uma instituição financeira internacional formada pelo Banco Internacional para Reconstrução e Desenvolvimento (BIRD) e pela Associação Internacional de Desenvolvimento (AID), juntamente com mais outras três organizações (a Sociedade Financeira Internacional - SFI, a Agência Multilateral de Garantia de Investimentos - MIGA, e o Centro Internacional para Arbitragem de Disputas sobre Investimentos - CIADI), que atua junto a países em desenvolvimento, tendo por principais objetivos a erradicação da pobreza extrema e a redução de desigualdade, mediante o fomento ao crescimento da renda. Para maiores informações, consultar <http://www.worldbank.org/>.

${ }^{327} \mathrm{O}$ relatório elaborado como resultado dessa pesquisa tem base em dados e observações pertinentes à Índia contemporânea, mas que, em certa medida, são passíveis de aplicação a outras sociedades.

${ }^{328}$ LEE BADGETT, M. V. The economic cost of stigma and the exclusion of LGBT people: a case study of India. Washington, DC: World Bank, 2014, p. 5. Disponível em: $<$ https://openknowledge.worldbank.org/handle/10986/21515>. Acesso em 01/03/2016. ${ }^{329}$ lbid.
} 
a alocação da população LGBT em empregos precários, a disparidade salarial e a complacência com condutas discriminatórias no contexto organizacional impactam a produtividade desses trabalhadores, porquanto atingem seu senso de pertencimento e de utilidade, bem como a sua disposição para se engajar no trabalho ${ }^{330}$.

Em terceiro, pode-se apontar um decréscimo de produtividade oriundo de problemas de saúde atrelados ao preconceito homofóbico. Além de estarem sujeitos às complicações enfrentadas pelo restante da população, os trabalhadores LGBT veem seu desempenho particularmente comprometido devido à suscetibilidade a problemas de saúde adicionais, de ordem tanto física quanto psicológica, decorrentes do estigma e da discriminação a eles especificamente direcionados - entre eles, a recorrência de violências, a maior incidência de HIV, as altas taxas de suicídio e de depressão. Agravando esse quadro, a precarização da situação financeira das minorias sexuais fomentada pela homofobia restringe o acesso dessas pessoas aos serviços de saúde - e, mesmo quando logram acioná-los, gays, lésbicas, bissexuais e transgêneros frequentemente se deparam com mais um ambiente discriminatório e com profissionais pouco ou não capacitados para lidar com as necessidades desse segmento $^{331}$.

A quarta vertente destacada por Badgett diz respeito à evitabilidade de gastos com serviços sociais e de saúde para tratar dos reflexos da discriminação. Com efeito, os problemas de saúde relacionados à exclusão e ao estigma homofóbico tornam premente a alocação de recursos públicos e particulares para tratá-los. Da mesma forma, o desemprego, as baixas remunerações e as condições precárias de trabalho a que pessoas LGBT estão especialmente propensas a encarar repercutem nos custos do Estado e dos agentes privados com programas e iniciativas de combate à pobreza e incremento à renda ${ }^{332}$.

As conclusões do Banco Mundial sobre os reflexos econômicos da homofobia são ratificadas pela Organização Internacional do Trabalho, segundo a qual:

A saúde e o bem-estar dos trabalhadores LGBT que se isolam devido ao medo de discriminação podem ser afectados negativamente, reduzindo a sua produtividade no local de trabalho. As empresas que despedem trabalhadores devido à sua orientação sexual, real ou

\footnotetext{
${ }^{330}$ BADGETT, M. V. Lee. The economic cost of stigma and the exclusion of LGBT people: a case study of India. Washington, DC: World Bank, 2014, p. 25. Disponível em: $<$ https://openknowledge.worldbank.org/handle/10986/21515>. Acesso em 01/03/2016.

${ }^{331}$ lbid.

332 lbid.
} 
presumida, podem também perder competências e desperdiçar recursos no recrutamento e formação de novos trabalhadores ${ }^{333}$.

A nível coletivo, Guedes lista uma série de consequências do psicoterror organizacional, uma das formas pelas quais o heterossexismo se expressa na vida laboral:

De modo geral, verifica-se, a nível do grupo, uma redução na capacidade produtiva e na eficácia; acentuada crítica aos empregadores; elevada taxa de absenteísmo por doenças; tendência do grupo de fazer tempestades em copo d'água, transformando pequenos problemas em gigantescos conflitos; a busca de bodes expiatórios, pra mascarar reais problemas e culpados.

O aumento dos custos da empresa é determinado pelas faltas por doenças, substituições e despesas com processos judiciais. Está provado que um trabalhador submetido a violência psicológica tem um rendimento inferior a $60 \%$ em termos de produtividade e eficiência, em relação a outros trabalhadores, e o seu custo para o empregador é de $180 \%$ a mais ${ }^{334}$.

Outrossim, salientando que os indivíduos que disseminam práticas homofóbicas no contexto laboral impingem "custos afetivos, cognitivos e comportamentais não só aos gays (...), mas também a eles próprios e à organização como um todo", Irigaray acrescenta que o desconforto social e os mecanismos de defesa e repressão decorrentes da discriminação esgarçam vínculos sociais e moldam obreiros incapazes de negociar e de trabalhar em grupo ${ }^{335}$ - aspecto crucial do modelo toyotista de produção.

Nessa esteira, ainda que não se disponha, por ora, de dados suficientes para quantificar, de forma objetiva, os prejuízos advindos da manutenção de uma cultura homofóbica (inclusive e principalmente no âmbito organizacional), é inequívoca a existência de custos atrelados ao estigma e à exclusão provocados pela discriminação da população LGBT ${ }^{336}$.

Homofobia e crescimento econômico sustentável, com paridade de oportunidades e aproveitamento eficiente do capital humano, por conseguinte, são

${ }^{333}$ OIT. Igualdade no trabalho: um desafio contínuo. Relatório Global no quadro do seguimento da Declaração sobre os Princípios e Direitos Fundamentais no Trabalho. Genebra: OIT, 2011, p. 57.

${ }^{334}$ GUEDES, Márcia Novaes. Terror psicológico no trabalho. 3. ed. São Paulo: LTr, 2008, p. 109.

${ }^{335}$ IRIGARAY, Hélio Arthur. Estratégias de sobrevivência dos gays no ambiente de trabalho. Anais do XXXI Encontro Anual da Associação Nacional de Pós-Graduação e Pesquisa em Administração - EnANPAD, Rio de Janeiro, 2007, 31, p. 11

${ }^{336}$ BADGETT, M. V. Lee. The economic cost of stigma and the exclusion of LGBT people: a case study of India. Washington, DC: World Bank, 2014, p. 47. Disponível em: <https://openknowledge.worldbank.org/handle/10986/21515>. Acesso em 01/03/2016. 
fenômenos que apontam em direções opostas, sendo contraditória a persistência de um liame entre ambos, em que as organizações não apenas condescendem com a disseminação de práticas discriminatórias, mas chegam a estimulá-las em determinadas circunstâncias.

Como bem assinala Fraser, embora a homofobia e o sexismo ainda repercutam na forma como o trabalho e a produção se organizam, o capitalismo contemporâneo prescinde do heterossexismo para existir e se perpetuar. $O$ aprofundamento das lutas e das conquistas do movimento LGBT nos últimos anos, com um crescimento paulatino da integração e do reconhecimento, no mundo do trabalho, de pessoas não conformadas à heteronormatividade, vêm demonstrando empiricamente não representar ameaça aos alicerces do sistema produtivo capitalista $^{337}$.

O heterossexismo e a homofobia não são, afinal, questões de natureza intrinsecamente econômica, mas sim problemas atrelados às anomalias e às assimetrias nas relações de reconhecimento. Isso não torna seus efeitos, porém, menos concretos ou substanciais às organizações empresariais e, principalmente, às vítimas de discriminação. A inferiorização, a exclusão e a marginalização de pessoas com base na orientação sexual conhecida ou presumida, como já frisado, podem implicar danos bastante palpáveis. É essa a essência da negativa de reconhecimento, segundo Fraser: "a construção material, através da institucionalização de normas culturais, de uma classe de pessoas desvalorizadas às quais se impede a participação paritária"338.

Em assim sendo, a desconstrução de uma cultura heternormativa que sustenta e se alimenta da homofobia para se reproduzir, assim como a promoção de políticas de valorização da diversidade, mostram-se, na verdade, vias profícuas tanto à sociedade em geral e, particularmente, aos homossexuais, engendrando e fortalecendo laços de reconhecimento, solidariedade e respeito; quanto às organizações e ao Estado, em termos de eficiência econômica, ganhos de produtividade e gestão de recursos.

\footnotetext{
${ }^{337}$ FRASER, Nancy. Heterosexism, Misrecognition, and Capitalism: A Response to Judith Butler. Social Text, n. 52/53, 1997. p. 285.

${ }^{338}$ Ibid., p. 282-283, tradução livre, no original: “(...) the material construction through the institutionalization of cultural norms of a class of devalued persons who are impeded from participatory parity".
} 
A invisibilidade das contradições que subjazem à homofobia organizacional vai se dissipando à medida que se constatam as vantagens de um ambiente de trabalho e de uma cultura empresarial abertos à pluralidade e efetivamente responsivos à discriminação. Observa-se atualmente um processo de transição na postura assumida pelo Estado, por organizações internacionais e também por empresas (sobretudo as grandes multinacionais) em face da homofobia no contexto laboral $^{339}$.

O trabalho é um fator importante para a saúde psíquica das pessoas, desde que se desenvolva sob uma lógica de reconhecimento e de não violência, de forma a possibilitar a sua conversão em experiências de prazer e diminuir o sofrimento individual e coletivo ${ }^{340}$. Nesse rumo, figurando as homofobias como uma das feições que a violência assume no âmbito laboral e o heterossexismo como um entrave cultural ao desenvolvimento de relações de reconhecimento, é essencial repensá-los com vistas à construção de um ambiente de trabalho mais seguro e inclusivo.

É com essa preocupação que a Organização das Nações Unidas, em ação conjunta com representantes de empregadores, empregados, governos, sindicatos e movimentos sociais, vem se dedicando à elaboração de estudos e materiais que sirvam de subsídio à implantação de políticas de promoção da igualdade no trabalho, através do combate à homo-lesbo-transfobia ${ }^{341}$.

Sem embargo, é importante anotar que a introdução, nesse contexto, de temas como alteridade, apreço e respeito pela diversidade tende a encontrar resistência, por expor as inconsistências dos modelos de gestão correntes. Essas propostas esbarram na pretensão (nem sempre dissimulada) de homogeneização dos trabalhadores, através de mecanismos que os induzem à identificação com a própria organização, minando a resistência individual e coletiva à exploração do trabalho, a partir da construção de laços em torno de uma identidade compartilhada. Ou seja, tenta-se incutir a pluralidade como valor em um cenário que se mostra, em geral,

${ }^{339}$ FRASER, Nancy. Heterosexism, Misrecognition, and Capitalism: A Response to Judith Butler. Social Text, n. 52/53, 1997. p. 285.

${ }^{340}$ SIQUEIRA, Marcus Vinícius; ANDRADE, Augusto. Em busca de uma pedagogia gay no ambiente de trabalho. In: FREITAS, Maria Ester; DANTAS, Marcelo (orgs.). Diversidade sexual e trabalho. São Paulo: Cengage Learning, 2012, p. 101-102.

${ }_{341}$ Para maiores informações a respeito dessa iniciativa, cf. OIT; UNAIDS; PNUD. Promoção dos Direitos Humanos de pessoas LGBT no Mundo do Trabalho: construindo a igualdade de oportunidades no mundo do trabalho: combatendo a homo-lesbo-transfobia. 2a. ed. Brasilia, 2015. Disponível em: <http://www.ilo.org/brasilia/publicacoes/WCMS_312569/lang-pt/index.htm> Acesso em 03/02/2016. 
avesso à manifestação de diferenças culturais, sexuais, religiosas ou étnicas. A única diversidade que, em princípio, desperta o interesse das empresas é a que contribui para a eficiência e o crescimento do empreendimento ${ }^{342}$.

As medidas a serem implementadas, portanto, têm de mirar, em um plano, a reformulação de tendências e discursos organizacionais homogeneizantes e, em outro, a transformação de contextos de alta competitividade e animosidades, permeadas de pulsões destrutivas e segregativas ${ }^{343}$.

Remodelar as normas de convivência e o olhar do outro para a diferença, notadamente para as variações da sexualidade humana, é um dos passos essenciais na quebra dos obstáculos à construção de uma cultura verdadeiramente inclusiva, aberta ao reconhecimento do igual valor de cada trabalhador, com as diferenças que Ihe caracterizam, e à liberdade para expressar seu verdadeiro eu sem constrangimentos ou retaliações ${ }^{344}$.

A implantação meramente cosmética ou pontual de medidas voltadas à diversidade é, porém, incapaz de promover efetiva inclusão. O medo dos trabalhadores gays quanto à revelação de sua orientação sexual subsiste, afinal, em organizações que contam apenas formalmente com políticas inclusivas ou naquelas em que, apesar de haver igualdade na concessão de benefícios, se fazem ausentes mecanismos de proteção contra atos discriminatórios ${ }^{345}$. Sem uma rede de apoio substancial e diante da omissão dos superiores em face da homofobia, essas pessoas, administrando uma identidade sexual estigmatizada, permanecem no impasse representado por dois caminhos potencialmente prejudiciais à subjetividade e às perspectivas profissionais: sair do armário ou seguir ocultando a homossexualidade ${ }^{346}$.

A construção efetiva de um clima organizacional de acolhimento e respeito à diferença é, desse modo, decisivo para que o indivíduo se sinta confortável e seguro

${ }^{342}$ SIQUEIRA, Marcus Vinícius; ANDRADE, Augusto. Em busca de uma pedagogia gay no ambiente de trabalho. In: FREITAS, Maria Ester; DANTAS, Marcelo (orgs.). Diversidade sexual e trabalho. São Paulo: Cengage Learning, 2012, p. 105.

${ }^{343}$ Ibid., p. 105-106.

${ }^{344}$ BELL, Myrtle P. et al. Voice, silence, and diversity in $21^{\text {st }}$ century organizations: strategies for inclusion of, gay, lesbian, bisexual, and transgender employees. Human resource management, v. 50, n. 1, p. 131-146, jan./fev. 2011, p. 136.

345 SIQUEIRA, Marcus Vinícius et al. Homofobia e violência moral no trabalho no Distrito Federal. Revista Organizações \& Sociedade, v. 16, n. 50, p. 447-461, jul./set. 2009, p. 450. ${ }^{346}$ SIQUEIRA; ANDRADE; op. cit., p. 104. 
para tornar pública a sua orientação sexual no ambiente de trabalho ${ }^{347}$. Somente dessa forma, o silenciamento de trabalhadores homossexuais, estimulado pela sobreposição de fatores como a invisibilidade das orientações sexuais minoritárias, a discriminação rotineira e a falta de uma estrutura jurídica de proteção ao diferente, poderá ser suplantado, cedendo lugar à $v^{348}$ e à participação paritária dessas pessoas na organização:

Quebrar o ciclo de invisibilidade e silêncio, abrindo espaço para que empregados GLBT possam fazer contribuições positivas ao trabalho, sem receio da violência, do preconceito, da discriminação e do assédio, pode mudar o status quo ${ }^{349}$.

Em pesquisa sobre os benefícios de um ambiente de trabalho acolhedor à diversidade sexual, o Center for Talent Innovation, uma entidade sem fins lucrativos, enumera quatro providências essenciais a serem tomadas pelas organizações que pretendem firmar-se como inclusivas: a implementação igualitária de benefícios aos trabalhadores, com medidas como a inclusão de parceiros em planos de saúde ou a concessão de licenças parentalidade; a divulgação consistente de informações acerca dessas vantagens aos obreiros, de modo que eles possam tomar decisões conscientes sobre a condução de suas vidas e de suas carreiras; a construção de uma sólida cultura organizacional afeita e simpática à diversidade sexual, fazendo com que esses obreiros se sintam acolhidos e estimulados a permanecer na empresa; e a abertura à integração de trabalhadores homossexuais em cargos de nível mais

347 SIQUEIRA, Marcus Vinícius; ANDRADE, Augusto. Em busca de uma pedagogia gay no ambiente de trabalho. In: FREITAS, Maria Ester; DANTAS, Marcelo (orgs.). Diversidade sexual e trabalho. São Paulo: Cengage Learning, 2012, p. 108.

${ }^{348}$ Segundo a definição formulada por Hirschman, voz significa "toda e qualquer tentativa de mudar (em vez de escapar de) um estado desagradável de coisas, seja por meio da apresentação de demanda individual ou coletiva ao gestor diretamente responsável, por meio de recurso para uma autoridade superior, com a intenção de forçar uma mudança na gestão, ou através de vários tipos de ações e protestos, incluindo aqueles que são destinados a mobilizar a opinião pública" (HIRSCHMAN, Albert O. Exit, voice, and loyalty: responses to decline in firms, organizations, and States. Cambridge: Harvard University Press, 1970, p. 30, tradução livre, no original: "any attempt at all to change, rather than to escape from, an objectionable state of affairs, whether through individual or collective petition to the management directly in charge, through appeal to a higher authority with the intention of forcing a change in management, or through various types of actions and protests, including those that are meant to mobilize public opinion").

${ }^{349}$ BELL, Myrtle P. et al. Voice, silence, and diversity in 21st century organizations: strategies for inclusion of, gay, lesbian, bisexual, and transgender employees. Human resource management, v. 50, n. 1, p. 131-146, jan./fev. 2011, p. 139. 
elevado na hierarquia empresarial, de forma que possam servir de modelo e fonte de inspiração a seus pares ${ }^{350}$.

Para Siqueira e Andrade, a estruturação de uma pedagogia gay nas organizações requer a implementação de condições e estímulos à formação de grupos LGBT dentro das empresas, com liberdade para atuar no desmonte da homofobia internalizada e tornar seguro o clima organizacional para que os trabalhadores homossexuais se sintam dispostos a expor sua orientação sexual. Ainda nessa esteira, a desconstrução da cultura heteronormativa conta com um leque de ferramentas que podem ser introduzidas concomitante, como, por exemplo, códigos de ética, mecanismos de acolhimento de denúncias anônimas de discriminação e efetiva penalização de práticas discriminatórias ${ }^{351}$.

De toda forma, o horizonte de mudanças da opinião pública sobre a homossexualidade é quesito decisivo para estimular ou inibir a transformação da postura das empresas diante da discriminação. Seja pelo fortalecimento da pressão política oriunda dos movimentos LGBT ou pela necessidade de modernização da imagem institucional da organização, a fim de acompanhar as transformações sociais, esses fatores externos são centrais na definição da abordagem organizacional da homofobia. Não por acaso, em países como os Estados Unidos, cujos índices de aceitação da diversidade sexual vêm apresentando crescimento significativo nos últimos anos, há um maior engajamento das empresas em práticas voltadas à construção de uma cultura favorável aos trabalhadores LGBT ${ }^{352}$.

Esse quadro de transformações na postura organizacional em face da questão homossexual é retratado com um toque de humor e irreverência na comédia francesa "O closet" ("Le placard", no original), de 2001. O filme apresenta a história de François Pignon, um pacato contador divorciado que entra em desespero ao descobrir que será dispensado da empresa onde trabalha. Chegando a considerar a hipótese do suicídio, Pignon é dissuadido por seu vizinho, com quem arquiteta um plano para salvar seu emprego. Juntos constroem uma falsa identidade homossexual para o contador, por meio de montagens fotográficas remetidas anonimamente ao endereço

\footnotetext{
${ }^{350}$ HEWLETT, Sylvia Ann et al. The power of "out" 2.0: LGBT in the workplace. Nova York: Center for Talent Innovation, 2013, p. 30.

351 SIQUEIRA, Marcus Vinícius; ANDRADE, Augusto. Em busca de uma pedagogia gay no ambiente de trabalho. In: FREITAS, Maria Ester; DANTAS, Marcelo (orgs.). Diversidade sexual e trabalho. São Paulo: Cengage Learning, 2012, p. 117-118.

${ }^{352}$ Ibid., p. 107.
} 
da empresa. Esse é o gatilho para impedir a dispensa e desencadear os inusitados acontecimentos da trama: o empregador de Pignon é uma indústria que fabrica produtos de borracha, tendo na produção de preservativos a sua principal atividade e uma forte presença no mercado gay. A possibilidade de vinculação do desligamento do contador à discriminação homofóbica angustia a direção da empresa, que reconsidera sua decisão e, apenas para resguardar sua imagem, passa a encampar uma série de iniciativas e campanhas pró-homossexuais, como a participação na parada local do orgulho gay. Vale frisar, de toda sorte, a mudança meramente superficial da organização, que tem origem não em uma legítima preocupação com a promoção da diversidade sexual, mas como uma reação momentânea às possíveis consequências econômicas adversas da vinda a público de fatos que poderiam fazer transparecer a cultura empresarial anti-homossexual ${ }^{353}$.

O processo de mudança, entretanto, não é simultâneo, nem tampouco uniforme em todo o globo. O avanço dessas pautas, no âmbito organizacional, não se desvincula do contexto cultural, político e jurídico onde o empreendimento se encontra instalado. Sobre este ponto, Siqueira e Andrade ressaltam que "o desenvolvimento significativo de direitos gays nas empresas está intimamente relacionado ao ambiente, ao clima social existente no país em termos políticos, não sendo possível dissociar o organizacional do que ocorre no social”354.

No cenário brasileiro, em que é ainda largamente disseminada uma masculinidade hegemônica fortemente virilizada e homofóbica, a assimetria nas relações de poder fica evidente quanto vem à tona o tema da homossexualidade no contexto do trabalho. Essa é uma das razões pelas quais iniciativas organizacionais voltadas ao combate da homofobia e à valorização da diversidade se encontram ainda em um nível muito incipiente no país ${ }^{355}$.

Cumpre frisar, no entanto, que a existência de um aparato jurídico de enfrentamento à discriminação ${ }^{356}$, embora não seja capaz de, isoladamente, promover a completa subversão de uma socialização historicamente heteronormativa,

353 LE PLACARD. Direção: Francis Veber. Produção: Patrice Ledoux. Intérpretes: Daniel Auteuil; Gérard Depardieu; Thierry Lhermitte. Roteiro: Francis Veber. França: Miramax Films, 2001 (84min)

354 SIQUEIRA, Marcus Vinícius; ANDRADE, Augusto. Em busca de uma pedagogia gay no ambiente de trabalho. In: FREITAS, Maria Ester; DANTAS, Marcelo (orgs.). Diversidade sexual e trabalho. São Paulo: Cengage Learning, 2012, p. 107.

${ }^{355}$ Ibid., p. 112.

${ }^{356}$ Sobre o tema, consultar os Capítulos 3 e 4. 
é um fator de peso no processo de integração harmônica da diversidade sexual ao mundo do trabalho. Isso se opera por meio da elaboração de instrumentos normativos de proteção à dignidade do trabalhador homossexual e de repressão à discriminação homofóbica no trabalho, concatenados a incentivo legais à promoção e à celebração da diferença no contexto laboral. Com efeito:

(...) As leis, por si sós, não eliminarão a homofobia (...). Mesmo assim, a legislação é um baluarte fundamental na luta para acabar com a discriminação no ambiente de trabalho. Sem ela, a orientação sexual continuará a representar uma vulnerabilidade no nível mais básico dos direitos econômicos: ou você não será contratado em um emprego para o qual é qualificado, ou será demitido porque sua orientação foi descoberta ${ }^{357}$.

Com esse enfoque e à vista da vocação do Direito do Trabalho para, sob o paradigma do Estado Democrático de Direito, constituir um aparato mínimo de amparo, defesa e promoção da dignidade e dos direitos fundamentais do trabalhador, far-se-á a análise do tratamento contemporâneo que o Direito brasileiro e o Direito internacional, nos planos legislativo e jurisprudencial, dispensam aos temas da homossexualidade, do heterossexismo e da homofobia, no mundo do trabalho.

${ }^{357}$ HEWLETT, Sylvia Ann et al. The power of "out" 2.0: LGBT in the workplace. Nova York: Center for Talent Innovation, 2013, p. 20. 


\section{O PRINCÍPIO FUNDAMENTAL DA DIGNIDADE DA PESSOA HUMANA E A PROIBIÇÃO À DISCRIMINAÇÃO POR ORIENTAÇÃO SEXUAL}

\subsection{Reconhecimento, Direito e Dignidade}

De acordo com Honneth, a edificação da identidade humana depende da experiência do reconhecimento intersubjetivo, vez que a compreensão do eu como agente individuado, calcada numa relação bem-sucedida do sujeito consigo mesmo, decorre do confronto entre indivíduos que, progressivamente, atestam de forma recíproca as suas autonomias ${ }^{358}$. Nessa esteira:

(...) a reprodução da vida social se efetua sob o imperativo de um reconhecimento recíproco porque os sujeitos só podem chegar a uma autorrelação prática quando aprendem a se conceber, da perspectiva normativa de seus parceiros de interação, como seus destinatários sociais $^{359}$.

Sob esse enfoque, Honneth identifica três formas básicas de reconhecimento que, no processo de individuação, confirmam paulatinamente novas dimensões identitárias e convergem, assim, para a capacidade do sujeito de se referir positivamente a si mesmo, como um integrante autônomo da sociedade. São elas: o amor, o Direito e a estima social ${ }^{360}$.

Por meio do reconhecimento oriundo das relações primárias emotivas, como o amor e a amizade, os sujeitos, confirmando-se enquanto seres carentes, estruturam uma autoconfiança baseada na percepção mútua de que, embora autônomos, podem contar com a dedicação afetiva de um para com o outro ${ }^{361}$. Já pelo reconhecimento pertinente às relações jurídicas, os indivíduos, vendo-se mutuamente na condição de agentes moralmente imputáveis, sedimentam o seu autorrespeito, podendo se identificar como sujeitos de direitos e deveres da comunidade política ${ }^{362}$. Por derradeiro, é pelo reconhecimento atrelado às relações de estima social que as formas de autorrealização de cada pessoa têm seu valor social confirmado, possibilitando aos indivíduos estruturar um sentimento de autoestima ${ }^{363}$.

\footnotetext{
${ }^{358}$ HONNETH, Axel. Luta por reconhecimento: a gramática moral dos conflitos sociais. São Paulo: Ed. 34, 2003, p. 120-125.

359 lbid., p. 125.

360 lbid., p. 266.

${ }^{361}$ lbid., p. 159-178.

${ }^{362}$ lbid., p. 179-196.

${ }^{363}$ Ibid., p. 198-211.
} 
Se o desenvolvimento progressivo de diferentes modos de reconhecimento confere integridade à identidade humana e permite ao indivíduo construir uma imagem positiva de si mesmo; na contramão, a vivência da recusa de reconhecimento estremece a autorrelação prática da pessoa e se desdobra em modalidades igualmente específicas de desrespeito. A autoconfiança, por exemplo, é minada por meio das violações à integridade física, atacando o mais basilar senso de autonomia do indivíduo; o autorrespeito, por sua vez, corrói-se pela exclusão de direitos ou pela privação do sujeito das condições para gozá-los e participar da formação pública da vontade de forma paritária; e a autoestima, finalmente, se esfacela pela experiência da ofensa e da degradação, tolhendo o valor social da forma de vida que o sujeito encontra para se realizar ${ }^{364}$.

A experiência com o desrespeito, não obstante, conquanto nociva à formação identitária, pode tornar-se motor de transformação social. Com efeito, a injustiça decorrente da negativa de reconhecimento acede à consciência por meio de emoções negativas como a vergonha ${ }^{365}$ e a raiva, gerando uma tensão afetiva que só pode se dissipar na medida em que se converte em ação (reação) voltada a modificar e a ampliar os padrões sociais de reconhecimento ${ }^{366}$. É nesse sentido que, para Honneth, a evolução moral da sociedade pode ser vista como resultado da luta permanente por reconhecimento, travada a partir da vivência do desrespeito ${ }^{367}$.

Sob uma perspectiva deontológica e crítica à concepção identitária das relações de reconhecimento traçada por Honneth, que estariam firmadas em juízos éticos sobre a boa vida e os pressupostos da autorrealização, Fraser aborda as reivindicações por reconhecimento como uma exigência de justiça ${ }^{368}$.

Nesse rumo, sustenta que o reconhecimento deveria ser encarado como uma questão de status, o que implica apreender as lutas por reconhecimento não como demandas pela valoração positiva de identidades sociais (estima), a fim de permitir aos indivíduos o pleno desenvolvimento da subjetividade, mas sim como reivindicações dos membros de determinados grupos para que se thes reconheça

\footnotetext{
${ }^{364}$ HONNETH, Axel. Luta por reconhecimento: a gramática moral dos conflitos sociais. São Paulo: Ed. 34, 2003, p. 214-217.

${ }^{365}$ A respeito da faceta reativa da vergonha, consultar: GAULEJAC, Vincent de. As origens da vergonha. São Paulo: Via Lettera Editora e Livraria, 2006.

${ }^{366}$ HONNETH, op. cit., p. 220-224.

367 Ibid., p. 156.

${ }^{368}$ FRASER, Nancy. Reconhecimento sem ética?. Lua Nova, São Paulo, n. 70, p. 101-138, 2007, p. 137.
} 
integralmente a condição de parceiros na interação social, remediando situações de subordinação que os privem da possibilidade de uma participação paritária na vida em comunidade:

\begin{abstract}
Entender o reconhecimento como uma questão de status significa examinar os padrões institucionalizados de valoração cultural em função de seus efeitos sobre a posição relativa dos atores sociais. Se e quando tais padrões constituem os atores como parceiros, capazes de participar como iguais, com os outros membros, na vida social, aí nós podemos falar de reconhecimento recíproco e igualdade de status. Quando, ao contrário, os padrões institucionalizados de valoração cultural constituem alguns atores como inferiores, excluídos, completamente "os outros" ou simplesmente invisíveis, ou seja, como menos do que parceiros integrais na interação social, então nós podemos falar de não reconhecimento e subordinação de status ${ }^{369}$.
\end{abstract}

Segundo Fraser, a adoção do modelo de status, mantendo a discussão sobre o reconhecimento no campo da moral (correto) e afastando-a do campo da ética (bom), para o qual se inclinaria o modelo identitário defendido por Honneth, além de evitar a essencialização de identidades sociais e a imposição sectária de concepções de bem (que, em geral, não são compartilhadas por todos), é vantajosa por se sustentar em uma concepção tridimensional de justiça, entendida como paridade de participação, que permite articular redistribuição, reconhecimento e representação ${ }^{370}$.

Se compreendida como resultado de estruturas sociais que permitam concretamente aos seus integrantes interagir uns com os outros como iguais, a realização da justiça passa a depender, assim, do atendimento de três condições cumulativas: em primeiro lugar, a garantia da independência econômica dos indivíduos, que se alcança por meio de uma melhor distribuição de recursos materiais; em segundo lugar, a construção de padrões institucionalizados de valores que, em substituição a padrões de subordinação do diferente, promovam o reconhecimento e o respeito recíprocos de todos os membros da comunidade política como parceiros integrais na interação, independentemente de concepções individuais sobre o que seriam as melhores formas de se viver ${ }^{371}$; e, em terceiro lugar, no campo da política, o aperfeiçoamento da representação, para que as demandas por reconhecimento e redistribuição possam ser apresentadas e respondidas, de forma paritária, pelas instituições - o que se faz por meio do aprimoramento das estruturas e

${ }^{369}$ FRASER, Nancy. Reconhecimento sem ética?. Lua Nova, São Paulo, n. 70, p. 101-138, 2007, p. 108.

370 Ibid., p. 109-110.

${ }^{371}$ lbid., p. 118-119. 
procedimentos de tomada de decisão, bem como dos critérios empregados para enquadrar sujeitos como membros da comunidade política, com legitimidade para formular demandas por justiça ${ }^{372}$.

Seja sob o enfoque deontológico de Fraser ou sob a perspectiva ética de Honneth, cumpre notar que o Direito se torna forma autônoma de reconhecimento somente a partir da modernidade, sobretudo quando, sob o paradigma do constitucionalismo e dos direitos humanos, distancia-se das relações de honra tradicionais e emerge como "expressão dos interesses universalizáveis de todos os membros da sociedade, de sorte que ele não admita mais, segundo sua pretensão, exceções e privilégios" ${ }^{373}$.

Mas o Direito só pode efetivamente assumir essa conotação universalizante (e, assim, convolar-se em arena de luta ou reivindicação por reconhecimento) se cada indivíduo puder aquiescer conscientemente às normas jurídicas, compreendendo-se como um integrante livre e igual da comunidade política, apto a contribuir para a formação racional da vontade. É por isso que, na perspectiva contemporânea, o Direito passa a se ancorar na premissa da igual imputabilidade moral de todas as pessoas, porquanto detentoras de uma qualidade intrínseca que lhes caracteriza enquanto seres humanos: a dignidade ${ }^{374}$.

Essa mesma premissa se encontra na base da concepção de justiça esposada por Fraser, que pressupõe um consenso de que o igual valor moral de todo ser humano é o que fundamenta a participação de cada sujeito na interação social como parceiro. E, nesses termos, mais do que um abalo à esfera psíquica, a negativa de reconhecimento de que padecem algumas pessoas exsurge, desse modo, como expressão de injustiça social ${ }^{375}$.

A despeito das diferenças de perspectiva, os dois modelos, como se vê, convergem para uma preocupação nuclear do Direito contemporâneo para com essa qualidade intrínseca à pessoa humana e às capacidades dela decorrentes, expressando-se pela adjudicação de direitos básicos que a assegurem e promovam

\footnotetext{
${ }^{372}$ FRASER, Nancy. Scales of justice: reimagining political space in a globalizing world. New York: Columbia University Press, 2008, p. 12-29.

${ }^{373}$ HONNETH, Axel. Luta por reconhecimento: a gramática moral dos conflitos sociais. São Paulo: Ed. 34, 2003, p. 179.

${ }^{374}$ Ibid., p. 180-188.

${ }^{375}$ FRASER, Nancy. Reconhecimento sem ética?. Lua Nova, São Paulo, n. 70, p. 101-138, 2007, p. 120-121.
} 
o seu desenvolvimento. A luta por reconhecimento nas relações jurídicas, em assim sendo, é uma luta pela confirmação cada vez mais complexa e alargada do sentido de dignidade. A dignidade se apoia na premissa do igual valor de toda pessoa humana para postular a ampliação de direitos e a inclusão paritária de grupos marginalizados, expandindo o horizonte de propriedades que definem e resguardam o agente moralmente imputável ${ }^{376}$.

E cabe falar em disputa por alargamento e complexificação da ideia de dignidade, na perspectiva jurídica das relações de reconhecimento, porque se trata de um conceito multidimensional, mutável, com delimitações imprecisas e elementos até mesmo redundantes, em certa medida. Afinal, se ela evoca o igual valor de cada ser humano, ao mesmo tempo, representa a qualidade distintiva que os caracteriza enquanto humanos ${ }^{377}$.

Mas, em que pese seja difícil lhe precisar uma definição, a noção de dignidade instintivamente vem à mente como algo quase palpável, nas situações concretas em que é vilipendiada. A violação física e psicológica, a humilhação, a marginalização socioeconômica, a injusta negativa de participação paritária na condução da vida comunitária são algumas dentre tantas outras circunstâncias que, no passar do tempo, despertam ou passam a despertar o sentimento generalizado de que não se dispensou a um indivíduo ou grupo o mínimo respeito e consideração que seriam devidos a qualquer pessoa, em virtude de sua própria condição humana.

De fato, apontar aquilo que não se enquadra na ideia de dignidade é bem mais fácil que o árduo exercício de conceituá-la, pois, em função mesmo desta dimensão valorativa que a embasa, aberta e em constante construção, bem como de sua natureza relacional, intersubjetiva, defini-la de maneira fixa e imutável não se faz possível $^{378}$.

Apesar dessas limitações, Sarlet propõe um conceito que ele mesmo assume como tão provisório quanto exige a fluidez do termo, razão pela qual vem o submetendo a reiterados ajustes ao longo dos anos. Ainda assim, a iniciativa tem grande potencial explicativo por reunir sinteticamente, entre tantas divergências

\footnotetext{
${ }^{376}$ HONNETH, Axel. Luta por reconhecimento: a gramática moral dos conflitos sociais. São Paulo: Ed. 34, 2003, p. 188-189.

377 SARLET, Ingo Wolfgang. Dignidade da pessoa humana e direitos fundamentais na Constituição Federal de 1988. 9. ed. Porto Alegre: Livraria do Advogado Editora, 2011, p. 49-50.

${ }^{378}$ Ibid., p. 51-52.
} 
teóricas, os principais elementos que se costumam destacar na ideia de dignidade da pessoa humana:

Assim sendo, temos por dignidade da pessoa humana a qualidade intrínseca e distintiva reconhecida em cada ser humano que o faz merecedor do mesmo respeito e consideração por parte do Estado e da comunidade, implicando, neste sentido, um complexo de direitos e deveres fundamentais que assegurem a pessoa tanto contra todo e qualquer ato de cunho degradante e desumano, como venham a lhe garantir as condições existenciais mínimas para uma vida saudável, além de propiciar e promover sua participação ativa e corresponsável nos destinos da própria existência e da vida em comunhão com os demais seres humanos, mediante o devido respeito aos demais seres que integram a rede da vida ${ }^{379}$.

Percebe-se, de pronto, o caráter multifacetado da dignidade. De um lado, ela conta com uma dimensão ontológica, que finca raízes no pensamento kantiano, para o qual o homem, enquanto ser racional, pois dotado de consciência, é um fim em si mesmo, nunca um meio, e, bem assim, qualifica-se por um valor intrínseco, insubstituível, não havendo preço que a ele se equipare ${ }^{380}$. Este valor se vincula à potencial liberdade humana para racionalmente conduzir os rumos da própria existência, isto é, para se autodeterminar. De outro lado, porém, a dignidade comporta uma dimensão cultural, pois a definição das condições necessárias à vida digna se desenvolve e se altera no curso da história, acompanhando as mudanças nos parâmetros morais da sociedade ${ }^{381}$.

Verifica-se, ademais, que a dignidade prescinde do Estado ou do Direito para existir. Ela não é, afinal, uma concessão. Mas exatamente por estar sujeita a cerceamentos e violações, quando o seu reconhecimento é negado, depende do monopólio estatal da força, por meio da estruturação de um sistema de direitos e deveres na ordem jurídica, para que, reconhecendo-a como limite intransponível, se ergam barreiras em sua defesa e estímulos a seu pleno desenvolvimento. Tem, portanto, uma faceta negativa e outra positiva perante o Estado e a sociedade: constitui a última fronteira à preservação da humanidade, que não pode ser

\footnotetext{
${ }^{379}$ SARLET, Ingo Wolfgang. Dignidade da pessoa humana e direitos fundamentais na Constituição Federal de 1988. 9. ed. Porto Alegre: Livraria do Advogado Editora, 2011, p. 73.

${ }^{380}$ KANT, Immanuel. Fundamentação da metafísica dos costumes. Trad. Paulo Quintela. Lisboa: Edições 70, 2007, p. 67-77.

${ }^{381}$ SARLET, op. cit., p. 55-57.
} 
transgredida, mas também uma tarefa, pois requer o fornecimento de condições para que possa se manifestar plenamente ${ }^{382}$.

\subsection{A dignidade da pessoa humana como matriz principiológica do Estado Democrático de Direito}

A virada incisiva do Direito em prol da figura humana, com vistas a tutelar e promover sua dignidade, é resultado de uma conjuntura de graves violações a esse valor que se desdobrou no início do século $\mathrm{XX}$.

Como bem lembra Piovesan, o conflito entre o eu e o outro foi o catalisador dos mais emblemáticos episódios de transgressão ao que hoje se entende por pressuposto básico para a vida digna. A inaptidão para reconhecer a alteridade e nela se reconhecer, com efeito, conduz à percepção do diferente como "um ser menor em dignidade e direitos, ou, em situações limites, um ser esvaziado mesmo de qualquer dignidade" 383 .

O outro desumanizado não é merecedor do respeito e da consideração devidos àqueles com os quais o eu se identifica. Sua vida tem menor valor e seu sofrimento não desperta empatia. Objetificando-se o diferente, ele fica exposto à instrumentalização e, não raro, à possibilidade de extermínio ${ }^{384}$.

E foi essa, precisamente, a experiência atravessada em escala global, na sequência de duas grandes guerras, em meio a um processo cada vez mais intenso de diferenciação e complexificação social, que despertou a atenção para a fragilidade da condição humana. As violações à dignidade atingiram um nível crítico na Segunda Guerra Mundial, com aproximadamente 60 milhões de óbitos, tendo no genocídio perpetrado pelo regime nazista o símbolo mais insólito do completo menoscabo para com a diferença e, particularmente, para com o valor humano intrínseco até então alcançado $^{385}$.

\section{Como destaca Barroso:}

\footnotetext{
382 SARLET, Ingo Wolfgang. Dignidade da pessoa humana e direitos fundamentais na Constituição Federal de 1988. 9. ed. Porto Alegre: Livraria do Advogado Editora, 2011, p. 58.

${ }^{383}$ PIOVESAN, Flávia. Igualdade, diferença e direitos humanos: perspectivas global e regional. In: SARMENTO, Daniel; IKAWA, Daniela; PIOVESAN, Flávia (Coord.). Igualdade, diferença e direitos humanos. Rio de Janeiro: Editora Lumen Juris, 2010, p. 48.

${ }^{384}$ Ibid., p. 48.

${ }^{385}$ HUNT, Lynn. A invenção dos direitos humanos: uma história. São Paulo: Companhia das Letras, 2009, p. 202-203.
} 
O princípio da dignidade humana identifica um espaço de integridade a ser assegurado a todas as pessoas por sua só existência no mundo (...). A dignidade relaciona-se tanto com a liberdade e valores do espírito quanto com as condições materiais de subsistência. O desrespeito a esse princípio terá sido um dos estigmas do século que se encerrou e a luta por sua afirmação, um símbolo do novo tempo. Ele representa a superação da intolerância, da discriminação, da exclusão social, da violência, da incapacidade de aceitar o outro, o diferente, na plenitude de sua liberdade de ser, pensar e $\operatorname{criar}^{386}$.

Essa experiência catalisou, portanto, um movimento multilateral com vistas à elaboração de instrumentos que impusessem freios e sanções ao exercício destrutivo do poder em face da dignidade humana. Como resultado, foram criadas estruturas institucionais e normativas, em nível estatal e supranacional (por meio de sistemas globais e regionais), voltadas à garantia das condições básicas para a vida digna. Destacam-se, nesse quadro, o paradigma do Estado Democrático de Direito e a noção contemporânea de direitos humanos ${ }^{387}$.

A esse respeito, anota Carvalho Netto:

Desde o seu nascimento, uma sociedade que se diferencia, que se especializa para poder se reproduzir num grau de complexidade tão grande que exigiu a invenção dos direitos humanos, dos direitos fundamentais; requereu a afirmação, a um só tempo, paradoxal e estruturalmente móvel, do reconhecimento recíproco da igualdade e da liberdade de todos os seus membros, ou seja, tornou, plausível e exigiu a idéia de que somos, pela primeira vez na história, uma sociedade na qual nos reconhecemos como pessoas iguais, porque ao mesmo tempo livres. Livres para sermos diferentes, uma vez que somos diferentes, plurais, em dotes e potencialidades desde 0 nascimento e nos reconhecemos o direito de sermos diferentes e de exercermos as nossas diferenças, ou seja, de sermos livres e de exercermos nossas liberdades. E, ainda assim, ou melhor, precisamente por isso, nos respeitamos como iguais ${ }^{388}$.

Consoante frisa Perez Luño, os direitos humanos são uma categoria histórica, cujas raízes remontam às ideias inspiradas pelas Revoluções Liberais do século XVIII e ao lluminismo, sobretudo o jusnaturalismo, de onde deriva a noção de que a

386 BARROSO, Luís Roberto. Curso de direito constitucional contemporâneo: os conceitos fundamentais e a construção do novo modelo. São Paulo: Saraiva, 2009, p. 252.

387 Sobre a origem histórica da ideia de direitos fundamentais e direitos humanos, cf. PIOVESAN, Flávia. Igualdade, diferença e direitos humanos: perspectivas global e regional. In: SARMENTO, Daniel; IKAWA, Daniela; PIOVESAN, Flávia (Coord.). Igualdade, diferença e direitos humanos. Rio de Janeiro: Editora Lumen Juris, 2010, p. 51; e SARLET, Ingo Wolfgang. A eficácia dos direitos fundamentais: uma teoria geral dos direitos fundamentais na perspectiva constitucional. 10. ed. Porto Alegre: Livraria do Advogado Editora, 2011, p. 61. 388 CARVALHO NETTO, Menelick de. A Hermenêutica Constitucional e os desafios postos aos Direitos Constitucionais. In: José Adécio Leite Sampaio. (Org.). Jurisdição Constitucional e Direitos Fundamentais. Belo Horizonte: Del Rey, 2003 , p. 143. 
racionalidade, como traço comum à humanidade, confere a todo indivíduo direitos básicos de validade universal ${ }^{389}$. Exatamente por não se tratar de uma categoria atemporal, o reconhecimento de novas posições jurídicas como direitos humanos foi se alargando e se transformando ao longo do tempo.

Nesse sentido, costuma-se apontar três dimensões dos direitos humanos que, no curso da história, foram se descortinando e se implicando reciprocamente, de modo a formar um conjunto indivisível e interdependente (direitos civis e políticos; direitos econômicos, sociais e culturais; e direitos de solidariedade e fraternidade $)^{390}$. Cada nova classe de direitos básicos cumulativamente institucionalizado importa a revisitação e a releitura dos paradigmas anteriores ${ }^{391}$, representando a confirmação de uma nova faceta da dignidade da pessoa humana ${ }^{392}$, de cuja tutela jurídica passa a depender para que possa se concretizar ${ }^{393}$.

O resgate dessas concepções no período posterior à Segunda Guerra Mundial, sob o signo da universalidade desses direitos e de sua indivisibilidade,

${ }^{389}$ LUÑO, Antonio Enrique Pérez. La universalidade de los derechos humanos y el Estado constitucional. 1. ed. Bogotá: Universidad Externado de Colombia, 2002, p. 23.

${ }^{390} \mathrm{Na}$ perspectiva da origem histórica, a doutrina indica que a primeira dimensão é a dos direitos civis e políticos, característica do pensamento liberal do século XVIII. Constitui-se basicamente de direitos de participação política e direitos de caráter negativo, impondo limites à intervenção do Estado no âmbito de autonomia privado, tais como o direito à vida, à propriedade e a liberdades fundamentais, como reunião e manifestação. Abarca, ainda, a ideia, formal e abstrata, de que todo indivíduo é igual perante a lei. No que tange à segunda dimensão, cujas raízes históricas remetem ao período da industrialização europeia do século XIX, anotam-se os direitos de viés econômicos, sociais e culturais. Frutos das reivindicações contra desigualdades concretas, são direitos voltados a promover a justiça social e a assegurar a participação de todos na vida comunitária, em condições paritárias. Assim sendo, boa parte deles exige a atuação prestacional (positiva) do Estado e uma concepção material de igualdade, atenta a exigências por redistribuição, decorrentes das disparidades socioeconômicas concretas. São exemplos o direito à educação, à saúde e os direitos do sujeito trabalhador, de ordem tanto individual quanto coletiva. A terceira dimensão, finalmente, conta com os direitos de solidariedade e fraternidade, que visam a resguardar grupos e, bem por isso, são de titularidade difusa ou coletiva. Destes, vale citar o direito à paz e ao meio ambiente. SARLET, Ingo Wolfgang. A eficácia dos direitos fundamentais: uma teoria geral dos direitos fundamentais na perspectiva constitucional. 10. ed. Porto Alegre: Livraria do Advogado, p. 45-48.

${ }^{391}$ Disto resulta, por exemplo, a inserção da faceta social nos direitos civis e políticos. Não se fala, pois, sob o paradigma contemporâneo, na garantia de um direito à propriedade ou à livre iniciativa egoístico e ilimitado - essas posições jurídicas são tuteladas na medida em que atendam à finalidade social.

392 HONNETH, Axel. Luta por reconhecimento: a gramática moral dos conflitos sociais. São Paulo: Ed. 34, 2003, p. 204.

393 SARLET, Ingo Wolfgang. Dignidade da pessoa humana e direitos fundamentais na Constituição Federal de 1988. 9. ed. Porto Alegre: Livraria do Advogado Editora, 2011, p. 108. 
representou a introdução de uma diretriz ética em nível internacional, decorrente de um movimento global de resistência e defesa do valor da pessoa humana. Nesse rumo, para Piovesan, "A ética dos direitos humanos é a ética que vê no outro um ser merecedor de igual consideração e profundo respeito, dotado do direito de desenvolver as potencialidades humanas, de forma livre, autônoma e plena" 394.

Tem-se como marco inaugural dessa leitura contemporânea dos direitos humanos a criação da Organização das Nações Unidas (ONU) e, principalmente, a aprovação da Declaração Universal dos Direitos Humanos de 1948. Firmou-se aí a base para o desenvolvimento, de forma complementar, dos sistemas global e regional de tutela dos direitos humanos ${ }^{395}$.

Vale destacar, de todo modo, o pioneirismo dos organismos dedicados à salvaguarda dos direitos trabalhistas no tocante à reconstrução dessa agenda. Com efeito, desde a sua instituição pelo Tratado de Versalhes, que selou o fim da Primeira Guerra Mundial, a Organização Internacional do Trabalho inovou ao assentar as bases para um regime funcional de direitos humanos amplamente reconhecido pelos Estados ao redor do globo. Esse compromisso foi renovado no ano de 1944, em face dos desdobramentos catastróficos da Segunda Guerra Mundial. Na ocasião, a OIT adotou a Declaração de Filadélfia ${ }^{396}$ como anexo à sua Constituição, uma verdadeira carta de direitos e de princípios jurídicos universais que, embora focados na perspectiva trabalhista, são voltados à preservação da paz mundial, com base na justiça social e na preservação da dignidade da pessoa humana. O diploma serviria de inspiração para a Carta da Organização das Nações Unidas, de 1945, e para a emblemática Declaração Universal dos Direitos Humanos ${ }^{397}$.

Ao fim da Segunda Guerra Mundial, a rearticulação do constitucionalismo com a democracia, fez surgir também um novo modelo de organização política e jurídica, de inspiração humanista, denominado Estado Democrático de Direito.

\footnotetext{
394 PIOVESAN, Flávia. Igualdade, diferença e direitos humanos: perspectivas global e regional. In: SARMENTO, Daniel; IKAWA, Daniela; PIOVESAN, Flávia (Coord.). Igualdade, diferença e direitos humanos. Rio de Janeiro: Editora Lumen Juris, 2010, p. 47-48. ${ }^{395}$ Ibid., p. 53-54.

${ }^{396}$ Leitura complementar sobre o tema: SUPIOT, Alain. O espírito de Filadélfia: a justiça social diante do mercado total. Porto Alegre: Sulina, 2014.

${ }^{397}$ BEZERRA, Ricardo dos Santos. Discriminação por orientação sexual na perspectiva dos direitos humanos: um panorama da legislação e ações afirmativas no Brasil. Tese (Doutorado em Direito). Faculdade de Direito da Universidade de Salamanca (USAL), Salamanca, 2011, p. 68-69.
} 
Manifestando-se primeiramente na Constituição italiana, de 1947, e na Constituição alemã, de 1949, esse modelo se expandiu e se consolidou, na segunda metade do século $X X$, como versão amadurecida e aperfeiçoada dos paradigmas anteriores do Estado Liberal de Direito e do Estado Social de Direito ${ }^{398}$.

No Brasil, encerrando um regime político e institucional autoritário que, por décadas, fora marcado pelo cerceamento a direitos e às liberdades, a Constituição Federal de 1988, promulgada em meio ao processo de redemocratização do país, sinalizou a adoção formal e substancial do paradigma de Estado Democrático de Direito, estampado já em seu art. $1^{\circ}$, notabilizando-se ainda por assentar, como princípio fundamental da República, a dignidade da pessoa humana (art. $1^{\circ}$, III).

O advento desse novo modelo demarca transições em relação ao paradigma tradicional de Estado de Direito, sobretudo a passagem de um sistema baseado na supremacia da lei para outro pautado pela supremacia da Constituição, no qual a validade das leis passa a depender de sua adequação ao parâmetros normativos estabelecidos no Texto Constitucional ${ }^{399}$. Outrossim, reconhece-se, no Estado Constitucional contemporâneo, que o ordenamento jurídico é composto não apenas por regras, mas também por princípios ${ }^{400}$ dotados de função normativa própria ${ }^{401}$.

Atente-se, porém, para o fato de que o tripé no qual se sustenta o Estado Democrático de Direito, como destaca Godinho Delgado, é composto pela

398 BARROSO, Luís Roberto. Curso de direito constitucional contemporâneo: os conceitos fundamentais e a construção do novo modelo. São Paulo: Saraiva, 2009, p. 245-246.

399 Ibid., p. 245-246.

${ }^{400}$ Acerca da discussão teórica sobre a distinção entre princípios e regras, vale lembrar que, para Dworkin, regras incidem na forma do "tudo-ou-nada", isto é, ou são efetivamente válidas ou inválidas. As exceções ao que prescrevem se tornam possíveis apenas se contidas no próprio enunciado. Diferentemente, o princípio "enuncia uma razão que conduz o argumento em uma certa direção, mas [ainda assim] necessita uma decisão particular". São normas que contêm um nível de análise de que carecem as regras: da relevância ou do peso, visto que, quando princípios são confrontados, apura-se no caso concreto qual padrão deve prevalecer, sem que, com isso, se extirpe do direito o princípio afastado. DWORKIN, Ronald. Levando os direitos a sério. 2. ed. São Paulo: Martins Fontes, 2007, p. 35-43. Já para Alexy, princípios constituem mandados de otimização (ou mandados a serem otimizados, em sua formulação mais recente), postulados que requererem realização na maior medida possível. Admitem, portanto, ao contrário das regras, cumprimento em graus variados, de acordo com as circunstâncias fáticas e jurídicas de cada caso. ALEXY, Robert. Teoria de los Derechos Fundamentales. Madri: Centro de Estúdios Políticos y Constitucionales, 2001, p. 86-87. Sobre o tema, consultar: NEVES, Marcelo. Entre hidra e Hércules: princípios e regras constitucionais como diferença paradoxal do sistema jurídico. São Paulo: WMF Martins Fontes, 2013.

401 DELGADO, Gabriela Neves. Direito fundamental ao trabalho digno. 2. ed. São Paulo: LTr, 2015, p. 49 
centralidade conferida à pessoa humana, com a dignidade que lhe é inerente; pela sociedade civil democrática e inclusiva e pela sociedade política de caráter também democrático e inclusivo ${ }^{402}$.

A democracia é, nesse quadro, um dos pilares desse modelo de Estado. No entanto, é preciso salientar que, muito embora, numa concepção estrita e clássica, ela possa ser definida simplesmente como um regime político caracterizado pela ampla participação popular, tanto direta quanto mediante representação, na organização e na condução do Estado; em sua acepção contemporânea, a ideia de democracia transpassa os limites do âmbito político-institucional, espraiando-se por todas as esferas da vida social. Nesse sentido, também no plano da sociedade civil, a contemporaneidade guarda expectativas quanto à ampla participação no exercício do poder, impingindo-Ihe restrições. Logo, como valor ínsito a ambas as esferas, a disseminação da ideia democrática estimula a inclusão não apenas política, como também a inclusão social, econômica e cultural ${ }^{403}$.

Sob esse viés, Delgado conceitua a democracia como:

(...) método e institucionalização de gestão da sociedade política e da sociedade civil, baseada na garantia firme das liberdades públicas, liberdades sociais e liberdades individuais, com participação ampla das diversas camadas da população, sem restrições decorrentes de sua riqueza e poder pessoais, dotada de mecanismos institucionalizados de inclusão e de participação dos setores sociais destituídos de poder e de riqueza (... $)^{404}$.

Já a adoção da dignidade como princípio fundamental do Estado Constitucional contemporâneo, na forma como declara a Constituição brasileira de 1998, significa a confirmação de que ele, Estado, tem a sua existência voltada à pessoa humana, que deve ser compreendida como a finalidade última da atuação estatal e nunca um meio para a realização de outros objetivos ${ }^{405}$.

Dessa característica do Estado Democrático de Direito decorre, aliás, outro de seus elementos intrínsecos, a conexão inquebrantável que mantém com os direitos fundamentais. No plano nacional, a Constituição Federal de 1988 possui importância

${ }^{402}$ DELGADO, Maurício Godinho. Constituição da República, Estado Democrático de Direito e Direito do Trabalho. In: DELGADO, Maurício Godinho; DELGADO, Gabriela Neves. Constituição da República e direitos fundamentais. 3. ed. São Paulo: LTr, 2015, p. 43. 403 lbid., p. 34.

404 Ibid., p. 32.

405 SARLET, Ingo Wolfgang. Dignidade da pessoa humana e direitos fundamentais na Constituição Federal de 1988. 9. ed. Porto Alegre: Livraria do Advogado Editora, 2011, p. 80. 
constitucional e simbólica ímpar nesse sentido, pois apresenta a mais densa e ampla carta de direitos e garantias fundamentais já promulgada no país ${ }^{406}$.

Do ponto de vista conceitual, predomina o entendimento de que, se a concepção de direitos humanos remete às posições jurídicas mais básicas, universais, que se atribuem a todo indivíduo tão somente por sua condição humana, sendo enunciados em diplomas internacionais; os direitos fundamentais, por sua vez, consubstanciam a positivação, em nível constitucional, desses direitos e garantias nucleares, tendo por referência os membros de uma dada comunidade política ${ }^{407}$.

Esses direitos são assim denominados, propriamente, por serem assumidos, ao lado dos princípios estruturais e organizacionais do Estado, como fundamento substancial do ordenamento jurídico. Eles representam a introdução, por meio do poder constituinte, de uma dimensão axiológica no direito positivo, porquanto expressam valores considerados elementares, numa perspectiva histórica, pela comunidade política ${ }^{408}$.

A unidade de valor em torno da qual gravitam os direitos fundamentais e que Ihes confere sistematicidade é a dignidade da pessoa humana, fonte da qual emanam como exigências para sua realização. Isso porque os direitos e garantias expressamente elencados na Constituição, bem como aqueles que se podem dessumir de sua matriz principiológica, são os meios pelo qual se viabiliza juridicamente a proteção e a promoção das potencialidades da pessoa humana ${ }^{409}$.

Nessa esteira, os direitos fundamentais figuram, no Estado Constitucional contemporâneo, não apenas como direitos subjetivos, cujas violações fazem surgir pretensões passíveis de tutela pela via judicial. Eles se expressam também sob uma perspectiva jurídico-objetiva, irradiando valores que orientam a elaboração, a aplicação e a interpretação das normas jurídicas. Ainda nesta concepção, delineiam objetivos a serem perseguidos pela sociedade e, principalmente, pelo poder público,

\footnotetext{
${ }^{406}$ Cf. BARROSO, Luís Roberto. Neoconstitucionalismo e constitucionalização do direito: o triunfo tardio do direito constitucional no Brasil. Disponível em: $<$ http://www.luisrobertobarroso.com.br/wpcontent/themes/LRB/pdf/neoconstitucionalismo_e_constitucionalizacao_do_direito_pt.pdf>. Acesso em 06/04/2016.

407 SARLET, Ingo Wolfgang. A eficácia dos direitos fundamentais: uma teoria geral dos direitos fundamentais na perspectiva constitucional. 10. ed. Porto Alegre: Livraria do Advogado Editora, 2011, p. 29-31.

${ }^{408}$ Ibid., p. 29-31.

${ }^{409}$ Ibid., p. 29-31.
} 
ao qual impõem, com caráter vinculante, mandamentos ou deveres fundamentais de proteção contra violações por parte do próprio Estado ou de agentes particulares ${ }^{410}$.

Essa especificidade é o que faz do Estado Democrático de Direito o que Silva denomina de Estado de Direitos Fundamentais:

Por Estado de Direitos Fundamentais entenda-se aquele vinculado objetivamente aos direitos fundamentais, ou seja, o Estado em que a supremacia da Constituição e as relações entre as funções de Poder ocorrem de forma estritamente vinculadas aos direitos fundamentais, os quais, por sua vez, se concretizam de forma irradiante (para todos os ramos da ciência jurídica), de forma dirigente (para todos os atos estatais) e de forma horizontal (para todos os atos da vida privada) ${ }^{411}$.

Em ambas as dimensões, subjetiva e objetiva, os direitos fundamentais, como derivação e exigência de concretização da dignidade humana ${ }^{412}$, se prestam a tutelar a autonomia de seus titulares, a evitar e a corrigir disparidades de natureza distributiva, assim como a remodelar padrões culturais excludentes, com vistas a fomentar o reconhecimento, permitindo a participação de todos os indivíduos, enquanto agentes morais autônomos, como parceiros de igual valor na tomada das decisões que definirão os rumos da comunidade política a que pertencem ${ }^{413}$.

Os direitos fundamentais servem, assim, à função de trincheira contra movimentos autoritários que, na sua ausência, poderiam emergir e se disseminar inclusive em Estados de regime político democrático, como comprovou a experiência da Segunda Guerra Mundial. No Estado Constitucional contemporâneo, há, portanto, um necessário vínculo entre a democracia e os direitos fundamentais ${ }^{414}$.

Perceba-se que essa relação, no referido paradigma de Estado, é de interdependência e implicação recíproca ${ }^{415}$. De um lado, o constitucionalismo que desponta ao fim da Segunda Guerra Mundial, firmado sobre o princípio da dignidade da pessoa humana (que é a fonte dos direitos fundamentais), só pode se sustentar na

${ }^{410}$ SARLET, Ingo Wolfgang. A eficácia dos direitos fundamentais: uma teoria geral dos direitos fundamentais na perspectiva constitucional. 10. ed. Porto Alegre: Livraria do Advogado Editora, 2011, p. 141-149.

411 SILVA, Christine Oliveira Peter da. Transjusfundamentalidade: diálogos judiciais transnacionais sobre direitos fundamentais. Tese (Doutorado em Direito). Faculdade de Direito da Universidade de Brasília (UnB), Brasília, 2013, p. 29.

412 SARLET, Ingo Wolfgang. Notas sobre a dignidade da pessoa humana na jurisprudência do Supremo Tribunal Federal. In: SARMENTO, Daniel; SARLET, Ingo Wolfgang (Coord.). Direitos fundamentais no Supremo Tribunal Federal: balanço e crítica. Rio de Janeiro: Lumen luris, 2011, p. 52.

${ }^{413}$ Id., A eficácia dos direitos fundamentais: uma teoria geral dos direitos fundamentais na perspectiva constitucional. 10. ed. Porto Alegre: Livraria do Advogado Editora, 2011, p. 61.

414 Ibid., p. 61.

${ }^{415}$ Ibid., p. 61. 
medida em que o ideal democrático se encontre disseminado, ao mesmo tempo, na sociedade política e na sociedade civil $^{416}$. De outro lado, a institucionalização dos direitos fundamentais é:

(...) pressuposto, garantia e instrumento do princípio democrático de autodeterminação do povo por intermédio de cada indivíduo, mediante o reconhecimento do direito de igualdade (perante a lei e de oportunidades), de um espaço de liberdade real, bem como por meio da outorga do direito à participação (com liberdade e igualdade), na conformação da comunidade e do processo político, de tal sorte que a positivação e a garantia do efetivo exercício de direitos políticos (no sentido de direitos de participação e conformação do status político) podem ser considerados 0 fundamento funcional da ordem democrática e, neste sentido, parâmetro de sua legitimidade ${ }^{417}$.

Uma Constituição que estabelece direitos fundamentais de todas as dimensões, por conseguinte, responde às necessidade de uma sociedade hipercomplexa, na medida em que eles preservam a pluralidade de expectativas (essencial ao regime democrático) e configuram obstáculos à institucionalização de concepções totalitárias que, ao invés de incluir, promovem a exclusão de grupos variados da participação da vida social ${ }^{418}$.

É por isso que se pode afirmar que o Estado Constitucional contemporâneo, alinhando democracia e direitos fundamentais, representa um paradigma voltado para o pluralismo, que "busca promover a maior diversidade possível de concepções de bem como meio para a maximização da autonomia e da dignidade humanas", negando, para tanto, "exclusividade ou predomínio a todas as concepções concorrentes" ${ }^{\prime 19}$.

$E$, em assim sendo, o constitucionalismo, na difícil tarefa de definir a identidade do sujeito constitucional, não pode se esquivar da oposição entre o eu e o outro - tanto um outro externo à comunidade política organizada que se atribui uma Constituição quanto, principalmente, um outro interno ao próprio eu constitucional ${ }^{420}$.

${ }^{416}$ DELGADO, Maurício Godinho. Constituição da República, Estado Democrático de Direito e Direito do Trabalho. In: DELGADO, Maurício Godinho; DELGADO, Gabriela Neves. Constituição da República e direitos fundamentais. 3. ed. São Paulo: LTr, 2015, p. 42.

417 SARLET, Ingo Wolfgang. A eficácia dos direitos fundamentais: uma teoria geral dos direitos fundamentais na perspectiva constitucional. 10. ed. Porto Alegre: Livraria do Advogado Editora, 2011, p. 61.

${ }^{418}$ NEVES, Marcelo. A constitucionalização simbólica. 3. ed. São Paulo: Editora WMF Martins Fontes, 2011, p. 74-76.

${ }^{419}$ ROSENFELD, Michel. A identidade do sujeito constitucional. Tradução de Menelick de Carvalho Netto. Belo Horizonte: Mandamentos: 2003, p. 54.

${ }^{420}$ Conforme Rosenfeld, nos moldes da Fenomenologia de Hegel e da teoria psicanalítica, o confronto do eu com o outro é resultado da separação entre sujeito e objeto. Dessa relação, 
A composição desse conflito, na medida das possibilidades, é objetivo ínsito do Estado Democrático de Direito.

É por isso que não se sustenta a tese de que a identidade constitucional surge como produto de um constituinte totalmente autônomo e plenipotente, com poderes para, se assim desejar, negar reconhecimento às outras identidades relevantes de uma dada comunidade política (culturais, étnicas e religiosas, por exemplo). Isso porque, de um lado, por mais revolucionária que sejam as circunstâncias de sua origem, a identidade do sujeito constitucional deriva, em maior ou menor grau, da incorporação seletiva de elementos e identidades da tradição pré-constitucional que Ihe conferem sustentação. E, de outro lado, tanto quanto a tradição do passado, as condições materiais e identidades relevantes do presente e do futuro também impõem restrições ao processo de construção da identidade constitucional ${ }^{421}$.

O verdadeiro desafio do constituinte é a elaboração de uma Constituição aberta $^{422}$ capaz de se perpetuar no tempo, com eficácia normativa e social. Para tanto, deve se desincumbir do dever de estruturar, no Texto Constitucional, uma identidade suficientemente permeável à (re)elaboração, que transcenda a sua autoimagem para, na medida do possível, permitir que, no curso de sua vigência, o outro também possa se identificar com o sujeito constitucional. A articulação do passado, do presente e do futuro da comunidade política a que se dirige a Constituição é pressuposto, portanto, de sua própria manutenção ${ }^{423}$.

A identidade do sujeito constitucional precisa ser em alguma medida compartilhada e almejar preencher o hiato entre o eu e o outro ${ }^{424}$. Ela é, portanto, necessariamente fragmentária e incompleta. E deve assim permanecer, pois será o

o sujeito emerge como consciência de sua carência, pois define a si mesmo enquanto uma negação dos objetos de que necessita para satisfazer os seus desejos. É a partir dessa experiência de incompletude, do aprendizado de que a realização está além dos objetos, os quais suprem apenas momentaneamente o desejo, que o sujeito, para formar e firmar a sua identidade de sujeito, vai em busca de outros que o reconheçam e, assim, possam satisfazer o seu desejo de forma duradoura. Nesse passo, a busca pela consolidação da identidade importa, em alguma medida, a sujeição do eu ao outro (ROSENFELD, Michel. A identidade do sujeito constitucional. Tradução de Menelick de Carvalho Netto. Belo Horizonte: Mandamentos: 2003, p. 29-33).

${ }^{421}$ Ibid., p. 34-35.

422 Sobre o tema, consultar: CARVALHO NETTO, Menelick de; SCOTTI, Guilherme. Os direitos fundamentais e a (in)certerteza do Direito: a produtividade das tensões principiológicas e a superação do sistema de regras. Belo Horizonte: Fórum, 2011.

${ }^{423}$ ROSENFELD, op. cit., p. 86.

${ }^{424}$ Ibid., p. 36. 
discurso constitucional que se produz a partir de e voltado para a Constituição (como a legislação e a interpretação judicial) quem definirá o que é passível ou não de integração à identidade do sujeito constitucional. Nesse processo, a produção discursiva tem de observar, como parâmetros para a agregação seletiva de novos elementos à imagem do eu constitucional, a matriz normativa e principiológica estabelecida na Constituição. Caso se pretenda incluir elementos que desafiem a dignidade humana e os direitos fundamentais reconhecidos, por exemplo, a identidade constitucional será desnaturada, ao invés de se densificar e fortalecer ${ }^{425}$.

É por isso que o discurso constitucional, atuando na produção do próprio Direito, deve se ater a um princípio de coerência, como o da integridade, proposto por Dworkin, que mantenha a racionalidade do sistema ${ }^{426}$.

Com base na Teoria da Linguística, Rosenfeld sustenta que a elaboração do discurso constitucional, no processo incessante de construção da identidade constitucional, pode ser reconduzido a três tipos de operações básicas: a negação, a metáfora e a metonímia ${ }^{427}$.

Por meio da negação, define-se o eu constitucional, num primeiro momento, por aquilo que ele não é: pela rejeição de outras identidades extra e préconstitucionais. Todavia, o constitucionalismo não pode se realizar sobre um vazio, devendo encontrar algum amparo mínimo na história e na cultura da comunidade política. Nessa esteira, num segundo momento, passa-se à negação da negação: com vistas a construir uma identidade própria positiva, o sujeito constitucional ele retoma as identidades externas rechaçadas e, filtrando o seus elementos de acordo com o projeto constitucional e com os limites do constitucionalismo, as incorpora seletivamente ${ }^{428}$.

O discurso da metáfora, por sua vez, para forjar o eu constitucional, opera estabelecendo relações de similaridade, analogia e equivalência, em detrimento das divisões e das diferenciações. Os processos metafóricos, nesse sentido, se prestam ao alargamento do sentido e do campo de incidência das normas constitucionais,

\footnotetext{
${ }^{425}$ ROSENFELD, Michel. A identidade do sujeito constitucional. Tradução de Menelick de Carvalho Netto. Belo Horizonte: Mandamentos: 2003, p. 40-46.

${ }^{426}$ Acerca da concepção de Direito como integridade formulada por Dworkin, cf. DWORKIN, Ronald. O império do direito. 2. ed. São Paulo: Martins Fontes, 2007.

${ }^{427}$ Cf. ROSENFELD, op. cit.

${ }^{428}$ Ibid., p. 51-60.
} 
sobretudo dos direitos fundamentais, conduzindo a identidade do sujeito constitucional a níveis maiores de abstração ${ }^{429}$.

O instrumento da metonímia, em sentido contrário, estabelece relações de contiguidade e, bem assim, tende a aparar os contornos da identidade do sujeito constitucional através da contextualização. Logo, o discurso metonímico põe em evidência as diferenças e as especificidades concretas, para afunilar o sentido e o alcance das normas constitucionais. Mas ele também pode se revelar inclusivo, exatamente por se prestar ao reconhecimento do que é diferente e da pluralidade, propiciando abordagens jurídicas atentas às necessidades e às carências particulares de determinados segmentos sociais. Afinal, "a igualdade requer mais a proporcionalidade do que a simples similaridade de tratamento, é necessário contextualizar e levar determinadas diferenças em conta" ${ }^{430}$.

Na perspectiva proposta por Rosenfeld, a reprodução da ordem constitucional dentro de parâmetros coerentes e em consonância com as exigências do constitucionalismo contemporâneo, como a observância dos direitos fundamentais, depende da combinação desses três instrumentos discursivos, de modo a propiciar a inclusão das diferenças sem se esgarçar a identidade constitucional. Assim, "O melhor equilíbrio entre o self e o 'outro' que o sujeito constitucional pode esperar alcançar é aquele no qual o máximo possível de diferenças encontrem guarida na postura inclusiva em relação ao outro interno" ${ }^{431}$.

Nesse rumo, o caráter aberto da identidade constitucional à qual se reportam os direitos fundamentais os torna também um projeto necessariamente inacabado, um "processo permanente, e portanto mutável, de afirmação da cidadania"432

\subsection{Igualdade e diferença: o enfrentamento à toda forma de discriminação como objetivo do Estado Democrático de Direito}

\footnotetext{
${ }^{429}$ ROSENFELD, Michel. A identidade do sujeito constitucional. Tradução de Menelick de Carvalho Netto. Belo Horizonte: Mandamentos: 2003, p. 61-67.

${ }^{430}$ Ibid., p. 67-74.

${ }^{431}$ Ibid., p. 114.

432 CARVALHO NETTO, Menelick de. A Hermenêutica Constitucional e os desafios postos aos Direitos Constitucionais. In: José Adécio Leite Sampaio. (Org.). Jurisdição Constitucional e Direitos Fundamentais. Belo Horizonte: Del Rey, 2003, p. 145.
} 
Um dos desdobramentos mais evidentes da dignidade humana, como pilar fundamental do constitucionalismo, é, decerto, o reconhecimento do direito à igualdade.

A Declaração Universal dos Direitos Humanos dispõe, em seu art. $1^{\circ}$, que "Todas as pessoas nascem livres e iguais em dignidade e direitos. São dotadas de razão e consciência e devem agir em relação umas às outras com espírito de fraternidade" ${ }^{433}$. Em direção similar, a Constituição brasileira de 1988, em seu art. 5, estabelece que "Todos são iguais perante a lei, sem distinção de qualquer natureza, garantindo-se aos brasileiros e aos estrangeiros residentes no País a inviolabilidade do direito à igualdade".

Em seu conceito formal (igualdade perante a lei), igualdade significa a universalização do direito em face da figura abstrata do sujeito de direito. Assim concebido, o direito individual à igualdade é uma herança das Revoluções Liberais que consolidaram o Estado de Direito, destinando-se a eliminar disparidades, no plano jurídico, propiciadas por uma antiga estrutura social dividida em estamentos. Ela requer, portanto, uma aplicação uniforme do direito, sem distinções quanto aqueles sobre os quais incidirão os seus efeitos ${ }^{434}$.

A perspectiva formal da igualdade segue amparada pelos paradigmas jurídicos hodiernos, como um direito humano e fundamental de primeira dimensão, que evoca, no plano abstrato do discurso metafórico, o componente mais elementar da ideia de dignidade da pessoa humana: todas as pessoas são dotadas de um igual valor, que decorre da própria condição humana, e estão sujeitas, neste passo, à igual incidência das normas jurídicas.

Se essa assertiva é nuclear para o Direito contemporâneo, ela é, porém, insuficiente e reclama complementação, a partir de uma perspectiva substancial de igualdade, que se abra à possibilidade de diferenciação na disciplina jurídica em face de situações que, no plano fático, não sejam equivalentes.

Isso porque, a um, a ideia de justiça que subjaz ao constitucionalismo é composta por exigências de redistribuição e reconhecimento. Requer, então, um esforço metonímico de contextualização, por parte do discurso jurídico, que leve em

\footnotetext{
${ }^{433}$ ONU. Declaração Universal dos Direitos Humanos, Resolução 217 A (III) da Assembleia Geral das Nações Unidas, 1948.

${ }^{434}$ RIOS, Roger Raupp. O princípio da igualdade e a discriminação por orientação sexual: a homossexualidade no direito brasileiro e norte-americano. São Paulo: Editora Revista dos Tribunais, 2002, p. 33-43.
} 
consideração a precariedade diferenciada a que os grupos e indivíduos estão expostos, tanto em termos de acesso a recursos materiais quanto em termos de inclusão nos padrões histórico-culturais de reconhecimento ${ }^{435}$.

Noutro giro, como já se ventilou, o pluralismo constitui uma necessidade e um objetivo do próprio paradigma de Estado Democrático de Direito, o que requer a instituição de mecanismos que evitem a infiltração, no Direito, de concepções existenciais totalizantes. Quanto ao mais, o pluralismo é um estímulo à "admissão, de respeito e proteção, a projetos de vida distintos daqueles considerados como padrão pela maioria da sociedade"436.

O Estado Constitucional contemporâneo, em assim sendo, não pode restringir a tutela jurídica a uma concepção de sujeito de direito altamente abstrata e descolada da realidade, pois, se assim o fizer, deixa de se revelar como solução factível para a regulação do comportamento humano. O Direito, por conseguinte, precisa ter em vista as diferenças cumprir sua dimensão de concretização da justiça social.

De acordo com Ferrajoli, há quatro arranjos jurídicos possíveis quando se trata de lidar com as diferenças existentes numa dada comunidade política. O primeiro deles consiste na completa indiferença jurídica às diferenças concretas. Próximo à ideia hobbesiana de estado de natureza, as diferenças são ignoradas de forma a valorizar a mais ampla liberdade individual. Mas o conflito entre o eu e o outro, nessas circunstâncias, fica sujeito somente às relações de força. O segundo é o modelo de diferenciação jurídica das diferenças, pelo qual o Direito passa a atribuir valores positivos ou negativos às identidades, hierarquizando-as num sistema marcado por privilégios e prejuízos. É um modelo que admite discriminações, portanto. Já o terceiro modelo, de homologação jurídica das diferenças, próprio do Estado Liberal de Direito, embora reconheça a existência da diferença, acaba por anulá-la ao prestigiar, como ideal de justiça, uma concepção formal e abstrata da igualdade ${ }^{437}$.

O quarto arranjo é o da igual valoração jurídica das diferenças, uma abordagem que complementa a igualdade formal, incorporando o viés inclusivo do

\footnotetext{
${ }^{435}$ FRASER, Nancy. Reconhecimento sem ética?. Lua Nova, São Paulo, n. 70, p. 101-138, 2007, p. 109-110.

${ }^{436}$ CRUZ, Álvaro Ricardo de Souza. O direito à diferença. As ações afirmativas como mecanismo de inclusão social de mulheres, negros, homossexuais e pessoas portadoras de deficiência. $2^{\mathrm{a}}$ edição. Belo Horizonte: Del Rey, 2005, p. 79.

${ }^{437}$ FERRAJOLI, Luigi. Igualdad y diferencia. Igualdad y no discriminación: el reto de la diversidad. Quito: Danilo Caicedo Tapia e Angélica Porras Velasco (editores), 2010, p. 156159.
} 
Estado Democrático de Direito. Ao invés de apenas ignorar, tolerar ou encobrir as diferenças sob um manto de igualdade ficta, esse modelo exige a afirmação e o reconhecimento jurídico da diversidade, como condição para o livre desenvolvimento da personalidade. Tratando todas as identidades como detentoras de igual valor na ordem constitucional, essa vertente rechaça discriminações e reclama pela adequação da tutela jurídica às necessidades específicas de cada caso ${ }^{438}$.

Trilhando um caminho similar, Piovesan sustenta haver três dimensões nas quais se desdobra o direito à igualdade. Primeiramente, em sua vertente liberal originária, cumpre falar na igualdade formal, isto é, na proposição segundo a qual o Direito deve tratar a todos igualmente, sem privilégios ou prejuízos, pois todo ser humano é igual perante a lei. Quando se volta, porém, à vertente substancial da igualdade, centrada nas discriminações que obstam a interação paritária dos sujeitos na vida social, há uma nova ramificação, que espelha a concepção de justiça traçada por Fraser. De um lado, o direito material à igualdade implica redistribuição, isto é, a necessidade de se minimizarem as disparidades socioeconômicas existentes. Mas, de outro lado, o direito material à igualdade demanda o reconhecimento das diferentes identidades e o respeito recíproco entre os indivíduos ${ }^{439}$.

Em sua acepção material, a isonomia não se contenta, pois, com uma igualdade perante a lei. Ela vai além e requer a institucionalização de uma igualdade na $\operatorname{lei}^{440}$.

Uma segunda derivação evidente do princípio da dignidade da pessoa humana é, no mesmo passo, o direito à liberdade. Ele emana da ideia de que o valor distintivo de todo indivíduo, enquanto humano, resulta de sua condição de ser racional, potencialmente capaz de se autodeterminar, traçando os caminhos para sua autorrealização.

A liberdade, dessa forma, enquanto poder de decidir, dilui-se pelo textos constitucionais $^{441}$. Ser livre comporta múltiplos significados. Pode-se falar em

\footnotetext{
${ }^{438}$ FERRAJOLI, Luigi. Igualdad y diferencia. Igualdad y no discriminación: el reto de la diversidad. Quito: Danilo Caicedo Tapia e Angélica Porras Velasco (editores), 2010, p. 159.

439 PIOVESAN, Flávia. Igualdade, diferença e direitos humanos: perspectivas global e regional. In: SARMENTO, Daniel; IKAWA, Daniela; PIOVESAN, Flávia (Coord.). Igualdade, diferença e direitos humanos. Rio de Janeiro: Editora Lumen Juris, 2010, p. 51 e 52.

${ }^{440}$ RIOS, Roger Raupp. O princípio da igualdade e a discriminação por orientação sexual: a homossexualidade no direito brasileiro e norte-americano. São Paulo: Editora Revista dos Tribunais, 2002, p. 44.

${ }^{441}$ São exemplos de liberdades fundamentais, os direitos previstos nos artigos $3^{\circ}$, I; e $5^{\circ}$, caput, IV, VI, IX, XIII, XV, XVI e XVII, da Constituição Federal de 1988.
} 
liberdade intelectual, artística, de crença, expressão, reunião, associação, exercício de trabalho, ofício ou profissão, e (por que não?) vivência do afeto e da sexualidade.

O direito fundamental à liberdade pressiona o Estado não somente a se abster de intervir na esfera da autonomia privada, possibilitando que se exerça o poder de escolha de forma desembaraçada, mas, também, sob um viés prestacional, a fornecer as condições para que as escolhas existenciais possam se realizar, mesmo que se afastem dos padrões de vida socialmente legitimados ${ }^{442}$.

Nesse rumo da conjugação dos direitos fundamentais à igualdade e à liberdade extrai-se que "as pessoas e os grupos sociais têm o direito a ser iguais quando a diferença os inferioriza, e o direito a ser diferentes quando a igualdade os descaracteriza" 443 .

É por isso que as sociedades democráticas contemporâneas, ancorando-se em um princípio inclusivo de valorização do pluralismo e de respeito à alteridade, tomam o combate à discriminação como uma função de relevo para a qual o Direito deve se voltar, sempre se aperfeiçoando ${ }^{444}$.

Discriminar significa perceber diferenças, distinguir, discernir, especificar, separar $^{445}$. Mas nem toda separação ou distinção, tomando por base diferenças percebidas entre pessoas, traz em si um sentido negativo - apenas aquela que sem justificativa aceitável, implica prejuízos a alguém, criando desigualdades ${ }^{446}$. É esta a discriminação, não raro uma manifestação de preconceitos ${ }^{447}$, que interessa ao Direito e para a qual se deve atentar na elaboração de mecanismos jurídicos que permitam o seu enfrentamento.

\footnotetext{
${ }^{442}$ BARROSO, Luís Roberto. Diferentes, mas iguais: o reconhecimento jurídico das relações homoafetivas no Brasil. In: SARMENTO, Daniel; IKAWA, Daniela; PIOVESAN, Flávia (Coord.). Igualdade, diferença e direitos humanos. Rio de Janeiro: Editora Lumen Juris, 2010, p. 678.

${ }^{443}$ SANTOS, Boaventura de Souza. As tensões da modernidade. Texto apresentado no Fórum Social Mundial, Porto Alegre, 2001. Disponível em: <http://www.susepe.rs.gov.br/upload/1325792284_As\%20tens\%C3\%B5es\%20da\%20Moder nidade $\% 20-\% 20$ Boaventura\%20de\%20Sousa\%20Santos.pdf>. Acesso em: 06/04/2016.

${ }^{444}$ DELGADO, Maurício Godinho. Proteções contra discriminação na relação de emprego. In: RENAULT, Luiz Otávio Linhares; VIANA, Márcio Túlio; CANTELLI, Paula Oliveira (coord.). Discriminação. 2. ed. São Paulo: LTr, 2010, p. 108.

${ }^{445}$ HOUAISS, Antônio. Grande Dicionário Houaiss da Língua Portuguesa. Disponível em: $<$ http://houaiss.uol.com.br/>. Acesso em 06/04/2016.

${ }^{446}$ SOUTO MAIOR, Jorge Luiz. O direito do trabalho e as diversas formas de discriminação.

Revista do Tribunal Superior do Trabalho, Brasília, vol. 68, $n^{\circ} 2$, abr./jun. 2002, p. 97.

${ }^{447}$ Cf. Capítulo 1 desta pesquisa, sobre o tema dos preconceitos.
} 
Uma das estratégias mais comuns, com esse intento, é a positivação de critérios proibidos de diferenciação ${ }^{448}$. Tal estratégia leva em conta a construção histórica de preconceitos em torno de determinadas identidades ou atributos, como gênero, cor, ou condição de pessoa deficiente, o que implica uma tendência a que esses parâmetros sejam utilizados para fins de justificar ou dar origem a desigualdades socioeconômicas ou a marginalização de indivíduos ${ }^{449}$ no exercício pleno da cidadania ${ }^{450}$.

Isso não significa dizer que a dispensa de tratamento díspar, mesmo com base nesses critérios, seja sempre uma conduta anti-isonômica. A proibição não é, portanto, absoluta ${ }^{451}$.

Melo adverte que não se deve buscar na própria característica distintiva, isoladamente, a transgressão à isonomia e, consequentemente, à dignidade da pessoa humana - ainda que se trate de um critério de diferenciação suspeito para o Direito, pelo preconceito potencial que o seu uso encerra. Cumpre investigar, também, se o critério em questão guarda um vínculo de correlação lógica com a diferença de tratamento pretendida e, além disso, se este liame e os fins aos quais visa encontram amparo nos valores e interesses promovidos pela ordem constitucional ${ }^{452}$.

\footnotetext{
448 Por meio da expressão "critério proibidos de diferenciação", Rios alude à opção constitucional ou legislativa de vedar o uso de determinados atributos individuais ou coletivos como parâmetro para se dispensar tratamento diferenciado a pessoa ou grupo de pessoas, em comparação com as demais. Sobre o tema, consultar: RIOS, Roger Raupp. O principio da igualdade e a discriminação por orientação sexual: a homossexualidade no direito brasileiro e norte-americano. São Paulo: Editora Revista dos Tribunais, 2002; e Id., Direito da Antidiscriminação, sexo, sexualidade e gênero: a compreensão da proibição constitucional de discriminação por motivo de sexo. In: SARMENTO, Daniel; IKAWA, Daniela; PIOVESAN, Flávia (Coord.). Igualdade, diferença e direitos humanos. Rio de Janeiro: Editora Lumen Juris, 2010.

449 Id., op. cit., 2002, p. 44.

${ }^{450}$ Segundo Delgado, a cidadania, "em sentido amplo e contemporâneo, típica de um Estado Democrático de Direito, pode ser conceituada como a aptidão de indivíduo em adquirir direitos, prerrogativas e proteções da ordem jurídica, aptos a qualificá-lo como igual a seus semelhantes, no contexto da sociedade local, regional ou internacional". DELGADO, Gabriela Neves. Direito fundamental ao trabalho digno. 2. ed. São Paulo: LTr, 2015, p. 51.

${ }^{451}$ RIOS, op. cit., 2002, p. 44.

${ }^{452}$ MELLO, Celso Antônio Bandeira de. O conteúdo jurídico do princípio da igualdade. 3.

Ed. São Paulo: Malheiros Editores, 2009
} 
Deve haver justificativa razoável, nunca arbitrária, à diferenciação proposta ${ }^{453}$. $E$, por conseguinte, àquele que dispensa tratamento desigual impõe-se o ônus argumentativo de sustentar a licitude da prática ${ }^{454}$.

Esse mecanismo de efetivação da tutela antidiscriminatória é usual em tratados e convenções internacionais de direitos humanos. Dele se valem, por exemplo, o Pacto Internacional sobre Direitos Civis e Políticos e o Pacto Internacional sobre Direitos Econômicos, Sociais e Culturais, de 1966, e a Convenção Americana de Direitos Humanos (Pacto de San José da Costa Rica), de 1969.

O uso de critérios proibidos de diferenciação foi um caminho adotado igualmente pelo constituinte brasileiro de 1988, ao lado das cláusulas gerais de vedação às distinções de qualquer natureza (art. $5^{\circ}$, caput). É o que se verifica da redação do art. $3^{\circ}$, IV, da Constituição da República:

Art. $3^{\circ}$ Constituem objetivos fundamentais da República Federativa do Brasil:

IV - promover o bem de todos, sem preconceitos de origem, raça, sexo, cor, idade e quaisquer outras formas de discriminação ${ }^{455}$.

É importante perceber que, embora o texto original da Constituição já englobasse uma proibição às práticas discriminatórias, como objetivo fundamental da República, ele não estabelecia um conceito de discriminação.

Não que, no conjunto do ordenamento jurídico brasileiro, não se dispusesse de tal definição. Tratados e convenções internacionais de direitos humanos ratificados pelo Brasil, é bem verdade, já a forneciam em nível supralegal ${ }^{456}$, a exemplo da

${ }^{453}$ ALEXY, Robert. Teoria de los Derechos Fundamentales. Madri: Centro de Estúdios Políticos y Constitucionales, 2001, p. 398-402.

${ }^{454}$ RIOS, Roger Raupp. O principio da igualdade e a discriminação por orientação sexual: a homossexualidade no direito brasileiro e norte-americano. São Paulo: Editora Revista dos Tribunais, 2002, p. 54.

${ }^{455}$ BRASIL. Constituição da República Federativa do Brasil. D.O.U. 191-A, 05/10/1988, p. 1.

456 O Supremo Tribunal Federal entende que, após a promulgação da EC 45/2004, os diplomas internacionais sobre direitos humanos ratificados pelo Brasil são incorporados ao ordenamento pátrio em duas posições hierárquicas distintas, a depender do procedimento adotado em sua aprovação. Caso observem o rito previsto no art. $5^{\circ}, \S 3^{\circ}$, da Constrição, ingressam no Direito Brasileiro com força de emenda constitucional, passando inclusive a parâmetro de exercício de controle de constitucionalidade. Se, pelo contrário, não se adotar o rito mencionado, sua assimilação pelo ordenamento, em atenção ao disposto no art. $5^{\circ}$, § $2^{\circ}$, se faz com status supralegal: embora hierarquicamente inferiores à Constituição Federal, situam-se acima das leis infraconstitucionais, podendo paralisar-lhes os efeitos no que forem contrárias a seus princípios e regras. Nesse sentido, cf. BRASIL. Supremo Tribunal Federal. RE 466343, Tribunal Pleno, julgamento em 3.12.2008, DJe de 5.6.2009. 
Convenção sobre a Eliminação de Todas as Formas de Discriminação Contra a Mulher, de 1979, e da Convenção Internacional sobre a Eliminação de todas as Formas de Discriminação Racial, de 1966.

Sem embargo, a ratificação da Convenção Internacional sobre os Direitos das Pessoas com Deficiência e seu Protocolo Facultativo, em 2009, observando o procedimento instituído no art. $5^{\circ}, \S 3^{\circ}$, da Constituição, fez com que o Texto Constitucional de 1988 passasse a dispor de uma concepção própria para a discriminação, definindo, assim, os contornos da vedação geral inscrita no art $3^{\circ}, \mathrm{IV}^{457}$. Nos termos do art. $2^{\circ}$ da Convenção, reputa-se discriminação:

(...) qualquer diferenciação, exclusão ou restrição (...), com o propósito ou efeito de impedir ou impossibilitar o reconhecimento, o desfrute ou o exercício, em igualdade de oportunidades com as demais pessoas, de todos os direitos humanos e liberdades fundamentais nos âmbitos político, econômico, social, cultural, civil ou qualquer outro ${ }^{458}$.

Duas importantes conclusões se extraem da alusão a que o Texto Constitucional faz às diferenciações, exclusões ou restrições, com o propósito ou efeito de impedir o reconhecimento, o desfrute ou o gozo de direitos fundamentais em igualdade de oportunidades com as demais pessoas.

Em primeiro lugar, da expressão "com o propósito ou efeito" dessume-se que a Constituição Federal de 1988, sublinhando ser indiferente à intenção do agente para que se configure a discriminação interditada, rechaça condutas discriminatórias tanto diretas quanto indiretas.

A discriminação direta se consuma quando a violação a direitos é fruto de conduta intencional que visa causar prejuízo ou negar reconhecimento a outrem. A discriminação indireta, por outro lado, ocorre quando essa mesma transgressão a direitos é resultado de medidas despidas dessa intencionalidade lesiva e que se apresentam como neutras, mas tem o resultado prático de impor prejuízos a sujeitos e grupos sociais específicos ${ }^{459}$.

\footnotetext{
${ }^{457}$ RIOS, Roger Raupp; SOUZA, Luiz Gustavo Oliveira de; SPONCHIADO, Tobias. Notícias de homofobia e proteção jurídica antidiscriminatória. In: DINIZ, Debora; OLIVEIRA, Rosana Medeiros de. (Orgs.). Notícias de homofobia no Brasil. Brasília: Letras Livres, 2014, p. 161. ${ }^{458}$ BRASIL. Decreto 6.949 (Promulga a Convenção Internacional sobre os Direitos das Pessoas com Deficiência e seu Protocolo Facultativo). Diário Oficial da União, 26/08/2009, p. 3.

${ }^{459}$ RIOS; SOUZA; SPONCHIADO; op. cit., p. 162-163.
} 
Em segundo lugar, ao enunciar o efeito prático das diferenciações, exclusões e restrições, o Texto Constitucional deixa claro que não são todas as diferenças de tratamento, ainda que baseadas em critérios suspeitos, que se incluem no âmbito de incidência da vedação às discriminações, mas tão somente aquelas condutas que implicarem negativa de reconhecimento, desfrute e exercício de direitos fundamentais em igualdade de oportunidade com as demais pessoas.

A inserção da discriminação no âmbito das matérias sujeitas à regulação pelo Direito se opera, pois, com a finalidade de prevenir e sancionar as transgressões ao princípio da isonomia em sua vertente substancial ${ }^{460}$.

Não se trata, valer repisar, de impedir diferenças de tratamento lícitas, justificáveis racionalmente pela legitimidade dos fins a que visam, em conformidade com os princípios, valores e objetivos encampados pela Constituição - é a forma como, ao fim e ao cabo, se concretiza o princípio da igualdade em sua perspectiva redistributiva e as ações afirmativas ${ }^{461}$.

\subsection{A orientação sexual como critério de diferenciação proibido pelo ordenamento jurídico brasileiro}

Em que pese a proibição instituída pelos artigos $5^{\circ}$ e $3^{\circ}, \mathrm{IV}$, quando aborda 0 tema da discriminação, o Texto Constitucional brasileiro não menciona orientação sexual. Cumpre questionar se esse atributo (e, em especial, a homossexualidade) pode ser compreendido como um critério de diferenciação proibido, à luz da Constituição Federal de 1988 e dos tratados e convenções internacionais dos quais o Brasil é signatário, atraindo, desse modo, a disciplina jurídica estruturada pelo Direito da Antidiscriminação.

Consoante já se frisou, o contato e o desejo sexual entre pessoas do mesmo sexo, ao longo da história, deu base à manifestação de preconceitos sob as roupagens mais diversas: da condenação religiosa à criminalização, da falta moral à abordagem psicopatológica. Atualmente, em meio a uma luta por reconhecimento ainda em curso, vem crescendo a adesão tanto ao entendimento de que a

\footnotetext{
${ }^{460}$ RIOS, Roger Raupp. O conceito de homofobia na perspectiva dos direitos humanos e no contexto dos estudos sobre preconceito e discriminação. In: POCAHY, Fernando. (Org.). Rompendo o silêncio: homofobia e heterossexismo na sociedade. Porto Alegre: Nuances, 2007, p. 38.

461 Ibid., p. 38.
} 
homossexualidade constitui um aspecto neutro da identidade, nem positivo nem negativo em si mesmo, quanto ao de que as próprias identidades sexuais, binária e hierarquicamente organizadas, não passam de construções sociais reproduzidas historicamente, por meio da institucionalização de papéis culturalmente definidos ${ }^{462}$.

Nessa direção seguiu um grupo de especialistas em direitos humanos, composto por membros de diversos países, quando formulou os Princípios de Yogyakarta, um conjunto de diretrizes acerca da aplicação das normas internacionais de direitos humanos, em matéria de orientação sexual e identidade de gênero. Embora despido de normatividade, esse documento, ratificado pela Comissão Internacional de Juristas, vem servindo de referência para organismos internacionais, como o Comitê de Direitos Econômicos, Sociais e Culturais da $\mathrm{ONU}^{463}$. De acordo com os referidos Princípios, a homossexualidade pode ser definida como a "capacidade de cada pessoa para sentir uma atração emocional, sexual e emocional profunda para indivíduos (...) do mesmo gênero (...), bem como a capacidade de manter relações íntimas e sexuais com essas pessoas" ${ }^{\prime 64}$.

Nesse sentido, a homossexualidade denota o mero direcionamento da pulsão sexual humana a pessoas do mesmo sexo, tão natural quanto a atração majoritariamente verificada entre pessoas de sexo diferente. Isoladamente, essa característica não torna uma pessoa melhor ou pior, superior ou inferior a nenhuma outra - e tampouco a heterossexualidade se presta a essa função.

Consubstanciando, a homossexualidade, uma das formas pelas quais uma pessoa pode, sexual e afetivamente, se realizar no curso de sua existência, ela se situa no âmbito de autodeterminação do indivíduo.

Por conseguinte, dado o elo existente entre vivência da sexualidade e projeto de vida, a orientação sexual constitui um desdobramento da dignidade humana que reclama proteção jurídica. Negar o reconhecimento, o exercício ou o gozo de direitos como forma de inferiorizar o outro, expô-lo e humilhá-lo, tão somente por conta de um estigma relacionado a sua orientação sexual significa despi-lo do valor que lhe é

\footnotetext{
${ }^{462}$ RIOS, Roger Raupp. O principio da igualdade e a discriminação por orientação sexual: a homossexualidade no direito brasileiro e norte-americano. São Paulo: Editora Revista dos Tribunais, 2002, p. 116-117

${ }^{463}$ A esse respeito, cf. E/C.12/GC/20 (Não discriminação em direitos econômicos, sociais e culturais - Comentário Geral n²0), 2009

${ }^{464}$ Princípios de Yogyakarta: Princípios sobre a aplicação da legislação internacional de direitos humanos em relação à orientação sexual e identidade de gênero. Disponível em: <http://www.yogyakartaprinciples.org/principles_en.pdf>. Acesso em 05/04/2016
} 
inerente e negá-lo enquanto parceiro de interação, atacando um aspecto íntimo e constitutivo de sua personalidade, bem como erigindo obstáculos à sua autorrealização.

Se a dignidade da pessoa humana é, em alguma medida, fundamento dos direitos e garantias assegurados pelo Texto Constitucional e igualmente fonte por meio da qual se podem deduzir outros direitos fundamentais, ainda que não explicitamente positivados mas decorrentes do regime e dos princípios encampados pela Constituição (art. $\left.5^{\circ}, \S 2^{\circ}\right)^{465}$, pode-se facilmente extrair do sistema constitucional um direito fundamental à livre orientação sexual ${ }^{466}$.

Para Fachin, essa posição jusfundamental é nada mais que "um prolongamento de direitos da personalidade imprescindíveis para a construção de uma sociedade que se quer livre, justa e solidária" 467 .

O vínculo necessário entre possibilidade de vivência da orientação sexual e garantia da dignidade da pessoa humana já foi, aliás, traçado pelo Supremo Tribunal Federal, por ocasião do julgamento conjunto da ADPF 132 e da ADI 4.277:

Óbvio que, nessa altaneira posição de direito fundamental e bem de personalidade, a preferência sexual se põe como direta emanação do princípio da "dignidade da pessoa humana" (inciso III do art. $1^{\circ} \mathrm{da} C \mathrm{CF}$ ), e, assim, poderoso fator de afirmação e elevação pessoal ${ }^{468}$.

Por conseguinte, é seguro afirmar que se valer da homossexualidade de uma pessoa para lhe negar "tratamento compatível com o padrão jurídico assentado para a situação concreta por ela vivenciada"469 é conduta que se amolda ao conceito constitucionalizado de discriminação, que informa o rol de vedações do art. $3^{\circ}$, IV, da Constituição de 1988.

Diante dessas considerações, se pode suscitar, sem dificuldades, o enquadramento da homossexualidade na cláusula aberta dos critérios proibidos de

\footnotetext{
${ }^{465}$ SARLET, Ingo Wolfgang. Notas sobre a dignidade da pessoa humana na jurisprudência do Supremo Tribunal Federal. In: SARMENTO, Daniel; SARLET, Ingo Wolfgang (Coord.). Direitos fundamentais no Supremo Tribunal Federal: balanço e crítica. Rio de Janeiro: Lumen luris, 2011, p. 52.

${ }^{466}$ Id., Dignidade da pessoa humana e direitos fundamentais na Constituição Federal de 1988. 9. ed. rev. e atual. Porto Alegre: Livraria do Advogado Editora, 2011, p. 127.

${ }^{467}$ FACHIN, Luiz Edson. Direito de família: elementos críticos à luz do novo código civil brasileiro. 2. ed. Rio de Janeiro: Renovar, 2003, p. 121.

${ }_{468}$ BRASIL. Supremo Tribunal Federal. ADPF 132, Relator(a): Min. AYRES BRITTO, Tribunal Pleno, julgado em 05/05/2011, DJe-198 DIVULG 13-10-2011 PUBLIC 14-10-2011

${ }^{469}$ DELGADO, Maurício Godinho. Proteções contra discriminação na relação de emprego. In: RENAULT, Luiz Otávio Linhares; VIANA, Márcio Túlio; CANTELLI, Paula Oliveira (coord.). Discriminação. 2. ed. São Paulo: LTr, 2010, p. 108.
} 
discrímen prevista pela Constituição Federal, em seu art. $3^{\circ}$, IV, in fine, e por tratados internacionais de direitos humanos, como o Pacto Internacional sobre Direitos Econômicos, Sociais e Culturais, em seu art. $2^{\circ}$, por exemplo.

Mesmo nos diplomas em que essa abertura é omitida, os critérios proibidos de diferenciação neles explicitamente enunciados, por força da interpretação conforme a Constituição, devem ser compreendidos como meramente exemplificativos. Diante da vocação expansiva e inclusiva do princípio da dignidade da pessoa humana e da natureza mutável dos padrões de reconhecimento, as hipóteses arroladas, materializando experiências históricas para com os preconceitos, não impedem que sejam considerados outros critérios no curso do tempo, cuja proibição serviria igualmente ao propósito de eliminar discriminações arbitrárias ${ }^{470}$.

Opinião similar foi externada pelo Comitê incumbido por zelar pela aplicação do Pacto Internacional sobre os Direitos Econômicos, Sociais e Culturais, no que tange ao compromisso dos Estados signatários de respeitar e garantir a todos os indivíduos sujeitos a sua jurisdição os direitos ali reconhecidos, sem discriminação:

"Outro status", tal como reconhecido no artigo $2^{\circ}$, parágrafo $2^{\circ}$, inclui a orientação sexual. Os Estados partes devem assegurar que a orientação sexual de uma pessoa não é um obstáculo para a concretização dos direitos previstos no Pacto $(. . .)^{471}$.

Não obstante, uma outra corrente propõe uma abordagem alternativa, a partir da releitura da categoria proibida "sexo", já incorporada pelas normas constitucionais e internacionais de direitos humanos, expandindo, desse modo, a sua abrangência, em face do princípio e do direito fundamental à não discriminação, para alcançar também a discriminação por orientação sexual. Afinal, como anota Canotilho:

(...) à norma constitucional deve ser atribuído o sentido que maior eficácia lhe dê. É um princípio operativo em relação a todas e quaisquer normas constitucionais, e embora a sua origem esteja ligada à tese da actualidade das normas programáticas (Thoma), é hoje sobretudo invocado no âmbito dos direitos fundamentais (no caso de dúvidas deve preferir-se a interpretação que reconheça maior eficácia aos direitos fundamentais $)^{472}$.

\footnotetext{
${ }^{470}$ RIOS, Roger Raupp. O principio da igualdade e a discriminação por orientação sexual: a homossexualidade no direito brasileiro e norte-americano. São Paulo: Editora Revista dos Tribunais, 2002, p. 133.

${ }^{471}$ ONU (Comitê sobre Direitos Econômicos, Sociais e Culturais - Conselho Econômico e Social. E/C.12/GC/20 (Não discriminação em direitos econômicos, sociais e culturais Comentário Geral $\mathbf{n}^{\circ}$ 20), 2009.

472 CANOTILHO, J. J. Gomes. Direito constitucional e teoria da constituição. 7. ed. Coimbra: Almedina, 2003, p. 1224.
} 
Isso porque, mesmo sob o pressuposto de que a cláusula em questão, em sua gênese, é endereçada às desigualdades existentes entre homens e mulheres, não se sustenta a tese de que as diferenças que ela visa a combater são fruto da diversidade sexual meramente biológica. Por óbvio, o que se tem em mira são padrões culturalmente construídos, que vinculam o sexo de nascimento a expectativas normativas, condensadas em papéis de gênero, que justificam o tratamento díspar a homens e mulheres. A discriminação por sexo, nesse sentido, é uma discriminação por gênero e, logo, socialmente estruturada ${ }^{473}$.

Mas a discriminação por orientação sexual, observa Rios, é também produto desse regime social sexuado que institui formas legítimas e ilegítimas do uso que um indivíduo pode fazer de seu sexo. A ideia de orientação sexual é relacional, pois se esvazia por completo sem a referência ao sexo do indivíduo de onde parte a pulsão sexual e daquele outro ao qual ela se dirige. É dizer, discriminar alguém por sua homossexualidade implicar valer-se, como critério para esse tratamento indigno, da experiência deste indivíduo com a sua função sexual ${ }^{474}$.

Aderindo a esta posição, Costa sustenta que:

(...) a proibição de discriminação por motivo de sexo é estendida à questão da orientação sexual. Em ambos, a esfera da sexualidade está presente. Na questão da exclusão em razão da orientação sexual, o seu propulsor encontra-se justamente no sexo da pessoa para quem é dirigido o desejo sexual da vítima da discriminação. Assim sendo, a exclusão em razão da orientação sexual seria uma espécie do gênero que veda a discriminação por motivo de sexo ${ }^{475}$.

Igualmente, o Comitê de Direitos Humanos da ONU, no caso Toonen $v$. Austrália ${ }^{476}$, ao interpretar as disposições antidiscriminação constantes do Pacto Internacional de Direitos Civis e Políticos, se inclinou nesse sentido, consignando que:

O Estado parte buscou a orientação do Comitê quanto ao fato de a orientação sexual poder ser considerada " Outra situação", para os fins do artigo 26 [do Pacto Internacional de Direitos Civis e Políticos].

\footnotetext{
${ }^{473}$ RIOS, Roger Raupp. O principio da igualdade e a discriminação por orientação sexual: a homossexualidade no direito brasileiro e norte-americano. São Paulo: Editora Revista dos Tribunais, 2002, p. 133

${ }^{474}$ Ibid., p. 133

${ }^{475}$ COSTA, Ana Maria Machado da. A discriminação por orientação sexual no trabalho aspectos legais. In: POCAHY, Fernando. (Org.). Rompendo o silêncio: homofobia e heterossexismo na sociedade. Porto Alegre: Nuances, 2007, p. 95.

${ }^{476}$ No caso Toonen v. Austrália, um cidadão da Tasmânia levou ao Comitê uma reclamação de direitos humanos, na qual sustentava que os dispositivos do Código Penal da Tasmânia que criminalizavam o sexo consensual entre homens adultos seriam incompatíveis com o direito à privacidade, assegurado pelo art. 17 do Pacto Internacional de Direitos Civis e Políticos. Consultar: ONU. CCPR/C/50/D/488/1992 (Toonen v. Australia), 1994.
} 
A mesma questão pode emergir dos termos do artigo $2^{\circ}$, parágrafo $1^{\circ}$, do Pacto. A Comissão reserva-se a notar, no entanto, que, em sua opinião, a referência ao "sexo " nos artigos $2^{\circ}, n^{\circ} 1$, e 26 , deve ser tomado como incluindo a orientação sexual ${ }^{477}$.

Em suma, a despeito da ausência de referência explícita à orientação sexual na Constituição de 1988, como critério proibido de diferenciação, não há empecilho, mas sim um estímulo constitucional inclusivo para que se deduza a proibição jurídica também às práticas discriminatórias assim motivadas - seja no âmbito da cláusula de abertura ou como componente do critério "sexo".

Entretanto, é preciso considerar todo o sistema normativo que vem se estruturando em torno da vedação geral às discriminações, inscrita nos artigos $3^{\circ}, I V$, e $5^{\circ}$ do Texto Constitucional, o chamado Direito da Antidiscriminação, como sustenta Rios $^{478}$, para se ter noção da verdadeira amplitude alcançada por esta diretriz, no ordenamento jurídico brasileiro.

Com efeito, dos diplomas legais infraconstitucionais que se voltam à temática da discriminação ${ }^{479}$, percebe-se grande variabilidade nos critérios de discrímen enumerados, a depender do enfoque e da finalidade precípua de cada instrumento normativo. Isso significa que os parâmetros discriminatórios expressamente proibidos pelo legislador, dada a sua importância histórica e cultural para o combate aos preconceitos, se encontram dispersos no Direito brasileiro.

Mas, ao se esquadrinhar a legislação federal que integra o Direito da Antidiscriminação, percebe-se que o ordenamento jurídico brasileiro já engloba, sim, a interdição às discriminações que tomam por critério a orientação sexual de um indivíduo ou grupo de indivíduos.

Nesse específico, Rios, Souza e Sponchiado mencionam ao menos quatro diplomas legais que trazem, em seu seio, explícita menção ao critério em questão. $A$ Lei 9.612/1998, por exemplo, consigna que a programação das emissoras do Serviço

\footnotetext{
477 ONU. CCPR/C/50/D/488/1992 (Toonen v. Australia), 1994.

${ }^{478}$ RIOS, Roger Raupp. O direito da antidiscriminação e a tensão entre o direito à diferença e o direito geral de igualdade. Direitos Fundamentais e Justiça, n. 18, p. 169-179, 2012.

${ }^{479}$ A título de exemplo, é possível citar a Lei 7.716/1989, que define os crimes resultantes de discriminação ou preconceito de raça, cor, etnia, religião ou procedência nacional; a Lei 9.029/1995, que cuida das práticas discriminatórias que impedem ou limitam o acesso ao emprego, ou à sua manutenção, por motivo de sexo, origem, raça, cor, estado civil, situação familiar, deficiência, reabilitação profissional, idade; e o art. 239 da Lei 8.112/1990, segundo o qual, "Por motivo de crença religiosa ou de convicção filosófica ou política, o servidor não poderá ser privado de quaisquer dos seus direitos, sofrer discriminação em sua vida funcional".
} 
de Radiodifusão Comunitária deve observar o princípio da não discriminação, no que se refere a "preferências sexuais" (art. 4 , IV). Já a Lei 10.216/2001, em seu art. $1^{\circ}$, elucida que a proteção e os direitos das pessoas portadoras de transtornos mentais são assegurados sem discriminação quanto à orientação sexual. Igualmente, ao firmar instrumentos legais para o enfrentamento da violência doméstica e familiar contra a mulher, a Lei Maria da Penha (Lei 11.340/2006) enuncia, logo em seu introito, que toda mulher, independentemente de orientação sexual, goza dos direitos fundamentais inerentes à pessoa humana; e, mais adiante, em seu art. $5^{\circ}$, parágrafo único, esclarece que as relações domésticas e familiares a que se reporta a legislação independem de orientação sexual. Finalmente, a Lei 12.414/2011 institui proibição a que os bancos de dados sobre adimplemento registrem anotações quanto à orientação sexual dos cadastrados, por se tratar de informação sensível que pode ensejar tratamento discriminatório (art. $\left.3^{\circ}, \S 3^{\circ}, \mathrm{II}\right)^{480}$.

A esses diplomas legais, soma-se a Lei 13.146/2015 (Estatuto da Pessoa com Deficiência), em que se determina que as ações e serviços de saúde voltados às pessoas com deficiência devem assegurar o respeito à orientação sexual desses indivíduos (art. 18, $\left.\S 4^{\circ}, \mathrm{VII}\right)^{481}$.

Vê-se, desse modo, que a proibição às práticas discriminatórias por orientação sexual, implicitamente estabelecida pela Constituição Federal e pelos tratados e convenções de direitos humanos, já foi incorporada expressamente pelo legislador brasileiro ao Direito da Antidiscriminação, como condição de resguardo da dignidade humana, conferindo densidade, na maior amplitude possível, às diretrizes traçadas pelo constitucionalismo inclusivo instaurado desde 1988 no Brasil.

\footnotetext{
${ }^{480}$ RIOS, Roger Raupp; SOUZA, Luiz Gustavo Oliveira de; SPONCHIADO, Tobias. Notícias de homofobia e proteção jurídica antidiscriminatória. In: DINIZ, Debora; OLIVEIRA, Rosana Medeiros de. (Orgs.). Notícias de homofobia no Brasil. Brasília: Letras Livres, 2014, p. 173174.

${ }^{481}$ BRASIL. Lei 13.146/2015 - Lei Brasileira de Inclusão da Pessoa com Deficiência (Estatuto da Pessoa com Deficiência). Diário Oficial da União, 07/07/2015, p. 2.
} 


\section{O DIREITO FUNDAMENTAL AO TRABALHO DIGNO E A DISCRIMINAÇÃO POR ORIENTAÇÃO SEXUAL NAS RELAÇÕES DE EMPREGO}

\subsection{O valor trabalho no Estado Democrático de Direito brasileiro: o direito fundamental ao trabalho digno}

Segundo Delgado, o trabalho, enquanto espécie de atividade humana, constitui suporte de valor, na medida em que a ele, no plano ético, podem ser atribuídas qualidades que the confiram um sentido positivo ou negativo:

(...) tem-se o trabalho como depositário de valor. Se o trabalho for penoso, insalubre ou perigoso, o valor apreendido é negativo; caso o trabalho seja realizado em condições dignas, possibilitando que o trabalhador se reconheça na sua condição humana por meio de sua identidade social, tem-se um valor positivo. Perceba-se: o suporte é o mesmo, o trabalho; o que varia é a sua qualificação ${ }^{482}$.

Reale, em sua teoria tridimensional, já advertia que o Direito, para além de seu âmbito fático e normativo, comporta também uma dimensão valorativa, relacionada à concretização de ideais de justiça. Isso implica dizer que a norma jurídica, ao prescrever determinadas consequências às hipóteses fáticas nela descritas, tem em mira a consecução de objetivos específicos: seja o de alcançar algo valioso ou desejável em um dado contexto histórico; seja o de reprimir a realização do que se reputa pernicioso ou indesejável ${ }^{483}$.

Para o constitucionalismo contemporâneo, a pessoa humana torna-se a fonte primeira dos valores incorporados pelo Direito, de forma que a proteção e a promoção da dignidade, qualidade intrínseca, universal e distintiva da condição humana, se constitui como núcleo da concepção de justiça que subjaz às normas jurídicas ${ }^{484}$.

No Brasil, a promulgação da Constituição Federal de 1988 foi o que promoveu o deslocamento do eixo axiológico do ordenamento jurídico, antes notoriamente patrimonialista, para a pessoa humana e a dignidade que a qualifica.

No âmbito justrabalhista, Delgado e Borges frisam que a disciplina celetista dá década de 1940 limitava o escopo de aplicação do princípio da proteção ${ }^{485}$, de

\footnotetext{
${ }^{482}$ DELGADO, Gabriela Neves. O trabalho enquanto suporte de valor. Revista da Faculdade de Direito da UFMG. Belo Horizonte, n. 49, p. 63-80, jul./dez. 2006, p. 71.

${ }^{483}$ Sobre a concepção tridimensional do Direito exposta por Reale, cf. REALE, Miguel. Lições preliminares de direito. 27. ed. São Paulo: Saraiva, 2002; e Id., Teoria Tridimensional do Direito. 5. ed. São Paulo: Saraiva, 2002.

${ }^{484}$ REALE, Miguel. Lições preliminares de direito. 27. ed. São Paulo: Saraiva, 2002.

${ }^{485} \mathrm{O}$ Direito do Trabalho se distingue dos demais ramos do Direito pela ênfase que confere, desde sua origem, à função teológica que lhe é subjacente, moldando toda a sua estrutura
} 
início, à modalidade de trabalho urbano, bem como à resolução de questões de matiz contratual e aos direitos patrimoniais do trabalhador. E, mesmo com a paulatina expansão do âmbito de tutela justrabalhista, ao longo das décadas pré-1988, incluindo sob o seu manto formas de prestação do trabalho até então deixadas à margem do regime jurídico especializado (como é o caso do trabalho rural, no fim da década de 1960), não se observou mudança na inclinação patrimonialista das questões objeto da regulação jurídica ${ }^{486}$.

Essa concepção restritiva e fechada do princípio protetivo só viria a ser submetida a uma releitura, a partir das novas lentes inclusivas aportadas ao Direito do Trabalho pela promulgação da Constituição Federal de 1988, em termos de democracia participativa e da centralidade da figura da pessoa humana, amparada e promovida pela realização de direitos fundamentais ${ }^{487}$.

A adoção da nova matriz principiológica pelo Direito brasileiro, em 1988, impõe, por conseguinte, uma revisitação de todo o direito pré-constitucional, de modo que, excluído no que for incompatível com a nova ordem, seja o restante reinterpretado às luzes dos parâmetros que orientam a novel Constituição.

Nesse contexto, em se tratando o trabalho de um direito humano de segunda dimensão e, concomitantemente, de um direito fundamental incorporado pelos textos constitucionais que, a exemplo da Constituição Federal de 1988, se alinham ao paradigma do Estado Democrático de Direito, a definição de seu sentido axiológico passa a se vincular necessariamente à realização da dignidade.

com vistas a promover a "melhoria das condições de pactuação da força de trabalho na ordem socioeconômica" (DELGADO, Maurício Godinho. Curso de direito do trabalho. 11. ed. São Paulo: LTr, 2012, 58). Essa inclinação particular que atravessa a história do Direito do Trabalho é o que o caracteriza como importante ferramenta de justiça social, pela qual o Estado intervém em relações privadas marcadamente desiguais, por meio da adjudicação de direitos ao sujeito trabalhador, em nível individual e coletivo (sobre o tema, consultar: SOUTO MAIOR, Jorge Luiz. A fúria. Revista do Tribunal Superior do Trabalho, Brasília, v. 68, n. 3, jul./dez. de 2002). De acordo com a doutrina, essa finalidade precípua do ramo justrabalhista expressa-se, principalmente, através do princípio da proteção (também conhecido como tutelar ou tuitivo). Dessa diretriz central decorre o imperativo para que o ordenamento justrabalista engendre, "em seu interior, com suas regras, institutos, princípios e presunções próprias, uma teia de proteção à parte hipossuficiente na relação empregatícia — o obreiro , visando retificar (ou atenuar), no plano jurídico, o desequilíbrio inerente ao plano fático do contrato de trabalho" (DELGADO, op. cit., p. 193).

${ }^{486}$ DELGADO, Gabriela Neves; BORGES, Lara Parreira de Faria. A revisitação do princípio da proteção pelo discurso constitucional trabalhista no Tribunal Superior do Trabalho. In: DELGADO, Gabriela Neves; et. al (coord.). Direito constitucional do trabalho: princípios e jurisdição constitucional do TST. São Paulo: LTr, 2015, p. 38.

${ }^{487}$ Ibid., p. 44. 
É dizer, o valor da pessoa humana serve de chave para o discurso constitucional trabalhista, seletivamente, delimitar a ideia positiva de trabalho que a Constituição tutela e estimula, ao mesmo tempo em que baliza as concepções negativas de trabalho constitucionalmente rechaçadas e combatidas.

Em relação ao Direito do Trabalho, a mudança de paradigma operada pela Constituição Federal de 1988 importou uma ressignificação de seus institutos e normas, em especial do princípio tuitivo, cujo escopo foi significativamente ampliado em comparação com sua origem celetista.

O direito fundamental ao trabalho ao qual alude a Constituição da República em seu art. $6^{\circ}$, assegurado principalmente por meio dos institutos, valores, princípios e regras que compõem o Direito do Trabalho, diz respeito, portanto, às configurações de trabalho que dignificam a pessoa humana; jamais ao labor que instrumentaliza o obreiro e desconsidera a pessoa como um fim em si mesmo, que busca no trabalho as condições para se realizar e participar de forma paritária da vida social ${ }^{488}$.

Essa premissa se torna evidente, na Constituição de 1988, quando são elencados lado a lado, como princípios fundamentais da república, a dignidade da pessoa humana e o valor social do trabalho (art. $1^{\circ}$, III e IV), fontes das quais decorrem os direitos fundamentais trabalhistas arrolados em seu art. $7^{\circ}$. A ideia é reafirmada pelo constituinte, ao asseverar que a ordem econômica e a ordem social, fundadas no primado e na valorização do trabalho humano, têm por objetivo a assegurar a existência digna e realizar a justiça social (artigos 170 e 193). Essa finalidade, vale frisar, só se cumpre quando a atividade econômica se orienta pelo princípio da defesa do meio ambiente equilibrado - inclusive o meio ambiente do trabalho (artigos 170, VI, e 200, VIII).

Nesse quadro, a função teleológica do Direito, em relação ao trabalho, é a de garantir o acesso e o seu exercício em condições de dignidade, suprimindo modalidades que aviltem a condição humana. Isso se perfaz pela estruturação de uma rede protetiva de direitos de indisponibilidade absoluta, que não se sujeitam à transação, nem individual nem coletiva ${ }^{489}$, por:

(...) se constituírem em um patamar civilizatório mínimo que a sociedade democrática não concebe ver reduzido em qualquer segmento econômico-profissional, sob pena de se afrontarem a

\footnotetext{
${ }^{488}$ DELGADO, Gabriela Neves. Direito fundamental ao trabalho digno. 2. ed. São Paulo: LTr, 2015, p. 27.

${ }^{489}$ Ibid., p. 182.
} 
própria dignidade da pessoa humana e a valorização mínima deferível ao trabalho ${ }^{490}$.

Esse conjunto inegociável de direitos que ampara o patamar mínimo civilizatório do sujeito trabalhador, como derivação e concretização do valor dignidade, são direitos humanos e, no que constitucionalmente positivados, também direitos fundamentais ${ }^{491}$.

Nessa esteira, proteger e fomentar a dignidade do sujeito trabalhador na maior amplitude possível, em atenção ao paradigma inclusivo e aberto de direitos fundamentais inaugurado pela Constituição Federal de 1988, exige do discurso constitucional trabalhista a revisitação do modelo protetivo arquitetado pela CLT quarenta anos antes, conferindo-lhe um enfoque multidimensional em contínuo aperfeiçoamento, com pretensão de fazer frente à hipercomplexidade da vida nas sociedades contemporâneas $^{492}$.

Não basta mais, para o padrão tuitivo inaugurado pelo Texto Constitucional de 1988, uma tutela circunscrita a interesses patrimoniais oriundos da relação contratual empregatícia bilateral. Para que se possa falar em efetivo trabalho digno, de viés inclusivo, o Direito do Trabalho hodierno precisa atentar para outras formas de trabalho ainda não alcançadas pelo ordenamento justrabalhista. Igualmente, deve voltar-se para os indivíduos que, por sua condição socioeconômica ou por estigmas sociais, encontram maiores dificuldades para verem concretizado o direito ao acesso e à manutenção no emprego em condições dignas. $E$, no mesmo passo, não pode descuidar dos interesses extrapatrimoniais de natureza individual, coletiva e difusa dos trabalhadores. Nesse sentido, o princípio protetivo, à vista do constitucionalismo brasileiro de 1988, deve levar em conta simultaneamente "o sujeito trabalhador, o objeto do trabalho e o meio ambiente de trabalho", na realização de sua função teleológica $^{493}$.

Uma estrutura similar de valoração do trabalho, pode ser encontrada também no plano internacional.

490 DELGADO, Maurício Godinho. Curso de direito do trabalho. 13. ed. São Paulo: LTr, 2011 , p. 881.

491 DELGADO, Gabriela Neves. Direito fundamental ao trabalho digno. 2. ed. São Paulo: LTr, 2015, p. 184-185.

492 DELGADO, Gabriela Neves; BORGES, Lara Parreira de Faria. A revisitação do princípio da proteção pelo discurso constitucional trabalhista no Tribunal Superior do Trabalho. In: DELGADO, Gabriela Neves; et. al (coord.). Direito constitucional do trabalho: princípios e jurisdição constitucional do TST. São Paulo: LTr, 2015, p. 40.

${ }^{493}$ Ibid., p. 44. 
Com efeito, se a ideia de direitos humanos denota um conjunto mínimo de direitos que, por consenso, são universais e devem ser garantidos a toda e qualquer pessoa como condição para uma vida digna, é nesse elenco de direitos que se deve buscar o verdadeiro sentido de trabalho decente, isto é, trabalho exercido em condições de dignidade ${ }^{494}$.

O homem enquanto trabalhador é, pois, sujeito de direitos humanos de segunda dimensão, de conotação social, positiva, expressamente abordados pela Declaração Universal dos Direitos Humanos de 1948, simbolicamente o mais importante diploma já editado sobre a temática dos direitos humanos ${ }^{495}$. Também firmado no âmbito da Organização das Nações Unidas, o Pacto Internacional sobre Direitos Econômicos, Sociais e Culturais, ratificado pelo Brasil em 1992, enuncia o direito de toda pessoa a ganhar a vida mediante um trabalho livremente escolhido ou aceito, prestado em condições justas e favoráveis ${ }^{496}$.

Sem embargo, para Brito Filho, o corpo mais completo de garantias mínimas de que se pode dessumir o efetivo conteúdo do trabalho decente há de ser buscado no rol de Convenções Fundamentais firmadas pela Organização Internacional do Trabalho, quais sejam: as de número $87^{497}$ e 98 , sobre liberdade sindical e de associação, bem como reconhecimento das negociações coletivas; 27 e 105, sobre a proibição ao trabalho forçado; 138 e 182, sobre proibição ao trabalho infantil; e 100 e 111 , sobre proibição da discriminação ${ }^{498}$.

Os direitos e garantias enunciados por esses diplomas encontram-se elencados na Declaração da OIT sobre os Princípios e Direitos Fundamentais no

${ }^{494}$ BRITO FILHO, José Cláudio Monteiro de Brito Filho. Trabalho decente: análise jurídica da exploração do trabalho - trabalho escravo e outras formas de trabalho indigno. 3. ed. São Paulo: LTr, 2013, p. 25.

495 ONU. Declaração Universal dos Direitos Humanos, 1948. Disponível em:<http://www.ohchr.org/EN/UDHR/Documents/UDHR_Translations/por.pdf>. Acesso em 2 de abril de 2016.

${ }^{496}$ BRASIL. Decreto n. 591. Promulga o Pacto Internacional Sobre os Direitos Econômicos, Sociais e Culturais. Diário Oficial da União, 07/07/1992, p. 8713.

${ }^{497}$ Adotada em 1948 pela OIT, a Convenção 87 não foi ratificada pelo Estado brasileiro, tendo em vista a imposição constitucional da unicidade sindical, uma restrição ao princípio da liberdade sindical de teor corporativista e autoritário que se manteve na Constituição Federal de 1988, a despeito de seu caráter geral democrático, plural e inclusivo. DELGADO, Maurício Godinho. Curso de direito do trabalho. 11. ed. São Paulo: LTr, 2012, p. 1334.

${ }^{498}$ BRITO FILHO, op. cit., p. 46. 
Trabalho e seu seguimento, adotada em $1998^{499}$, e constituem o parâmetro basilar para o trabalho digno, de observância obrigatória pelos membros da Organização:

2. Declara que todos os Membros, ainda que não tenham ratificado as Convenções, têm um compromisso derivado do simples fato de pertencer à Organização de respeitar, promover e tornar realidade, de boa fé e de conformidade com a Constituição, os princípios relativos aos direitos fundamentais que são objeto dessas Convenções, isto é:

(a) a liberdade sindical e o reconhecimento efetivo do direito de negociação coletiva;

(b) a eliminação de todas as formas de trabalho forçado ou obrigatório;

(c) a efetiva abolição do trabalho infantil; e

(d) a eliminação da discriminação em matéria de emprego e ocupação ${ }^{500}$.

Diante desse quadro, tomado o conjunto do ordenamento justrabalhista brasileiro, essa rede protetiva complexa de direitos indisponíveis se encontra distribuída em três grandes eixos jurídicos. O primeiro eixo comporta a proteção jurídica proveniente dos tratados e convenções internacionais ratificadas pelo país (principalmente tratados sobre direitos humanos e convenções fundamentais da Organização Internacional do Trabalho), que elencam direitos universalmente reconhecidos como garantias mínimas de resguardo à dignidade do ser humano trabalhador. O segundo eixo, por sua vez, figura no Texto Constitucional, sobretudo em seu art. $7^{\circ}$, e denota a institucionalização, no plano do ordenamento jurídico pátrio, dos direitos humanos do trabalhador como direitos fundamentais. Já o terceiro eixo comporta aqueles direitos que figuram na legislação infraconstitucional, mas que, por veicularem matéria de interesse público diretamente derivada da dignidade, como a tutela da saúde do trabalhador ou de sua integridade psíquica e física, tornam-se igualmente indisponíveis ${ }^{501}$.

Não por acaso, normas voltadas à promoção da igualdade substancial, ao respeito à diferença e, por conseguinte, ao combate às discriminações no mundo do

499 Sobre o tema, consultar GOMES, Ana Virgínia Moreira; FREITAS JÚNIOR, Antônio Rodrigues de. (Org.). A Declaração de 1998 da OIT sobre princípios e direitos fundamentais no trabalho: análise do seu significado e efeitos. São Paulo: LTr, 2014; e NICOLI, Pedro Augusto Gravatá. A condição jurídica do trabalhador imigrante no direito brasileiro. São Paulo: LTr, 2011.

500 OIT. Declaração da OIT sobre os princípios e direitos fundamentais no trabalho e seu seguimento. Disponível em:<http://www.ilo.org/wcmsp5/groups/public/---americas/---rolima/---ilo-brasilia/documents/publication/wcms_230648.pdf>. Acesso em 4 de abril de 2016.

501 DELGADO, Gabriela Neves. Direito fundamental ao trabalho digno. 2. ed. São Paulo: LTr, 2015, p. 188-189. 
trabalho, mormente na dinâmica das relações de emprego, são elementos comuns aos três eixos jurídicos de proteção ao trabalho digno.

Logo, práticas discriminatórias em matéria de emprego, como as motivadas por orientação sexual, por suas consequências individuais e coletivas, são incompativeis (e, bem assim, antitéticas) com o padrão de trabalho constitucionalmente resguardado que dignifica o homem trabalhador. O discurso constitucional trabalhista, por conseguinte, nega a assimilação, à identidade do sujeito constitucional, do trabalho prestado sob condições discriminatórias.

\subsection{A proibição da discriminação por orientação sexual como exigência do direito fundamental ao trabalho digno}

Se a evolução moral da humanidade se traduz, em grande medida, em uma luta por reconhecimento, a fim de que, tendo em vista a igual dignidade de todos, diferenças entre as pessoas não sejam usadas como subsídio para criar e perpetuar injustiças, esse processo evolutivo há de se realizar, portanto, por meio da paulatina eliminação de todas as formas de discriminação, inclusive e necessariamente aquela perpetrada no mundo do trabalho 502 .

De fato, observa Nicoli, "a diretriz da Constituição de 1988 no sentido de vedar práticas discriminatórias é resultado de um processo de amadurecimento da proteção à pessoa humana"503.

Isto posto, todo e qualquer sistema de direitos destinado à proteção do homem trabalhador e comprometido com a perspectiva do trabalho em condições de dignidade, como a única configuração capaz de reduzir o sofrimento humano e converter-se em espaço de integração social e autorrealização, deve abordar em algum grau o tema da discriminação.

Na esfera dos direitos humanos, em sua conformação contemporânea, esse compromisso justrabalhista é facilmente perceptível. A promoção da igualdade no mundo do trabalho figura, afinal, entre os objetivos fundamentais que orientam as atividades e pautas da Organização Internacional do Trabalho ${ }^{504}$.

\footnotetext{
${ }^{502}$ MALLET, Estevão. Igualdade, discriminação e direito do trabalho. Rev. TST, v. 76, n. 3, p. 17-51, jul./set. 2010, p. 18.

${ }^{503}$ NICOLI, Pedro Augusto Gravatá. A condição jurídica do trabalhador imigrante no direito brasileiro. São Paulo: LTr, 2011, p. 104.

${ }^{504}$ MALLET, op. cit., p. 19.
} 
Consoante enuncia a Declaração de Filadélfia de 1944, parte integrante da Constituição da OIT aprovada na $26^{a}$ reunião da Conferência Internacional do Trabalho, "todos os seres humanos de qualquer raça, crença ou sexo, têm o direito de assegurar o bem estar material e o desenvolvimento espiritual dentro da liberdade e da dignidade, da tranquilidade econômica e com as mesmas possibilidades" ${ }^{505}$.

O engajamento da OIT no combate à discriminação, por conseguinte, está inscrito na trajetória histórica da Organização, como uma "necessidade permanente quando da pretensão de atingir um trabalho digno, em condições de liberdade, igualdade de oportunidades, proteção, e garantia à dignidade humana da pessoa do trabalhador" ${ }^{\prime 206}$.

Esse é o fundamento que subjaz à Convenção de $\mathrm{n}^{0} 100$, voltada a fomentar a igualdade de remuneração entre homens e mulheres por trabalho de igual valor. Igualmente, é um dos pilares dos demais diplomas da Organização, que analisam o enfrentamento às práticas discriminatórias, mesmo que lateralmente, como as Convenções 117 (Objetivos e Normas Básicas da Política Social), 122 (Política de Emprego) e 156 (Trabalhadores com Encargos de Família - não ratificada pelo Brasil).

No entanto, é pela a Convenção 111 da OIT, aprovada em 1958 e ratificada pelo Brasil em 1965, que se instituiu um dever geral aos Estados signatários de enfrentamento a toda espécie de discriminação que possa se manifestar na dinâmica das relações de trabalho. Nos termos da convenção, a discriminação no trabalho é definida como:

Toda distinção, exclusão ou preferência fundada na raça, cor, sexo, religião, opinião política, ascendência nacional ou origem social, que tenha por efeito destruir ou alterar a igualdade de oportunidades ou de tratamento em matéria de emprego ou profissão ${ }^{507}$.

Diante deste conceito, os subscritores da Convenção comprometem-se, consoante disposto em seu art. $2^{\circ}$, a elaborar e aplicar políticas de promoção da

\footnotetext{
505 BRASIL. Congresso Nacional. Decreto n. 25.696. Diário Oficial da União, Seção 1, 24/11/1948, Página 16773.

${ }^{506}$ COUTINHO, Maria Luiza Pinheiro. Discriminação no Trabalho: Mecanismos de Combate à Discriminação e Promoção de Igualdade de Oportunidades. Disponível em: <http://www.oitbrasil.org.br/sites/default/files/topic/discrimination/pub/oit_igualdade_racial_05 234.pdf>. Acesso em 29 de março de 2016.

${ }^{507}$ BRASIL. Decreto 65.150 (promulga a Convenção $n^{\circ} 111$ da OIT). DOFC DE 23/01/1968, p. 745.
} 
igualdade em matéria de emprego, de modo a eliminar todas as formas de discriminação que lhe sejam relacionadas.

Esse compromisso foi renovado pela OIT, ao se adotar, em 1998, a Declaração sobre os Princípios e Direitos Fundamentais no Trabalho, elencando como uma das garantias mínimas para o trabalho digno a eliminação da discriminação em matéria de emprego e ocupação.

Em que pese a discriminação empregatícia fundada em orientação sexual careça de menção expressa nas convenções da Organização, a Recomendação 200 sobre o HIV e a AIDS no mundo do trabalho, adotada na 99ª Sessão da Conferência Geral da OIT, em 2010, partindo da orientação sedimentada pela Convenção 111, conclama os Estados membros a adotarem medidas que favoreçam o "envolvimento e o empoderamento de todos os trabalhadores, independentemente da sua orientação sexual ou porque façam ou não parte de grupos vulneráveis"

Ainda nessa esteira, dando seguimento à Declaração sobre os Princípios e Direitos Fundamentais no Trabalho, os relatórios globais sobre igualdade no trabalho dos anos de 2007 e 2011 têm capítulos inteiramente dedicados à exposição dos efeitos da discriminação homofóbica no mundo do trabalho, dos avanços conquistados e da necessidades ainda não atendidas ${ }^{509}$.

Mais recentemente, em 2014, em um esforço conjunto da Organização com o Programa Conjunto das Nações Unidas sobre HIVIAIDS (UNAIDS) e o Programa das Nações Unidas para o Desenvolvimento (PNUD), foi editada a obra "Promoção dos Direitos Humanos de pessoas LGBT no Mundo do Trabalho", inteiramente dedicada à identificação das principais formas de discriminação enfrentadas pela população LGBT nesse contexto, bem como das estratégias, ações e ferramentas para superálas, com vistas à promoção do trabalho decente, enquanto direito de todos, independentemente de orientação sexual ou identidade e expressão de gênero. $A$ publicação já está em sua segunda edição, lançada em novembro de $2015^{510}$.

\footnotetext{
${ }^{508}$ OIT. R200 - Recomendação sobre o HIV e a AIDS e o Mundo do Trabalho, 2010.

${ }^{509}$ Cf. Id., Igualdade no trabalho: um desafio contínuo. Relatório Global no quadro do seguimento da Declaração sobre os Princípios e Direitos Fundamentais no Trabalho. Genebra: OIT, 2011; Id., Igualdade no trabalho: enfrentando desafios. Relatório Global no quadro do seguimento da Declaração sobre os Princípios e Direitos Fundamentais no Trabalho. Genebra: OIT, 2007.

${ }^{510}$ OIT; UNAIDS; PNUD. Promoção dos Direitos Humanos de pessoas LGBT no Mundo do Trabalho. 2. ed. revista e ampliada. OIT, 2015.
} 
Fora do âmbito da OIT, outros instrumentos internacionais de direitos humanos também instituem, para o Brasil, enquanto Estado signatário, a obrigação de adotar políticas para a promoção da igualdade no mundo do trabalho, o que perpassa o combate a todo e qualquer tratamento discriminatório aviltante.

A Declaração Universal dos Direitos Humanos de 1948, nesse específico, dispõe:

Artigo 23.

1. Todo ser humano tem direito ao trabalho, à livre escolha de emprego, a condições justas e favoráveis de trabalho e à proteção contra o desemprego.

2. Todo ser humano, sem qualquer distinção, tem direito a igual remuneração por igual trabalho.

3. Todo ser humano que trabalhe tem direito a uma remuneração justa e satisfatória, que lhe assegure, assim como à sua família, uma existência compatível com a dignidade humana, e a que se acrescentarão, se necessário, outros meios de proteção social ${ }^{511}$.

No mesmo rumo, o Pacto Internacional Sobre os Direitos Econômicos, Sociais e Culturais, ratificado em 1992, traz também uma série de direitos sociais de natureza trabalhista, cujo exercício deve ser assegurado pelos Estados subscritores, "sem discriminação alguma por motivo de raça, cor, sexo, língua, religião, opinião política ou de outra natureza, origem nacional ou social, situação econômica, nascimento ou qualquer outra situação" ${ }^{512}$.

Nesse específico, é oportuno mencionar a interpretação do Comitê sobre os Direitos Econômicos, Sociais e Culturais quanto ao direito ao trabalho, enunciado em seu art. $6^{\circ}$, em sua dimensão de acesso ao trabalho, cuja garantia dependeria do repúdio à discriminação por orientação sexual:

Sob seu artigo $2^{\circ}$, parágrafo $2^{\circ}$, e no artigo $3^{\circ}$, o Pacto proíbe qualquer discriminação no acesso ao e manutenção de emprego por motivos de raça, cor , sexo, língua, religião, opinião política ou outra, nacional ou origem social , riqueza, nascimento , deficiência física ou mental, estado de saúde (Incluindo HIV / AIDS), orientação sexual (... $)^{513}$.

No plano constitucional, por sua vez, a promulgação da Constituição Federal de 1988 representa um marco divisor no tratamento jurídico conferido à discriminação

\footnotetext{
511 ONU. Declaração Universal dos Direitos Humanos, 1948. Disponível em:<http://www.ohchr.org/EN/UDHR/Documents/UDHR_Translations/por.pdf>. Acesso em 2 de abril de 2016.

512 BRASIL. Decreto n. 591. Promulga o Pacto Internacional Sobre os Direitos Econômicos, Sociais e Culturais. Diário Oficial da União, 07/07/1992, p. 8713.

${ }^{513}$ ONU (Comitê sobre Direitos Econômicos, Sociais e Culturais - Conselho Econômico e Social. E/C.12/GC/18 (O direito ao trabalho - Comentário Geral n 18), 2006.
} 
empregatícia no Brasil. Em contraste com o período anterior, caracterizado por referências normativas esparsas sobre o tema, a nova Constituição, observa Godinho Delgado, firma as bases para o surgimento de um "largo e consistente sistema de proteções jurídicas contra discriminações empregatícias", avançando, com sua perspectiva humanista e inclusiva, também sobre as repercussões de natureza extrapatrimonial do tratamento discriminatório ${ }^{514}$.

O bloco tradicional de normas contra a discriminação aplicáveis às relações de emprego era composto, basicamente, por dispositivos desconexos, em sua maioria circunscritos às consequências remuneratórias da discriminação, espalhados pela CLT, pelas Constituições anteriores a 1988 e, eventualmente, por diplomas legais estranhos ao Direito do Trabalho. Essa perspectiva patrimonialista fica evidente no art. $5^{\circ}$ da CLT, segundo o qual "A todo trabalho de igual valor corresponderá salário igual, sem distinção de sexo". Ampliando o leque de critérios que não se prestariam a justificar o pagamento de remunerações diferenciadas, o art.157, II, da Constituição Federal de 1946 acrescia idade, nacionalidade e estado civil. As Cartas de 1967 e 1969, fariam modificações pontuais nesses parâmetros, que passariam a ser observados também quando da admissão de empregados ${ }^{515}$.

Já a Constituição de 1988, ao enunciar o próprio princípio da igualdade, no art. $5^{\circ}$, traz vedação às distinções discriminatórias como consectário lógico de sua garantia: "todos são iguais perante a lei, sem distinção de qualquer natureza". Disto decorre a determinação de que "a lei punirá qualquer discriminação atentatória dos direitos e liberdades fundamentais" (inciso XLI), instituindo o constituinte verdadeira obrigação para o legislador ordinário, com vistas à implementação de mecanismos voltados ao combate a todas as formas de discriminação.

Essa assertiva, aliás, se coaduna com o objetivo fundamental da República brasileira de "promover o bem de todos, sem preconceitos de origem, raça, sexo, cor, idade e quaisquer outras formas de discriminação" (art. $3^{\circ}$, IV). A diretriz antidiscriminatória revela-se, assim, aberta à contínua revisitação e aperfeiçoamento, pois, ao invés de enumerar taxativamente os critérios de diferenciação interditados, como já se frisou, ela apenas os exemplifica, deixando espaço para que o discurso

${ }^{514}$ DELGADO, Maurício Godinho. Proteções contra discriminação na relação de emprego. In: RENAULT, Luiz Otávio Linhares; VIANA, Márcio Túlio; CANTELLI, Paula Oliveira (coord.). Discriminação. 2. ed. São Paulo: LTr, 2010, p.109.

${ }^{515}$ Ibid., p. 110. 
constitucional densifique esse enunciado, incluindo em seu âmbito de incidência outras motivações discriminatórias que atentem contra a dignidade humana, como às de que são alvos as pessoas homossexuais.

O parâmetro geral de combate à discriminação reflete-se, na mesma medida, num conjunto articulado, com vocação igualmente expansionista, de normas constitucionais voltadas ao mundo do trabalho, em especial para as relações de emprego.

O constituinte, assentando a igualdade entre homens e mulheres (art. $5^{\circ}, \mathrm{I}$ ), determinou a estruturação de um sistema de "proteção do mercado de trabalho da mulher, mediante incentivos específicos" (art. $7^{\circ}, \mathrm{XX}$ ) e conferiu garantias às gestantes, como o direito à estabilidade provisória no emprego e à licença maternidade (nesse sentido, os artigos $7^{\circ}$, XVIII, e 201, II, da Constituição e 10, II, b, do ADCT). No mesmo passo, à vista dos princípios da proteção integral e da prioridade absoluta $^{516}$ (art. 227), o texto constitucional, além de vedar a diferenciação salarial e

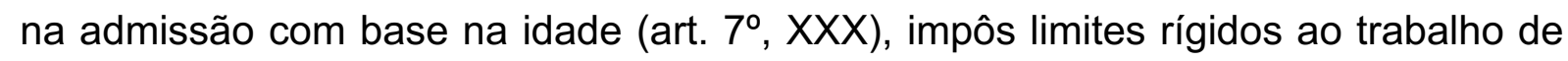

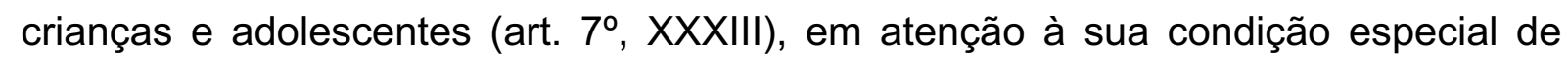
pessoa em desenvolvimento, garantindo-lhes, de todo modo a totalidade dos direitos trabalhistas e previdenciários, bem como o acesso à educação (art. 227, § $3^{\circ}$, I e II). Vedou-se, ainda, a discriminação quanto ao tipo de trabalho, desautorizando distinções entre o trabalho manual, técnico ou intelectual, e entre os profissionais que os desempenham $\left(7^{\circ}, \mathrm{XXXII)}\right.$. A proibição da discriminação quanto a salários e critérios de admissão, vale notar, também se estende, de modo não taxativo, aos parâmetros de cor, sexo e estado civil $\left(7^{\circ}, \mathrm{XXX}\right)$, bem como aos portadores de necessidades especiais (art. $7^{\circ}, \mathrm{XXXI}$ ) — proteção essa reforçada pela promulgação, com força de emenda constitucional, da Convenção Internacional sobre os Direitos das Pessoas com Deficiência e seu Protocolo Facultativo.

Particularmente no que concerne ao trabalhador homossexual, já se viu que a instrumentalização do indivíduo, por meio de práticas discriminatórias embasadas em sua orientação sexual, sejam elas perpetradas pelo empregador, por superiores hierárquicos ou por outros obreiros, tem o condão de desacreditá-lo perante o grupo

${ }^{516}$ A respeito da Doutrina da Proteção Integral, consultar: PEREIRA, Tânia da Silva. Direito da Criança e do Adolescente: uma proposta interdisciplinar. 1. ed. Rio de Janeiro: Renovar / UNICEF, 1996; e Id., O melhor interesse da criança: um debate interdisciplinar. Rio de Janeiro: Renovar, 2000. 
social, ferindo a imagem e o respeito que as outras pessoas têm para com ele, bem como de atentar contra a estima que o trabalhador mantém em relação a si mesmo, gerando constrangimento e vergonha ${ }^{517}$.

Nesse rumo, a discriminação por orientação sexual tem aptidão para violar não apenas a honra objetiva e subjetiva ${ }^{518}$, como também a intimidade e a vida privada do trabalhador, direitos da personalidade constitucionalmente protegidos (art. $5^{\circ}$, $\mathrm{X})^{519}$.

Disto se extrai uma das mais evidentes consequências jurídicas das condutas discriminatórias, comissivas ou omissivas, na dinâmica das relações de emprego: $O$ dever de indenizar o trabalhador discriminado ${ }^{520}$.

A responsabilidade civil implica um dever jurídico de reparação, de caráter sucessivo ou secundário (art. 927 do Código Civil), porquanto decorrente da inobservância, pelo sujeito, de um dever jurídico primário (artigos 186 e 187 do Código Civil $^{521}$ : o de não praticar ato ilícito consistente tanto na violação dos direitos de outrem, ainda que exclusivamente morais, quanto no exercício abusivo de direito próprio.

Viu-se que há proibição jurídica (em nível legal, supralegal e constitucional) a condutas discriminatórias, incluídas as motivadas por ou direcionadas à orientação sexual, que tenham o propósito ou o efeito de impedir o reconhecimento, o exercício ou o gozo de direitos em condições de igualdade com as demais pessoas. 0 cumprimento desse dever, vale lembrar, é decorrência direta dos direitos fundamentais à igualdade, à intimidade, à honra, à vida privada e à imagem (art. $5^{\circ}$, V e X, da Constituição) - em última instância, da própria proteção jurídica à dignidade humana.

\footnotetext{
${ }^{517}$ A esse respeito, consultar item 2.3 do Capítulo 2.

${ }^{518}$ Belmonte assevera que a honra "Reúne o caráter subjetivo, traduzido no conceito que o indivíduo faz de si próprio ou dignidade por ele experimentada, como o aspecto objetivo, assim considerada a reputação e fama desfrutadas no meio social". BELMONTE, Alexandre Agra. Responsabilidade por danos morais no Direito do Trabalho. Revista do Tribunal Superior do Trabalho, v. 73, n. 2, p. 25-45, abr./jun. 2007, p. 169.

${ }^{519}$ BARROS, Alice Monteiro de. Curso de direito do trabalho. 7. ed. São Paulo: LTr, 2011, p. 956.

${ }_{520}$ A Emenda Constitucional 45/2004, acrescendo o inciso VI ao art. 114 da Constituição, inseriu expressamente, no âmbito da jurisdição trabalhista, a competência para processar e julgar processos em que se discutam danos materiais ou morais oriundos da relação de trabalho.

${ }^{521}$ GONÇALVES, Carlos Roberto. Direito civil brasileiro, vol. 4: responsabilidade civil. 5. ed. São Paulo: Saraiva: 2010, p. 24.
} 
Neste passo, aquele que incorre em conduta discriminatória contra homossexuais, inclusive nas diversas fases da relação empregatícia (pré-contratual, contratual e pós-contratual), causando danos de ordem patrimonial ou extrapatrimonial, comete ato ilícito e se obriga, assim, a repará-los.

O empregador, aliás, por expressa disposição nesse sentido (artigos 932, II, e 933 do Código Civil), responde, independentemente de culpa, pelos danos causados a terceiros por atos discriminatórios de seus empregados ou prepostos cometidos no exercício de suas funções. Os pressupostos para que essa responsabilização ocorra, segundo Gonçalves, são:

$\left.1^{\circ}\right)$ qualidade de empregado, serviçal ou preposto, do causador do dano (prova de que o dano foi causado por preposto);

$2^{\circ}$ ) conduta culposa (dolo ou culpa stricto sensu) do preposto;

$3^{\circ}$ ) que o ato lesivo tenha sido praticado no exercício da função que Ihe competia, ou em razão dela ${ }^{522}$.

É pertinente sublinhar ainda que, no que toca à compensação por dano moral ou extrapatrimonial, dispensa-se prova concreta do prejuízo à esfera anímica do sujeito lesado. A ocorrência do dano, nesses casos, é presumida, bastando ao sujeito discriminado comprovar o evento danoso, isto é, o cometimento do ato discriminatório ilícito pelo agente e o respectivo nexo de causalidade ${ }^{523}$.

A reparação ou a compensação de danos ao patrimônio material e imaterial do trabalhador, em virtude de condutas discriminatórias, não se limita, porém, ao plano individual.

Como tende a ocorrer com o assédio moral não debelado em seus estágios iniciais, se a discriminação perpetrada atingir interesses difusos ou coletivos, afetando, por exemplo, o meio ambiente de trabalho, é cabível ação civil pública (Lei 7.347/1985) para suscitar a responsabilidade civil do empregador pelos danos morais causados a essa coletividade ${ }^{524}$.

A par da reparação civil, constitucional e legalmente assegurada, a legislação trabalhista infraconstitucional prescreve uma série de consequências jurídicas específicas para o cometimento de atos discriminatórios no âmbito das relações empregatícias.

${ }^{522}$ GONÇALVES, Carlos Roberto. Direito civil brasileiro, vol. 4: responsabilidade civil. 5. ed. São Paulo: Saraiva: 2010, p. 127.

${ }^{523}$ Ibid., p. 389-390.

524 PEDUZZI, Maria Cristina Irigoyen. Assédio moral. Revista do Tribunal Superior do Trabalho, v. 73, n. 2, p. 25-45, abr./jun. 2007, p. 39. 
Cumpre ver, de início, que a CLT considera o ato lesivo da honra e da boa fama do empregado, praticado pelo empregador ou por seus prepostos, uma das hipóteses que autoriza a rescisão indireta do contrato de trabalho (art. 483) ${ }^{525}$. 0 mesmo se faz possível quando, embora não explicitada a ofensa homofóbica, a discriminação sorrateiramente se traduza em assédio moral praticado contra o indivíduo, em função de sua orientação sexual, fragilizando sua integridade psíquica por meio de condutas como a exigência ou a redução desproporcional de serviços, demandando o trabalhador além de suas capacidades ou relegando-o à ociosidade; assim como o excesso de rigor do empregador ou dos superiores hierárquicos no trato com obreiro (art. 483, a, b e g) ${ }^{526}$.

Outrossim, a partir da promulgação da Lei 9.799/1999, a CLT passou a explicitar que a vedação justrabalhista à discriminação incide desde a fase précontratual, quando da divulgação de anúncios de emprego que imponham restrições de viés discriminatório. Nesse passo, dispõe o art. 373-A, I, da CLT:

Art. 373-A. Ressalvadas as disposições legais destinadas a corrigir as distorções que afetam o acesso da mulher ao mercado de trabalho e certas especificidades estabelecidas nos acordos trabalhistas, é vedado:

I - publicar ou fazer publicar anúncio de emprego no qual haja referência ao sexo, à idade, à cor ou situação familiar, salvo quando a natureza da atividade a ser exercida, pública e notoriamente, assim o exigir $^{527}$;

Note-se que, de acordo com o dispositivo, incide em conduta vedada pelo ordenamento justrabalhista tanto a empresa tomadora de serviços que contrata terceiro para fazer a publicidade ilícita quanto a empresa contratada pela empregadora que efetivamente publica o anúncio ${ }^{528}$.

Repise-se que o fato de o legislador deixar de mencionar expressamente a orientação sexual como critério proibido de diferenciação, nesses casos, não implica ausência de proteção jurídica ao trabalhador homossexual que seja vítima de

${ }^{525}$ BELMONTE, Alexandre Agra. Responsabilidade por danos morais no Direito do Trabalho. Revista do Tribunal Superior do Trabalho, v. 73, n. 2, p. 25-45, abr./jun. 2007, p. 170. ${ }_{526}$ PEDUZZI, Maria Cristina Irigoyen. Assédio moral. Revista do Tribunal Superior do Trabalho, v. 73, n. 2, p. 25-45, abr./jun. 2007, p. 40.

${ }^{527}$ BRASIL. Decreto-Lei 5.452 (Consolidação das Leis do Trabalho). DOFC, 09/08/1943, p. 11937.

${ }^{528}$ COSTA, Ana Maria Machado da. A discriminação por orientação sexual no trabalho aspectos legais. In: POCAHY, Fernando. (Org.). Rompendo o silêncio: homofobia e heterossexismo na sociedade. Porto Alegre: Nuances, 2007, p. 93. 
discriminação empregatícia, nem impede seja o uso da orientação sexual considerada como espécie do gênero discriminação baseado no parâmetro "sexo"529.

Por conseguinte, é também ilícito o anúncio de emprego que exige do candidato à vaga ofertada uma determinada orientação sexual, visto se tratar de qualidade íntima e privada que nada influi no exercício da atividade.

O mesmo art. 373-A obsta, ainda, em seu inciso II, que o empregador se valha de critérios discriminatórios para recusar emprego ou promoção, bem como motivo para a dispensa de empregado. Esses critérios não podem tampouco ser levados em consideração para fins de remuneração, formação profissional e oportunidade de ascensão profissional, nem para impedir o acesso, inscrição ou aprovação em processos seletivos do empregador (incisos III e V).

Para além das normas celetistas aplicáveis à discriminação empregatícia por orientação sexual, o diploma justrabalhista infraconstitucional mais amplo na abordagem da temática é a Lei 9.029, de 13 de abril de 1995, que, em sua redação original, proíbe expressamente a adoção de práticas discriminatórias "para efeito de acesso a relação de emprego, ou sua manutenção, por motivo de sexo, origem, raça, cor, estado civil, situação familiar ou idade".

De forma a eliminar qualquer dúvida quanto à natureza meramente exemplificava dos critérios de discrímen enumerados, o legislador reformulou o seu art. $1^{\circ}$, por meio da Lei 13.146/2015 (Estatuto da Pessoa com Deficiência), para acrescer novos parâmetros (deficiência e da reabilitação profissional), ao lado da expressão entre outros - abertura essa similar àquela adotada pelo art. $3^{\circ}$, IV da Constituição, que orienta o intérprete no sentindo da aplicabilidade do regime jurídico decorrente da Lei 9.029/1995 também à discriminação empregatícia motivada por orientação sexual.

Debruçando-se sobre as repercussões penais, ${ }^{530}$ administrativas e trabalhistas das condutas discriminatórias na relação de emprego, o legislador

${ }^{529}$ COSTA, Ana Maria Machado da. A discriminação por orientação sexual no trabalho aspectos legais. In: POCAHY, Fernando. (Org.). Rompendo o silêncio: homofobia e heterossexismo na sociedade. Porto Alegre: Nuances, 2007, p. 95.

${ }^{530}$ Cumpre anotar que, no tocante à responsabilidade penal, por força da vedação da analogia in malam partem, consectário do princípio da reserva legal em matéria criminal (art. $5^{\circ}, \mathrm{XXXIX,}$ da CF/1988), os crimes previstos no art. $2^{\circ}$ da Lei $9.029 / 1995$ aplicam-se tão somente às discriminações motivadas por etnia, raça, cor ou deficiência (art. $3^{\circ}$, caput), não podendo abarcar outros critérios de diferenciação para além dos expressamente consignados pelo legislador. Nesse sentido, o ordenamento jurídico brasileiro não dispõe ainda de norma que dê ensejo à responsabilização penal pela prática de discriminação empregatícia por motivo 
abarcou a responsabilidade nas fases pré-contratual e contratual. Muito embora não tenha versado sobre o momento pós-contratual, os eventuais efeitos da discriminação, nessa etapa ${ }^{531}$, não escapam às normas gerais atinentes à responsabilidade civil por danos patrimoniais e extrapatrimoniais, dispostas na Constituição (art. $5^{\circ}, \mathrm{V}$ e X) e no Código Civil (art. 927 e seguintes) $)^{532}$.

Particularmente no que tange à admissão de trabalhadores, é bem verdade que a Constituição assegura a todo empregador a faculdade de decidir quem deseja ou não contratar. No entanto, essa liberdade não é irrestrita, sendo resguardada na medida em que exercida dentro dos limites constitucionais. De um lado, ela deve respeitar as liberdades fundamentais de outras pessoas, incluindo-se aí a autodeterminação em termos da identidade sexual. De outro lado, a liberdade para contratar tem por finalidade assegurar não apenas a propriedade privada, mas também o seu fim social. Nesse sentido, só há exercício regular do direito enquanto circunscrito aos princípios e objetivos adotado pela Constituição, que rechaça discriminações injustas e se guia pelo valor social do trabalho ${ }^{533}$.

A invocação, pelo empregador, de sua liberdade para contratar, como subsídio para a prática de conduta discriminatória que impeça ou limite o ingresso de

de orientação sexual. A bem da verdade, a ausência de criminalização da discriminação homofóbica é geral, não se limitando às práticas concernentes à relação de emprego. Basta ver que o critério é também omitido pela Lei 7.716/1989, que pune os crimes resultantes de discriminação ou preconceito de raça, cor, etnia, religião ou procedência nacional em questões não trabalhistas. Ainda hoje, há uma forte resistência de determinados segmentos políticos com representatividade no Congresso Nacional, notadamente aqueles de inspiração religiosa, a que seja criminalizada qualquer forma de discriminação contra homossexuais, sob o argumento de que, com isso, se poderia colocar em cheque o direito fundamental à liberdade religiosa e de expressão. A movimentação articulada desses setores deu ensejo, inclusive, ao arquivamento definitivo, no Senado Federal, do PLC 122/2006, projeto aprovado pela Câmara dos Deputados que se voltava a definir os crimes resultantes de discriminação ou preconceito de gênero, sexo, orientação sexual ou identidade de gênero. Para maiores informações acerca da dinâmica política em torno da questão, consultar VITAL, Christina; LOPES, Paulo Victor Leite. Religião e política: uma análise da atuação de parlamentares evangélicos sobre direitos das mulheres e de LGBTs no Brasil. Rio de Janeiro: Fundação Heinrich Böll, 2012.

${ }^{531}$ Belmonte cita, como exemplo de conduta ilícita indenizável, na fase pós-contratual, a divulgação, pelo empregador, de informações inverídicas ou depreciativas a respeito do exempregado, restringindo suas possibilidades de acesso ao trabalho. BELMONTE, Alexandre Agra. Responsabilidade por danos morais no Direito do Trabalho. Revista do Tribunal Superior do Trabalho, v. 73, n. 2, p. 25-45, abr./jun. 2007, p. 159.

532 VIANA, Márcio Túlio; PIMENTA, Raquel Betty de Castro. A proteção trabalhista contra os atos discriminatórios (análise da Lei n. 9.029/95). In: RENAULT, Luiz Otávio Linhares; VIANA, Márcio Túlio; CANTELLI, Paula Oliveira (coord.). Discriminação. 2. ed. São Paulo: LTr, 2010, p. $135-136$.

${ }^{533}$ Ibid., p. 136-137. 
determinados indivíduos ao trabalho, em razão de sua orientação sexual, configura abuso de direito, um ato ilícito.

A esse respeito, Viana assevera que:

(...) pior ainda será quando o agente se vale da norma para fins não apenas estranhos a ela, mas proibidos por outra. Nesse caso, o abuso se torna até mais grave do que a violação literal, pois é como se alguém utilizasse do próprio ordenamento jurídico para feri-lo ${ }^{534}$.

É essa a ideia na qual se apoia a Lei 9.029/1995, ao apresentar um rol aberto de critérios que, por sua natureza discriminatória, não se prestam a motivar, mesmo que veladamente, o impedimento ou a limitação do acesso de determinadas pessoas ao trabalho.

A demonstração de que a negativa de admissão se amolda às proibições à discriminação, por conseguinte, torna ilícita a recusa de contratação e dá direito, ao trabalhador discriminado, de pleitear correspondente compensação pelos danos morais que presumidamente decorrem dessa conduta, bem como, caso comprovados, reparação pelos eventuais danos materiais suportados. Vale repisar, ademais, que apesar de não haver ainda relação de emprego nessa hipótese, o mero fato de a conduta ilícita ter sido praticada em função de um possível contrato de trabalho submete o litígio à esfera de atuação da Justiça do Trabalho, tendo em vista o alargamento de sua competência operado pela Emenda Constitucional 45/2004 ${ }^{535}$.

Noutro giro, no que diz respeito ao rompimento do contrato de trabalho por motivação discriminatória, a Lei 9.029/1995 inova ao trazer para o empregado, em seu art. $4^{\circ}$, sem prejuízo da respectiva compensação por danos morais que lhe seja devida, o direito de optar por dois remédios jurídicos contra a dispensa ilícita. Facultase ao trabalhador decidir pela reintegração ao emprego, com ressarcimento integral de todo o período de afastamento, com juros e correção monetária; ou, alternativamente, por uma reparação consistente na percepção, em dobro, da remuneração do período de afastamento, corrigida monetariamente e acrescida dos juros legais.

Adicionalmente, em ocorrendo quaisquer das práticas vedadas no diploma em questão, a Lei 9.029/1995 instituiu, ainda, sanções de natureza administrativa,

\footnotetext{
${ }^{534}$ VIANA, Márcio Túlio; PIMENTA, Raquel Betty de Castro. A proteção trabalhista contra os atos discriminatórios (análise da Lei n. 9.029/95). In: RENAULT, Luiz Otávio Linhares; VIANA, Márcio Túlio; CANTELLI, Paula Oliveira (coord.). Discriminação. 2. ed. São Paulo: LTr, 2010, p. 137.

535 lbid., p. 138.
} 
elencadas em seu art. $3^{\circ}$, sujeitando o empregador que incorre em discriminação empregatícia à multa de dez vezes o valor do maior salário pago, elevado em cinquenta por cento em caso de reincidência; e à proibição de obter empréstimo ou financiamento junto a instituições financeiras oficiais.

O escopo protetivo do ordenamento jurídico trabalhista, sobretudo em face dos múltiplos desdobramentos da discriminação em termos de submissão do sujeito discriminado ao agente discriminador, não se restringem, porém, à dimensão material do Direito.

É bem verdade que, sob uma perspectiva clássica, o processo costuma ser visto como mecanismo neutro para a resolução de litígios, um caminho meramente instrumental, equidistante dos interesses em disputa, que dispensa tratamento formalmente igualitário às partes e, assim, possibilita a justa aplicação do direito. Todavia, como bem enfatiza Mallet, não existe neutralidade no Direito em si. O fenômeno jurídico não é um fim em si mesmo, mas, desde sua gênese atende a interesses e se presta à consecução de objetivos e à realização de valores prédefinidos $^{536}$. Nesse passo, as mudanças sofridas pelo Direito Processual também decorrem do contexto histórico em que são gestadas:

(...) A evolução do direito processual evidencia como as estruturas concretamente adotadas para a tutela dos direitos variam de acordo com os interesses prevalecentes em cada momento histórico, influenciadas pelas forças sociais das distintas épocas ${ }^{537}$.

Nesse sentido, a lei processual trabalhista, sob a égide de uma Constituição democrática e inclusiva, pautada pela dignidade da pessoa humana, não pode dispensar às partes em litígio um tratamento igualitário exclusivamente formal, desconsiderando, desse modo, desigualdades fáticas que influem nas possibilidades individuais para obter a tutela judicial de interesses.

Ao supor como iguais, no plano processual, sujeitos que não o são na realidade, a legislação encobre e intensifica, com uma isonomia ficta, disparidades de condições de acesso à justiça. Por conseguinte, em respeito ao Texto Constitucional de 1988, o Direito Processual do Trabalho, tanto quanto o Direito Material do Trabalho, deve se abrir à uma concepção substancial de igualdade, que não apenas reconheça

\footnotetext{
536 MALLET, Estevão. Discriminação e processo do trabalho. In: RENAULT, Luiz Otávio Linhares; VIANA, Márcio Túlio; CANTELLI, Paula Oliveira (coord.). Discriminação. 2. ed. São Paulo: LTr, 2010, p. 200.

${ }^{537}$ Ibid., p. 200.
} 
a existência de condições não equânimes entre as partes para atuar no processo, mas também disponha de mecanismos normativos que permitam equilibrar essa desigualdade processual concreta, derivada de diferenças fáticas extraprocessuais ${ }^{538}$.

Convergindo para o alargamento dos padrões de reconhecimento no Direito ao qual se volta a Constituição, o uso do discurso metonímico, nesse caso, seja quando da elaboração da lei processual ou de sua interpretação, se presta a contextualizar as especificidades das partes, que as põem em posição privilegiada ou prejudicada em relação ao outro, para fundamentar um tratamento jurídico diferenciado capaz de, na medida do possível, compensar essa desigualdade e equilibrar a atuação dos sujeitos do processo. Essa ideia encontra-se inscrita no Novo Código de Processo Civil, de aplicação supletiva e subsidiária ao Processo do Trabalho (art. 15), que, em seu art. $1^{\circ}$, consigna: "O processo civil será ordenado, disciplinado e interpretado conforme os valores e as normas fundamentais estabelecidos na Constituição da República Federativa do Brasil, observando-se as disposições deste Código".

Feitas essas considerações, destaque-se que um dos mais importantes campos de incidência, no Processo do Trabalho, do princípio protetivo revisitado pela Constituição de 1988 diz respeito à desigualdade das partes envolvidas em casos de discriminação empregatícia, no que toca à produção de provas.

As discriminações e, em especial, a de motivação homofóbica, como já se indicou, são frequentemente praticadas verbalmente no decorrer da relação contratual e, por vezes, não deixam rastros documentais, ou se realizam de forma velada, sem explicitar os motivos que a animam. Ademais, em não havendo obrigação do empregador de declinar as razões pelas quais dispensa ou deixa de contratar alguém, ele se escuda, desse modo, em seu próprio silêncio. Isso implica um ônus excessivo para que o obreiro vítima de discriminação por orientação sexual, parte hipossuficiente na relação, demonstre a veracidade de suas alegações. Daí porque, sustenta Viana, com vistas a impedir que essa dificuldade se converta em um óbice ao direito fundamental de acesso à justiça, o julgador, diante das hipóteses de discriminação empregatícia, deve atribuir um peso maior à prova indiciária e testemunhal, levando

\footnotetext{
538 MALLET, Estevão. Discriminação e processo do trabalho. In: RENAULT, Luiz Otávio Linhares; VIANA, Márcio Túlio; CANTELLI, Paula Oliveira (coord.). Discriminação. 2. ed. São Paulo: LTr, 2010, p. 201-202.
} 
em conta, inclusive, o real significado do silêncio do empregador em declinar as razões que motivam sua conduta ${ }^{539}$.

Ao lado da valoração judicial da prova produzida, a distribuição do ônus probatório é outro fator para o qual o direito processual constitucionalizado, em casos de discriminação, deve atentar.

A CLT, editada em meio a um contexto institucional autoritário que apenas décadas mais tarde seria suplantado pelo paradigma do Estado Democrático de Direito, cuidou da matéria sob uma perspectiva demasiadamente objetiva e ancorada tão somente na percepção formal da igualdade. Pressupondo a paridade de armas entre os litigantes, o art. 818 da CLT assim determinou que "A prova das alegações incumbe à parte que as fizer". Nessa esteira, consagrando uma distribuição estanque do ônus da prova baseada tão somente na autoria da alegação, o legislador fechou os olhos para as condições concretas de cada parte para demonstrar a consistência e a veracidade de sua versão dos fatos ${ }^{540}$.

O rigor do dispositivo foi uma das razões que levou a Justiça do Trabalho, com o passar dos anos, a construir presunções a partir da experiência ordinária, que mitigam a severa imposição ao empregado, elo usualmente hipossuficiente da relação, do dever de provar as alegações que traz aos autos. Nesse sentido, por exemplo, a Súmula 212 do Tribunal Superior do Trabalho (TST) firma o entendimento de que, salvo prova em contrário do empregador, se presume que o término da relação empregatícia configura dispensa sem justa causa ${ }^{541}$.

Considerando-se, a um, as já referidas dificuldades quanto à comprovação de práticas discriminatórias; e, a dois, o fato de que o empregador, pelos documentos e informações à sua disposição, tem maior aptidão para produzir provas, conclui-se que a possibilidade de se proceder à distribuição dinâmica do ônus probatório, nessas hipóteses, é mais consentânea com o atendimento aos princípios isonômico e tuitivo, na seara processual, do que a regra celetista literalmente interpretada. Isto pois, como frisa Mallet, as regras a esse respeito:

\footnotetext{
${ }^{539}$ VIANA, Márcio Túlio; PIMENTA, Raquel Betty de Castro. A proteção trabalhista contra os atos discriminatórios (análise da Lei n. 9.029/95). In: RENAULT, Luiz Otávio Linhares; VIANA, Márcio Túlio; CANTELLI, Paula Oliveira (coord.). Discriminação. 2. ed. São Paulo: LTr, 2010, p. 138.

540 MALLET, Estevão. Discriminação e processo do trabalho. In: RENAULT, Luiz Otávio Linhares; VIANA, Márcio Túlio; CANTELLI, Paula Oliveira (coord.). Discriminação. 2. ed. São Paulo: LTr, 2010, p. 203.

${ }^{541}$ Ibid., p. 204.
} 
(...) hão de levar em conta sempre as possibilidade, reais e concretas, que tem cada litigante de demonstrar suas alegações, de tal modo que recaia esse ônus não necessariamente sobre a parte que alega, mas sobre a parte que se encontra em melhores condições de produzir a prova necessária à solução do litígio ${ }^{542}$.

Foi esse o caminho trilhado pela legislação consumerista pós-1988, estabelecendo o Código de Proteção e Defesa do Consumidor (Lei 8.078/1990) a possibilidade de inversão do ônus da prova, em benefício do consumidor, se "for verossímil a alegação ou quando for ele hipossuficiente, segundo as regras ordinárias de experiências" (art. $\left.6^{\circ}, \mathrm{VIII}\right)$.

A possibilidade de inversão do ônus probatório, no Processo do Trabalho, era até muito recentemente uma questão ainda controvertida. Mallet, por exemplo, sustenta que a distribuição estanque do ônus da prova, segundo um critério de igualdade formal, só poderia ser superado efetivamente por meio de alteração legislativa do dispositivo celetista ${ }^{543}$. Há julgados, porém, que se embasavam no CDC para, reconhecendo a condição de hipossuficiência do trabalhador, distribuir de forma diversa o ônus probatório ${ }^{544}$.

Não obstante, o advento do novo Código de Processo Civil (Lei 13.105/2015) tende a pacificar a questão, na medida em que prevê:

Art. 373. O ônus da prova incumbe:

I - ao autor, quanto ao fato constitutivo de seu direito;

II - ao réu, quanto à existência de fato impeditivo, modificativo ou extintivo do direito do autor.

$\S 1^{\circ}$ Nos casos previstos em lei ou diante de peculiaridades da causa relacionadas à impossibilidade ou à excessiva dificuldade de cumprir o encargo nos termos do caput ou à maior facilidade de obtenção da prova do fato contrário, poderá o juiz atribuir o ônus da prova de modo diverso, desde que o faça por decisão fundamentada, caso em que deverá dar à parte a oportunidade de se desincumbir do ônus que lhe foi atribuído.

$\S 2^{\circ} \mathrm{A}$ decisão prevista no $\S 10$ deste artigo não pode gerar situação em que a desincumbência do encargo pela parte seja impossível ou excessivamente difícil.

542 MALLET, Estevão. Discriminação e processo do trabalho. In: RENAULT, Luiz Otávio Linhares; VIANA, Márcio Túlio; CANTELLI, Paula Oliveira (coord.). Discriminação. 2. ed. São Paulo: LTr, 2010, p. 203.

${ }^{543}$ Ibid., p. 204.

544 Nesse sentido: BRASIL. Tribunal Superior do Trabalho. Ag-AIRR 2950063.2009.5.02.0019, Relator Ministro: Emmanoel Pereira, Data de Julgamento: 07/05/2014, $5^{\text {a }}$ Turma, Data de Publicação: DEJT 16/05/2014. 
O Tribunal Superior do Trabalho, procedendo à análise da novel legislação processual civil, editou a Instrução Normativa 39/2016, na qual opinou pela aplicabilidade da distribuição dinâmica do ônus probatório ao Processo do Trabalho, nos termos em que implementada pelo NCPC — à exceção dos $\S \S 3^{\circ} \mathrm{e} 4^{\circ}$, que cuidam da distribuição diferenciada do ônus por convenção das partes, por incompatibilidade com as regras e princípios protetivos que orientam o Direito do Trabalho ${ }^{545}$.

Ao fim e ao cabo, sob a ótica do Direito do Trabalho constitucionalizado, em suas dimensões material e processual, a dispensa de tratamento discriminatório a homossexuais, no âmbito das relações empregatícias, é conduta não apenas contrária aos princípios e valores que orientam o ordenamento jurídico brasileiro, mas também vedada e sancionada pelos três eixos normativos que conferem densidade ao direito fundamental do trabalho digno.

\subsection{0 papel da Justiça do Trabalho na construção do discurso constitucional trabalhista: o Tribunal Superior do Trabalho e a discriminação empregatícia por orientação sexual}

Buscou-se construir, até aqui, um quadro minimamente coerente sobre a forma como o ordenamento jurídico brasileiro, sob a égide da Constituição Federal de 1988 e a perspectiva do direito fundamental ao trabalho digno, aborda as questões relativas à discriminação por orientação sexual perpetrada na dinâmica das relações de emprego - um fenômeno social que, como explorado no capítulo 2 desta pesquisa, reproduz padrões culturais de exclusão e se manifesta sob uma grande variedade de formas, das mais evidentes às mais veladas, resultando em prejuízos de ordem tanto patrimonial quanto extrapatrimonial para suas vitimas.

Nesse percurso, apontou-se a existência de um preceito isonômico, diretamente emanado da dignidade da pessoa humana, com assento nas esferas internacional, constitucional e infraconstitucional. Na qualidade de direito humano e fundamental, essa igualdade substancial reclama a adoção de sanções jurídicas e medidas preventivas em face de condutas discriminatórias que, tomando por base critérios proibidos de diferenciação, impliquem óbices ao reconhecimento ou ao exercício de direitos em igualdade de oportunidades.

\footnotetext{
${ }^{545}$ BRASIL. Tribunal Superior do Trabalho. Resolução n. 203, de 15 de março de 2016 [Instrução Normativa n. 39]. Diário Eletrônico da Justiça do Trabalho, Brasília, DF, n. 1939, 16 mar. 2016. Caderno Judiciário do Tribunal Superior do Trabalho, p. 1-4.
} 
Essa diretriz estende-se também ao Direito do Trabalho, notadamente no que tange à igualdade de oportunidades e de tratamento em matéria de emprego, como pressuposto de realização do direito fundamental ao trabalho digno.

O caráter aberto e flexível, porém, desse rol de critérios que, quando utilizado, faz incidir a disciplina jurídica do conjunto de normas contra a discriminação, remete ao discurso constitucional a tarefa de, por um esforço construtivo e reconstrutivo, definir a abrangência do comando isonômico, especificando as diferenciações aceitas ou rechaçadas pela Constituição - e, no caso específico, elucidar se o Texto Constitucional compactua com discriminações pautadas na orientação sexual, no âmbito das relações de emprego.

Viu-se, de todo modo, que o texto constitucional de 1988, por sua natureza inclusiva, orienta o intérprete no sentido da ampliação dos padrões de reconhecimento, bem como da extensão da tutela protetiva a grupos socialmente estigmatizados, como os homossexuais. Nesse sentido, a coerência do discurso constitucional seria mantida apenas se considerada a orientação sexual também como um critério proibido de diferenciação. Uma interpretação excludente, afinal, não conseguiria superar o filtro da negação ${ }^{546}$, por contrariar princípios fundamentais do projeto constitucional, notadamente a dignidade da pessoa humana e o pluralismo.

É pertinente voltar os olhos, portanto, às instâncias que, na estrutura do Estado brasileiro, gozam de competência e legitimidade institucional para proceder à (re)construção do discurso constitucional trabalhista, sobretudo para densificar o conteúdo do princípio protetivo que rege o Direito do Trabalho.

Nesse quadro, cumpre notar que "a Justiça do Trabalho é considerada um dos mais sólidos e democráticos instrumentos jurídicos e institucionais para a concretização da dignidade do ser humano e dos direitos fundamentais nos conflitos de interesse" 547 .

O Tribunal Superior do Trabalho, em particular, tem um notável protagonismo nesse contexto, em se tratando de órgão de cúpula da jurisdição trabalhista, expressamente imbuído de competência para a uniformização do discurso constitucional, no âmbito da justiça especializada.

\footnotetext{
${ }^{546}$ ROSENFELD, Michel. A identidade do sujeito constitucional. Tradução de Menelick de Carvalho Netto. Belo Horizonte: Mandamentos: 2003.

547 DELGADO, Maurício Godinho; DELGADO, Gabriela Neves. 70 anos da Justiça do Trabalho. Revista do Tribunal Superior do Trabalho, Brasília, vol. 77, n. 2, abr./jun. 2011, p. 114.
} 
A Corte Trabalhista é, portanto, um dos principais articuladores da identidade constitucional trabalhista e, fazendo uso dos recursos linguísticos da negação, da metáfora e da metonímia, desincumbe-se da atribuição de costurar o tênue equilíbrio entre o eu e o outro nas relações de trabalho, promovendo, assim, o ideal de democracia plural e inclusiva abraçado pela Constituição da República de 1988.

Foi esse o olhar que conduziu a pesquisa nas bases de jurisprudência da Corte Superior Trabalhista, mediante o levantamento e a análise de acórdãos proferidos em ações propostas por empregados, sob a alegação de terem sido vítimas de alguma forma de discriminação por orientação sexual.

Para tanto, procedeu-se a um recorte temporal, considerando os acórdãos publicados no interstício entre 31 de dezembro de 2004 e 6 de abril de 2016. A imposição desse limite se fez necessária, pois a promulgação da Emenda Constitucional 45/2004, ao promover uma ampla reforma do Poder Judiciário, aperfeiçoou notadamente a Justiça do Trabalho. De uma só vez, fortalecendo-a institucionalmente na defesa dos direitos fundamentais trabalhistas, o constituinte ampliou a competência temática da Justiça do Trabalho para além da relação de emprego (espécie), passando a abranger controvérsias as mais diversas decorrentes das relações de trabalho (gênero), e retomou a composição do Tribunal Superior do Trabalho com 27 ministros, outrora reduzida em 10 integrantes, quando da extinção da representação classista pela Emenda Constitucional 24/1999548.

Nessa esteira, somente com a promulgação da Emenda Constitucional 45/2004, o art. 114 da Constituição foi modificado para fazer constar expressamente a competência da Justiça do Trabalho para processar e julgar as ações em que se discutam danos materiais ou morais oriundos da relação de trabalho (inciso VI) ${ }^{549}$ uma das principais matérias submetidas à apreciação judicial, no que toca à discriminação empregatícia por orientação sexual.

Quanto às classes processuais pesquisadas, tomou-se como norte o recurso de revista, por se tratar de espécie recursal para a qual a CLT, em seu art. 896, institui, como hipóteses de cabimento, ofensas à lei federal e à Constituição. Nesse rumo, foram considerados os acórdãos proferidos nas classes Recurso de Revista, Agravo

${ }^{548}$ DELGADO, Maurício Godinho; DELGADO, Gabriela Neves, Tratado jurisprudencial de direito constitucional do trabalho. São Paulo: Editora Revista dos Tribunais, 2013, p. 7-8. ${ }^{549}$ BELMONTE, Alexandre Agra. Responsabilidade por danos morais no Direito do Trabalho. Revista do Tribunal Superior do Trabalho, v. 73, n. 2, p. 25-45, abr./jun. 2007, p. 169. 
de Instrumento em Recurso de Revista e Agravo em Agravo de Instrumento em Recurso de Revista (RR, ARR ou AIRR e Ag-AIRR).

$\mathrm{Na}$ fase de delimitação temática, a pesquisa jurisprudencial ateve-se ao próprio critério de diferenciação que fora objeto de estudo nos capítulos precedentes, a orientação sexual. Nesse passo, valendo-se da ferramenta de Consulta Unificada, disponível no sítio eletrônico do Tribunal Superior do Trabalho ${ }^{550}$, lançaram-se, no campo de pesquisa por ementa, as seguintes expressões: homossex $\$^{551}$, orientação sexual e opção sexual. Esses termos retornaram 34 acórdãos, dos quais 2 foram excluídos por não guardarem pertinência temática para com a matéria buscada (discriminação por orientação sexual).

Complementarmente, em uma segunda etapa, foi utilizado como critério de pesquisa a expressão sexualidade, obtendo-se 5 acórdãos sobre a matéria, dos quais apenas 1 foi excluído, por já constar da primeira busca realizada. A terceira etapa, finalmente, valeu-se do operador homofobia, levantando 3 julgados, dos quais se eliminou 1, por falta de pertinência temática.

Da soma das três etapas de pesquisa jurisprudencial, contabilizaram-se, portanto, 38 julgados do Tribunal Superior do Trabalho em que se constataram alegações de obreiros relacionadas à discriminação por orientação sexual (conhecida, presumida ou insinuada).

A partir do exame desse conjunto de julgados, catalogaram-se os seguintes dados, em tabela do programa Excell: (A) Número do processo; (B) Data de publicação do acórdão; (C) Gênero do(a) reclamante; (D) Tipo de discriminação alegada; (E) Tema do Recurso de Revista; (F) Dispositivo; e (G) Valor da indenização por danos morais ${ }^{552}$.

Os dados compilados na tabela foram, então, lançados no serviço de planilhas on-line da Google, o Google Sheets ${ }^{553}$, usado para gerar três gráficos ilustrativos dos resultados desta pesquisa de jurisprudência, com parte das informações coletadas.

Anote-se que foram compilados dados relativos à discriminação empregatícia por orientação sexual sofrida por trabalhadores de ambos os sexos, visto que, a despeito das diferenças na origem sociocultural e nas formas como se manifestam as

\footnotetext{
${ }^{550}$ Disponível em <http://www.tst.jus.br/consulta-unificada>.

${ }^{551}$ No sistema de consulta unificada do TST, o operador \$ pode substituir qualquer parte da palavra digitada, seja ela sufixo, prefixo ou mesmo o radical.

${ }^{552}$ Consultar Apêndice.

${ }^{553}$ Disponível em: <https://www.google.com/sheets/about/>. Acesso em 06/04/2016.
} 
homofobias em relação a homens e mulheres ${ }^{554}$, na perspectiva jurídica, a disciplina normativa e os princípios embasadores da proibição a esse tipo específico de discriminação são idênticos, independentemente do sexo biológico ou gênero da vítima.

\subsubsection{Análise de resultados}

A partir do levantamento e da análise dos acórdãos do TST, a pesquisou debruçou-se de início sobre a verificação do possível gênero dos trabalhadores cujos processos chegam, em grau de recurso, à cúpula da Justiça do Trabalho, tendo por objeto o tema da discriminação empregatícia por orientação sexual. $\mathrm{Na}$ falta de maiores informações sobre esse aspecto, foram considerados, para se deduzir o gênero do reclamante, apenas o nome constante do cadastro processual e o gênero pelo qual o julgado faz referência às partes.

E, nesse específico, ficou evidente uma ampla desproporção na distribuição dos reclamantes entre os gêneros masculino e feminino.

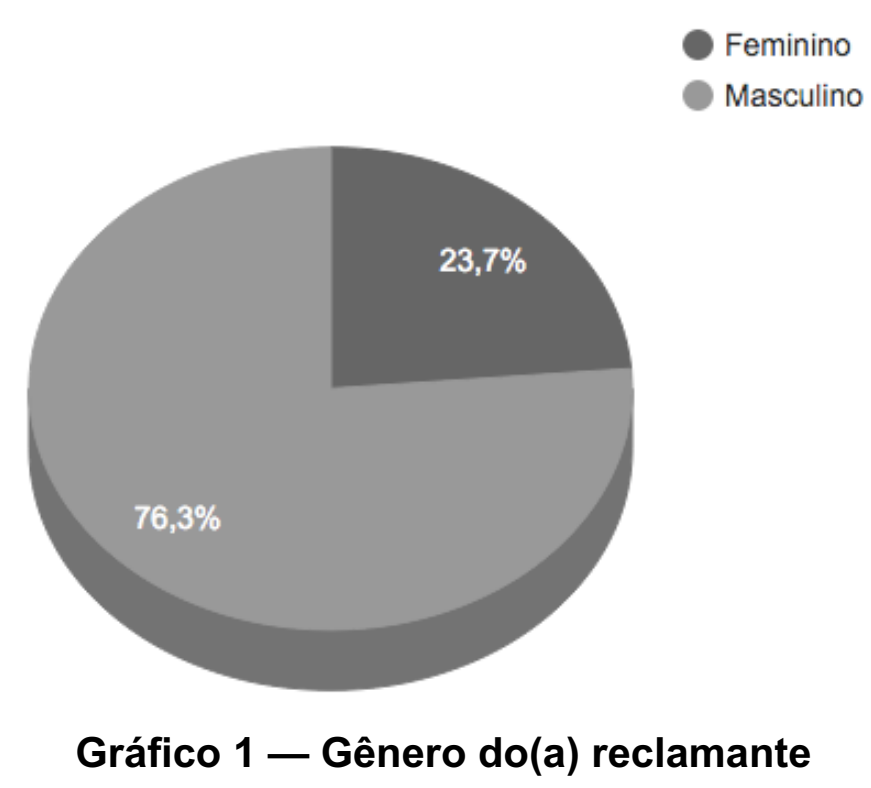

Como se depreende do Gráfico 1, em 76,3\% dos casos de discriminação por orientação sexual julgados pelo TST, em grau de recurso de revista, os reclamantes são homens e, em apenas $23,7 \%$, mulheres. Por conta da ausência de maiores informações, sobretudo quanto aos índices de propositura de ações em primeira instância por gêneros, e tendo em vista ainda o número restrito de recursos sobre o

${ }^{554}$ A esse respeito, consultar os Capítulos 1 e 2. 
tema em discussão, não se pode afirmar, porém, uma tendência de que homens acionem a Justiça do Trabalho com maior frequência, quando sofrem discriminação por orientação sexual em matéria de emprego.

Vale lembrar, entretanto, que os preconceitos homofóbicos contra homens ou mulheres homossexuais operam de maneiras distintas, na medida em que há um cruzamento das categorias gênero e orientação sexual na conformação desses fenômenos. A transgressão à masculinidade que a identidade homossexual simbolicamente representa tende a gerar, no sistema social de dominação masculina, forte reação pública de desprezo, sobretudo por parte da comunidade dos homens. Lésbicas, por sua vez, também se sujeitam, enquanto mulheres, à objetificação e à anulação de sua sexualidade pelo sistema androcêntrico, sendo invisibilizadas ${ }^{555}$.

Embora essa ponderação não forneça uma explicação definitiva para a clivagem de gênero nos processos julgados pelo TST, é uma das possíveis razões para a maior expressividade, no âmbito judicial, das ações movidas por reclamantes do sexo masculino, em que se discute a discriminação por orientação sexual.

Já no que toca aos tipos de discriminação alegados pelos reclamantes, o Gráfico 2 demonstra que o assédio moral, confirmado pelo TST na maioria dos recursos, é a violação mais frequente $(55,26 \%$ dos casos) e que também se traduz na prática reiterada das outras modalidades elencadas. Destacam-se igualmente o humor vexatório $(47,37 \%)$ e as ofensas $(47,37 \%)$, condutas discriminatórias usualmente verbais que, como se viu no Capítulo 2, estão entre as mais relatadas pelos trabalhadores ${ }^{556}$.

Anote-se que alguns acórdãos, ao aludir à ocorrência de prática discriminatória, não especificam a conduta efetiva praticada. Essas hipóteses foram reunidas, por conseguinte, sob a categoria genérica discriminação.

\footnotetext{
555 IRIGARAY, Hélio Arthur Reis; FREITAS, Maria Ester de. Sexualidade e organizações: estudo sobre lésbicas no ambiente de trabalho. Organ. Soc., Salvador, v. 18, n. 59, p. 625641, dez. 2011, p. 630.

${ }^{556}$ SOUZA JÚNIOR, Armando Araújo de; et al. Aspectos da dominação masculina no assédio moral ao profissional homossexual no polo industrial de Manaus. Revista Pensamento \& Realidade, v. 28, n. 1, p. 83-102, 2013, p. 98.
} 


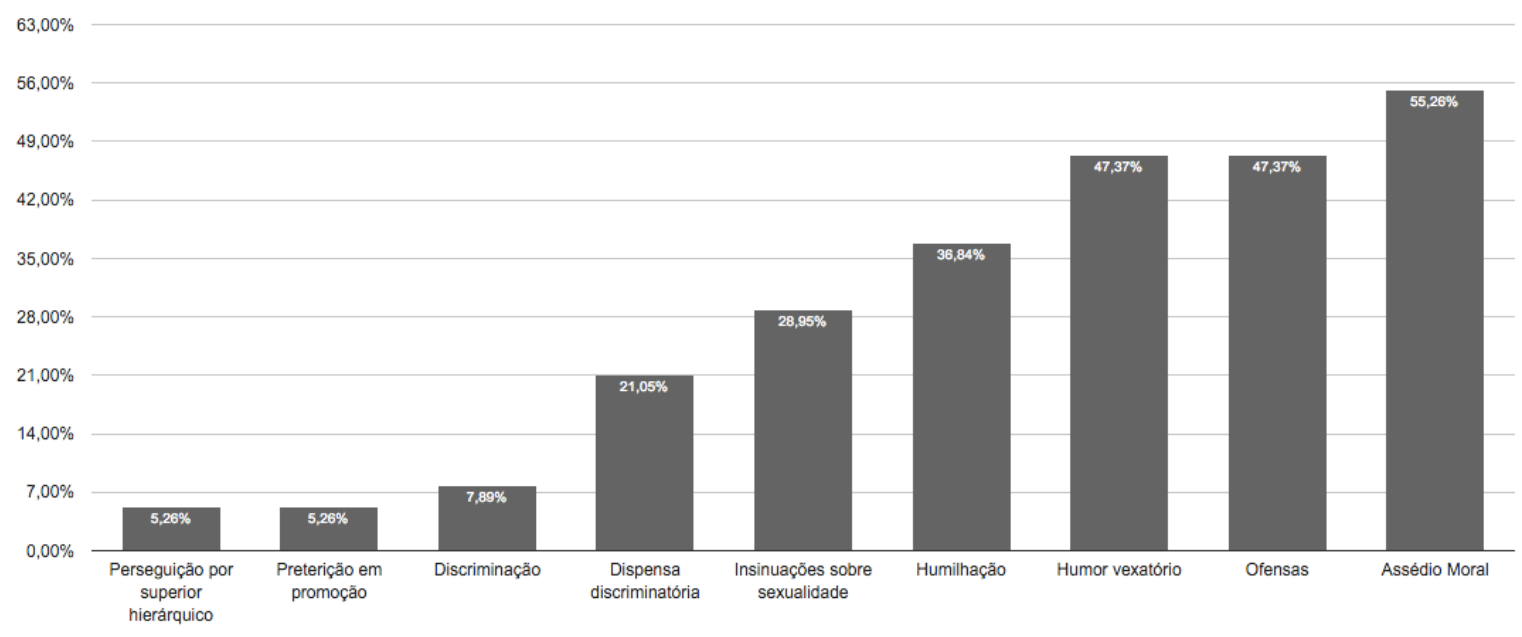

Gráfico 2 - Tipos de discriminação alegada

Recorde-se que, segundo uma visão heteronormativa, o empregado ideal, sério, comprometido com a organização empresarial e eficiente no cumprimento de suas tarefas, é homem e heterossexual ${ }^{557}$. Manifestações dessa concepção que visa a desqualificar o homossexual para o trabalho constam do registro fático elaborado por alguns Tribunais Regionais do Trabalho (TRTs) e replicado pelos acórdãos do TST.

No AIRR-61600-60.2013.5.17.0004, por exemplo, em que se discute o valor da indenização por danos morais decorrente de assédio moral por orientação sexual, o TRT da $17^{\text {a }}$ Região enfatiza:

Constatou-se, por meio dos elementos probatórios dos autos, que 'a condição homossexual do autor é autoevidente e decerto para ele não é desonroso ser gay, mas a menção pejorativa a esse estado por uma superior hierárquica, no sentido de atribuir-lhe menor capacidade do que um empregado heterossexual, é que configura em definitivo um decréscimo moral indelével $(\ldots)^{1558}$.

Em situação semelhante, no AIRR - 3404100-20.2002.5.21.0900, referente ao direito de reintegração ao emprego, em face de dispensa discriminatória, consignouse que:

A dispensa se concretizou após uma avaliação que, na verdade, operou-se em desvio de finalidade ou simulação. Ao desagrado da condição pessoal de homossexual do empregado e sem ousar dar-lhe esta configuração, o empregador procurou desqualificar seu trabalho.

\footnotetext{
${ }^{557}$ MCGINLEY, Ann C. Creating masculine identities: bullying and harassment "because of sex". University of Colorado Law Review, v. 79, 2008, p. 1161-1162.

558 BRASIL. Tribunal Superior do Trabalho. AIRR - 61600-60.2013.5.17.0004, Relator Ministro: Guilherme Augusto Caputo Bastos, Data de Julgamento: 15/04/2015, $5^{\text {a }}$ Turma, Data de Publicação: DEJT 24/04/2015.
} 
Um simulacro de avaliação que, ao pretexto de maior justiça, foi participativa e, assim, até os recém-admitidos e, pois, com o mesmo tempo de serviço do autor, foi feita. $E$ foi obtido o resultado desejado: o reclamante não era apto para o trabalho. O preconceito vencia a questão e o fazia sob o rótulo da falta de qualificação do empregado. Para quem lida com questões do gênero, este circunlóquio é conhecido: não é por ser homossexual, mas... e aí é declinado o pretexto, já que o real motivo está na primeira frase, adversa ${ }^{559}$.

Diante de todos os tipos de alegação, faz-se premente destacar a adesão, nos julgados do Tribunal Superior do Trabalho, a um discurso metonímico no sentido de que as discriminações empregatícias por orientação sexual violam a dignidade da pessoa humana e os direitos fundamentais que dela emanam, como a intimidade, a honra e a vida privada. Mesmo os julgados que afastam a condenação não infirmam esse posicionamento, visto que se amparam em outros fundamentos para reformar a decisão regional, como a necessidade de abertura da instrução probatória, em se verificando cerceamento de defesa ${ }^{560}$.

Tome-se, a título de exemplo, caso examinado pela Sexta Turma do TST, quanto à possibilidade de majoração da condenação por danos morais fixada pelo TRT da $10^{\mathrm{a}}$ Região $^{561}$. Consoante o quadro fático firmado pelo tribunal de origem, durante aproximadamente sete meses, o reclamante, um empregado homossexual, foi vítima de assédio moral, sujeitando-se a condutas aviltantes de outros trabalhadores direcionadas à sua orientação sexual, como ofensas, comentários jocosos e humilhações públicas. Sobre o acontecido, a Corte Regional destacou que "os fatos se davam na presença de terceiros, chegando, inclusive, a deixar as outras pessoas constrangidas, em face do teor dos xingamentos: 'cachorra, puta, vadia vagabunda'" - ofensas estas usadas "no feminino, pois sabia o preposto da agravada que o agravante é homossexual".

Ao analisar recurso de revista do reclamante, o colegiado decidiu pela majoração do valor arbitrado para os danos morais, argumentando que:

Ficou provado que o reclamante, em razão de sua orientação sexual, sofria tratamento intensamente constrangedor, humilhante e vexatório

559 BRASIL. Tribunal Superior do Trabalho. AIRR - 3404100-20.2002.5.21.0900, Relator Ministro: Walmir Oliveira da Costa, Data de Julgamento: 16/12/2009, $1^{\text {a }}$ Turma, Data de Publicação: DEJT 05/02/2010.

${ }^{560}$ BRASIL. Tribunal Superior do Trabalho. RR - 257440-71.2002.5.02.0372, Relator Ministro: Hugo Carlos Scheuermann, Data de Julgamento: 03/02/2016, $1^{\text {a }}$ Turma, Data de Publicação: DEJT 12/02/2016.

561 BRASIL. Tribunal Superior do Trabalho. RR - 129-73.2012.5.10.0812, Relatora Ministra: Kátia Magalhães Arruda, Data de Julgamento: 02/12/2015, 6 ${ }^{\mathrm{a}}$ Turma, Data de Publicação: DEJT 04/12/2015. 
no ambiente de trabalho; o empregado recebia tratamento grosseiro, pejorativo e com xingamentos impublicáveis por parte do seu chefe, cujo assédio ocorria "de forma indecente e imoral", inclusive na presença de terceiros, como no refeitório da empresa; uma das testemunhas presenciou até o preposto "passar a mão nas partes íntimas do reclamante"; havia "extrapolação no que diz respeito ao comportamento comissivo do preposto da reclamada, superior hierárquico, que, em conduta repugnante, libidinosa, constrangedora, adentrou na esfera da liberdade do reclamante, com gracejos indesejosos, inoportunos e inconvenientes, com repercussões na saúde anímica do autor".

No caso dos autos, extremamente grave, devem ser afastados os fundamentos assentados pelo TRT ao reduzir o montante da indenização fixado na sentença, especialmente os aspectos invocados pela Corte regional de que o vínculo de emprego durou aproximadamente sete meses e o salário do reclamante era de $\mathrm{R} \$$ 622,00 . Com efeito, a submissão do trabalhador durante sete meses a intenso assédio moral, e mesmo a repugnante constrangimento físico, inclusive diante dos colegas de trabalho em local de grande circulação de pessoas como o refeitório, aliado à baixa remuneração que certamente inibia a resistência ao tratamento ostensivamente hostil, sob pena de mais retaliações ou mesmo de perda do emprego, são dados que devem ser considerados para a majoração do montante: eis um caso em que a dignidade da pessoa humana é aviltada em nível tão drástico, em reiteradas situações de humilhação extrema, que o trabalhador é atingido profunda e simultaneamente em sua intimidade, vida privada, honra e imagem pessoal e profissional.

Em 2012, a Turma já havia decidido, sob a perspectiva da valorização do trabalho humano (art. $1^{\circ}$, IV, da Constituição), pela condenação de empregador que não se desincumbiu de sua responsabilidade pela manutenção de um ambiente de trabalho equilibrado, sem qualquer conduta discriminatória que tenha em mira a orientação sexual do trabalhador ${ }^{562}$

Posição semelhante vem sendo adotada quando a Corte Trabalhista examina dispensas discriminatória motivadas por orientação sexual:

AGRAVO DE INSTRUMENTO. RECURSO DE REVISTA. DISPENSA
ARBITRÁRIA. DANO MORAL. DISCRIMINAÇÃO SEXUAL.
REEXAME DE FATOS E PROVAS. A Corte de origem, valorando o
conjunto fático-probatório dos autos, concluiu que ficou demonstrado
que a dispensa do reclamante se deu em razão de prática
discriminatória decorrente de sua opção sexual, motivo que, não
bastasse estar totalmente desvinculado do liame jurídico que une
empregado e empregador por meio do contrato de trabalho, revela-se
violador dos direitos personalíssimos do ser humano, o qual encontra
sua máxima expressão na liberdade de escolha, entre a qual se insere
a de definir, livremente, a opção sexual. Nesse contexto, para se

562 BRASIL. Tribunal Superior do Trabalho. RR - 128600-30.2006.5.04.0022, Relator Ministro: Mauricio Godinho Delgado, Data de Julgamento: 07/03/2012, 6 ${ }^{a}$ Turma, Data de Publicação: DEJT 16/03/2012. 
concluir de forma diversa, no sentido de que não foi adotada pela reclamada nenhuma conduta violadora da dignidade da pessoa humana, seria imprescindível a reapreciação da prova coligida aos autos, procedimento vedado, nesta fase recursal de natureza extraordinária, a teor da Súmula $\mathrm{n}^{\circ} 126$ do TST. Agravo de instrumento a que se nega provimento ${ }^{563}$.

O reconhecimento de que os ataques voltados à orientação sexual de um empregado atingem seu valor intrínseco, enquanto pessoa humana, é uma etapa crucial para que se possa compreender a homossexualidade como critério proibido de discriminação, à luz da Constituição, e assim fazer incidir, nessas hipóteses, a disciplina normativa especialmente elaborada para o combate às discriminações.

Isso implica a possibilidade de se invocar a tutela da Lei 9.029/1995, quando a discriminação por orientação sexual afetar o acesso ao trabalho ou a permanência da relação de emprego. Sobre a aplicabilidade da norma, aliás, a $2^{\mathrm{a}}$ Turma, ao julgar um recurso de revista sobre dispensa discriminatória de empregado homossexual, consignou que:

(...) a Lei $9.029 / 95$, em seu art. $1^{\circ}$, contém descrição que se entende meramente exemplificativa, sem esgotar as hipóteses. Assim, a dispensa levada a efeito em face da opção sexual do Reclamante, embora não expressamente inserida na exemplificação legal, constitui também situação ensejadora da indenização prevista no art. $4^{\circ}$, II, daquela lei, o qual não pode ser tido como vulnerado em face disso. Violação legal não configurada. Recurso de Revista não conhecido ${ }^{564}$.

O discurso inclusivo que se vem construindo no Tribunal, entretanto, em relação à diversidade sexual, confere pouco relevo às normas internacionais de direitos humanos sobre discriminação. Escapando a essa tendência, registrou-se um julgado da Segunda Turma, enfatizando que "o Brasil é signatário da Convenção 111 da OIT, a qual proíbe qualquer espécie de discriminação no trabalho em razão de opção sexual" ${ }^{\prime 565}$.

Por derradeiro, o valor das indenizações por danos morais é outro aspecto a se atentar. O Gráfico 3 foi gerado apenas com os processos em que a condenação por danos morais foi mantida ou firmada pela própria Corte Trabalhista, em valor fixo.

563 BRASIL. Tribunal Superior do Trabalho. AIRR - 74240-53.2002.5.02.0019, Relator Ministro: Walmir Oliveira da Costa, Data de Julgamento: 09/02/2011, $1^{\text {a }}$ Turma, Data de Publicação: DEJT 18/02/2011.

${ }^{564}$ BRASIL. Tribunal Superior do Trabalho. RR - 101900-52.2004.5.05.0024, Relator Ministro: José Simpliciano Fontes de F. Fernandes, Data de Julgamento: 15/04/2009, $2^{\mathrm{a}}$ Turma, Data de Publicação: DEJT 09/10/2009

565 BRASIL. Tribunal Superior do Trabalho. RR - 230581-05.2010.5.05.0000, Relatora Ministra: Delaíde Miranda Arantes, Data de Julgamento: 05/08/2015, 2a Turma, Data de Publicação: DEJT 14/08/2015. 
Logo, foram desconsideradas os casos sem condenação por danos morais, as ações em que o valor dos danos não foi informado pelo acórdão e aquelas em que a condenação foi cumulada com danos materiais ou calculada em salários mínimos.

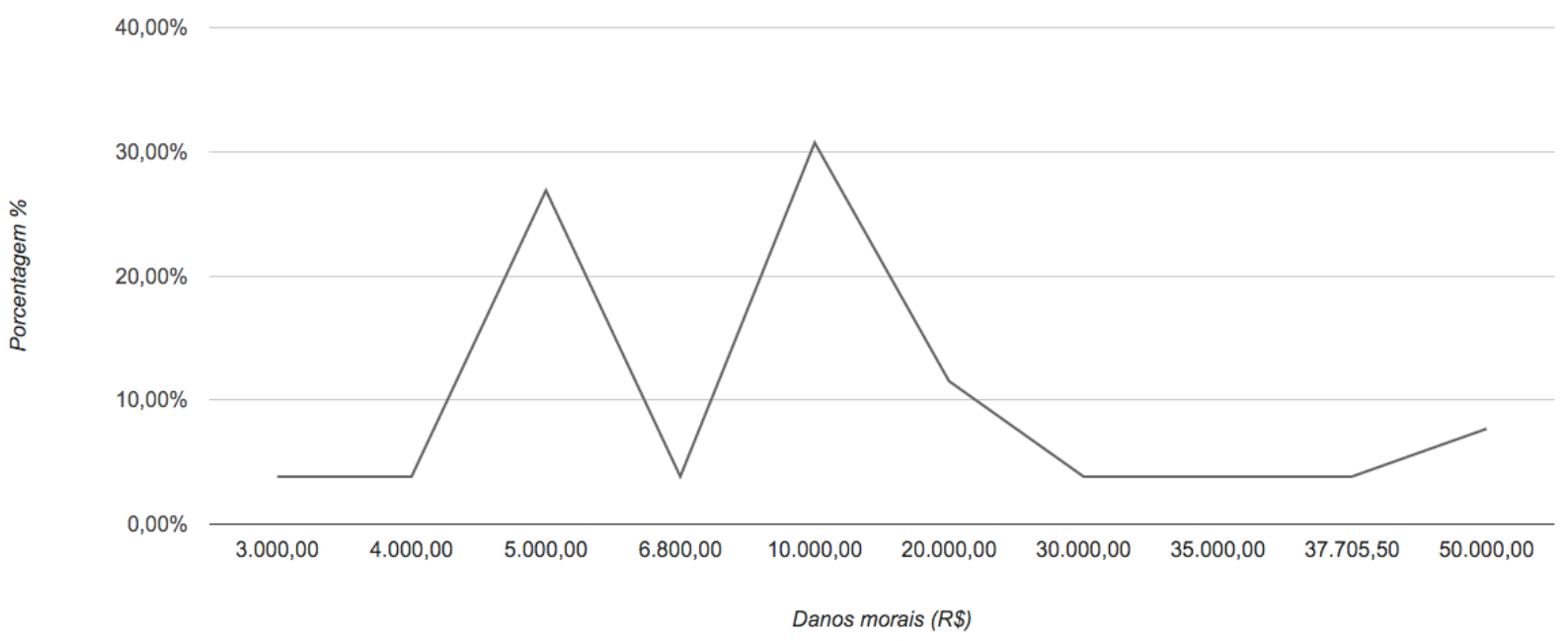

\section{Gráfico 3 - Curva de indenizações por danos morais}

Nesse específico, fica evidente a falta de um critério objetivo para o arbitramento das quantias destinadas a compensar a lesão extrapatrimonial: os valores vão de $R \$ 3.000,00$ a $R \$ 50.000,00$, em situações aparentemente semelhantes. Observou-se também que a grande maioria das indenizações por danos morais não é fixada em patamar muito expressivo, transitando principalmente entre os montantes de $\mathrm{R} \$ 5.000,00$ (26,88\%) e $\mathrm{R} \$ 10.000$ (30,72\%).

Outrossim, a manutenção das condenações dentro dos mesmos patamares nominais, ao longo de um período de 10 anos, revela que o TST tende a desconsiderar os efeitos da inflação sobre o potencial reparador desses valores. Com efeito, uma indenização de $\mathrm{R} \$ 10.000,00$ deferida em 2006 não equivale, em termos de compensação à lesão sofrida, a outra indenização também de $\mathrm{R} \$ \mathbf{1 0 . 0 0 0 , 0 0}$ concedida no ano de 2016.

Em geral, no que toca ao arbitramento da compensação por danos morais nos casos catalogados, os Tribunais Regionais do Trabalho e, bem assim, o TST, sustentam pautar-se pelos critérios de gravidade e repercussão dos danos, condição 
socioeconômica do ofensor e do ofendido, e pelo princípio da proporcionalidade; atentando ainda às funções reparatórias, punitivas e pedagógicas do danos morais ${ }^{566}$. É digno de nota, porém, acórdão da Sétima Turma do TST em processo sobre assédio moral de viés homofóbico, insurgindo-se contra o uso desmedido do argumento da capacidade econômica das partes e da vedação ao enriquecimento ilícito, como forma de manter desproporcionalmente baixo o valor das indenizações por danos morais. Nesse específico, a Corte consignou que:

(...) em consonância com a atual sistemática da reparação civil, em sede de quantificação, deve o julgador observar o próprio dano em si e suas consequências na esfera subjetiva do ofendido (aspectos existenciais, não econômicos) para, então, compor a efetiva extensão dos prejuízos sofridos. E como dito desde o início, sempre norteado pelos princípios da reparação integral e da dignidade humana epicentro da proteção constitucional.

Com efeito, a discussão em torno da reparabilidade e do arbitramento dos danos morais produz consequências que vão muito além do debate entre as partes diretamente envolvidas. De maneira subjacente, identifica-se até mesmo um interesse da comunidade, a fim de que não permaneça o empregador no mesmo comportamento verdadeiramente depreciativo em relação ao valor da vida humana ${ }^{567}$.

De fato, o discurso constitucional trabalhista precisa voltar os olhos mais para os impactos subjetivos da discriminação por orientação sexual na dinâmica das relações de emprego, do que às circunstâncias econômicas das partes envolvidas no litígio judicial. Esta é, aliás, como se destacou anteriormente, uma exigência do princípio protetivo revisitado pela Constituição de 1988. Só assim pode ser compreendida, afinal, a real dimensão, para o trabalhador discriminado, da negativa de seu reconhecimento no trabalho, em função da orientação sexual estigmatizada.

\footnotetext{
566 Nesse sentido, por exemplo: BRASIL. Tribunal Superior do Trabalho. RR - 329061.2011.5.12.0007, Relator Ministro: Márcio Eurico Vitral Amaro, Data de Julgamento: 06/08/2014, $8^{\mathrm{a}}$ Turma, Data de Publicação: DEJT 15/08/2014.

567 BRASIL. Tribunal Superior do Trabalho. RR - 3671200-96.2008.5.09.0652, Relator Ministro: Cláudio Mascarenhas Brandão, Data de Julgamento: 21/05/2014, $7^{\text {a }}$ Turma, Data de Publicação: DEJT 23/05/2014
} 


\section{CONCLUSÃo}

há feridas

que te ferem

pra te ampliar

há feridas

que são só

partes suas

a te abandonar

Julianna Motter ${ }^{568}$

A vivência plena da sexualidade e do afeto é uma das necessidades que cada pessoa tenciona satisfazer, no curso de sua existência, em busca da felicidade. E os projetos de vida, nesse específico, são tão variados quanto a própria diversidade humana permite.

Toda pessoa é única pelo conjunto de diferenças que a caracteriza, mas é também igual a todo outro ser humano, em virtude da dignidade que the é inerente. Se algumas se realizam, no campo afetivo-sexual, por meio do vínculo com pessoas do sexo oposto; outras tantas atingem esse sentimento de integridade por meio da união com pessoas do mesmo sexo. Isso não as tornas melhores ou piores, umas em relação às outras. Isso as torna diferentes. E só.

Embora, num plano ideal, a vida em sociedade pudesse se desenvolver de forma harmônica e solidária segundo essas premissas, é notório que as relações de reconhecimento recíproco são atravessadas por preconceitos que fazem dela uma experiência permeada por desrespeitos.

A orientação sexual, esse atributo constitutivo da identidade humana que denota formas particulares de se encontrar a plenitude existencial, quando é confrontada com a negativa de reconhecimento, convola-se em estigma e, bem assim, fonte de vergonha, humilhação e despersonalização.

${ }^{568}$ MOTTER, Julianna. De carne e concreto. São Paulo: Patuá, 2014, p. 77. 
A discriminação por orientação sexual é, portanto, uma ferida que, se não tratada e combatida, desarticula identidades, submetendo o eu ao olhar inferiorizante de outro.

É essa a experiência que, ao longo da história, marcou e marca a existência de muitos homossexuais. Uma experiência que se reproduz em todos as esferas da vida social, da família ao trabalho.

No contexto do trabalho, em particular, o reconhecimento do trabalhador homossexual como parceiro no empreendimento coletivo, apto a contribuir com o engajamento de sua subjetividade, é um componente decisivo para que ele se torne uma fonte de prazer, de gratificação, e, no mesmo passo, ferramenta de integração social e de sedimentação da personalidade ${ }^{569}$. O trabalho confere sentido positivo à vida dos trabalhadores homossexuais apenas quando eles são reconhecidos como iguais em sua integralidade, inclusive no que toca à sua orientação sexual.

Sem embargo, não se pode olvidar que, sob à ótica dos modelos produtivos oriundos do neoliberalismo, notadamente o toyotismo, o trabalho, de uma forma geral, se encontra sob pressões que arriscam desconfigurá-lo enquanto espaço de promoção da dignidade humana e da construção da identidade.

$\mathrm{Na}$ era do capitalismo volátil e das empresas maleáveis, a tendência de enxugamento de custos e diminuição das estruturas, em busca de maior eficiência e competividade, tem estendido ao trabalho uma lógica de mercado que identifica o sujeito trabalhador como mero instrumento do processo produtivo.

Ao invés de figurar como referencial de estabilidade e temporalidade, 0 trabalho flexível e desregulamentado, propugnado por esses modelos, é fonte de insegurança, angústia e sofrimento. Competitividade e individualidade são estimuladas pelas empresas, mediante processos de identificação dos obreiros com os valores da própria organização empresarial. A identidade coletiva obreira e os laços de solidariedade que a mantém são, por conseguinte, esgarçados. Nesse passo, as injustiças cotidianas passam a ser justificadas como consequências inevitáveis da guerra econômica.

Mas se o sofrimento é acentuado, na perspectiva neoliberal do trabalho, para todo trabalhador, a presente pesquisa apurou que ele é maior ainda para os

${ }^{569}$ Consultar: DEJOURS, Cristophe. Subjetividade, trabalho e ação. Revista produção, v.14, n. 3, p. 27-34, set./dez. 2004. 
homossexuais, que contam com um grau a mais de precariedade em função do estigma culturalmente associado à sua identidade sexual.

Não há como negar, por um lado, que a organização do trabalho capitalista, desde sua origem, mas também nos modelos hodiernos, é pautada por relações de gênero que erigem uma imagem de trabalhador ideal masculina, que é dominante, racional e competitiva. A mulher e seu equivalente simbólico nesse sistema, o homem homossexual, supostamente não se encaixam nesse papel e, por isso mesmo, encontram resistência no acesso e na manutenção no emprego, além de se submeterem a condições flagrantemente desiguais e degradantes de prestação de serviço.

De outro lado, a resistência obreira aos atuais modelos de organização do trabalho, por vezes acaba reforçando essa concepção excludente de trabalhador, em termos de gênero e sexualidade. Como frisam Dejours e Molinier ${ }^{570}$, com vistas a reconstruir a coesão grupal, os trabalhadores, não raro, se unem em torno de um sentido coletivo de "identidade viril" que, ao mesmo tempo em que lhes permite negar o sofrimento, ampara-se na rejeição e na inferiorização contínua e pública de tudo aquilo que culturalmente evoca o feminino e o afeminado.

Contra toda tendência à diminuição do valor intrínseco à condição humana, existe, porém, o Direito.

No curso desta pesquisa, viu-se que, sob o paradigma do Estado Democrático de Direito, a realização da justiça significa, antes de mais nada, a tutela e a promoção da dignidade da pessoa humana, em uma concepção aberta e expansionista, que se concretiza por meio da garantia dos direitos fundamentais e do pluralismo. E a dignidade é incompatível com a discriminação, na medida em que pressupõe o reconhecimento do outro, a despeito de suas diferenças.

É esse o eixo axiológico adotado pela Constituição Federal de 1988, que transparece em sua própria estrutura. Se anunciam, já de início, a dignidade e o pluralismo, como princípios fundamentais da República, e o combate à toda forma de discriminação, como um de seus objetivos, passando, na sequência, à disciplina dos direitos e garantias fundamentais, pautados, sobretudo, na igualdade e na liberdade humanas.

\footnotetext{
${ }^{570}$ Consultar: DEJOURS, Cristophe. A banalização da injustiça social. 7. ed. Rio de Janeiro: Editora FGV, 2007; e MOLINIER, Pascale. Virilité défensive, masculinité créatrice. Travail, genre et sociétés, n. 3, p. 25-44, mar. 2000.
} 
Frisou-se, ainda, que o trabalho, enquanto potencial espaço para o desenvolvimento das relações de reconhecimento, torna-se igualmente objeto de tutela constitucional. Nesse rumo, só cabe falar em um direito fundamental ao trabalho quando este serve à proteção e à promoção da dignidade humana. $O$ trabalho constitucionalmente protegido e fomentado é aquele que, prestado em condições seguras, edifica identidades e atua em prol da autorrealização de cada indivíduo. Daí porque o ordenamento jurídico brasileiro institui direitos trabalhistas de indisponibilidade absoluta, que asseguram as condições básicas para que o trabalho seja prestado em condições de dignidade.

Do conjunto desses direitos, concluiu-se que o trabalho digno não se coaduna com práticas discriminatórias e excludentes, capazes de acentuar o sofrimento que Ihe é ínsito e obstar seja ele convertido em fonte de prazer, locus de estruturação da identidade e de fortalecimento dos vínculos de solidariedade humana.

A homofobia e o heterossexismo no contexto das relações de emprego são, por conseguinte, antíteses da concepção de trabalho digno assentada pela Constituição Federal de 1988, bem como da noção de trabalho decente estruturada pelo conjunto de diplomas internacionais de direitos humanos ratificados pelo Brasil, em especial, as Convenções da Organização Internacional do Trabalho.

Por isso mesmo, construiu-se uma rede normativa de proteção ao trabalhador discriminado, inclusive por orientação sexual, que prevê, entre outras garantias, o direito à indenização por danos materiais e morais, individuais e coletivos, em caso de discriminação homofóbica ocorrida em qualquer fase da relação empregatícia, inclusive mediante ação civil pública; e o direito à reintegração ou à reparação equivalente, em caso de dispensa discriminatória.

Nessa esteira, a pesquisa também observou que a tutela antidiscrimonatória se estende ao Processo do Trabalho, evitando que desigualdades de poder no plano fático sejam reproduzidas no âmbito processual. É o que permite, por exemplo, a distribuição dinâmica do ônus da prova, em casos de discriminação empregatícia por orientação sexual, quando se verificar excessiva dificuldade do trabalhador para produzir a prova dos fatos alegados ou uma maior facilidade do empregador de comprovar fatos contrários às alegações do reclamante.

Esse instrumental protetivo, todavia, só se torna eficaz em virtude da existência de instituições que o apliquem aos casos concretos, densificando, por meio do discurso constitucional trabalhista, o escopo protetivo do Direito do Trabalho. 
$\mathrm{Na}$ arquitetura constitucional brasileira, a pesquisa apurou que o Tribunal Superior do Trabalho, enquanto órgão de cúpula dotado de competência para uniformizar a interpretação constitucional no âmbito da jurisdição trabalhista, é um dos atores centrais na concretização do direito fundamental ao trabalho digno, por meio do enfrentamento à discriminação empregatícia por orientação sexual. Isso porque, independentemente da proibição expressa ou não, pelo ordenamento jurídico, desse tipo específico de discriminação, o Tribunal Superior do Trabalho tem sido enfático em reputá-la contrária ao princípios e valores que embasam a Constituição Federal de 1988. Nesse sentido, vem construindo um discurso constitucional inclusivo em relação à homossexualidade.

Isso não significa, porém, que a Corte Trabalhista não tenha aspectos a aprimorar com relação a esses casos. Um desses pontos, como se verificou, é o estabelecimento de critérios objetivos para o arbitramento das indenizações por danos morais.

Diante desse quadro, conclui-se, que o Direito do Trabalho, mesmo sob o paradigma do Estado Democrático de Direito, não é capaz de por si só eliminar uma cultura de discriminação a que estão expostos os trabalhadores homossexuais.

Não obstante, ao fornecer mecanismos de reparação e instituir sanções a essas práticas, ele se torna um eficiente instrumento para ressignificar as feridas oriundas do preconceito homofóbico: ao invés do esfacelamento de sua identidade, o obreiro homossexual discriminado que encontra amparo no Direito do Trabalho tem ampliado o seu reconhecimento na comunidade política da qual faz parte e pode reafirmar o seu valor integral enquanto ser humano. 


\title{
REFERÊNCIAS
}

ADORNO, Theodor W., et al. The authoritarian personality. New York: Harper, 1950.

ALEXY, Robert. Teoria de los Derechos Fundamentales. Madri: Centro de Estúdios Políticos y Constitucionales, 2001.

ALVES, Giovanni. Trabalho e subjetividade: o espírito do toyotismo na era do capitalismo manipulatório. São Paulo: Bomtempo, 2011.

ANTUNES, Ricardo. Os sentidos do trabalho: ensaios sobre a afirmação e a negação do trabalho. São Paulo: Bomtempo, 2003.

BARROS, Alice Monteiro de. Curso de direito do trabalho. 7. ed. São Paulo: LTr, 2011.

BARROSO, Luís Roberto. Curso de direito constitucional contemporâneo: os conceitos fundamentais e a construção do novo modelo. São Paulo: Saraiva, 2009.

- Diferentes, mas iguais: $O$ reconhecimento jurídico das relações homoafetivas no Brasil. In: SARMENTO, Daniel; IKAWA, Daniela; PIOVESAN, Flávia (Coord.). Igualdade, diferença e direitos humanos. Rio de Janeiro: Editora Lumen Juris, 2010.

\begin{abstract}
Neoconstitucionalismo e constitucionalização do direito: o triunfo tardio do direito constitucional no Brasil. Disponível em: $<$ http://www.luisrobertobarroso.com.br/wp-

content/themes/LRB/pdf/neoconstitucionalismo_e_constitucionalizacao_do_direito_p t.pdf>. Acesso em 06/04/2016.
\end{abstract}

BAUMAN, Zygmunt. Amor líquido: sobre a fragilidade dos laços humanos. Rio de Janeiro: Zahar, 2004.

Modernidade líquida. Rio de Janeiro: Zahar, 2001.

BELL, Myrtle P. et al. Voice, silence, and diversity in 21st century organizations: strategies for inclusion of, gay, lesbian, bisexual, and transgender employees. Human resource management, v. 50, n. 1, p. 131-146, jan./fev. 2011.

BELMONTE, Alexandre Agra. Responsabilidade por danos morais no Direito do Trabalho. Revista do Tribunal Superior do Trabalho, v. 73, n. 2, p. 25-45, abr./jun. 2007.

BERNARDO, Marcia Espanhol. Trabalho duro, discurso flexível: uma análise das contradições do toyotismo a partir da vivência dos trabalhadores. São Paulo: Editora Expressão, 2009.

BEZERRA, Ricardo dos Santos. Discriminação por orientação sexual na perspectiva dos direitos humanos: um panorama da legislação e ações afirmativas no Brasil. Tese (Doutorado em Direito). Faculdade de Direito da Universidade de Salamanca (USAL), Salamanca, 2011, p. 68-69. 
BÍBLIA. Espanhol. El libro del pueblo de Dios: La Biblia. Disponível em: <http://www.vatican.va/archive/ESL0506/_INDEX.HTM>. Acesso em 06/04/2016.

BÍBLIA. Português. Nova Versão Internacional. Disponível em: <http://www.biblica.com/es-us/la-biblia/>. Acesso em 06/04/2016.

BILGE, S. Théorisations féministes de l'intersectionnalité. Diogène, n. 225, p. 70-88, 18 jan. 2010.

BORGES, Lara Parreira de Faria. Espiando por trás da persiana: um olhar sobre a discriminação traduzida em assédio moral contra a mulher. São Paulo: LTr, 2015.

BORRILLO, Daniel. Homofobia: história e crítica de um preconceito. Belo Horizonte: Autêntica Editora, 2010.

BOURDIEU, Pierre. Contre-feux: propos pour servir à la résistance contre l'invasion néo-libérale. Paris: Raison D’Agir, 1998.

. La dominación masculina. Barcelona: Editorial Anagrama, 2000.

BRASIL. Secretaria de Direitos Humanos. Relatório sobre violência homofóbica no Brasil: ano de 2012. 2013. Disponível em: <http://www.sdh.gov.br/assuntos/lgbt/pdf/relatorio-violencia-homofobica-ano-2012>. Acesso em 10/02/2016.

BRITO FILHO, José Cláudio Monteiro de Brito Filho. Trabalho decente: análise jurídica da exploração do trabalho - trabalho escravo e outras formas de trabalho indigno. 3. ed. São Paulo: LTr, 2013.

BROWNE, John. The glass closet: why coming out is good business. WH Allen, 2014 .

BUTLER, Judith. Frames of war: when is life grievable? London: Verso, 2009.

2006.

Vida precaria: el poder del duelo y la violencia. Buenos Aires: Paidós,

CANOTILHO, J. J. Gomes. Direito constitucional e teoria da constituição. 7. ed. Coimbra: Almedina, 2003.

CARVALHO NETTO, Menelick de; SCOTTI, Guilherme. Os direitos fundamentais e a (in)certerteza do Direito: a produtividade das tensões principiológicas e a superação do sistema de regras. Belo Horizonte: Fórum, 2011.

A Hermenêutica Constitucional e os desafios postos aos Direitos Constitucionais. In: José Adécio Leite Sampaio. (Org.). Jurisdição Constitucional e Direitos Fundamentais. Belo Horizonte: Del Rey, 2003.

CAVAFY, C. P. Collected Poems. Tradução por Edmund Keeley and Philip Sherrard. Princeton University Press, 1992.

CECCARELLI, Paulo Roberto; FRANCO, Samuel. Homossexualidade: verdades e mitos. Bagoas: Revista de Estudos Gays, v. 5, 2010. 
2008.

A invenção da homossexualidade. Bagoas: Revista de Estudos Gays, v. 2,

COLLINS, Barry E. Social Psychology: Social Influence, Attitude Change, Small Groups, and Prejudice, Reading, Mass.: Addison-Wesley, 1970.

COSTA, Ana Maria Machado da. A discriminação por orientação sexual no trabalho - aspectos legais. In: POCAHY, Fernando. (Org.). Rompendo o silêncio: homofobia e heterossexismo na sociedade. Porto Alegre: Nuances, 2007.

COSTA, Lenise Saraiva de Vasconcelos; SILVA, Jorge Ferreira da. As tipologias estratégicas "realmente" existem? Anais do XXVI Encontro Anual da Associação Nacional de Pós-Graduação e Pesquisa em Administração - EnANPAD. Salvador, 2002.

COUTINHO, Maria Luiza Pinheiro. Discriminação no Trabalho: Mecanismos de Combate à Discriminação e Promoção de Igualdade de Oportunidades. Disponível em:

$<$ http://www.oitbrasil.org.br/sites/default/files/topic/discrimination/pub/oit_igualdade_r acial_05_234.pdf>. Acesso em 29 de março de 2016.

CROTEAU, James M. Research on the work experiences of lesbian, gay, and bisexual people: an integrative review of methodology and findings. Journal of vocational behavior, n. 48, p. 195-209, 1996.

CRUZ, Álvaro Ricardo de Souza. O direito à diferença: as ações afirmativas como mecanismo de inclusão social de mulheres, negros, homossexuais e pessoas portadoras de deficiência. $2^{a}$ edição. Belo Horizonte: Del Rey, 2005.

DEJOURS, Cristophe. A banalização da injustiça social. 7. ed. Rio de Janeiro: Editora FGV, 2007.

Subjetividade, trabalho e ação. Revista produção, v.14, n. 3, p. 27-34, set./dez. 2004.

DELGADO, Gabriela Neves; BORGES, Lara Parreira de Faria. A revisitação do princípio da proteção pelo discurso constitucional trabalhista no Tribunal Superior do Trabalho. In: DELGADO, Gabriela Neves; et. al (coord.). Direito constitucional do trabalho: princípios e jurisdição constitucional do TST. São Paulo: LTr, 2015.

DELGADO, Gabriela Neves. Direito fundamental ao trabalho digno. 2. ed. São Paulo: LTr, 2015.

. O trabalho enquanto suporte de valor. Revista da Faculdade de Direito da UFMG. Belo Horizonte, n. 49, p. 63-80, jul./dez. 2006.

DELGADO, Maurício Godinho; DELGADO, Gabriela Neves. 70 anos da Justiça do Trabalho. Revista do Tribunal Superior do Trabalho, Brasília, vol. 77, n. 2, abr./jun. 2011.

Constituição da República e direitos fundamentais. 3. ed. São Paulo: LTr, 
. Tratado jurisprudencial de direito constitucional do trabalho. São Paulo: Editora Revista dos Tribunais, 2013.

DELGADO, Maurício Godinho. Curso de direito do trabalho. 11. ed. São Paulo: LTr, 2012.

Curso de direito do trabalho. 13. ed. São Paulo: LTr, 2014

. Proteções contra discriminação na relação de emprego. In: RENAULT, Luiz Otávio Linhares; VIANA, Márcio Túlio; CANTELLI, Paula Oliveira (coord.). Discriminação. 2. ed. São Paulo: LTr, 2010.

DIAS, Maria Berenice de. Manual de Direito das Famílias. 6. ed., rev., atual. e ampl. São Paulo: Editora Revista dos Tribunais, 2010.

DRYDAKIS, Nick. Sexual orientation discrimination in the labour market. Labour economics, v. 16, p. 364-372, 2009.

DWORKIN, Ronald. Levando os direitos a sério. 2. ed. São Paulo: Martins Fontes, 2007.

O império do direito. 2. ed. São Paulo: Martins Fontes, 2007.

ECCEL, Cláudia Sirangelo; ALCADIPANI, Rafael. (Re)descobrindo as masculinidades. In: FREITAS, Maria Ester; DANTAS, Marcelo (orgs.). Diversidade sexual e trabalho. São Paulo: Cengage Learning, 2012.

ELIAS, Norbert; SCOTSON, John L. Os estabelecidos e os outsiders: sociologia das relações de poder a partir de uma pequena comunidade. Rio de Janeiro: Jorge Zahar Editor, 2000.

ENRIQUEZ, Eugène. Perda do trabalho, perda da identidade. Cad. Esc. Leg., Belo Horizonte, 5(9), jul./dez. 1999.

FACHIN, Luiz Edson. Direito de família: elementos críticos à luz do novo código civil brasileiro. 2. ed. Rio de Janeiro: Renovar, 2003.

FERRAJOLI, Luigi. Igualdad y diferencia. Igualdad y no discriminación: el reto de la diversidad. Quito: Danilo Caicedo Tapia e Angélica Porras Velasco (editores), 2010.

FONE, Byrne. Homophobia: a history. Nova York: Picador, 2000.

FOUCAULT, Michel. História da sexualidade I: a vontade de saber. Rio de Janeiro: Edições Graal, 1988.

FRASER, Nancy. Heterosexism, Misrecognition, and Capitalism: A Response to Judith Butler. Social Text, n. 52/53, 1997.

Reconhecimento sem ética?. Lua Nova, São Paulo, n. 70, p. 101-138, 2007.

Scales of justice: reimagining political space in a globalizing world. New York: Columbia University Press, 2008. 
FREUD, Sigmund. Observações psicanalíticas sobre um caso de paranoia relatado em autobiografia: (“O caso Schreber"): artigos sobre técnica e outros textos (1911-1913). São Paulo: Cia. das Letras, 2010.

. Trois essais sur la théorie de la sexualité. Paris: Gallimard, 1987.

GARCIA, Agnaldo; SOUZA, Eloisio Moulin de. Sexualidade e trabalho: estudo sobre a discriminação de homossexuais masculinos no setor bancário. Revista de Administração Pública - RAP, v. 44, n. 6, p. 1353-77, nov./dez. 2010.

GAULEJAC, Vincent de. As origens da vergonha. São Paulo: Via Lettera Editora e Livraria, 2006.

. Identité. In: Barus-Michel, J.; Enriquez, E.; Lévy, A (coord.). Vocabulaire de psychosociologie: références et positions. Paris: Érès, 2002.

GGB. Assassinato de homossexuais (LGBT) no Brasil: relatório 2014. Disponível em: <https://homofobiamata.files.wordpress.com/2015/01/relatc3b3rio-2014s.pdf>. Acesso em 10/02/2016.

GINI, Al. Work, identity and self: how we are formed by the work we do. Journal of the business ethics, v. 17, p. 707-714, 1998.

GOFFMAN, Erving. Estigma: notas sobre a manipulação da identidade deteriorada. 4. Ed. Rio de Janeiro: LTC, 1988.

. Manicômios, prisões e conventos. São Paulo: Perspectiva, 1987.

GOMES, Ana Virgínia Moreira; FREITAS JÚNIOR, Antônio Rodrigues de. (Org.). A Declaração de 1998 da OIT sobre princípios e direitos fundamentais no trabalho: análise do seu significado e efeitos. São Paulo: LTr, 2014.

GONÇALVES, Carlos Roberto. Direito civil brasileiro, vol. 4: responsabilidade civil. 5. ed. São Paulo: Saraiva: 2010.

GREEN, James N. Mais amor e mais tesão: a construção de um movimento brasileiro de gays, lésbicas e travestis. Cadernos Pagu, n. 15, 2000.

GUEDES, Márcia Novaes. Terror psicológico no trabalho. 3. ed. São Paulo: LTr, 2008.

HARVEY, David. A condição pós-moderna. São Paulo: Loyola, 1989.

HELOANI, José Roberto; CAPITÃO, Cláudio Garcia. Sexualidade e trabalho na visão da psicanálise. In: FREITAS, Maria Ester; DANTAS, Marcelo (orgs.). Diversidade sexual e trabalho. São Paulo: Cengage Learning, 2012.

Assédio moral - um ensaio sobre a exploração da dignidade no trabalho. RAE-eletrônica, v. 3, n. 1, jan./jun. 2004. Disponível em: <http://www.scielo.br/pdf/raeel/v3n1/v3n1a12>. Acesso em 8 de março de 2016. 
HEWLETT, Sylvia Ann et al. The power of "out" 2.0: LGBT in the workplace. Nova York: Center for Talent Innovation, 2013.

HIRATA, Helena. Gênero, classe e raça Interseccionalidade e consubstancialidade das relações sociais. Tempo social, v. 26 , n. 1, p. 61-73, 2014

HIRATA, Helena; KERGOAT, Danièle. Novas configurações da divisão sexual do trabalho. Cadernos de Pesquisa, v. 37, n. 132, p. 595-609, set./dez. 2007.

HIRIGOYEN, Marie-France. El acoso moral: el maltrato psicológico en la vida cotidiana. Barcelona: Paidós, 1999.

HIRSCHMAN, Albert O. Exit, voice, and loyalty: responses to decline in firms, organizations, and States. Cambridge: Harvard University Press, 1970.

HONNETH, Axel. Luta por reconhecimento: a gramática moral dos conflitos sociais. São Paulo: Ed. 34, 2003.

HOUAISS, Antônio. Grande Dicionário Houaiss da Língua Portuguesa. Disponível em: <http://houaiss.uol.com.br/>. Acesso em 06/04/2016.

HUNT, Lynn. A invenção dos direitos humanos: uma história. São Paulo: Companhia das Letras, 2009, p. 202-203.

IBOPE Inteligência. União estável entre homossexuais. Disponível em: <http://www4.ibope.com.br/download/casamentogay.pdf>. Acesso em 10/02/2016.

ILGA. State-sponsored homophobia. Word survey of laws: criminalization, protection and recognition of same-sex love. VALENZA, Alessia; CAROLL, Aengus (Coord.). 10. ed., mai/2015.

IRIGARAY, Hélio Arthur Reis; FREITAS, Maria Ester de. Sexualidade e organizações: estudo sobre lésbicas no ambiente de trabalho. Organ. Soc., Salvador, v. 18, n. 59, p. 625-641, dez. 2011.

IRIGARAY, Hélio Arthur Reis; SARAIVA, Luiz Alex Silva; CARRIERI, Alexandre de Pádua. Humor e discriminação por orientação sexual no ambiente organizacional. Revista de administração contemporânea, v.14, n.5, p. 890-906, Set./Out. 2010.

IRIGARAY, Hélio Arthur Reis. Estratégias de sobrevivência dos gays no ambiente de trabalho. Anais do XXXI Encontro Anual da Associação Nacional de PósGraduação e Pesquisa em Administração - EnANPAD, Rio de Janeiro, 2007, 31.

JORBER, Judith. Beyond the binaries: depolarizing the categories of sex, sexuality, and gender. Sociological Inquiry, v. 66, n. 2, p. 143-160, Abr. 1996.

KANT, Immanuel. Fundamentação da metafísica dos costumes. Trad. Paulo Quintela. Lisboa: Edições 70, 2007.

KAUFMAN, Joanne K.; JOHNSON, Cathryn. Stigmatized individuals and the process of identity. The Sociological Quarterly, v. 45, n. 4, p. 807-833, 2004. 
KERGOAT, Danièle. Dinâmica e consubstancialidade das relações sociais. Novos Estudos-CEBRAP, n. 86, p. 93-103, 2010.

LE PLACARD. Direção: Francis Veber. Produção: Patrice Ledoux. Intérpretes: Daniel Auteuil; Gérard Depardieu; Thierry Lhermitte. Roteiro: Francis Veber. França: Miramax Films, 2001 (84min).

LEE BADGETT, M. V. Discrimination based on sexual orientation: a review of the literature in economics and beyond. In: LEE BADGETT, M. V.; FRANK, Jefferson. Sexual orientation discrimination: an international perspective. New York: Routledge, 2007

. The economic cost of stigma and the exclusion of LGBT people: a case study of India. Washington, DC: World Bank, 2014, p. 25. Disponível em: <https://openknowledge.worldbank.org/handle/10986/21515>. Acesso em 01/03/2016.

LIMA, Suzana Borges Viegas de. O estatuto jurídico das relações homoafetivas. Brasília: Gazeta Jurídica, 2015.

LOURENÇO FILHO, Ricardo; PAIXÃO, Cristiano. Impactos da terceirização no mundo do trabalho: tempo, espaço e subjetividade. Revista do Tribunal Superior do Trabalho, Brasília, v. 80, n. 3, jul./set. 2014.

LUÑO, Antonio Enrique Pérez. La universalidade de los derechos humanos y el Estado constitucional. 1. ed. Bogotá: Universidad Externado de Colombia, 2002.

MALLET, Estevão. Discriminação e processo do trabalho. In: RENAULT, Luiz Otávio Linhares; VIANA, Márcio Túlio; CANTELLI, Paula Oliveira (coord.). Discriminação. 2. ed. São Paulo: LTr, 2010.

Igualdade, discriminação e direito do trabalho. Revista do Tribunal Superior do Trabalho, v. 76, n. 3, p. 17-51, jul./set. 2010.

MCGINLEY, Ann C. Erasing boundaries: masculinities, sexual minorities, and employment discrimination. University of Michigan Journal of Law Reform, v. 43:3.

. Creating masculine identities: bullying and harassment "because of sex". University of Colorado Law Review, v. 79, 2008.

MELLO, Celso Antônio Bandeira de. O conteúdo jurídico do princípio da igualdade. 3. Ed. São Paulo: Malheiros Editores, 2009.

MEYER, Ilan H. Minority Stress and Mental Health in Gay Men. Journal of Health and Social Behavior, Vol. 36, No. 1, Mar. 1995.

MOLINIER, Pascale. Virilité défensive, masculinité créatrice. Travail, genre et sociétés, n. 3, p. 25-44, mar. 2000.

MOREIRA, Adailson. A homossexualidade no Brasil no século XIX. Bagoas: Revista de Estudos Gays, v. 7, 2012. 
MOTT, Luiz. Relações raciais entre homossexuais no Brasil colônia. Revista brasileira de história, São Paulo, v.5, n.10, p. 99-122, mar./ago. 1985.

NARDI, Henrique Caetano. Nas tramas do humano: quando a sexualidade interdita o trabalho. In: POCAHY, Fernando (org.). Rompendo o silêncio: homofobia e heterossexismo na sociedade contemporânea. Porto Alegre: Nuances, 2007.

NEVES, Marcelo. A constitucionalização simbólica. 3. ed. São Paulo: WMF Martins Fontes, 2011.

. Entre hidra e Hércules: princípios e regras constitucionais como diferença paradoxal do sistema jurídico. São Paulo: WMF Martins Fontes, 2013

NICOLI, Pedro Augusto Gravatá. A condição jurídica do trabalhador imigrante no direito brasileiro. São Paulo: LTr, 2011.

OIT; UNAIDS; PNUD. Promoção dos Direitos Humanos de pessoas LGBT no Mundo do Trabalho. 2. ed. revista e ampliada. OIT, 2015.

OIT. Declaração da OIT sobre os princípios e direitos fundamentais no trabalho e seu seguimento. Disponível em:<http://www.ilo.org/wcmsp5/groups/public/--americas/---ro-lima/---ilo-brasilia/documents/publication/wcms_230648.pdf $>$. Acesso em 4 de abril de 2016.

. Igualdade no trabalho: um desafio contínuo. Relatório Global no quadro do seguimento da Declaração sobre os Princípios e Direitos Fundamentais no Trabalho. Genebra: OIT, 2011.

. Igualdade no trabalho: enfrentando desafios. Relatório Global no quadro do seguimento da Declaração sobre os Princípios e Direitos Fundamentais no Trabalho. Genebra: OIT, 2007.

La igualdad en el trabajo: afrontar los retos que se plantean. Informe global con arreglo al seguimiento de la Declaración de la OIT relativa a los principios y derechos fundamentales en el trabajo. Genebra: OIT, 2007.

ORGULLO (PRIDE) en el trabajo: un estudio sobre la discriminación en el trabajo por motivos de orientación sexual e identidad de género en Argentina. Genebra: OIT, 2015.

R200 — Recomendação sobre o HIV e a AIDS e o Mundo do Trabalho, 2010.

OLIVEIRA, Pedro Paulo de. A construção social da masculinidade. Belo Horizonte: Editora UFMG, 2004.

ONU. E/C.12/GC/18 (O direito ao trabalho - Comentário Geral n 18), 2006.

E/C.12/GC/20 (Não discriminação em direitos econômicos, sociais e culturais - Comentário Geral n²0), 2009.

CCPR/C/50/D/488/1992 (Toonen v. Australia), 1994. 
PASTORE, Fortunato. O Batalhão Sagrado de Tebas: militarismo e homoafetividade na Grécia Antiga. Revista Trilhas da História. Três Lagoas, v. 1, n. 1., jun./nov. 2011.

PEDUZZI, Maria Cristina Irigoyen. Assédio moral. Revista do Tribunal Superior do Trabalho, v. 73, n. 2, p. 25-45, abr./jun. 2007, p. 39.

PEREIRA, Tânia da Silva. Direito da Criança e do Adolescente: uma proposta interdisciplinar. 1. ed. Rio de Janeiro: Renovar / UNICEF, 1996;

. O melhor interesse da criança: um debate interdisciplinar. Rio de Janeiro: Renovar, 2000.

PIOVESAN, Flávia. Igualdade, diferença e direitos humanos: perspectivas global e regional. In: SARMENTO, Daniel; IKAWA, Daniela; PIOVESAN, Flávia (Coord.). Igualdade, diferença e direitos humanos. Rio de Janeiro: Editora Lumen Juris, 2010.

PLATÃO. O banquete. Tradução, apresentação e notas Edson Bini. São Paulo: EDIPRO, 2012.

PORCHMANN, Marcio. O trabalho sob fogo cruzado: exclusão, desemprego e precarização no final do século. São Paulo: Contexto, 1999.

Princípios de Yogyakarta: Princípios sobre a aplicação da legislação internacional de direitos humanos em relação à orientação sexual e identidade de gênero. Disponível em: <http://www.yogyakartaprinciples.org/principles_en.pdf>. Acesso em 05/04/2016

PRIORE, Mary Del. História do amor no Brasil. São Paulo: Contexto, 2005.

REALE, Miguel. Lições preliminares de direito. 27. ed. São Paulo: Saraiva, 2002.

Teoria Tridimensional do Direito. 5. ed. São Paulo: Saraiva, 2002.

RIOS, Roger Raupp; SOUZA, Luiz Gustavo Oliveira de; SPONCHIADO, Tobias. Notícias de homofobia e proteção jurídica antidiscriminatória. In: DINIZ, Debora; OLIVEIRA, Rosana Medeiros de. (Orgs.). Notícias de homofobia no Brasil. Brasília: Letras Livres, 2014.

RIOS, Roger Raupp. Direito da Antidiscriminação, sexo, sexualidade e gênero: a compreensão da proibição constitucional de discriminação por motivo de sexo. In: SARMENTO, Daniel; IKAWA, Daniela; PIOVESAN, Flávia (Coord.). Igualdade, diferença e direitos humanos. Rio de Janeiro: Editora Lumen Juris, 2010.

O conceito de homofobia na perspectiva dos direitos humanos e no contexto dos estudos sobre preconceito e discriminação. In: POCAHY, Fernando. (Org.). Rompendo o silêncio: homofobia e heterossexismo na sociedade. Porto Alegre: Nuances, 2007.

. O direito da antidiscriminação e a tensão entre o direito à diferença e o direito geral de igualdade. Direitos Fundamentais e Justiça, n. 18, p. 169-179, 2012. 
O princípio da igualdade e a discriminação por orientação sexual: a homossexualidade no Direito brasileiro e norte-americano. São Paulo: Editora Revista dos Tribunais, 2002.

ROSENFELD, Michel. A identidade do sujeito constitucional. Tradução de Menelick de Carvalho Netto. Belo Horizonte: Mandamentos: 2003.

SALGADO, Joaquim Carlos. Estado ético e estado poiético. Revista do Tribunal de Contas do Estado de Minas Gerais, Belo Horizonte, v. 27, n. 2, abre./jun., 1998. Disponível em: $\quad$ http://200.198.41.151:8081/tribunal_contas/1998/02/sumario?next=3>. Acesso em: 11/02/2016.

SANTOS, Boaventura de Souza. As tensões da modernidade. Texto apresentado no Fórum Social Mundial, Porto Alegre, 2001. Disponível em: <http://www.susepe.rs.gov.br/upload/1325792284_As\%20tens\%C3\%B5es\%20da\%2 0Modernidade\%20-\%20Boaventura\%20de\%20Sousa\%20Santos.pdf>. Acesso em: 06/04/2016.

SANTOS, Dartagnan Ferrer dos Santos. Igualdade, diferença e identidade: três pilares da alteridade nas relações de trabalho de um mundo pluralista. In: BARZOTTO, Luciane Cardoso (Coord.). Trabalho e igualdade: tipos de discriminação no ambiente de trabalho. Porto Alegre: Livraria do Advogado Editora, 2012.

SARLET, Ingo Wolfgang. A eficácia dos direitos fundamentais: uma teoria geral dos direitos fundamentais na perspectiva constitucional. 10. ed. Porto Alegre: Livraria do Advogado Editora, 2011.

Dignidade da pessoa humana e direitos fundamentais na Constituição Federal de 1988. 9. ed. Porto Alegre: Livraria do Advogado Editora, 2011.

. Notas sobre a dignidade da pessoa humana na jurisprudência do Supremo Tribunal Federal. In: SARMENTO, Daniel; SARLET, Ingo Wolfgang (Coord.). Direitos fundamentais no Supremo Tribunal Federal: balanço e crítica. Rio de Janeiro: Lumen luris, 2011.

SCHULMAN, Sarah. Homofobia familiar: uma experiência em busca de reconhecimento. Trad. Felipe Bruno Martins Fernandes. Bagoas: Revista de Estudos Gays, v. 5, p. 67-78, 2010.

SEDGWICK, Eve Kosofsky. A epistemologia do armário. Cadernos Pagu, n. 28, p. 19-54, jan./jun. 2007.

SILVA, Christine Oliveira Peter da. Transjusfundamentalidade: diálogos judiciais transnacionais sobre direitos fundamentais. Tese (Doutorado em Direito). Faculdade de Direito da Universidade de Brasília (UnB), Brasília, 2013.

SIQUEIRA, Marcus Vinícius et al. Homofobia e violência moral no trabalho no Distrito Federal. Revista Organizações \& Sociedade, v. 16, n. 50, p. 447-461, jul./set. 2009.

SIQUEIRA, Marcus Vinícius; ANDRADE, Augusto. Em busca de uma pedagogia gay no ambiente de trabalho. In: FREITAS, Maria Ester; DANTAS, Marcelo (orgs.). Diversidade sexual e trabalho. São Paulo: Cengage Learning, 2012. 
SOUTO MAIOR, Jorge Luiz. A fúria. Revista do Tribunal Superior do Trabalho, Brasília, v. 68, n. 3, jul./dez. de 2002.

. O direito do trabalho e as diversas formas de discriminação. Revista do Tribunal Superior do Trabalho, Brasília, vol. 68, n² 2, abr./jun. 2002.

SOUZA JÚNIOR, Armando Araújo de; et al. Aspectos da dominação masculina no assédio moral ao profissional homossexual no polo industrial de Manaus. Revista Pensamento \& Realidade, v. 28, n. 1, p. 83-102, 2013.

SOUZA, Eloisio Moulin de; PEREIRA, Severino Joaquim Nunes. (Re)produção do heterossexismo e da heteronormatividade nas relações de trabalho: a discriminação de homossexuais por homossexuais. Revista de Administração Mackenzie - RAM, v. 14, n. 4, p. 76-105, jul./ago. 2013.

STETS, Jan E.; BURKE, Peter J. Identity theory and social identity theory. Social psychology quarter, v. 2000, n. 3, p. 224-237, 2000.

SUPIOT, Alain. O espírito de Filadélfia: a justiça social diante do mercado total. Porto Alegre: Sulina, 2014.

TERTO JR., Veriano. Homossexualidade e saúde: desafios para a terceira década de epidemia de HIVIAIDS. Horizontes antropológicos, Porto Alegre, v. 8, n. 17, p. 147158, Jun. 2002.

THE NORMAL HEART. Direção: Ryan Murphy. Produção: Scott Ferguson. Intérpretes: Mark Ruffalo; Matt Bomer; Taylor Kitsch; Jim Parsons; Julia Roberts. Roteiro: Larry Kramer. Estados Unidos: HBO, 2014, 132min.

TILCSIK, András. Pride and prejudice: discrimination against openly gay men in the United States. American journal of sociology, v. 117, n. 2, p. 585-626, 2011.

VAINFAS, Ronaldo. Moralidades brasílicas: deleites sexuais e linguagem erótica na sociedade escravista. In: NOVAIS, Fernando A.; MELLO E SOUZA, Laura de. História da vida privada no Brasil: cotidiano e vida privada na América portuguesa. v. 1. São Paulo: Companhia das Letras, 1997.

Trópico dos pecados: moral, sexualidade e inquisição no Brasil. Rio de Janeiro: Nova Fronteira, 1997.

VECCHIATTI, Paulo Roberto lotti. Manual da homoafetividade: da possibilidade jurídica do casamento civil, da união estável e da adoção por casais homoafetivos. São Paulo: Método, 2012.

VIANA, Márcio Túlio; PIMENTA, Raquel Betty de Castro. A proteção trabalhista contra os atos discriminatórios (análise da Lei n. 9.029/95). In: RENAULT, Luiz Otávio Linhares; VIANA, Márcio Túlio; CANTELLI, Paula Oliveira (coord.). Discriminação. 2. ed. São Paulo: LTr, 2010.

VITAL, Christina; LOPES, Paulo Victor Leite. Religião e política: uma análise da atuação de parlamentares evangélicos sobre direitos das mulheres e de LGBTs no Brasil. Rio de Janeiro: Fundação Heinrich Böll, 2012. 
WALDO, Craig R. Working in a minority context: a structural model of heterosexism as minority stress in workplace. Journal of counseling psychology, v. 46, n. 2, p. 218232, 1999.

WELZER-LANG, Daniel. A construção do masculino: dominação das mulheres e homofobia. Revista Estudos Feministas, vol.9, n.2, 2001.

YOUNG-BRUEHL, Elisabeth. The anatomy of prejudice. Cambridge: Harvard University Press, 1996. 
APÊNDICE

Quadro 1. Discriminação por orientação sexual no TST

\begin{tabular}{|c|c|c|c|c|c|c|}
\hline $\begin{array}{l}\text { Número do } \\
\text { processo }\end{array}$ & $\begin{array}{c}\text { Data de } \\
\text { publicação }\end{array}$ & $\begin{array}{l}\text { Gênero do(a) } \\
\text { reclamante }\end{array}$ & $\begin{array}{c}\text { Discriminação } \\
\text { alegada }\end{array}$ & $\begin{array}{l}\text { Tema do } \\
\text { Recurso }\end{array}$ & Dispositivo & $\begin{array}{c}\text { Danos } \\
\text { morais (R\$) }\end{array}$ \\
\hline $\begin{array}{c}\text { AIRR - 161- } \\
02.2012 .5 .01 .0401\end{array}$ & $18 / 03 / 16$ & Feminino & $\begin{array}{c}\text { Assédio moral. } \\
\text { Humor } \\
\text { vexatório. } \\
\text { Ofensas. }\end{array}$ & $\begin{array}{c}\text { Valor da } \\
\text { indenização. }\end{array}$ & Desprovido & 10.000 \\
\hline $\begin{array}{c}\text { ARR - 452300- } \\
12.2009 .5 .09 .0670\end{array}$ & $26 / 02 / 16$ & Masculino & $\begin{array}{c}\text { Humor } \\
\text { vexatório. } \\
\text { Insinuação } \\
\text { sobre } \\
\text { sexualidade. }\end{array}$ & $\begin{array}{l}\text { Configuração } \\
\text { da lesão. } \\
\text { Valor da } \\
\text { indenização }\end{array}$ & $\begin{array}{c}\text { Não } \\
\text { conhecido }\end{array}$ & 10.000 \\
\hline $\begin{array}{c}\text { AIRR - 1360- } \\
65.2013 .5 .12 .0030\end{array}$ & $19 / 02 / 16$ & Feminino & $\begin{array}{c}\text { Assédio moral. } \\
\text { Humilhação. } \\
\text { Ofensas. }\end{array}$ & $\begin{array}{c}\text { Configuração } \\
\text { da lesão. } \\
\text { Valor da } \\
\text { indenização. }\end{array}$ & Desprovido & 20.000 \\
\hline $\begin{array}{c}\text { RR - 257440- } \\
71.2002 .5 .02 .0372\end{array}$ & $12 / 02 / 16$ & Masculino & $\begin{array}{l}\text { Humilhação. } \\
\text { Humor } \\
\text { vexatório. } \\
\text { Insinuação } \\
\text { sobre } \\
\text { sexualidade. } \\
\text { Ofensas. } \\
\text { Preterição de } \\
\text { promoção. } \\
\end{array}$ & $\begin{array}{l}\text { Cerceamento } \\
\text { de defesa. }\end{array}$ & Provido & $\begin{array}{c}\text { Sem } \\
\text { condenação }\end{array}$ \\
\hline $\begin{array}{c}\text { AIRR - 224- } \\
97.2013 .5 .04 .0016\end{array}$ & $04 / 12 / 15$ & Feminino & $\begin{array}{l}\text { Perseguição } \\
\text { por superior. }\end{array}$ & $\begin{array}{l}\text { Configuração } \\
\text { da lesão. }\end{array}$ & Desprovido & $\begin{array}{c}\text { Sem } \\
\text { condenação }\end{array}$ \\
\hline $\begin{array}{c}\text { AIRR - 2045- } \\
14.2012 .5 .22 .0003\end{array}$ & $04 / 12 / 15$ & Feminino & $\begin{array}{l}\text { Assédio moral. } \\
\text { Ofensas. }\end{array}$ & $\begin{array}{c}\text { Configuração } \\
\text { da lesão. }\end{array}$ & Desprovido & $\begin{array}{c}\text { Sem } \\
\text { condenação }\end{array}$ \\
\hline $\begin{array}{c}\text { RR - 129- } \\
73.2012 .5 .10 .0812\end{array}$ & $04 / 12 / 15$ & Masculino & $\begin{array}{c}\text { Assédio moral. } \\
\text { Humilhação. } \\
\text { Ofensas. }\end{array}$ & $\begin{array}{c}\text { Valor da } \\
\text { indenização. }\end{array}$ & Provido & 50.000 \\
\hline $\begin{array}{c}\text { AIRR - 1149- } \\
92.2012 .5 .02 .0078 \\
\end{array}$ & $25 / 09 / 15$ & Masculino & $\begin{array}{c}\text { Assédio moral. } \\
\text { Ofensas. }\end{array}$ & $\begin{array}{c}\text { Configuração } \\
\text { da lesão. }\end{array}$ & Desprovido & 10.000 \\
\hline $\begin{array}{c}\text { AIRR - 3603- } \\
27.2013 .5 .02 .0202\end{array}$ & $18 / 09 / 15$ & Masculino & $\begin{array}{c}\text { Assédio moral. } \\
\text { Humor } \\
\text { vexatório. } \\
\text { Ofensas. } \\
\end{array}$ & $\begin{array}{c}\text { Configuração } \\
\text { da lesão. } \\
\text { Valor da } \\
\text { indenização. }\end{array}$ & Desprovido & 10.000 \\
\hline $\begin{array}{c}\text { AIRR - 56500- } \\
21.2009 .5 .05 .0030\end{array}$ & $18 / 08 / 15$ & Masculino & $\begin{array}{c}\text { Assédio moral. } \\
\text { Humor } \\
\text { vexatório. } \\
\text { Ofensas. } \\
\end{array}$ & $\begin{array}{l}\text { Configuração } \\
\text { da lesão. } \\
\text { Valor da } \\
\text { indenização. }\end{array}$ & Desprovido & $37.705,50$ \\
\hline $\begin{array}{c}\text { RR - 230581- } \\
05.2010 .5 .05 .0000\end{array}$ & $14 / 08 / 15$ & Masculino & $\begin{array}{c}\text { Assédio moral. } \\
\text { Humor } \\
\text { vexatório. } \\
\text { Insinuação } \\
\text { sobre } \\
\text { sexualidade. } \\
\end{array}$ & $\begin{array}{l}\text { Configuração } \\
\text { da lesão. } \\
\text { Valor da } \\
\text { indenização. }\end{array}$ & Provido & 5.000 \\
\hline $\begin{array}{c}\text { AIRR - 1366- } \\
42.2012 .5 .03 .0100\end{array}$ & 07/08/15 & Masculino & $\begin{array}{l}\text { Assédio moral. } \\
\text { Humilhação. } \\
\text { Humor } \\
\text { vexatório. } \\
\text { Insinuação } \\
\text { sobre } \\
\text { sexualidade. } \\
\text { Ofensas. } \\
\end{array}$ & $\begin{array}{l}\text { Configuração } \\
\text { da lesão. } \\
\text { Valor da } \\
\text { indenização. } \\
\text { Danos } \\
\text { materiais. }\end{array}$ & Desprovido & 5.000 \\
\hline $\begin{array}{c}\text { AIRR - 2880- } \\
86.2013 .5 .10 .0104\end{array}$ & $26 / 06 / 15$ & Masculino & $\begin{array}{c}\text { Assédio moral. } \\
\text { Discriminação. } \\
\text { Humilhação. }\end{array}$ & $\begin{array}{l}\text { Configuração } \\
\text { da lesão. }\end{array}$ & Desprovido & 10.000 \\
\hline $\begin{array}{l}\text { Ag-AIRR - 62400- } \\
63.2011 .5 .17 .0132\end{array}$ & $12 / 06 / 15$ & Masculino & $\begin{array}{c}\text { Assédio moral. } \\
\text { Humilhação. } \\
\text { Humor } \\
\text { vexatório. } \\
\text { Insinuação } \\
\text { sobre } \\
\text { sexualidade. } \\
\end{array}$ & $\begin{array}{l}\text { Configuração } \\
\text { da lesão. } \\
\text { Valor da } \\
\text { indenização. }\end{array}$ & Desprovido & 20.000 \\
\hline $\begin{array}{c}\text { AIRR - 61600- } \\
60.2013 .5 .17 .0004\end{array}$ & $24 / 04 / 15$ & Masculino & $\begin{array}{l}\text { Assédio moral. } \\
\text { Ofensas. }\end{array}$ & $\begin{array}{c}\text { Valor da } \\
\text { indenização. }\end{array}$ & Desprovido & 3.000 \\
\hline
\end{tabular}




\begin{tabular}{|c|c|c|c|c|c|c|}
\hline $\begin{array}{l}\text { Número do } \\
\text { processo }\end{array}$ & $\begin{array}{c}\text { Data de } \\
\text { publicação }\end{array}$ & $\begin{array}{c}\text { Gênero do(a) } \\
\text { reclamante }\end{array}$ & $\begin{array}{c}\text { Discriminação } \\
\text { alegada }\end{array}$ & $\begin{array}{l}\text { Tema do } \\
\text { Recurso }\end{array}$ & Dispositivo & $\begin{array}{c}\text { Danos } \\
\text { morais (R\$) }\end{array}$ \\
\hline $\begin{array}{c}\text { RR - 2308- } \\
56.2012 .5 .03 .0009\end{array}$ & $17 / 04 / 15$ & Masculino & $\begin{array}{c}\text { Assédio moral. } \\
\text { Humilhação. } \\
\text { Humor } \\
\text { vexatório. }\end{array}$ & $\begin{array}{c}\text { Configuração } \\
\text { da lesão. } \\
\text { Valor da } \\
\text { indenização. }\end{array}$ & $\begin{array}{c}\text { Não } \\
\text { conhecido }\end{array}$ & $\begin{array}{c}\text { Sem } \\
\text { informações }\end{array}$ \\
\hline $\begin{array}{c}\text { RR - 949- } \\
45.2010 .5 .09 .0245\end{array}$ & $20 / 03 / 15$ & Masculino & $\begin{array}{l}\text { Assédio moral. } \\
\text { Humilhação. } \\
\text { Ofensas. }\end{array}$ & $\begin{array}{l}\text { Configuração } \\
\text { da lesão. } \\
\text { Valor da } \\
\text { indenização. }\end{array}$ & $\begin{array}{c}\text { Não } \\
\text { conhecido }\end{array}$ & 4.000 \\
\hline $\begin{array}{c}\text { RR - 7100- } \\
44.2013 .5 .17 .0004\end{array}$ & $12 / 12 / 14$ & Feminino & $\begin{array}{c}\text { Dispensa } \\
\text { discriminatória. } \\
\text { Perseguição } \\
\text { por superior. }\end{array}$ & $\begin{array}{c}\text { Configuração } \\
\text { da lesão. } \\
\text { Valor da } \\
\text { indenização. }\end{array}$ & $\begin{array}{c}\text { Não } \\
\text { conhecido }\end{array}$ & $\begin{array}{c}\text { Sem } \\
\text { condenação }\end{array}$ \\
\hline $\begin{array}{c}\text { AIRR - 2447- } \\
98.2010 .5 .02 .0043\end{array}$ & $12 / 09 / 14$ & Masculino & Ofensas. & $\begin{array}{c}\text { Configuração } \\
\text { da lesão. } \\
\text { Valor da } \\
\text { indenização. }\end{array}$ & Desprovido & 10.000 \\
\hline $\begin{array}{c}\text { RR - 3290- } \\
61.2011 .5 .12 .0007\end{array}$ & $15 / 08 / 14$ & Masculino & $\begin{array}{l}\text { Assédio moral. } \\
\text { Humilhação. } \\
\text { Humor } \\
\text { vexatório. } \\
\text { Insinuação } \\
\text { sobre } \\
\text { sexualidade. }\end{array}$ & $\begin{array}{l}\text { Configuração } \\
\text { da lesão. }\end{array}$ & Provido & 5.000 \\
\hline $\begin{array}{c}\text { RR - 3671200- } \\
96.2008 .5 .09 .0652\end{array}$ & $23 / 05 / 14$ & Masculino & $\begin{array}{c}\text { Assédio moral. } \\
\text { Humilhação. } \\
\text { Humor } \\
\text { vexatório. } \\
\text { Insinuação } \\
\text { sobre } \\
\text { sexualidade. } \\
\text { Ofensas. } \\
\end{array}$ & $\begin{array}{l}\text { Configuração } \\
\text { da lesão. } \\
\text { Valor da } \\
\text { indenização. }\end{array}$ & $\begin{array}{c}\text { Não } \\
\text { conhecido }\end{array}$ & 10.000 \\
\hline $\begin{array}{c}R R-1458- \\
59.2011 .5 .08 .0118\end{array}$ & $07 / 06 / 13$ & Masculino & $\begin{array}{c}\text { Assédio moral. } \\
\text { Dispensa } \\
\text { discriminatória. } \\
\text { Humor } \\
\text { vexatório. }\end{array}$ & $\begin{array}{l}\text { Configuração } \\
\text { da lesão. } \\
\text { Valor da } \\
\text { indenização. }\end{array}$ & Provido & 50.000 \\
\hline $\begin{array}{c}R R-105200- \\
70.2006 .5 .09 .0014\end{array}$ & $07 / 06 / 13$ & Feminino & $\begin{array}{l}\text { Assédio moral. } \\
\text { Insinuação } \\
\text { sobre } \\
\text { sexualidade. } \\
\text { Ofensas. }\end{array}$ & $\begin{array}{l}\text { Configuração } \\
\text { da lesão. } \\
\text { Valor da } \\
\text { indenização. }\end{array}$ & $\begin{array}{c}\text { Não } \\
\text { conhecido }\end{array}$ & 20.000 \\
\hline $\begin{array}{c}\text { RR - 334- } \\
20.2011 .5 .09 .0892\end{array}$ & $19 / 04 / 13$ & Masculino & $\begin{array}{c}\text { Dispensa } \\
\text { discriminatória. }\end{array}$ & $\begin{array}{c}\text { Configuração } \\
\text { da lesão. }\end{array}$ & Provido & $\begin{array}{c}\text { Sem } \\
\text { condenação }\end{array}$ \\
\hline $\begin{array}{c}\text { AIRR - 1704- } \\
55.2010 .5 .18 .0007\end{array}$ & $26 / 03 / 13$ & Masculino & $\begin{array}{c}\text { Assédio moral. } \\
\text { Humor } \\
\text { vexatório. }\end{array}$ & $\begin{array}{c}\text { Configuração } \\
\text { da lesão. } \\
\text { Valor da } \\
\text { indenização. }\end{array}$ & Desprovido & 5.000 \\
\hline $\begin{array}{c}\text { RR - 143900- } \\
52.2008 .5 .04 .0025\end{array}$ & $14 / 12 / 12$ & Feminino & $\begin{array}{l}\text { Assédio moral. } \\
\text { Insinuação } \\
\text { sobre } \\
\text { sexualidade. }\end{array}$ & $\begin{array}{c}\text { Configuração } \\
\text { da lesão. } \\
\text { Valor da } \\
\text { indenização. }\end{array}$ & $\begin{array}{c}\text { Não } \\
\text { conhecido }\end{array}$ & 5.000 \\
\hline $\begin{array}{c}\text { RR - 281540- } \\
92.2005 .5 .02 .0014\end{array}$ & $21 / 09 / 12$ & Masculino & $\begin{array}{l}\text { Humilhação. } \\
\text { Humor } \\
\text { vexatório. }\end{array}$ & $\begin{array}{c}\text { Configuração } \\
\text { da lesão. } \\
\text { Valor da } \\
\text { indenização. }\end{array}$ & Provido & 35.000 \\
\hline $\begin{array}{l}\text { AIRR - 2955840- } \\
41.2006 .5 .11 .0018\end{array}$ & $22 / 06 / 12$ & Masculino & $\begin{array}{c}\text { Humor } \\
\text { vexatório. } \\
\text { Insinuação } \\
\text { sobre } \\
\text { sexualidade. }\end{array}$ & $\begin{array}{l}\text { Configuração } \\
\text { da lesão. } \\
\text { Valor da } \\
\text { indenização. }\end{array}$ & Desprovido & 5.000 \\
\hline $\begin{array}{c}\text { AIRR - 64100- } \\
89.2010 .5 .17 .0009\end{array}$ & $25 / 05 / 12$ & Masculino & $\begin{array}{c}\text { Assédio moral. } \\
\text { Humor } \\
\text { vexatório. } \\
\text { Ofensas. } \\
\end{array}$ & $\begin{array}{c}\text { Configuração } \\
\text { da lesão. } \\
\text { Valor da } \\
\text { indenização. }\end{array}$ & Desprovido & 30.000 \\
\hline $\begin{array}{c}R R-128600- \\
30.2006 .5 .04 .0022\end{array}$ & 16/03/12 & Masculino & $\begin{array}{c}\text { Humor } \\
\text { vexatório. } \\
\text { Ofensas. }\end{array}$ & $\begin{array}{c}\text { Configuração } \\
\text { da lesão. }\end{array}$ & $\begin{array}{c}\text { Não } \\
\text { conhecido }\end{array}$ & 10.000 \\
\hline $\begin{array}{c}\text { AIRR - 74240- } \\
53.2002 .5 .02 .0019\end{array}$ & $18 / 02 / 11$ & Masculino & $\begin{array}{c}\text { Dispensa } \\
\text { discriminatória. } \\
\text { Ofensas. }\end{array}$ & $\begin{array}{c}\text { Configuração } \\
\text { da } \\
\text { discriminação. }\end{array}$ & Desprovido & $\begin{array}{l}50 \text { salários } \\
\text { mínimos }\end{array}$ \\
\hline $\begin{array}{c}\text { AIRR - 3404100- } \\
20.2002 .5 .21 .0900\end{array}$ & $05 / 02 / 10$ & Masculino & $\begin{array}{c}\text { Dispensa } \\
\text { discriminatória. }\end{array}$ & $\begin{array}{c}\text { Configuração } \\
\text { da }\end{array}$ & Desprovido & $\begin{array}{c}\text { Sem } \\
\text { informações }\end{array}$ \\
\hline
\end{tabular}




\begin{tabular}{|c|c|c|c|c|c|c|}
\hline $\begin{array}{l}\text { Número do } \\
\text { processo }\end{array}$ & $\begin{array}{c}\text { Data de } \\
\text { publicação }\end{array}$ & $\begin{array}{c}\text { Gênero do(a) } \\
\text { reclamante }\end{array}$ & $\begin{array}{c}\text { Discriminação } \\
\text { alegada }\end{array}$ & $\begin{array}{l}\text { Tema do } \\
\text { Recurso }\end{array}$ & Dispositivo & $\begin{array}{c}\text { Danos } \\
\text { morais ( } R \$)\end{array}$ \\
\hline & & & & $\begin{array}{l}\text { discriminação. } \\
\text { Reintegração } \\
\text { da L. } 9.029 .\end{array}$ & & \\
\hline $\begin{array}{c}R R-101900- \\
52.2004 .5 .05 .0024\end{array}$ & 09/10/09 & Masculino & $\begin{array}{l}\text { Dispensa } \\
\text { discriminatória. } \\
\text { Humilhação. } \\
\text { Ofensas. }\end{array}$ & $\begin{array}{c}\text { Configuração } \\
\text { da } \\
\text { discriminação. } \\
\text { Reparação da } \\
\text { L. 9.029. } \\
\text { Configuração } \\
\text { da lesão. } \\
\text { Valor da } \\
\text { indenização. }\end{array}$ & $\begin{array}{c}\text { Não } \\
\text { conhecido }\end{array}$ & $\begin{array}{c}200.000 \\
\text { (fixados em } \\
\text { conjunto) }\end{array}$ \\
\hline $\begin{array}{c}\text { RR - 130600- } \\
85.2007 .5 .20 .0001\end{array}$ & $15 / 05 / 09$ & Masculino & $\begin{array}{l}\text { Humilhação. } \\
\text { Humor } \\
\text { vexatório. } \\
\text { Insinuação } \\
\text { sobre } \\
\text { sexualidade. }\end{array}$ & $\begin{array}{l}\text { Configuração } \\
\text { da lesão. } \\
\text { Valor da } \\
\text { indenização. }\end{array}$ & $\begin{array}{c}\text { Não } \\
\text { conhecido }\end{array}$ & 5.000 \\
\hline $\begin{array}{l}\text { AIRR - 766340- } \\
12.2006 .5 .12 .0034\end{array}$ & $31 / 10 / 08$ & Feminino & $\begin{array}{c}\text { Dispensa } \\
\text { discriminatória. }\end{array}$ & $\begin{array}{l}\text { Cumulação de } \\
\text { indenização } \\
\text { com } \\
\text { reparação da } \\
\text { L. } 9.029 . \\
\end{array}$ & Desprovido & $\begin{array}{c}\text { Sem } \\
\text { informações }\end{array}$ \\
\hline $\begin{array}{c}\text { AIRR }-8440- \\
31.2005 .5 .01 .0042\end{array}$ & 09/05/08 & Feminino & $\begin{array}{l}\text { Discriminaçãa. } \\
\text { Preterição de } \\
\text { promoção. }\end{array}$ & $\begin{array}{c}\text { Configuração } \\
\text { da lesão. } \\
\text { Valor da } \\
\text { indenização. }\end{array}$ & Desprovido & 6.800 \\
\hline $\begin{array}{c}\text { AIRR - 55840- } \\
79.2004 .5 .09 .0001\end{array}$ & $22 / 06 / 07$ & Masculino & Discriminação. & $\begin{array}{l}\text { Configuração } \\
\text { da lesão. }\end{array}$ & Desprovido & $\begin{array}{c}\text { Sem } \\
\text { condenação }\end{array}$ \\
\hline $\begin{array}{l}\text { AIRR - 772540- } \\
71.2002 .5 .12 .0035\end{array}$ & 01/06/06 & Masculino & $\begin{array}{c}\text { Dispensa } \\
\text { discriminatória. } \\
\text { Humilhação. }\end{array}$ & $\begin{array}{c}\text { Configuração } \\
\text { da lesão. }\end{array}$ & Desprovido & $\begin{array}{c}\text { Sem } \\
\text { informações }\end{array}$ \\
\hline
\end{tabular}


ANEXO

Quadro 2. Estrutura das relações sociais de reconhecimento

\begin{tabular}{llll}
\hline $\begin{array}{l}\text { Modos de } \\
\text { reconhecimento }\end{array}$ & Dedicação emotiva & Respeito cognitivo & Estima social \\
\hline $\begin{array}{l}\text { Dimensões da } \\
\text { personalidade }\end{array}$ & $\begin{array}{l}\text { Natureza carencial } \\
\text { e afetiva }\end{array}$ & $\begin{array}{l}\text { Imputabilidade } \\
\text { moral }\end{array}$ & $\begin{array}{l}\text { Capacidades e } \\
\text { propriedades }\end{array}$ \\
\hline $\begin{array}{l}\text { Formas de } \\
\text { reconhecimento }\end{array}$ & $\begin{array}{l}\text { Relações } \\
\text { primárias (amor, } \\
\text { amizade) }\end{array}$ & $\begin{array}{l}\text { Relaçães jurídicas } \\
\text { (direitos) }\end{array}$ & $\begin{array}{l}\text { Comunidade de } \\
\text { valores } \\
\text { (solidariedade) }\end{array}$ \\
\hline Potencial evolutivo & & $\begin{array}{l}\text { Generalização, } \\
\text { materialização }\end{array}$ & $\begin{array}{l}\text { Individualização, } \\
\text { igualização }\end{array}$ \\
\hline $\begin{array}{l}\text { Autorrelação } \\
\text { prática }\end{array}$ & Autoconfiança & Autorrespeito & Autoestima \\
\hline $\begin{array}{l}\text { Formas de } \\
\text { desrespeito }\end{array}$ & $\begin{array}{l}\text { Maus-tratos e } \\
\text { violação }\end{array}$ & $\begin{array}{l}\text { Privação de } \\
\text { direitos e exclusão }\end{array}$ & $\begin{array}{l}\text { Degradação e } \\
\text { ofensa }\end{array}$ \\
\hline $\begin{array}{l}\text { Componentes } \\
\text { ameaçados da } \\
\text { personalidade }\end{array}$ & Integridade física & Integridade social & "Honra", dignidade \\
\hline
\end{tabular}

Fonte: HONNETH, Axel. Luta por reconhecimento: a gramática moral dos conflitos sociais. São Paulo: Ed. 34, 2003, p. 211. 